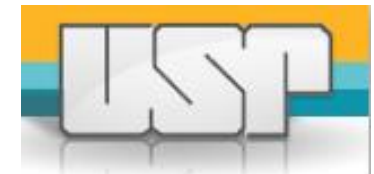

UNIVERSIDADE DE SÃO PAULO

Faculdade de Filosofia, Letras e Ciências Humanas

Departamento de Geografia

Programa de Pós-Graduação em Geografia Física

Tulius Dias Nery

Dinâmica das corridas de detritos no Litoral Norte de São Paulo

Edição Revisada

São Paulo

2016 
Tulius Dias Nery

\section{Dinâmica das corridas de detritos no Litoral Norte de São Paulo}

Tese apresentada ao Programa de PósGraduação em Geografia Física, Departamento de Geografia da Faculdade de Filosofia, Letras e Ciências Humanas da Universidade de São Paulo como requisito para obtenção do título de Doutor.

Orientadora: Profa. Dra. Bianca Carvalho Vieira

Área de concentração: Geografia Física Linha de pesquisa: Estudos interdisciplinares em Pedologia e Geomorfologia.

\section{Edição Revisada}

São Paulo

2016 
Dinâmica das corridas de detritos no Litoral Norte de São Paulo

Tese apresentada ao Programa de PósGraduação em Geografia Física, Departamento de Geografia da Faculdade de Filosofia, Letras e Ciências Humanas da Universidade de São Paulo como requisito para obtenção do título de Doutor.

\section{Banca Examinadora}

Profa. Dra. Bianca Carvalho Vieira (orientadora)

Depto. de Geografia - Universidade de São Paulo

\section{Prof. Dr. Claudinei Taborda da Silveira}

Depto. de Geografia - Universidade Federal do Paraná

Prof. Dr. Marcio Roberto Magalhães de Andrade

Centro Nacional de Monitoramento e Alertas de Desastres Naturais - Cemaden

Prof. Dr. Fernando Nadal Junqueira Villela

Depto. de Geografia - Universidade de São Paulo

Prof. Dr. Jurandyr Luciano Sanches Ross

Depto. de Geografia - Universidade de São Paulo 
Autorizo a reprodução e divulgação total ou parcial deste trabalho, por qualquer meio convencional ou eletrônico, para fins de estudo e pesquisa, desde que citada a fonte.

\section{FICHA CATALOGRÁFICA}

Catalogação na Publicação

Serviço de Biblioteca e Documentação

Faculdade de Filosofia, Letras e Ciências Humanas da Universidade de São Paulo.

Nery, Tulius Dias

Dinâmica das corridas de detritos no Litoral Norte de São Paulo/Tulius Dias Nery; orientadora: Bianca Carvalho Vieira - São Paulo, 2015. $164 \mathrm{f}$.

Tese (Doutorado) - Faculdade de Filosofia, Letras e Ciências Humanas da Universidade de São Paulo. Departamento de Geografia. Área de concentração: Geografia Física.

1. Gemorfologia. 2. Corridas de detritos. 3. Parâmetros morfométricos. 4. Modelos empíricos. 5. Potencial de geração de corridas de detritos.

I. Vieira, Bianca Carvalho. II. Universidade de São Paulo - Programa de Pós-Graduação em Geografia Física. III. Título de Doutor. 
Dedico este trabalho a minha mãe, minha madrinha e Carol, minha companheira por todo apoio, carinho e compreensão. 


\section{AGRADECIMENTOS}

Passados quatro anos eis que concluo mais um ciclo acadêmico. Mais um ciclo da minha vida, ciclo este vivenciado por muito aprendizado, crescimento pessoal e profissional.

Gostaria de agradecer, em primeiro lugar, a minha orientadora, Bianca C. Vieira que me incentivou e ensinou a trilhar o caminho da carreira científica, instigando-me a buscar sempre uma melhor compreensão dos fatos, uma melhor abordagem no desenvolvimento do pensar. Foi esse ensinar que nos proporcionou alcançar, ao longo do doutorado, a indicação de dissertação pelo Projeto USP Rio+20 na área de Agenda 21 e governança (2012).

O reconhecimento e a confirmação do rumo da minha carreira científica e, por que não dizer profissional, veio por meio do apoio financeiro concedido pela International Association of Geomorphologist (IAG) para participação no Geomorphology 2013.

Agradeço a todos os funcionários do Programa de Pós-Graduação em Geografia Física do Departamento de Geografia pelos auxílios prestados ao longo desta jornada.

Agradeço a contribuição da banca examinadora de qualificação e examinadora de defesa, pelo aceite e disponibilidade despendida.

Sei que, ou melhor, sabemos que esta trajetória não foi fácil, mas valeu a pena cada momento, cada campo, o esforço e a dedicação de cada um. Agradeço a minha família, por compreender a minha ausência, por me apoiar e por não me deixarem desistir, mesmo estando distante. Por acreditarem, por me mostrarem que sou capaz de realizar e conquistar os meus objetivos, mesmo quando eu já acreditava que a causa estava perdida.

Ao grupo de pesquisa por todos estes anos de trabalhos: Fabrizio, Luzia, Maria Carolina e Vivian. Pelo aprendizado e crescimento pessoal de cada um. Desejo sucesso em suas vidas!

Agradeço também, as pessoas que contribuíram de forma direta e indireta no desenvolvimento desta pesquisa, auxiliando em minhas dúvidas e questionamentos que enriqueceram as discussões ao longo da sua construção: A. Ogura, Carol Paiva, Claudinei T. Silveira, M. Gramani, M. Kanji, M. B. Firmino, Nelson F. Fernandes, Regla Somoza, Roberto T. Gomes, Rodrigo Conceição, Rodrigo Stabile, Vanessa Canavesi e Viviane Portela.

Aos entes que deixei em São Paulo, um abraço e saibam que tirei o melhor de cada um de vocês. Aos amigos e colegas que conquistei e reencontrei na passagem por Cachoeira Paulista e São José dos Campos, minha nova morada.

Aos entes do Cemaden pela convivência dentro e fora do ambiente de trabalho. Aos amigos da Mansão Bravo pela convivência, conversas e descontração ao longo deste ano.

Muito obrigado a todos! 


\section{RESUMO}

NERY, T.D. Dinâmica das corridas de detritos no Litoral Norte de São Paulo. 2016. 164. Tese (Doutorado) - Faculdade de Filosofia, Letras e Ciências Humanas, Universidade de São Paulo, São Paulo, 2016.

As corridas de detritos são processos caracterizados por escoamentos rápidos associados a precipitações intensas e/ou acumuladas. A ocorrência destes processos está associada a diversas variáveis do meio físico e quando associadas a eventos extremos de precipitação podem gerar grande volume de sedimentos como aqueles observados em 1967 no município de Caraguatatuba (SP). Neste contexto, o objetivo desta pesquisa foi avaliar o potencial de geração de corridas de detritos a partir do emprego de parâmetros morfométricos para as bacias hidrográficas dos rios Santo Antônio, Guaxinduba e Mococa. Metodologicamente, o trabalho dividiu-se, em um primeiro momento, na identificação dos escorregamentos e das zonas de arraste e deposição das corridas de detritos. Posteriormente, foram extraídos os parâmetros e os índices morfométricos das bacias (área, amplitude, comprimento do canal, ângulo da encosta, índice de circularidade, densidade de drenagem e declividade média do canal), e analisados de forma qualitativa e quantitativa. A partir do reconhecimento dos processos foram selecionadas as sub-bacias para a aplicação de dois modelos empíricos considerando os valores de concentração de sólidos e de precipitação. Assim, por meio dos cenários propostos de $60 \mathrm{~mm} / \mathrm{h}$ e $100 \mathrm{~mm} / \mathrm{h}$ e concentração de sólidos de $50 \%$ foram obtidos os valores de vazão e de volume de sedimentos das corridas de detritos para cada sub-bacia selecionada. Os resultados obtidos na análise qualitativa mostraram similaridades entre as bacias dos rios Santo Antônio e Mococa, fato este não observado para a bacia do Guaxinduba. No entanto, a bacia do Guaxinduba apresentou maior potencial para a geração de corridas de detritos. Em 40 sub-bacias, observou-se que houve diferença de aproximadamente $60 \%$ da vazão e volume em relação aos cenários de $60 \mathrm{~mm} / \mathrm{h}$ e $100 \mathrm{~mm} / \mathrm{h}$. Além disso, observou-se nas formulações empregadas que a inserção de variáveis geram valores distintos de vazão de pico e volume de sedimentos. Identificou-se que a bacia do Guaxinduba apresentou maior potência, porém com volumes inferiores aos observados nas bacias do Santo Antônio e Mococa. Acreditase que a combinação destes métodos pode auxiliar na identificação de áreas suscetíveis à ocorrência das corridas de detritos em regiões serranas, como o Litoral Norte de São Paulo.

Palavras-chave: Geomorfologia; Corridas de detritos; Parâmetros morfométricos; Modelos empíricos; Potencial de geração de corridas de detritos. 


\begin{abstract}
NERY, T.D. Dynamics of debris flow in the north coast of São Paulo. 2016. 164. Thesis (Doctoral) - Faculdade de Filosofia, Letras e Ciências Humanas, Universidade de São Paulo, São Paulo, 2016.

Debris flow processes are characterized by rapid runoff associated with heavy and/or accumulated rainfall. The occurrence of these processes is associated with several variables of the physical environment and when associated with extreme precipitation events can generate large amounts of sediment as those observed in 1967 in the city of Caraguatatuba (SP). In this context, the objective of this research was to evaluate the potential of generating debris flow from the use of morphometric parameters for the river basins of the Santo Antonio, Guaxinduba and Mococa. Methodologically, the work was divided, at first, the identification of landslides and areas of deposition of debris flow. Subsequently, the parameters and morphometric indices of the basins were extracted (area, basin relief, channel length, slope angle, circularity ratio, drainage density and average channel slope), and analyzed qualitatively and quantitatively. Based the recognition of the processes the sub-basins to the application of two empirical models considering the solid concentration values and precipitation were selected. Thus by the proposed scenarios of $60 \mathrm{~mm} / \mathrm{h}$ and 100 $\mathrm{mm} / \mathrm{h}$ solids concentration of $50 \%$ were obtained the values of peak discharges and magnitude of debris flow for each selected sub-basin. The results of the qualitative analysis showed similitarities between the rivers basins of the Santo Antônio and Mococa, which is not observed for the basin Guaxinduba. However, the basin Guaxinduba showed greater potential for the generation of debris flow. In sub-basin 40 , it was observed that there was a difference of approximately $60 \%$ of peak discharges and magnitude in relation to the scenarios of $60 \mathrm{~mm} / \mathrm{h}$ and $100 \mathrm{~mm} / \mathrm{h}$. Furthermore, it was observed that the formulations employed in the insertion variables generate different peak and magnitude values of sediment. It was identified that the Guaxinduba basin showed a higher power, but with magnitude lower than those observed in the basins of Santo Antônio and Mococa. It is believed that the combination of these methods can help identify areas susceptible to the occurrence of debris flow in mountainous regions such as the North Coast of São Paulo.
\end{abstract}

Keywords: Geomorphology; Debris flows; Morphometric parameters; Empirical models; Susceptibility. 


\section{LISTA DE FIGURAS}

Figura 1: Escorregamentos e corridas de detritos em diferentes localidades das regiões serranas do Brasil. Os processos ocorreram de forma pontual e/ou generalizados, iniciando próximos aos divisores, alcançando a rede de drenagem, deslocando-se e ocupando as áreas mais planas das bacias. Fonte das imagens: (a) www.vitruvius.com.br; (b) Associação Brasileira de Mecânica dos Solos e Engenharia Geotécnica (c) Instituto de Pesquisas Tecnológicas; (d) Instituto Geológico; (e) O Globo; (f) Arquivo pessoal: Tulius Dias Nery.

Figura 2: Escorregamentos na Serra do Mar, em Cubatão, em 1985. Diversos escorregamentos (setas em amarelo) forneceram materiais incorporados ao canal de drenagem, aumentando o volume sedimentar das corridas de detritos (setas em vermelho). Fonte: IPT.

Figura 3: Depósitos de blocos na linha de drenagem (setas vermelhas) e possíveis depósitos pretéritos (linha tracejada amarela), exumados pela passagem da corrida de detritos de 2011. Observar o imbricamento dos clastos de tamanho variado e posicionados, em sua maior parte, para uma mesma direção (setas laranjas), envolto por uma matriz fina de sedimentos. Afluente do córrego do Cuiabá, Petrópolis-RJ. Fonte: Tulius Dias Nery, 2011.

Figura 4: Perfil esquemático da declividade do canal. A zona inicial corresponde às áreas com declividades superiores a $25^{\circ}$; a zona de transporte e erosão associa-se com as áreas de declividades maiores que $15^{\circ}$; a zona de deposição parcial, em forma de dique, ocorre geralmente em declividades inferiores a $15^{\circ}$; e a deposição do material ocorre abaixo de $10^{\circ}$ (modificado de VANDINE, 1996).

Figura 5: Depósitos da corrida de detritos em uma seção mais plana do córrego do Príncipe, bairro da Posse, Teresópolis (RJ). Observar o tamanho (diâmetro) dos sedimentos.

Figura 6: Geometria da corrida de detrito (modificado de Kobiyama et al., 2010).

Figura 7: Cicatrizes de escorregamentos e de corridas de detritos deflagrados na bacia do rio Mococa. Na fotografia aérea (a), diferentes setores das encostas foram afetados por estes processos, apresentando geometrias variáveis. Na ortofoto (b) é possível identificar (setas vermelhas) as encostas onde ocorreram os escorregamentos 1967

. .36

Figura 8: Observa-se que alguns processos ocorreram nos divisores da bacia e sub-bacias (linha tracejada amarela). Chama-se atenção para a diferença de tonalidade e de geometria permitindo a sua identificação na fotografia aérea (seta vermelha).

Figura 9: llustração do método usado para o cálculo de sedimentos por meio de fotografias aéreas. Fonte: Adaptado de Cannon, 1989.

Figura 10: Perfil topográfico elaborado por meio do MDT, entre os municípios de Natividade da Serra e Caraguatatuba, em São Paulo, perfazendo uma secção da bacia do rio Santo Antônio.

Figura 11: Mapa de isoietas para o evento de 1967. Os maiores valores de precipitação ocorreram sobre as bacias dos rios Santo Antônio e Mococa. Fonte dos dados: HidroWeb - ANA e Cepagri Unicamp.

Figura 12: Cicatrizes de escorregamentos nas encostas da Serra do Mar, que atingiram a rodovia dos Tamoios (setas vermelhas) interrompendo a circulação de veículos em determinados trechos. Fonte: Cruz (1974).

Figura 13: Arranjo e deposição dos blocos de tamanhos variados (setas amarelas) sobre as margens do canal (setas vermelhas). A seta azul indica a localização do rio. Fonte: Cruz (1974).

Figura 14: Deposição de entulhos, troncos e galhos de árvores (setas vermelhas) na planície da bacia. A altura da coluna da corrida de detritos pode ser observada pela seta amarela, indicando a magnitude do evento. Fonte: Arquivo Público do município de Caraguatatuba.

Figura 15: Casas destruídas pela passagem do fluxo de água. Cicatrizes de escorregamentos nas encostas da Serra do Mar (setas amarelas) (a). Observa-se que as casas serviram de barragem para a água e para os materiais transportados pela corrida de detritos (b). Fonte: Arquivo Público do município de Caraguatatuba. 
Figura 16: Mapa de localização das bacias dos rios Santo Antônio, Guaxinduba e Mococa, em Caraguatatuba-SP.

Figura 17: Fluxograma das etapas metodológicas da pesquisa.

Figura 18: Identificação e delimitação das cicatrizes dos escorregamentos (a). Pontos gerados a partir da conversão do limite de cada cicatriz (b). Tais informações foram utilizadas para estimar o volume e a densidade de escorregamento por bacia e sub-bacia.

Figura 19: A identificação das cicatrizes na fotografia aérea (a) foi prejudicada pela presença de sombras na ortofoto (b), dificultando a sua delimitação, visto que a ortofoto serviu como referência para o georreferenciamento da fotografia aérea.

58

Figura 20: Mosaico das imagens utilizadas para o reconhecimento dos depósitos ou zona de arraste: (a) mapa geomorfológico (Cruz, 1972); (b) fotografia aérea (IPT, 1973); (c) ortofoto (Emplasa, 2010/2011); (d) sobreposição dos depósitos obtidos por meio da carta geomorfológica; e (e) sobreposição dos depósitos ou zonas de arraste obtido via fotografia aérea. As setas (em preto) indicam a localização dos depósitos mapeados e observados nas imagens (a e b).

Figura 21: Encosta com presença de blocos próximos a um afluente do rio Guaxinduba (a). Medição do diâmetro dos blocos depositados em um determinado trecho nas margens do rio Guaxinduba (b). Fonte: Vivian C. Dias.

Figura 22: Fluxograma do procedimento de extração dos parâmetros no TerraHidro. 66

Figura 23: Esquema para determinação do fluxo contínuo, método D8: direções possíveis de um pixel (a); atribuição de códigos de direção para cada célula em volta da célula central (b; direção do escoamento para cada célula de menor cota. Fonte: Bosquilia et al. (2013).

Figura 24: (a) Modelo Digital; (b) Direção de fluxo; (c) Área acumulada; e (d) rede de drenagem, bacia e sub-bacias.

Figura 25: Mapa das bacias e suas respectivas sub-bacias selecionadas para as análises qualitativa e quantitativa: Santo Antônio (a), Guaxinduba (b) e Mococa (c). Os critérios adotados para a seleção destas sub-bacias foi a ocorrência de escorregamentos e/ou corridas de detritos. .................................72

Figura 26: Mapa de cicatrizes das bacias dos rios Santo Antônio e Guaxinduba.................................... 79

Figura 27: Mapa de cicatriz da bacia do rio Mococa.

Figura 28: Gráfico apresentando a contribuição de sedimentos por área da cicatriz. Observa-se a predominância de áreas de cicatrizes entre 5000 e $30000 \mathrm{~m}^{2}$, representando valores acima de 60\%: Mococa (60\%), Guaxinduba (62\%) e Santo Antônio (79\%). Cicatrizes com áreas inferiores a 1000 contribuem com menos de $1,5 \%$.

Figura 29: Mapa dos depósitos da bacia do rio Santo Antônio. .85

Figura 30: Blocos de tamanhos variados em um afluente do rio Santo Antônio com diâmetros de até de $5 \mathrm{~m}$ (a). A passagem da corrida exumou os depósitos mais antigos compostos, na maior parte, por blocos de diâmetros menores (b). Fonte: Olga Cruz.

Figura 31: Depósitos de sedimentos grosseiros ao longo do rio Santo Antônio. Local próximo ao estrangulamento da drenagem, que contribui para o acúmulo destes sedimentos, como observado por Cruz (1974). Fonte: Arquivo do Parque Estadual da Serra do Mar - Núcleo Caraguatatuba..........87

Figura 32: Bacia do rio Santo Antônio. Cicatrizes dos escorregamentos de 1967 no Morro do Tinga (a) e a planície do rio ocupada pelos sedimentos menos grosseiros das corridas de detritos (b). Observam-se troncos de árvores trazidos das partes mais altas (a), bem como o alargamento do rio demostrando a magnitude do evento (b). Fonte: Arquivo Público do município de Caraguatatuba. .... 88

Figura 33: Mapa dos depósitos da bacia do rio Guaxinduba.

Figura 34: Imagem panorâmica de um afluente da margem direita do rio Guaxinduba e a distribuição dos depósitos em uma seção da sub-bacia (setas em vermelho indicam a localização das fotos subsequentes) (a). Depósitos de diâmetros variados localizados na encosta (depósito de tálus) e próximos à rede de drenagem (setas amarelas) (b). Depósitos expostos apresentando a disposição 
dos blocos de tamanhos variados (setas amarelas) (c). Blocos de diâmetros menores depositados no leito do canal (seta amarela). Fonte: Bianca C. Vieira............................................................................ 91

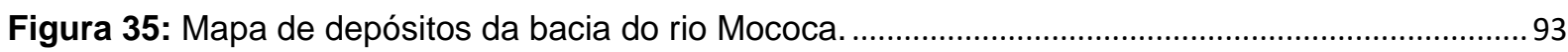

Figura 36: Depósitos de sedimentos grosseiros ao longo do rio Mococa próximo à região de escarpa ( $a$ e b). Trecho do rio Mococa próximo ao residencial Mar Verde, demonstrando a ausência aparente, de sedimentos mais grosseiros (c e d). Fonte: Panoramio

Figura 37: Volume de sedimentos para as bacias analisadas. Os valores observados indicam a magnitude do evento para a bacia do Santo Antônio. Inversamente, a bacia do Mococa apresentou valores de sedimentos próximos aos valores observados para a bacia do Guaxinduba. 95

Figura 38: Mapa de declividade das bacias dos rios Santo Antônio (a), Guaxinduba (b) e Mococa (c).

Figura 39: Gráfico apresentando a distribuição dos escorregamentos em relação às classes de declividades. Os escorregamentos concentraram-se entre os intervalos de 15 a $45^{\circ}$, com o potencial de escorregamento entre as classes de 15 a $60^{\circ}$. 104

Figura 40: Mapa de localização e identificação das sub-bacias dos rios Santo Antônio e Mococa para análise qualitativa das corridas de detritos.

Figura 41: Gráfico de vazão de pico em função do volume de sedimentos para os cenários de 60 $\mathrm{mm} / \mathrm{h}$ (a) e $100 \mathrm{~mm} / \mathrm{h}$ (b). Observou-se que com o aumento da área da bacia há o aumento da vazão de pico e consequentemente, o aumento do volume de sedimentos para as sub-bacias do rio Santo Antônio.

Figura 42: Gráfico de vazão de pico em função do volume de sedimentos para os cenários de 60 $\mathrm{mm} / \mathrm{h}$ (a) e $100 \mathrm{~mm} / \mathrm{h}$ (b). Observou-se que com o aumento da área da bacia há o aumento da vazão de pico e consequentemente, o aumento do volume de sedimentos para as sub-bacias do rio Guaxinduba.

Figura 43: Gráfico de vazão de pico em função do volume de sedimentos para os cenários de 60 $\mathrm{mm} / \mathrm{h}$ (a) e $100 \mathrm{~mm} / \mathrm{h}$ (b). Observou-se que com o aumento da área da bacia há o aumento da vazão de pico e consequentemente, o aumento do volume de sedimentos para as sub-bacias do rio Mococa.

Figura 44: Localização e identificação das sub-bacias do rio Guaxinduba, destacando as sub-bacias com áreas inferiores a $0,30 \mathrm{~km}^{2}(42,29,40,37,46,18,38,58,63,27,36,19,32$ e 39) e que geraram baixos valores de vazão de pico.

Figura 45: Gráfico de volume total de sedimentos. Observa-se que há uma tendência de aumento do volume em função da área da bacia. Entre os cenários (a) e (b) este aumento de volume foi de $60 \%$.

120

Figura 46: Gráfico de volume total de sedimentos. Observa-se que áreas inferiores a $1 \mathrm{~km}^{2}$ apresentaram comportamento similar para ambos os cenários (a) e (b). O modelo de Araya Moya (1994) apresentou-se mais sensível para esta bacia, podendo indicar maior influência da amplitude nestas sub-bacias.

Figura 47: Gráfico de volume total de sedimentos. Observa-se comportamento distinto, em ambos os cenários (a) e (b), em relação aos modelos adotados. Para sub-bacias entre 0,1 a 1,9 km o modelo de Araya Moya (1994) foi mais sensível; enquanto para sub-bacias entre 2,3 a 4,1 km² o modelo mais sensível foi o de Massad et al. (1997).

Figura 48: Gráfico de volume de sedimentos (cicatrizes e depósitos) em função dos modelos empíricos para bacias do Mococa (a) e Santo Antônio (b). Os resultados obtidos mostraram por meio das cicatrizes e depósitos que estes representaram até 30\% do volume gerado quando comparados com as formulações. 126

Figura 49: Mapa de potencial de geração de corridas de detritos para as sub-bacias do rio Santo Antônio. Figuras (a) e (b) representam os cenários de $60 \mathrm{~mm} / \mathrm{h}$ e $100 \mathrm{~mm} / \mathrm{h}$ para o modelo de 
Massad et al. (1997); (c) e (d) representam os cenários de $60 \mathrm{~mm} / \mathrm{h}$ e $100 \mathrm{~mm} / \mathrm{h}$ para o modelo de Araya Moya (1994).

Figura 50: Mapa de potencial de geração de corridas de detritos para as sub-bacias do rio Guaxinduba. Figuras (a) e (b) representam os cenários de $60 \mathrm{~mm} / \mathrm{h}$ e $100 \mathrm{~mm} / \mathrm{h}$ para o modelo de Massad et al. (1997); (c) e (d) representam os cenários de $60 \mathrm{~mm} / \mathrm{h}$ e $100 \mathrm{~mm} / \mathrm{h}$ para o modelo de Araya Moya (1994). 132

Figura 51: Mapa de potencial de geração de corridas de detritos para as sub-bacias do rio Mococa. Figuras (a) e (b) representam os cenários de $60 \mathrm{~mm} / \mathrm{h}$ e $100 \mathrm{~mm} / \mathrm{h}$ para o modelo de Massad et al. (1997); (c) e (d) representam os cenários de $60 \mathrm{~mm} / \mathrm{h}$ e $100 \mathrm{~mm} / \mathrm{h}$ para o modelo de Araya Moya (1994). 


\section{LISTA DE TABELA}

Tabela 1: Casos brasileiros de corridas de detritos 26

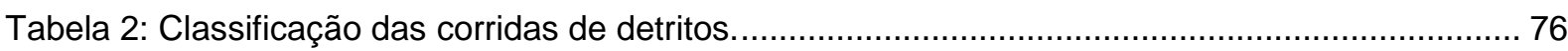

Tabela 3: Parâmetros e índices morfométricos e morfológicos das bacias. .....................................97

Tabela 4: Parâmetros e índices das sub-bacias do rio Santo Antônio ......................................... 106

Tabela 5: Parâmetros e índices das sub-bacias do rio Mococa. .................................................. 106

\section{LISTA DE QUADROS}

Quadro 1: Par. e crit. adotados para determinar o potencial de geração de corridas 71

Quadro 2: Informações para obtenção das estimativas de vazão de pico e magnitude..................74

Quadro 3: Correlação entre as classes de Jakob (2005) e Nery (2015) ....................................130

\section{LISTA DE EQUAÇÕES}

Equação 1 - Vazão de pico (Araya Moya) 29

Equação 2 - Vazão de Pico (Massad et al.) 29

Equação 3 - Vazão de Pico (Araya Moya modificada) 29

Equação 4 - Vazão de Pico (Rickennman) 30

Equação 5 - Vazão de Pico (Rickennman) 30

Equação 6 - Magnitude (Rickennman) 30

Equação 7 - Volume (Helsen et al.) 31

$\begin{array}{ll}\text { Equação } 8 \text { - Volume total (Takahashi) } & 31\end{array}$

Equação 9 - Volume (Fannin e Rollerson) 32

Equação 10 - Volume (Corominas) 32

Equação 11 - Volume (Rickennman)

Equação 12 - Volume (Kobiyama et al.) 33

Equação 13 - Relação de bifurcação (Hajam et al.) 41

Equação 14 - Gradiente de Canal (Christofoletti) 41

Equação 15 - Índice de sinuosidade (Schumm) 42

Equação 16 - Índice de força do canal (Moore et al.) 42

Equação 17- Densidade de drenagem (Horton) 43

Equação 18 - Frequência de drenagem (Horton) 43

Equação 19 - Índice de circularidade (Rogelis e Wener) 44

Equação 20 - Coeficiente de manutenção (Schumm) 44 
Equação 21 - Relação de relevo (Schumm)

Equação 22 - Altura e Distância (Corominas)

Equação 23 - Índice de umidade topográfica (Beven e Kirkby)

Equação 24 - Volume da cicatriz 59

Equação 25 - Volume do depósito

\section{LISTA DE SÍMBOLOS}

$A=$ Área da bacia ou sub-bacia

$A c=$ Área do círculo de perímetro igual ao da bacia

$A_{c}=$ Área da cicatriz

$A_{d}=$ Área do depósito

$a_{\text {máx }}=$ Altitude máxima

$A_{\text {fresh }}=$ Área do depósito recente

$A_{\text {old }}=$ Área do depósito pretérito

$A_{s}=$ Área específica da bacia

$c=$ Concentração de sólidos

$C_{m}=$ Coeficiente de manutenção

$D_{d}=$ Densidade de drenagem

$d_{v}=$ Comprimento vetorial entre os extremos do canal

$D=$ Distância horizontal

$D_{r}=$ Densidade de rios

$F_{S}=$ Frequência de drenagem

$G_{c}=$ Gradiente do canal

$H=$ Amplitude $(\mathrm{m})$

$I$ = Intensidade média de precipitação

$I_{1}=$ Intensidade de precipitação

$I_{c}=$ Índice de circularidade

$I_{s}=$ Índice de sinuosidade

$L=$ Comprimento total do rio/canal

$L=$ Distância da escarpa principal em relação ao depósito final

$l=$ Comprimento da área de deposição

$L_{t}=$ Comprimento total dos canais

$M_{*}=$ Magnitude

$N=$ Número total de rios

$N_{U}=$ Número total de canais de uma determinada ordem

$N_{U+1}=$ Número totatl dos canais de prdem imediatamente superior

$q_{t}=$ Vazão de pico 
$Q_{*}=$ Vazão de pico

$R_{b}=$ Relação de bifurcação

$R_{r}=$ Relação de relevo

$V=$ Volume

$V_{c}=$ Volume da cicatriz

$V_{d}=$ Volume do depósito

$V_{d}=$ Volume do material sedimentar observado na área terminal do depósito

$V_{\text {fresh }}=$ Volume do depósito recente

$V_{\text {Debris }}=$ Volume total do movimento de massa das corridas de detritos

$V_{\text {Debris } 1}$ e $V_{\text {Debris } 2}=$ volume do movimento inicial

$V_{\text {old }}=$ Volume do depósito pretérito

$V_{t}=$ Volume total

$\Delta a=$ Amplitude altimétrica

\section{LISTA DE ABREVIAÇÕES}

CPRM - Serviço Geológico do Brasil

EMPLASA - Empresa Paulista de Planejamento Metropolitano S/A

IG - Instituto Geológico

IPT - Instituto de Pesquisas Tecnológicas

MDT - Modelo Digital de Terreno

SIG's - Sistema de Informações Geográficas 


\section{SUMÁRIO}

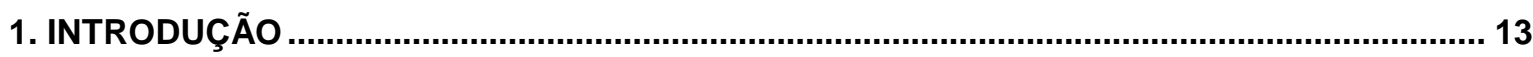

1.1 Hipótese e Objetivos ................................................................................................ 17

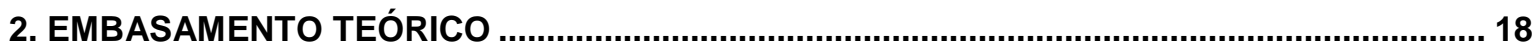

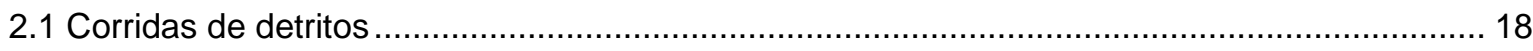

2.2 Estudos de caso sobre corridas de detritos no Brasil ................................................................ 25

2.3. Relações empíricas das corridas de detritos ................................................................ 28

2.4 Mapeamentos das feições (Cicatrizes e Depósitos) ……………………………………….... 35

2.5. Parâmetros morfométricos e avaliação das corridas de detritos .............................................. 40

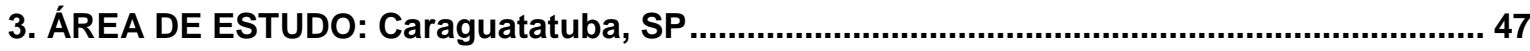

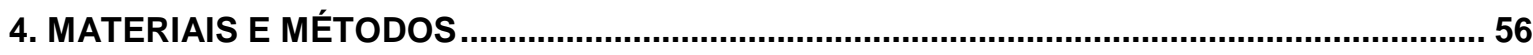

4.1 Identificação das áreas fonte nas encostas ...................................................................... 57

4.2 Identificação dos depósitos de corridas de detritos ........................................................ 60

4.3 Identificação dos parâmetros e índices morfométricos das bacias ........................................... 65

4.4 Hierarquização das bacias conforme os índices e a magnitude das corridas de detritos ......... 70

4.5 Análise quantitativa do potencial de geração das corridas de detritos ....................................... 73

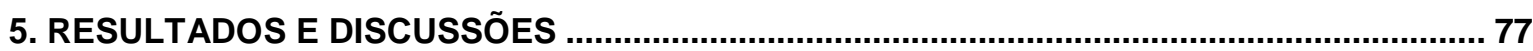

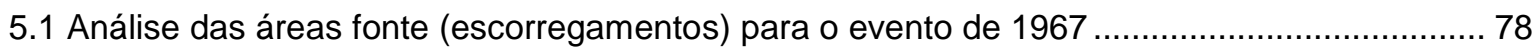

5.2 Reconhecimento das áreas de deposição das corridas de detritos ......................................... 84

5.3 Identificação dos parâmetros e índices morfométricos e morfológico das bacias ..................... 97

5.4 Análise comparativa das bacias do Santo Antônio e Mococa ……………………………..... 106

5.5 Hierarquização das bacias: potencial de corridas de detritos ............................................... 111

5.6 Classificação quanto à magnitude do evento ..................................................................... 129

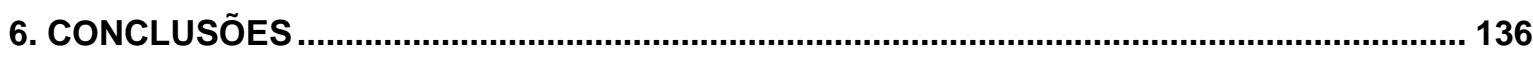

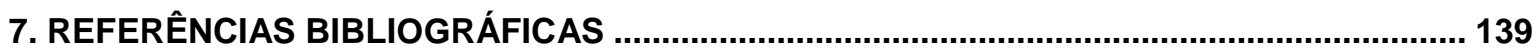

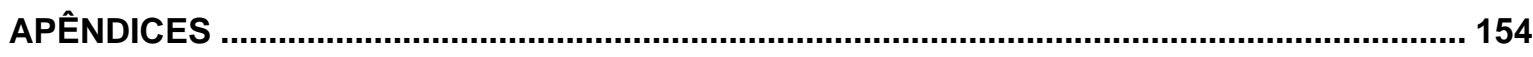

Apêndice 1: Número de escorregamentos e volume de sedimentos $\left(\mathrm{m}^{3}\right)$................................. 154

Apêndice 2: Parâmetros e índices das sub-bacias do rio Guaxinduba ........................................ 157

Apêndice 3: Parâmetros e modelos empíricos da vazão de pico e do volume total de sedimentos para as sub-bacias do rio Santo Antônio. …………………………………………………..... 158

Apêndice 4: Parâmetros e modelos empíricos da vazão de pico e do volume total de sedimentos para as sub-bacias do rio Guaxinduba................................................................................... 159

Apêndice 5: Parâmetros e modelos empíricos da vazão de pico e do volume total de sedimentos para as sub-bacias do rio Mococa. 160 


\section{INTRODUÇÃO}

Os movimentos de massa são processos modeladores da paisagem e ocorrem em regiões íngremes e montanhosas no mundo todo (SIDLE et al., 1985). No Brasil, a ocorrência destes processos, em sua maior parte, ocorre no compartimento Geológico-Geomorfológico da Serra do Mar, que se estende entre os estados do Rio de Janeiro e Santa Catarina.

Entre o período de 1928 e 2011, 3.637 pessoas morreram decorrentes dos movimentos de massa (BINI, 2012). Entre os movimentos de massa, destacam-se os escorregamentos, muito comumente observados na Serra do Mar e, de forma menos frequente, porém de grande magnitude, as corridas de detritos.

As corridas de detritos são processos naturais que estão condicionados a fatores geológicos, geomorfológicos e climáticos, associados a ambientes montanhosos. São processos de escoamento rápido, que envolvem grande volume de água, suficiente para deslocar os sedimentos de dimensões variadas, ao longo de sua trajetória (TAKAHASHI, 1981), percorrendo grandes distâncias, mesmo em regiões mais suaves do relevo (IPT, 1987; GRAMANI, 2001). A deflagração destes processos está associada à precipitação acumulada e a sua intensidade podendo variar em poucos minutos (4,9 a 17,4 mm/10 min) ou em poucas horas (20 a 30 mm/1h) (JONES, 1973; CAMPBELL, 1975; CAINE, 1980; WIECZOREK, 1987; ANDERSON e SITAR, 1995; KANJI et al., 2003; PELFINI e SANTILLI, 2008; FLORIS et al., 2010).

Em âmbito nacional, evidências sobre a ocorrência das corridas de detritos datam do século XX (KOBIYAMA e MICHEL, 2014), e como consequência, tais eventos causaram danos irreparáveis e inestimáveis perdas de vida (IPT, 1987, KANJI et al., 2003; KOBIYAMA et al., 2010) (Figura 1). 


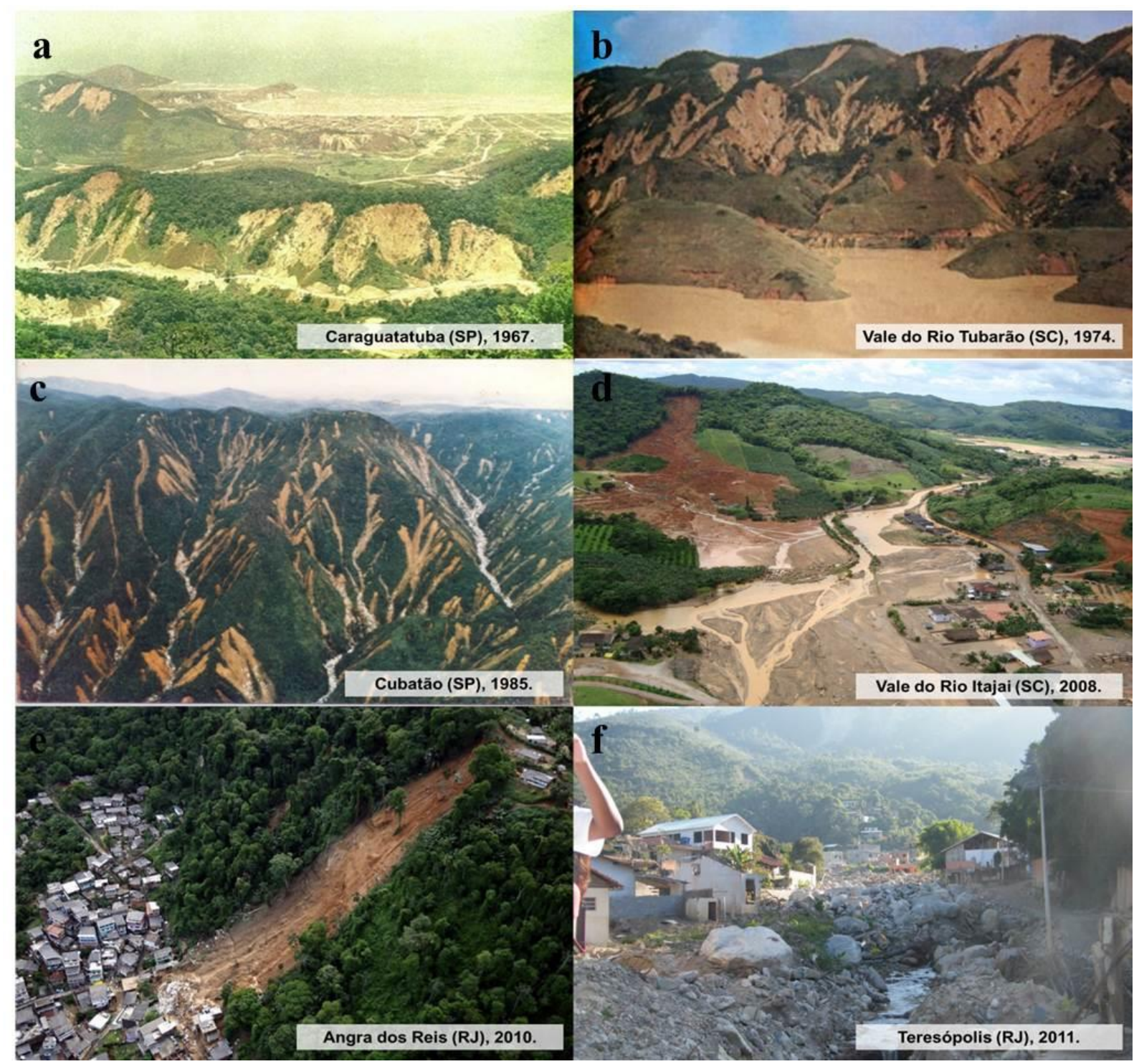

Figura 1: Escorregamentos e corridas de detritos em diferentes localidades das regiões serranas do Brasil. Os processos ocorreram de forma pontual e/ou generalizados, iniciando próximos aos divisores, alcançando a rede de drenagem, deslocando-se e ocupando as áreas mais planas das bacias. Fonte das imagens: (a) www.vitruvius.com.br; (b) Associação Brasileira de Mecânica dos Solos e Engenharia Geotécnica (c) Instituto de Pesquisas Tecnológicas; (d) Instituto Geológico; (e) 0 Globo; (f) Arquivo pessoal: Tulius Dias Nery.

No entanto, as corridas de detritos vêm tornando-se cada vez mais frequentes nos últimos anos, demandando maior conhecimento da sua localização e da sua dinâmica. É necessário ressaltar o empenho estabelecido por trabalhos do meio técnico-científico, sobretudo desde o evento de Santa Catarina (2008), região serrana do Rio de Janeiro (megadesastres de 2011), Serra do Mar Paranaense (2011), e mais recentemente em Itaóca (2014), em São Paulo. 
Decorrente à falta ou à dificuldade para obtenção das informações de eventos pretéritos, sua dinâmica de deflagração, alguns estudos vêm propondo métodos (semi-quantitativo, quantitativo e modelagem em base física), na tentativa de compreender a sua trajetória, as possíveis zonas de deposição (HATTANJI e MORIWAKI, 2009; CHEN e LEE, 2010; CHEN e YU, 2011), a sua frequência (IKEYA, 1981; TAKAHASHI, 1981; ELLEN et al., 1993) e os locais com potencial para sua ocorrência (SCALLY et al., 2001).

O emprego destes métodos foi impulsionado com a disseminação do uso dos Sistemas de Informações Geográficas (SIGs) (VAN WESTEN, 1993; ALEOTTI e CHOWDHURY, 1999), somado aos Modelos Digitais de Terreno (MDTs), que permitiram a aquisição e manipulação de informações, por exemplo, dos parâmetros e índices morfométricos, de forma prática e rápida dentro do ambiente SIG. Contribuíram assim, sistematicamente na modelagem, na identificação da suscetibilidade, do potencial de geração de sedimentos e no zoneamento do perigo (MELELLI e TARAMELLI, 2004; MARCHI e FONTANA, 2005; TOMINAGA, 2007).

Neste sentido, acredita-se que a combinação dos diferentes parâmetros e índices morfométricos pode auxiliar na compreensão da dinâmica e magnitude das corridas de detritos (JAKOB, 1996). Como exemplo dos parâmetros que podem ser empregados, pode-se citar a área, o comprimento do canal e a sua declividade média, o índice de circularidade, a amplitude e o ângulo da encosta (SILVEIRA et al., 2013; ROGELIS e WENER, 2014).

Devido ao crescimento populacional sobre as regiões suscetíveis a estes processos, estes tendem a aumentar o seu poder de impacto, podendo ocasionar eventos catastróficos (GLADE, 2005; MOREIRAS, 2006). Neste contexto, visando estabelecer ações preventivas e mitigadoras à minimização dos impactos dos movimentos de massa, em 10 de abril de 2012 foi instituído a Política Nacional de Proteção e Defesa Civil - PNPDEC, tendo como umas das premissas avaliar a suscetibilidade dos desastres naturais, em escala de bacia hidrográfica (BRASIL, 2012). Portanto, o emprego de modelos empíricos fundamentados em informações morfométricas pode contribuir na avaliação do potencial de geração de corridas de detritos, em escala de bacia hidrográfica nas regiões serranas brasileiras. 
Neste contexto, o capítulo 2 abordou as corridas de detritos e os seus mecanismos de deflagração; alguns estudos registrados no Brasil; os modelos empíricos para a análise de vazão de pico e do volume de sedimentos; o reconhecimento das feições por meio de fotointerpretação e o seu volume de sedimentos; além dos parâmetros e índices utilizados na avaliação das corridas de detritos. O contexto da área de estudo foi apresentado no capítulo 3. O capítulo 4 correspondeu aos procedimentos adotados no mapeamento dos escorregamentos e zonas de deposição e arraste das corridas de detritos; na identificação dos parâmetros e índices morfométricos; na hierarquização das áreas a serem avaliadas; e os cenários propostos. O capítulo 5 relatou os resultados obtidos ao longo da pesquisa. As conclusões da pesquisa e recomendações de trabalhos futuros correspondem ao capítulo 6 . 


\subsection{Hipótese e Objetivos}

Estudos voltados para o entendimento da dinâmica e dos fatores controladores das corridas de detritos são necessários. Entretanto, devido à dificuldade na aquisição de informações e na instrumentação outros métodos de análise podem ser propostos.

Neste contexto, a hipótese desta pesquisa considera que 0 uso de parâmetros e índices morfométricos (ex. área, amplitude, comprimento do canal, ângulo da encosta, índice de circularidade, densidade de drenagem e declividade média do talvegue principal) pode indicar áreas suscetíveis a corridas de detritos, assim como a sua magnitude em regiões declivosas como a Serra do Mar.

Desta forma, o objetivo principal desta pesquisa foi avaliar o potencial de geração de corridas de detritos em escala de bacia hidrográfica na Serra do Mar, no litoral norte do estado de São Paulo.

Os objetivos específicos foram:

- Identificar as áreas fontes de sedimentos (escorregamentos), por meio de fotointerpretação para estimar o volume de material das cicatrizes do evento de 1967;

- Identificar os depósitos ou zonas de arraste das corridas de detritos;

- Calcular os índices morfométricos das bacias e sub-bacias hidrográficas e sua contribuição para o desenvolvimento das corridas de detritos;

- Sistematizar (hierarquizar) as sub-bacias conforme os índices e a magnitude das corridas (cenários). 


\section{EMBASAMENTO TEÓRICO}

Neste capítulo é apresentada a revisão bibliográfica sobre a temática da tese e os respectivos modos de avaliação destes processos, os escorregamentos e as corridas de detritos. O item 2.1 refere-se ao conceito das corridas de detritos, seu modo de deflagração e os fatores condicionantes. Já as características de casos registrados no Brasil referem-se ao item 2.2. O item 2.3 refere-se ao levantamento de alguns modelos empíricos utilizados na avaliação destes processos. O item $\mathbf{2 . 4}$ apresenta os critérios adotados para a identificação das cicatrizes dos escorregamentos e das zonas de deposição e de arraste das corridas de detritos. $O$ item 2.5 apresenta uma revisão sucinta de alguns parâmetros e índices morfométricos empregados na análise e o seu papel na dinâmica das corridas de detritos.

\subsection{Corridas de detritos}

As corridas de detritos são movimentos rápidos nos quais os materiais se comportam como fluidos altamente viscosos apresentando-se como processos de caráter essencialmente hidrológicos (GUIDICINI e NIEBLE, 1976). De forma geral, desenvolvem-se nos canais de primeira a terceira ordem podendo alcançar o canal principal (BENDA e CUDY, 1990; GRAMANI, 2001; IPT, 2002; BENDA et al., 2003).

A ocorrência das corridas de detritos é condicionada por um conjunto de variáveis do meio físico que permite a sua formação e o seu desenvolvimento. Estas variáveis geológicas, geomorfológicas, hidrológicas e climatológicas contribuem simultaneamente na deflagração e no desenvolvimento do processo (RITTER et al., 1995; AUGUSTO FILHO e VIRGILI, 1998; IPT, 1987, 2002).

Sua deflagração pode ser decorrente da concentração e do escoamento rápido da água ao longo das redes de drenagens causando a remobilização do material depositado no canal e em sua margem (TAKAHASHI, 1981; 
ZIMMERMANN, 1990; RICKNMANN e ZIMMERMANN, 1993; RICKNMANN, 1999; GLADE, 2005; GODT e COE, 2007). Mas, outro mecanismo de deflagração decorre da transformação rápida do escorregamento, translacional/rotacional, em uma massa saturada (CAMPBEL, 1975; TAKAHSAHI, 1981; IPT, 1987) condicionadas pelas precipitações acumuladas (WIECZOREK, 1987; KANJl et al., 2003) que alcança rapidamente o canal de drenagem. Segundo Takahashi (1981) o entendimento deste último é complexo e, por vezes é difícil identificar a passagem de um processo para o outro (Figura 2).

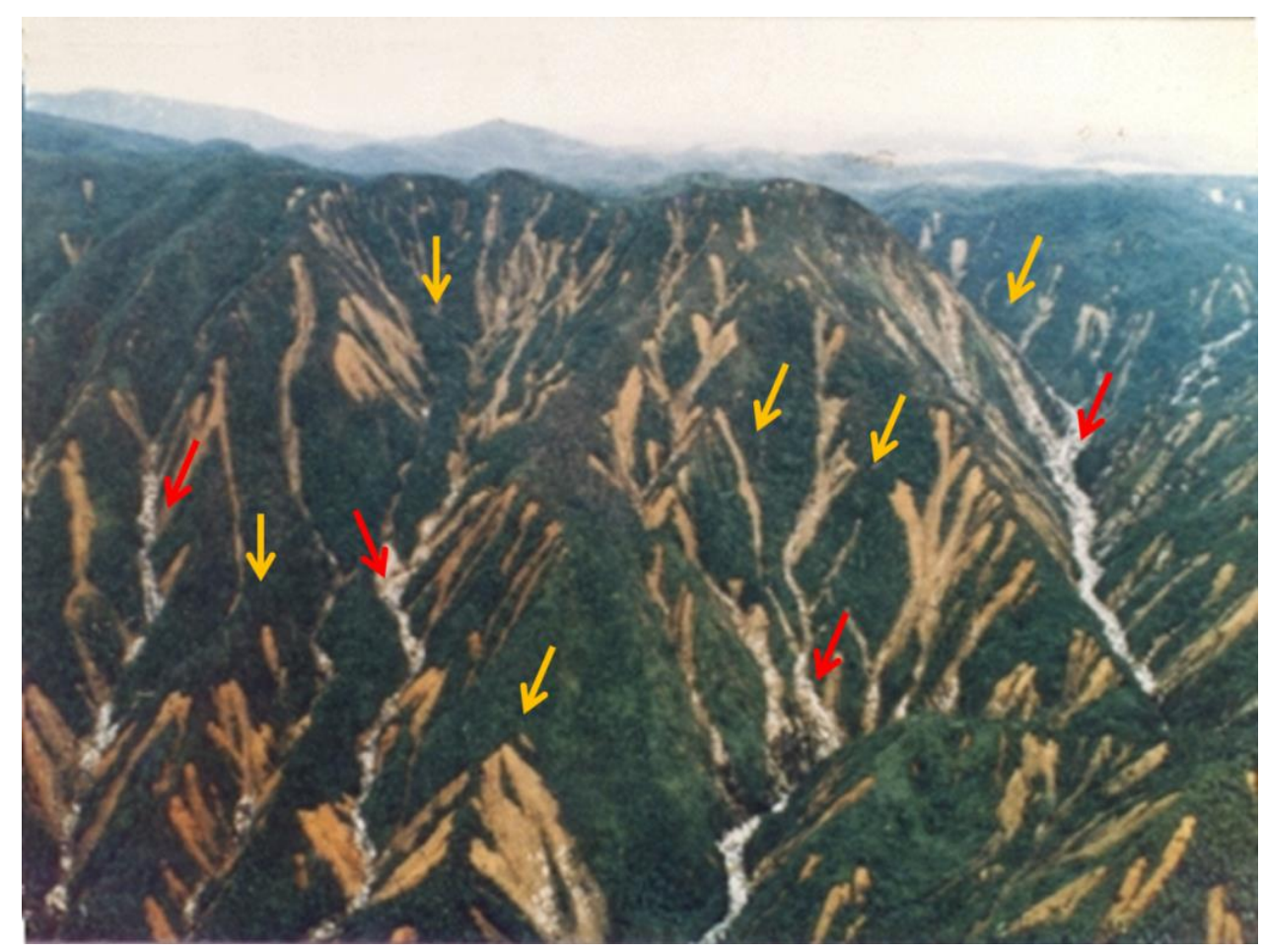

Figura 2: Escorregamentos na Serra do Mar, em Cubatão, em 1985. Diversos escorregamentos (setas em amarelo) forneceram materiais incorporados ao canal de drenagem, aumentando o volume sedimentar das corridas de detritos (setas em vermelho). Fonte: IPT.

Ressalta-se que o desenvolvimento e a evolução das corridas de detritos podem ocorrer por queda de blocos, assim, não tendo apenas sua iniciação associada aos escorregamentos (ZIMMERMANN, 1990; GLADE, 2005; AVELAR et al., 2006; BUDETTA, 2010). Segundo Avelar et al. (2006) e Budetta (2010), o impacto do bloco sobre uma massa saturada ou parcialmente saturada pode levar a liquefação instantânea e transformar-se em um material viscoso. 
As corridas podem ser compostas por materiais sólidos de tamanhos variados (rocha, detritos grossos, grãos finos de solo ou argila) e material orgânico, apresentando extenso raio de alcance, mesmo em áreas planas. Tendem a se tornar mais destrutivas quando o volume de material aumenta com a distância percorrida, devido, por exemplo, à declividade da encosta e às características da rede de drenagem (COSTA, 1984; IPT, 1986; ELLEN et al., 1987; FANNIN e ROLLERSON, 1993; IVERSON et al., 1997).

Sob a ótica da deflagração dentro do canal, a carga de material sólido é proveniente do material erodido ou da remobilização de material depositado ao longo da drenagem, por exemplo, devido ao barramento natural (knickpoints) ou pelo cessar do deslocamento de eventos pretéritos. A acumulação deste material sob condições de precipitações intensas $(\mathrm{mm} / \mathrm{h})$ pode causar o encharcamento e a inundação ao longo do canal e, consequentemente deflagrar uma nova corrida de detritos (TAKAHASHI, 1981; IPT, 1987; GRAMANI, 2001; KANJI et al., 2003; KANJI et al., 2008, KOBIYAMA et al., 2011).

As corridas de detrito deslocam-se, em geral, em forma de ondas/pulsos, com tempo de concentração variando de poucos minutos até a algumas horas, erodindo as margens dos canais e, consequentemente podem apresentar maior volume de material e maior mobilidade, por vezes extravasando para outro canal de drenagem (JONES, 1973; JACKOSN, 1978; IPT, 2002) (Figura 3). A deposição do material e o cessar do fluxo ocorrem em regiões mais planas e abertas (IPT, 1987; WOLLE e CARVALHO, 1994), com declividades entre $3^{\circ}$ e $10^{\circ}$ (IKEYA, 1981; LAWSON, 1982; BENDA e CUNDY, 1990; FANNIN e ROLLERSON, 1993), porém podem apresentar deposição parcial ou inicial em até $15^{\circ}$ (VANDINE, 1996) (Figuras 4 e 5). No entanto, o cessar pode também estar associado à perda do material confinante dentro do canal, ou seja, o espraiamento e, também, pelo impedimento do fluxo devido a barramentos naturais e artificiais (VANDINE, 1996). 


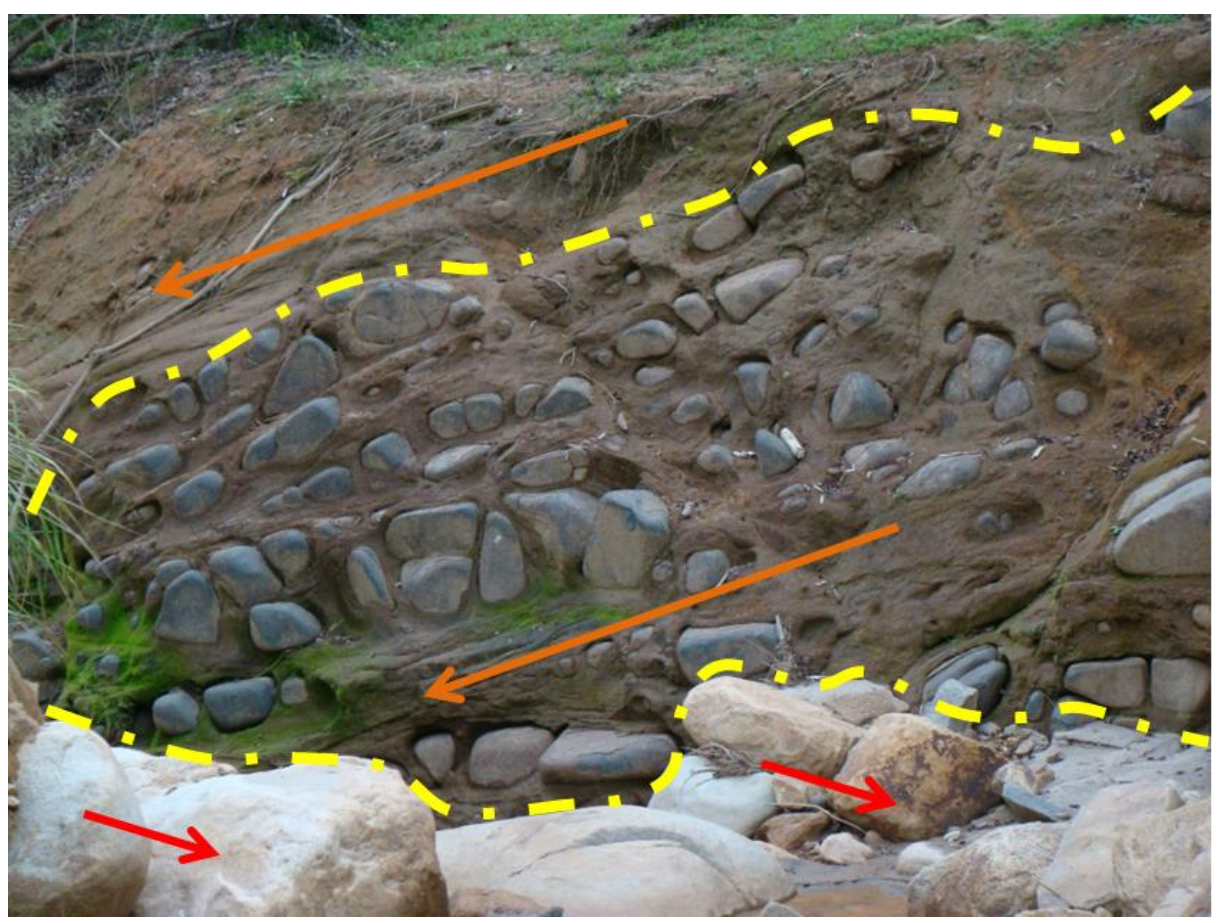

Figura 3: Depósitos de blocos na linha de drenagem (setas vermelhas) e possíveis depósitos pretéritos (linha tracejada amarela), exumados pela passagem da corrida de detritos de 2011. Observar o imbricamento dos clastos de tamanho variado e posicionados, em sua maior parte, para uma mesma direção (setas laranjas), envolto por uma matriz fina de sedimentos. Afluente do córrego do Cuiabá, Petrópolis-RJ. Fonte: Tulius Dias Nery, 2011.

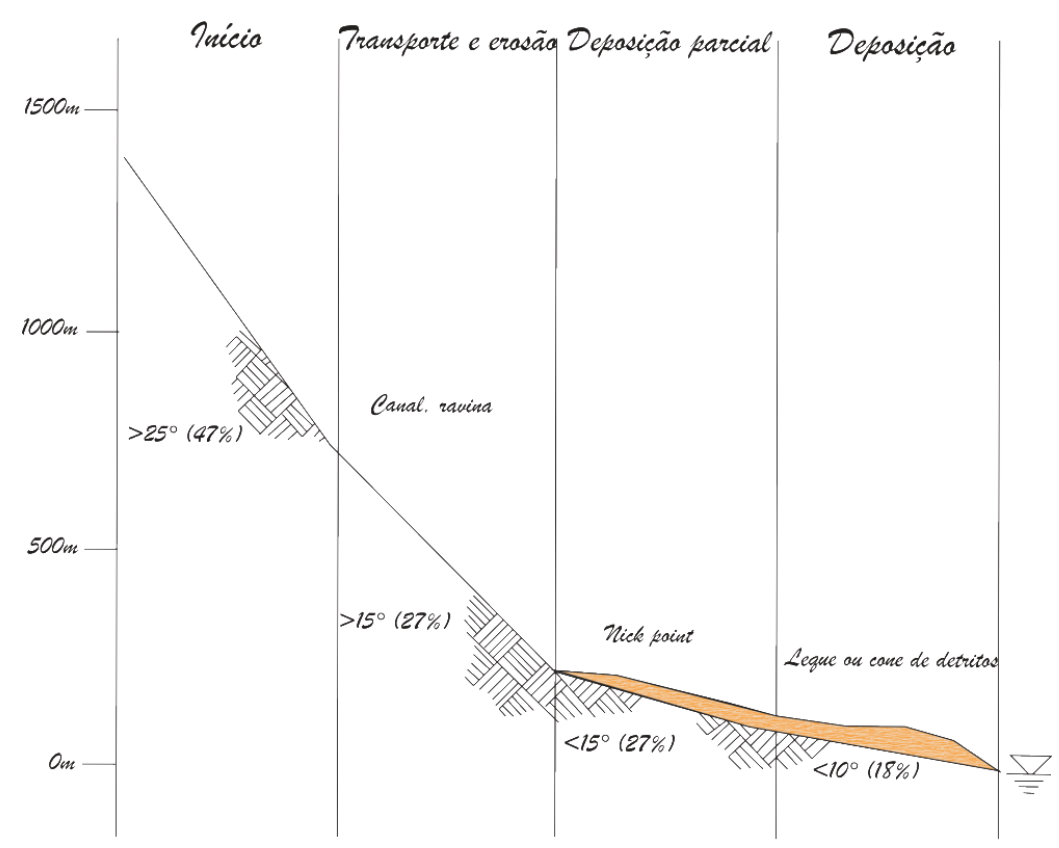

Perfil esquemática da declividade da canal

Figura 4: Perfil esquemático da declividade do canal. A zona inicial corresponde às áreas com declividades superiores a $25^{\circ}$; a zona de transporte e erosão associa-se com as áreas de declividades maiores que $15^{\circ}$; a zona de deposição parcial, em forma de dique, ocorre geralmente em declividades inferiores a $15^{\circ}$; e a deposição do material ocorre abaixo de $10^{\circ}$ (modificado de VANDINE, 1996). 


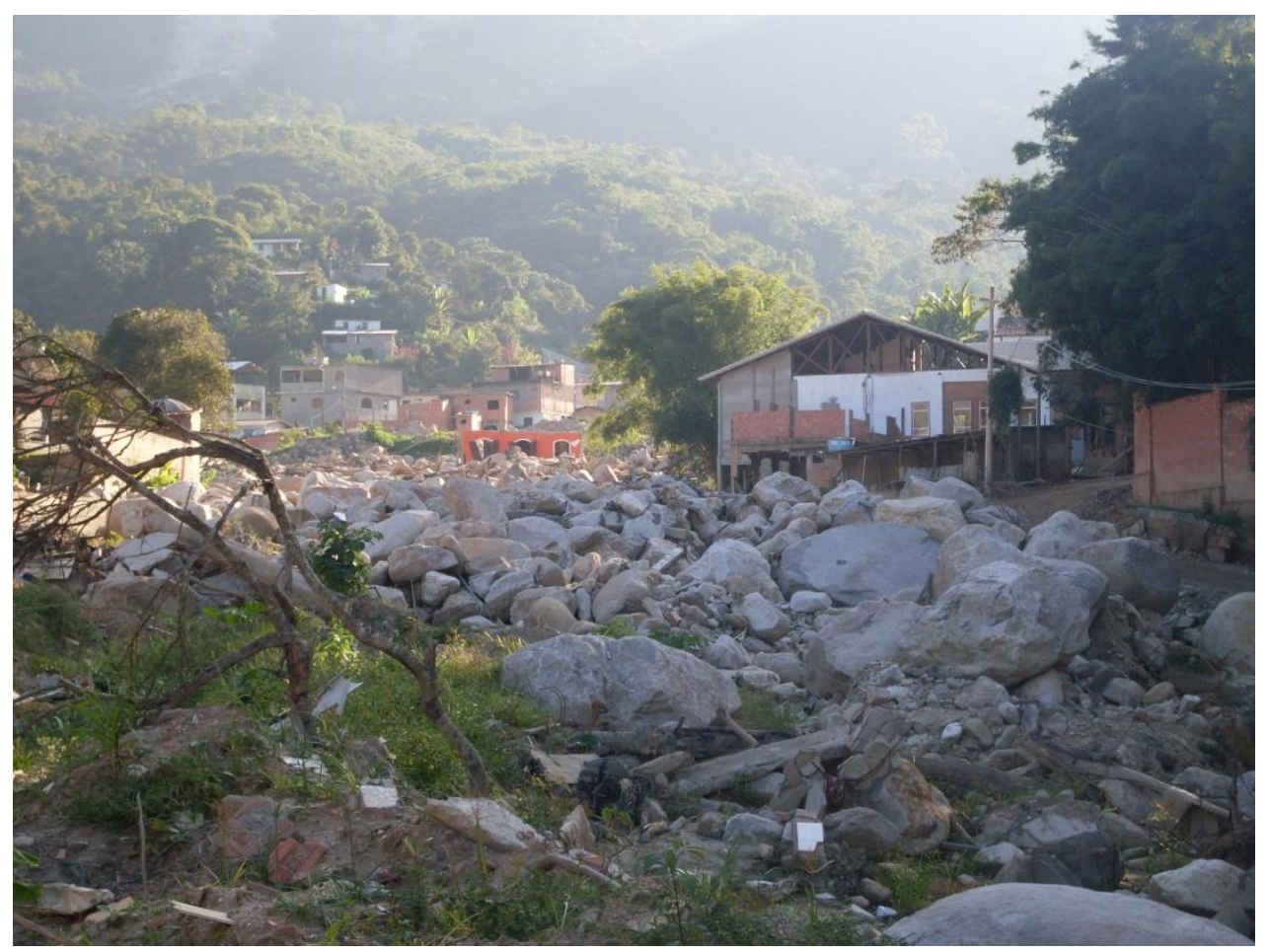

Figura 5: Depósitos da corrida de detritos em uma seção mais plana do córrego do Príncipe, bairro da Posse, Teresópolis (RJ). Observar o tamanho (diâmetro) dos sedimentos.

Van Steijn (1996) e IPT (2002) afirmam que o reconhecimento das corridas de detritos dá-se pela morfologia do seu depósito, observando um par de diques ou depósitos laterais ao longo do sulco principal e/ou lóbulos frontais no término do trajeto. Segundo Van Steijn (1996), estes elementos podem ser detectados no campo e a partir de fotografias aéreas.

A deposição do material das corridas de detritos depende do local de sua ocorrência, do canal (estreito e/ou aberto), da caraterística do detrito, bem como da existência de barreiras naturais ou artificiais. Sobre este aspecto, VanDine (1996) descreve que o comportamento da deposição pode ocorrer de três formas:

(I) Lâminas ou camadas de detritos (debris sheets) são geralmente depositadas sobre uma porção da área do leque de deposição, em que são caracterizados por um ramo ou canal de diferentes direções, apresentando uma forma geométrica semelhante a um "nariz" em sua fase final;

(II) Canais preenchidos parcialmente ou totalmente pelos detritos (debris plugs) caracterizam-se pelo comportamento de deposição ao longo do canal e em suas laterais e, consequentemente, quando da deposição total destes 
materiais no canal, podem resultar numa mudança brusca da direção de fluxo deste canal;

(III) Os diques de detritos (debris levees) são barreiras íngremes que podem ocupar ambas as margens dos canais, podendo apresentar vários metros de altura e estender-se por várias dezenas de metros ao longo do canal.

Em ambientes tropicais úmidos a ação intempérica ocorre de forma mais intensa sobre as rochas, e ainda que condicionadas à estrutura (falhas, diaclases etc.), às propriedades internas (texturais e mineralógicas), à coesão e o ângulo de atrito, esta ação favorece uma maior permeabilidade (RITTER et al., 1995) e, consequentemente à formação de espessos mantos de intemperismo e grandes depósitos coluvionares e aluvionares, proporcionando abundante áreas fontes passíveis de mobilização (COSTA, 1984).

Sobre os aspectos geomorfológicos, o ângulo da encosta, a orientação da encosta e a curvatura são condicionantes relevantes na deflagração destes processos. O ângulo da encosta contribui na disposição do material ao longo da encosta e na velocidade do movimento (HUHAIDA Jr., 1980). Além disso, as variações de espessuras e as características naturais destes materiais ao longo destas encostas podem contribuir no raio de alcance destes sedimentos (DAI e LEE, 2002).

As distintas condições de teor de umidade promovem a ação intempérica diferencial, resultando em solos rasos ou espessos; influenciam no tipo de vegetação; e condicionam a densidade de drenagem (CHURCHILL, 1982). O teor de umidade e as variações nos processos ativos na paisagem podem ser explicados, em grande parte, pela orientação da encosta, resultantes dos fatores estruturais e climáticos (HAVENITH et al., 2006; VANACÔR e ROLIM, 2012) e, consequentemente influência de forma indireta a ocorrência destes processos (DAI e LEE, 2002; CONFORTI et al., 2011). Associado a curvatura pode controlar o comportamento hidrológico, esta, responsável pelas zonas de fluxos superficiais e subsuperficiais, que podem favorecer a geração de zonas de saturação e, consequentemente podendo ocasionar o escoamento superficial (SMALL, 1970; 
CAMPELL, 1975; PIERSON, 1980; O'LOUGHLIN, 1981; WIECZOREK, 1987; MONTGOMERY et al., 1997). Do ponto das corridas de detritos, este escoamento superficial decorrente da saturação do manto e em associação ao regime de precipitação poderia levar a elevação do nível do canal mobilizando os materiais ali depositados (IPT, 1987; KANJI et al., 2003). 


\subsection{Estudos de caso sobre corridas de detritos no Brasil}

Este capítulo apresenta algumas características de corridas de detritos no Brasil. As informações contidas aqui são uma síntese dos eventos registrados em regiões serranas correspondendo à faixa leste brasileira, apresentadas por: STERNBERG (1949), DOMINGUES et al. (1971), JONES (1973), PELLERIN et al. (1997), GRAMANI (2001), IPT (2002), KANJI et al. (2003), KANJI et al. (2008), KOBYAMA et al. (2010) entre outros.

As corridas de detritos registradas ao longo das últimas décadas vêm demonstrando a importância do conhecimento da sua dinâmica, deflagração, velocidade do processo, raio de alcance, volume mobilizado e danos potenciais, como observado por Gramani (2001). Kanji et al. (2003) apresentaram algumas características sobre estes processos (Tabela 1), quanto ao registro, altura e distância $(H / L)$, precipitação, velocidade do processo, volume de material mobilizado e danos causados.

A relação $H / L$ corresponde à altura e à distância percorrida pela corrida de detritos e consequentemente pode elucidar o potencial erosivo e o volume de sedimentos gerado por este processo (RICKENMANN, 1999; GRAMANI, 2001). O registro para este parâmetro, no caso 10 eventos observados (entre 1967 e 2003), varia de 0,07 a 0,47. O maior índice desta relação associa-se às bacias do Quitite e Papagaio $(0,47)$ para o evento de 1996 e inversamente, o menor índice corresponde a Caraguatatuba (0,07), evento deflagrado em 1967 (KANJI et al., 2003).

A respeito da área da bacia, Mizuyama (1982) e Slaymaker (1988) afirmaram que seu conhecimento é relevante, pois bacias hidrográficas com áreas entre 0,1 $\mathrm{km}^{2}$ e $10 \mathrm{~km}^{2}$ são mais propensas a corridas de detritos. Nos casos analisados apenas 8 bacias apresentaram informações sobre este parâmetro, sendo que 7 estariam inseridas nesta margem. No entanto, este parâmetro quando associado ao ângulo da encosta apresenta uma melhor relação na ocorrência das corridas de detritos, visto que, quanto menor a área da bacia e maior for à inclinação da encosta maior será a probabilidade de sua ocorrência (VANDINE, 1985; GRAMANI, 2001). 
Tabela 1: Casos brasileiros de corridas de detritos

\begin{tabular}{|c|c|c|c|c|c|c|}
\hline Casos & Local & Área $\left(\mathrm{km}^{2}\right)$ & Precipitação & Vel. $(\mathrm{m} / \mathrm{s})$ & Vol. $\left(m^{3}\right)$ & Perdas \\
\hline Serra das Araras, 23/01/1967. & Rio de Janeiro & & $\begin{array}{c}114 \mathrm{~mm} / 1 \mathrm{~h} \\
275 \mathrm{~mm} / 24 \mathrm{~h}\end{array}$ & & $>10 \times 10^{6}$ & 1200 mortos, >100 casas destruídas, danos em rodovias. \\
\hline $\begin{array}{c}\text { Caraguatatuba, } \\
18 / 03 / 1967\end{array}$ & Caraguatatuba, SP & & $\begin{array}{l}420 \mathrm{~mm} / 24 \mathrm{~h} \\
586 \mathrm{~mm} / 48 \mathrm{~h}\end{array}$ & & $7,6 \times 10^{6}$ & 120 mortos, 400 casas destruídas, danos em rodovias. \\
\hline $\begin{array}{l}\text { Viaduto IV da ferrovia Santos - } \\
\text { Jundiaí, } 1971\end{array}$ & Santos, SP & & & & $1 \times 10^{5}$ (estimado) & $\begin{array}{c}\text { Viaduto de aço destruído, exigiu obras de estabilização de } \\
\text { encosta }\end{array}$ \\
\hline Campos do Jordão, 1973. & $\begin{array}{l}\text { Campos do Jordão, } \\
\text { SP }\end{array}$ & & & & & \\
\hline Tubarão, 1974 & Santa Catarina & & $\begin{array}{c}394 \mathrm{~mm} / 72 \mathrm{~h} \\
742 \mathrm{~mm} / 16 \text { dias }\end{array}$ & & & 195 mortos, cidade inundada com detritos. \\
\hline Rio Cachoeira, 1976 & Cubatão, SP & 4 & $\begin{array}{c}40 \mathrm{~mm} / 1 \mathrm{~h} \\
276 \mathrm{~mm} / 24 \mathrm{~h}\end{array}$ & & $1 \times 10^{5}$ & $\begin{array}{l}\text { Inundação da indústria da Copebrás com lama e detritos, } \\
\text { duas barragens de terra e alvenaria foram construídas. }\end{array}$ \\
\hline Lavrinhas, 1986 & Lavrinhas, SP & & & & & \\
\hline Petrópolis, 1988 & Petrópolis, RJ, & & $\begin{array}{c}145 \mathrm{~mm} / 24 \mathrm{~h} \\
414 \mathrm{~mm} / 144 \mathrm{~h}\end{array}$ & & & 171 mortos, 5 mil casas danificadas. \\
\hline Rio das Pedras (RPBC), 1994. & Cubatão, SP & 2,64 & $60 \mathrm{~mm} / 1 \mathrm{~h}$ & 10 & $3 \times 10^{5}$ & $\begin{array}{l}\text { Inundação da Refinaria da Petrobrás com detritos, } \\
\text { interrupção das operações e limpeza (US\$ 44mi). }\end{array}$ \\
\hline $\begin{array}{l}\text { Timbé do Sul de Timbé do Sul, } \\
1995 .\end{array}$ & SC/RS & 23,1 & $>500 \mathrm{~mm} / 1 \mathrm{~h}$ & $>5$ & $3 \times 10^{6}$ & 29 mortos, 20 casas destruídas, perdas (agricultura e gado). \\
\hline $\begin{array}{l}\text { Rio das Pedras (RPBC), } 1996 . \\
\text { Rodovia de Ubatuba, } 1996 .\end{array}$ & $\begin{array}{l}\text { Cubatão, SP } \\
\text { Ubatuba, SP }\end{array}$ & 2,64 & $\begin{array}{l}>10 \mathrm{~mm} / 10 \mathrm{~min} \\
442 \mathrm{~mm} / 13 \mathrm{~h}\end{array}$ & 10 & $1,6 \times 10^{4}$ & $\begin{array}{c}\text { Apenas trabalho de limpeza } \\
\text { Rodovia danificada exigiu obras de estabilização da } \\
\text { encosta. }\end{array}$ \\
\hline $\begin{array}{l}\text { Maciço do Quitite e Papagaio, } \\
1996 .\end{array}$ & Rio de Janeiro, RJ & $\begin{array}{l}2,13(\mathrm{Q}) \\
2,53(\mathrm{P})\end{array}$ & $250 \mathrm{~mm} / 48 \mathrm{~h}$ & 5,3 & $\begin{array}{l}5,3 \times 10^{4}(\mathrm{Q}) \\
2,8 \times 10^{4}(\mathrm{P})\end{array}$ & 1 morto, centenas de casas destruídas. \\
\hline Rodovia Anchieta, 1999 & São Paulo & & $\begin{array}{l}128 \mathrm{~mm} / 24 \mathrm{~h} \\
274 \mathrm{~mm} / 72 \mathrm{~h}\end{array}$ & & $3 \times 10^{5}$ & $\begin{array}{c}200 \text { m de área afetada e tráfego interrompido por várias } \\
\text { semanas. }\end{array}$ \\
\hline Lavrinhas, 2000 & Lavrinhas, SP & 17,5 & $>70 \mathrm{~mm} / 1 \mathrm{~h}$ & 22 & $1,6 \times 10^{6}$ & 11 mortos, muitas casas e pontes destruídas. \\
\hline Vale do Itajaí, 2008 & Santa Catarina & & & & & $\begin{array}{c}32,853 \text { pessoas desalojadas, } 135 \text { mortos e } 2 \text { desaparecidos } \\
\text { no estado. }\end{array}$ \\
\hline $\begin{array}{l}\text { Córrego D'antas, } 2011 . \\
\text { Córrego das Vieira, } 2011 .\end{array}$ & $\begin{array}{l}\text { Nova Friburgo, RJ } \\
\text { Nova Friburgo, RJ }\end{array}$ & $\begin{array}{l}52 \\
33\end{array}$ & $266 \mathrm{~mm} / 48 \mathrm{~h}$ & & & $\begin{array}{c}429 \text { mortos, pessoas desaparecidas, } 3.220 \text { desalojados, } \\
2.031 \text { desabrigados e inúmeros prejuízos. }\end{array}$ \\
\hline Bairro da Posse, 2011. & Teresópolis, RJ & 12 & $124,6 \mathrm{~mm} / 24 \mathrm{~h}$ & & & $\begin{array}{c}343 \text { mortos, pessoas desaparecidas, } 9.110 \text { desalojados, } \\
6.727 \text { desabrigados e inúmeros prejuízos. }\end{array}$ \\
\hline Córrego do Cuiabá, 2011. & Petrópolis, RJ & 36 & & & & $\begin{array}{c}71 \text { mortos, pessoas desaparecidas, } 6.223 \text { desalojados, } 191 \\
\text { desabrigados e inúmeros prejuízos. }\end{array}$ \\
\hline Serra da Prata, 11/03/2011 & $\begin{array}{l}\text { Paranaguá e } \\
\text { Morretes/PR }\end{array}$ & 45,23 e 4,587 & $\begin{array}{c}231 \mathrm{~mm} / 24 \mathrm{~h} \text { e } 348 \\
\mathrm{~mm} / 72 \mathrm{~h}\end{array}$ & & & $\begin{array}{l}\text { Prejuízos por destruição total ou parcial de casas, ruas, } \\
\text { estradas, pontes e lavouras. Pessoas feridas e } 1 \text { óbito }\end{array}$ \\
\hline Ribeirão Cágado, 2013 & Cubatão, SP & 0,26 & $273,6 \mathrm{~mm} /<24 \mathrm{~h}$ & & & \\
\hline
\end{tabular}


Nos casos analisados na Tabela 1 os valores de precipitação acumulada em 72 horas variam entre 274 a 394 mm; em 48 horas entre 250 a 586 mm; e em 24 horas entre 124,6 a $420 \mathrm{~mm}$. Alguns casos apresentaram intensidade de precipitação $(\mathrm{mm} / \mathrm{min}$ ou $\mathrm{mm} / \mathrm{h})$ entre $>10 \mathrm{~mm} / \mathrm{min}$ a $114 \mathrm{~mm} / \mathrm{h}$. Estes valores de intensidade de precipitação estão de acordo com as ocorrências das corridas de detritos pois, segundo Gramani (2013), a deflagração pode ocorrer com valores de 10 a $20 \mathrm{~mm}$ em $10 \mathrm{~min}$ e/ou 80 a $100 \mathrm{~mm}$ em $1 \mathrm{~h}$.

O volume de material mobilizado (Tabela 1) apresenta correlações intrínsecas entre o volume de sedimentos e a precipitação. Valores de volume na ordem de $1 \mathrm{x}$ $10^{6} \mathrm{a}>10 \times 10^{6} \mathrm{~m}^{3}$ estão associados à intensidade de precipitação $(\mathrm{mm} / \mathrm{h})$ e valores de volume de $1,6 \times 10^{4}$ a $9 \times 10^{4} \mathrm{~m}^{3}$ à precipitação acumulada em $24 \mathrm{~h}$ e $48 \mathrm{~h}$. Ressalta-se aqui o caso de Caraguatatuba (SP) que apresentou um volume na ordem de $10^{6} \mathrm{~m}^{3}$, porém os eventos ocorreram com precipitação acumulada de $24 \mathrm{~h}$ e $48 \mathrm{~h}$, destoando dos demais eventos desta mesma ordem. 


\subsection{Relações empíricas das corridas de detritos}

A avaliação sobre a ocorrência de corridas de detritos em relação à sua gênese, a sua frequência e a sua magnitude (volume) pode ser feita por meio de métodos semi-quantitativos, quantitativos e modelagem em base física (RICKENMANN, 1999; GLADE, 2005).

Para o entendimento destes processos se faz necessário o levantamento de informações detalhadas, em campo ou em laboratório. No entanto, estas podem não ser acessíveis e/ou aplicadas, apresentando-se como uma limitação. Por outro lado, estes fenômenos podem ser compreendidos pelos parâmetros morfométricos da bacia, pela geologia, pela geomorfologia e pelo uso do solo. Este último é mais comumente utilizado para o zoneamento de perigo (FANNIN e BOWMAN, 2008).

Neste sentido, os parâmetros, tais como, o volume $(M)$, vazão de pico $\left(Q_{p}\right)$, velocidade do front $(V)$, seção transversal do fluxo $(A)$, distância total percorrida $(L)$ e distância percorrida sobre o leque (depósito) $\left(L_{f}\right)$, vêm sendo propostos por meio de fórmulas empíricas para estimar a sua importância no entendimento das corridas de detritos (BENDA e CUNDY, 1990; FANNIN e ROLLERSON, 1993; COROMINAS, 1996; RICKENMANN, 1999, KANJI et al., 2007; entre outros). Estas formulações são baseadas na análise de séries históricas de corridas de detritos, deflagradas em ambientes similares, para avaliar as relações entre as características da bacia e o volume máximo mobilizado (WRACHIEN e MAMBRETTI, 2011). Neste contexto, algumas formulações sobre vazão de pico, magnitude e distância percorrida são apresentadas neste item.

Rickenmann (1999) observou que uma aproximação ou estimativa de volume de sedimentos pode ser usada para avaliar outros parâmetros, por exemplo, a vazão de pico e a relação das distâncias percorridas em detrimento ao volume mobilizado.

Decorrente de sua experiência com as corridas de detritos Araya Moya (1994) propôs uma relação empírica para estimar a vazão de pico para os eventos ocorridos no Chile (Equação 1): 


$$
q_{T}=1,4 \cdot \frac{1}{(1-c)} \cdot 0,85 \cdot A \cdot I \cdot \frac{H^{0,19}}{L^{0,58}} \ldots \ldots \ldots . . . \text { Eq. } 1
$$

Onde $c$ é a concentração dos sólidos $\left(\mathrm{m}^{3}\right) ; A$ é a área da bacia $\left(\mathrm{km}^{2}\right) ; I$ é a intensidade média máxima de precipitação em 24 horas; $H$ é a diferença máxima, em altura $(\mathrm{m})$, dentro da bacia; e $L$ é o comprimento total do rio $(\mathrm{km})$.

Massad et al. (1997), por meio de retroanálises de eventos ocorridos no Brasil e no Japão, propuseram uma formulação considerando a intensidade de precipitação. Para estes autores a intensidade de precipitação $(\mathrm{mm} / \mathrm{h})$ que precede o evento é mais significativa, fornecendo uma melhor exatidão na correlação da precipitação e as corridas de detritos, em âmbito nacional. Portanto a formulação é dada por (Equação 2):

$$
q_{T}=\frac{2}{(1-c)} \cdot A \cdot I_{1} \ldots \ldots \ldots \text { Eq. } 2
$$

Onde $I_{1}$ é a intensidade de precipitação acumulada horária $(\mathrm{mm} / \mathrm{h})$ que precede o evento.

A partir de observações dos eventos ocorridos na Serra do Mar, em que a intensidade de precipitação antecedente ao evento mostrou-se importante na deflagração das corridas de detritos, Massad et al. (1997) modificaram a variável de precipitação $I$ da Equação 1 (ARAYA MOYA, 1994) por $I_{1}$ desconsiderando assim, a intensidade média máxima de precipitação em 24 horas (Equação 3):

$$
q_{T}=1,4 \cdot \frac{1}{(1-c)} \cdot 0,85 \cdot A \cdot I_{1} \cdot \frac{H^{0,19}}{L^{0,58}} \ldots \ldots \ldots \text { Eq. } 3
$$

A saber, a concentração de sólidos (c) é a fração das partículas dos sedimentos, por unidade de volume, e podem variar, segundo observações de campo e em laboratório entre 30\% e 90\% (DAVIES et al., 1992; COUSSOT e 
MEUNIER, 1996; IPT, 2002; GODT e COE, 2007; UEHARA et al., 2008). Entretanto, o material envolvido nestes processos pode apresentar uma mistura granulométrica, de sedimentos finos até blocos com dezenas de metros de diâmetro (SILVEIRA et al., 2013; ZNAMENSKY, 2014).

A relação empírica de vazão de pico proposta por Rickennman (1999) fundamenta-se na Escala de Froude, em que, os fluxos apresentam diferentes tamanhos, mas com as mesmas propriedades físicas (Equação 4):

$$
Q_{*}=0,1 M_{*}^{0,833} \ldots \ldots \ldots . . \text { Eq. } 4
$$

Onde $Q_{*}$ e $M_{* 1}$ são demostradas pelas equações 5 e 6

$$
\begin{gathered}
Q_{*}=Q_{p 2} / Q_{p 1} \ldots \ldots \ldots . . \text { Eq. } 5 \\
M_{*}=M_{p 2} / M_{p 1} \ldots \ldots \ldots \text { Eq. } 6
\end{gathered}
$$

Os índices 1 e 2 nas formulações, $Q_{*}$ e $M_{*}$ são relatados para dois tipos de fluxos de propriedades materiais similares, porém de tamanhos diferentes. Maiores detalhes sobre estas equações (4 a 6) podem ser encontrados em Rickennman (1999).

Jakob (1996) define magnitude como o volume total de sedimentos transportados pelo canal até a sua deposição. VanDine (1996) define como um volume de material que é suscetível à mobilização em um dado evento, podendo, em última análise formar um leque de deposição. Marchi e D’Agostino (2004) definem como o volume total da vazão de sedimentos durante um único evento, independentemente do número de picos.

Aqui, entende-se que a magnitude é o volume total de sedimentos transportados, independente dos diferentes pulsos, ou seja, considera-se a 
deflagração da corrida de detritos como um único evento, como observado por Marchi e D'Agostino (2004). Assume-se esta definição, pois tais formulações não levam em consideração os diferentes estágios de desenvolvimento destes processos. Helsen et al. (2002) afirmam que o volume pode ser estimado a partir da geometria do depósito. Baseando-se no evento ocorrido em 1996 no vale Valgaudemar, Alpes Franceses, e a partir das informações sobre outros eventos, Helsen et al. (2002), propuseram uma formulação para estimar o volume de corridas de detritos, principalmente para obter valores estimados dos eventos ocorridos no passado (Equação 7):

$$
V_{\text {old }}=\frac{V_{\text {fresh }}}{A_{\text {fresh }}} \cdot A_{\text {old }} \cdots \cdots \ldots . . . \text { Eq. } 7
$$

Onde $V_{\text {old }}$ é o volume do depósito pretérito da corrida de detritos, $V_{\text {fresh }}$ é o volume do depósito recente da corrida de detritos, $A_{\text {old }}$ é a área do depósito pretérito e $A_{\text {fresh }}$ é a área do depósito recente.

Devido à dificuldade em obter a concentração de sólidos $\left(c^{*}\right)$ envolvidos nas corridas de detritos, formulações empíricas utilizando-se da vazão de pico são empregadas na análise destes processos (KANJl et al., 2003; 2008). Então, o cálculo de volume total $\left(V_{T}\right)$ de sedimentos em relação à vazão de pico $\left(q_{T}\right)$ fundamenta-se na Equação 8 proposta por Takahashi (1991):

$$
V_{T}=500 \cdot q_{T} \quad \text { Eq. } 8
$$

A relação volume e distância percorrida pela corrida de detritos pode ser importante para determinar ou delimitar a magnitude e o potencial de impacto sobre o meio (físico ou social) (FANNIN e BOWMAN, 2008). Fannin e Rollerson (1993), em observações a respeito de 449 corridas de detritos ocorridas na Columbia Britânica, formularam a Equação 9, objetivando calcular o volume de material incorporado nestes processos. 


$$
V=\frac{V_{d}}{(L-l)} \ldots \ldots \ldots \text { Eq. } 9
$$

Onde $V_{d}$ é o volume de material de sedimentos observado na área terminal do depósito, $L$ é a distância da escarpa principal em relação ao depósito final, e $l$ é comprimento da área de deposição. Segundo os autores a área $(A)$ de um dado evento é definida pelo cálculo do comprimento e largura que o sedimento alcança.

Corominas (1996) analisando as ocorrências dos movimentos de massa, entre eles as corridas de detritos, propôs uma formulação que combina a altura e o comprimento do processo (Equação 10). A fórmula é expressa por:

$$
V=\left(\frac{L}{1,03 H}\right)^{\frac{1}{0,105}} \ldots \ldots \ldots \ldots \text {..... } 10
$$

Onde $V$ é o volume estimado $\left(\mathrm{m}^{3}\right), H$ é altura da elevação em relação ao ponto inicial e final da corrida de detrito $(m)$, e $L$ é a distância na horizontal do trajeto do processo $(m)$.

Rickennman (1999) observando a relação volume, altura e comprimento e na tentativa de validar esta relação propôs a equação 11. A relação de volume e diferença de elevação pode ser considerada, segundo Rickennman (1999), como a energia potencial do movimento de massa.

$$
V=\left(\frac{L}{1,90 H_{e}^{0,83}}\right)^{\frac{1}{0,160}} \ldots \ldots \ldots . \text { Eq. } 11
$$

Onde $H_{e}$ é a diferença de elevação entre o ponto inicial e o ponto final da massa e $L$ é a distância total percorrida. 
Kobiyama et al. (2010), em estudos realizados na cidade de Rio do Cedros (SC) e com objetivo de estimar o volume gerado por uma corrida de detritos, em 2008, formularam a equação 12 :

$$
V_{\text {Debris }}=V_{\text {debris } 1}+V_{\text {debris } 2}=\frac{\frac{4}{3} \pi a_{1} b_{1} c_{1}}{2}+\frac{\frac{4}{3} \pi a_{2} b_{2} c_{2}}{2} \ldots \ldots \ldots \text { Eq. } 12
$$

Onde $V_{\text {Debris }}$ é o volume total do movimento de massa das corridas de detritos A ou B, $V_{\text {debris1 }}$ e $V_{\text {debris } 2}$ são o volume dos dois movimentos iniciais, $a_{1}$ e $a_{2}$ são números positivos que representam a dimensão $X$ dos dois elipsoides, $b_{1}$ e $b_{2}$ são números positivos que representam a dimensão $Y$ dos dois elipsoides, $c_{1}$ e $c_{2}$ são números positivos que representam a dimensão $Z$ dos dois elipsoides ${ }^{1}$ (Figura 6).
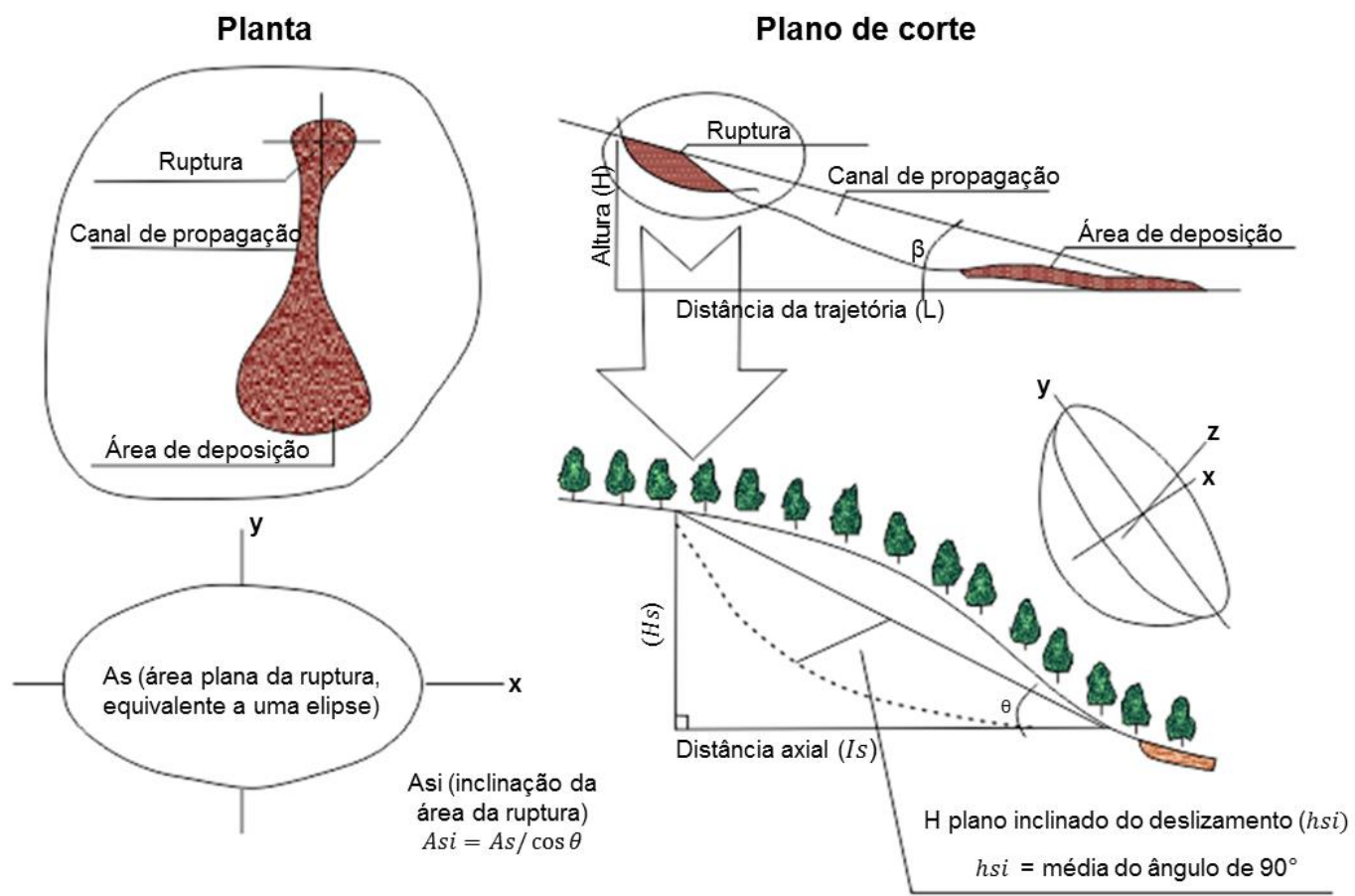

Figura 6: Geometria da corrida de detrito (modificado de Kobiyama et al., 2010).

\footnotetext{
1 Baseados sobre observações de campo, os autores verificaram que as superfícies de ruptura dos escorregamentos assemelham-se a um elipsóide. Segundo os autores esta suposição geométrica permitiu calcular o volume do movimento de massa para cada ponto inicial do processo.
} 
Algumas das formulações utilizadas, de forma indireta, para estimar a vazão de pico, o volume e distância ou trajeto percorrido pelo processo foram apresentadas neste capítulo. Salienta-se que há uma grande variedade de formulações que envolvem medições diretas e indiretas para compreender a dinâmica da corrida de detrito. Decorrente da não medição dos parâmetros em campo e da falta de informações detalhadas sobre estes processos, a estimativa serve como base e, consequentemente pode preencher a lacuna sobre 0 comportamento destes fenômenos em regiões serranas brasileiras. 


\subsection{Mapeamentos das feições (Cicatrizes e Depósitos)}

O uso de fotografias aéreas ou imagens de satélite no mapeamento das feições dos movimentos de massa auxilia na identificação e delimitação da sua ocorrência fornecendo uma visão tridimensional da área afetada, resultando em um mapa (ZÁRUBA e MENCL, 1976; MANTOVANI et al., 1996; GUZZETTI et al., 2012).

Leroi et al. (1992) afirmaram que este método torna-se ineficaz para identificação e mapeamento da suscetibilidade em escala regional devido ao seu caráter analógico (fotografias aéreas) e ao fato de tais ferramentas fornecerem acesso limitado para a grande variedade dos fatores desencadeadores. Contudo, Barlow et al. (2003) retrataram que em áreas montanhosas, o emprego desta técnica é válido, sobretudo em áreas em que o acesso é restrito, dificultando a aquisição de informações.

Para o mapeamento das feições dos movimentos de massa (escorregamentos e corridas de detritos) alguns critérios devem ser levados em consideração na identificação destes processos: o tamanho, pois descreve a extensão da área do processo; a vegetação, pois reflete na condição de presença ou ausência desta, facilitando o seu reconhecimento sobre a imagem; a textura, que reflete o tipo de superfície e o tamanho do sedimento; a posição topográfica e; a forma, caracterizada pela concavidade na parte superior e pela convexidade na parte inferior da encosta, indicando assim a presença de um movimento de massa (BARLOW et al., 2003; GUZZETTI et al., 2012; SESTINI e FLORENZANO, 2014) (Figuras 7 e 8). Sobre este último item Guzzetti et al. (2012) apontaram que a combinação de uma forma geométrica em cone, em planta, e na parte superior convexo, em perfil, é interpretado como um leque aluvial, um cone de sedimentos ou uma zona de deposição de corrida de detrito. 

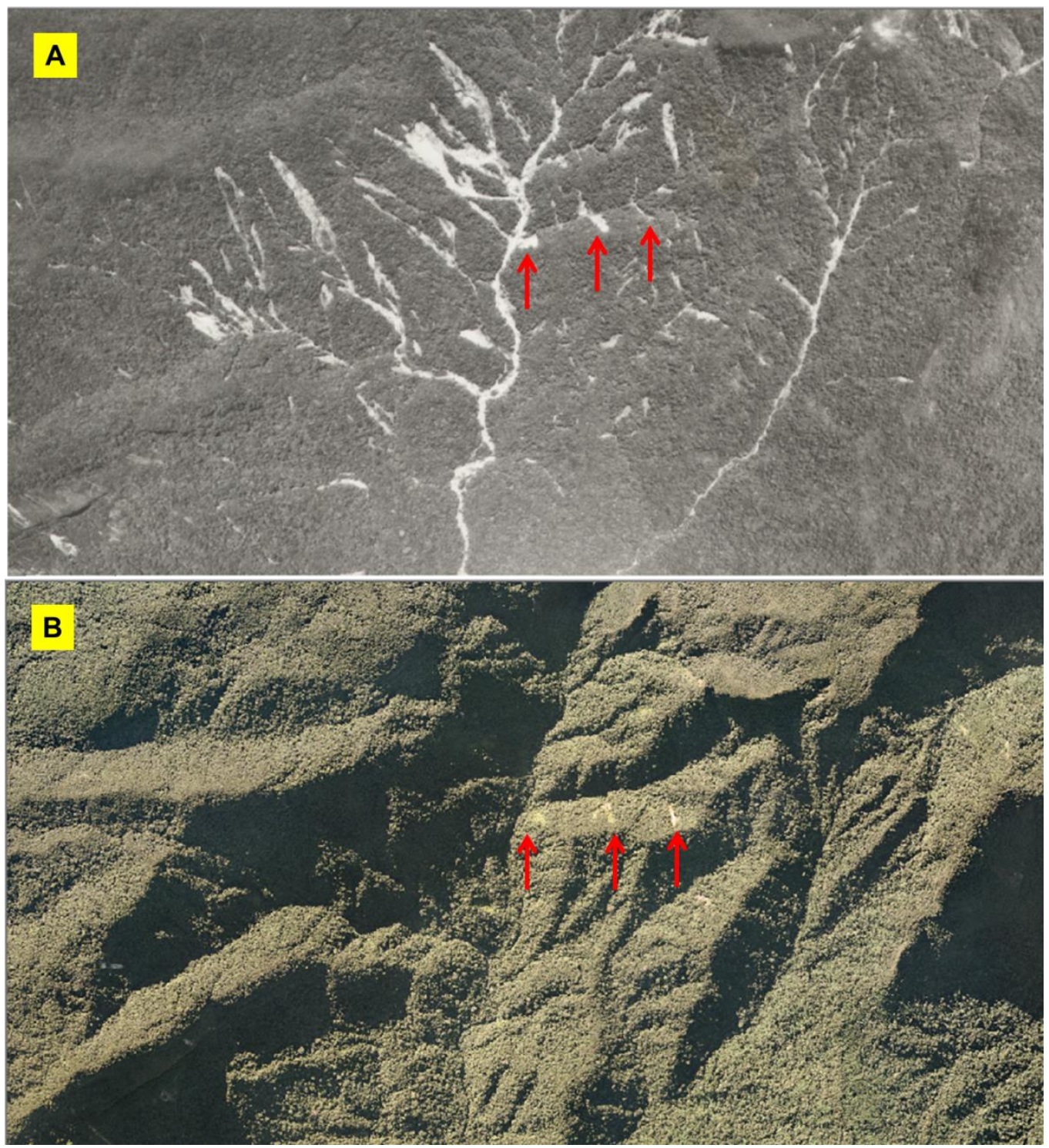

Figura 7: Cicatrizes de escorregamentos e de corridas de detritos deflagrados na bacia do rio Mococa. Na fotografia aérea (a), diferentes setores das encostas foram afetados por estes processos, apresentando geometrias variáveis. Na ortofoto (b) é possível identificar (setas vermelhas) as encostas onde ocorreram os escorregamentos 1967. 


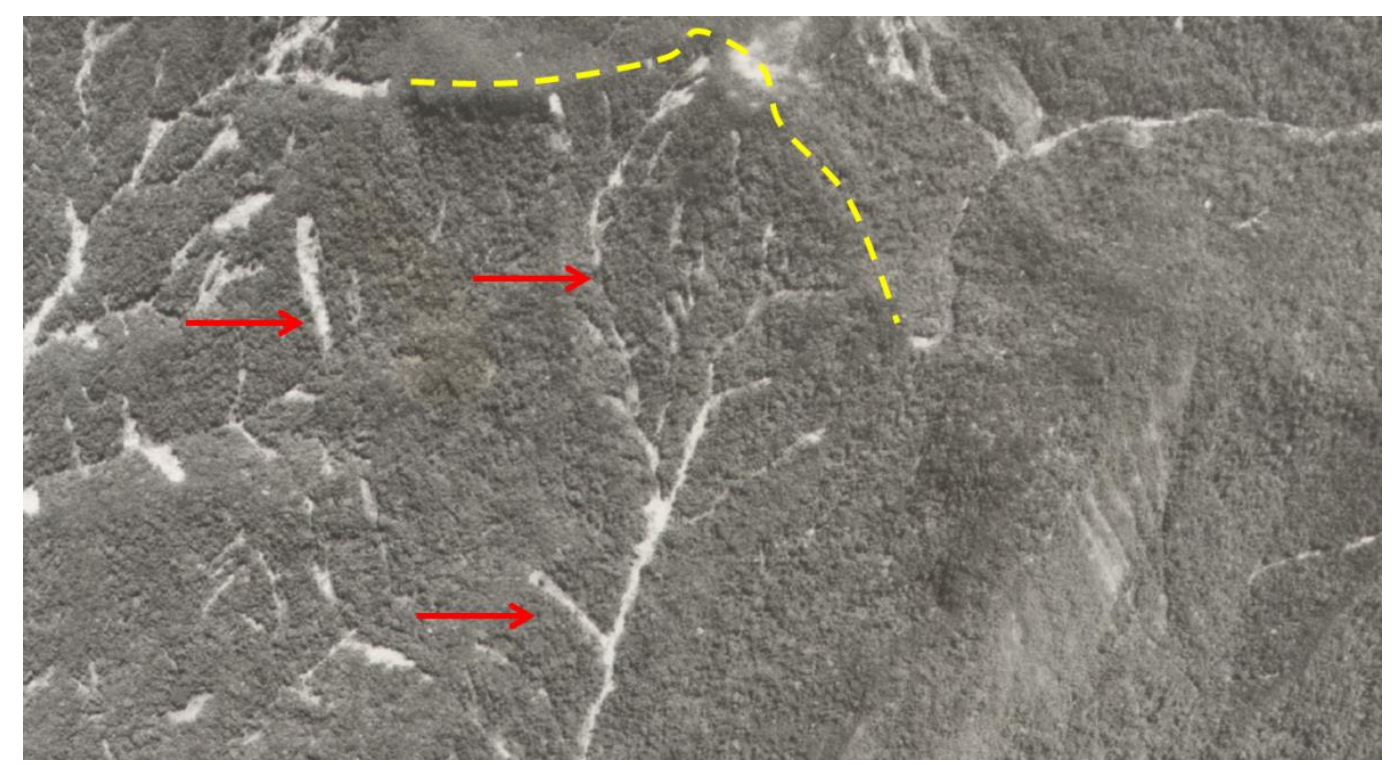

Figura 8: Observa-se que alguns processos ocorreram nos divisores da bacia e sub-bacias (linha tracejada amarela). Chama-se atenção para a diferença de tonalidade e de geometria permitindo a sua identificação na fotografia aérea (seta vermelha).

A determinação do volume destes processos apresenta-se como uma difícil tarefa, exigindo informações a respeito da geometria da superfície e subsuperfície (GUZZETTI et al., 2009). No entanto, Nikolaeva et al. (2014) afirmaram que a caracterização destas feições (ex: localização, forma e tamanho do plano de deslocamento) permite estimar o volume destes processos. A partir do reconhecimento destas feições, vêm sendo propostas diferentes técnicas para obtenção do volume de sedimentos (FÚLFARO et al., 1976; CANNON, 1989; AUGUSTO FILHO, 1993; entre outros).

Sobre o volume de sedimentos derivado dos escorregamentos, Fúlfaro et al. (1976), adotaram o seguinte procedimento: o material afetado pelo escorregamento refere-se ao vazio deixado na superfície topográfica, e assumindo-se a forma do vazio a uma cunha, com dimensões estabelecidas a partir da área do escorregamento (em planta) e das medidas diretas do levantamento de campo. Posteriormente, os valores obtidos foram multiplicados pelo valor de densidade dos solos $\left(1,8\right.$ ton $\left./ \mathrm{m}^{3}\right)$, obtendo assim os valores estimados de sedimentos.

Para as corridas de detritos, Cannon (1989), a partir do programa GEOPROGRAM e de fotografias aéreas, em escala de 1:6.000, delimitou a área 
correspondente às corridas de detritos. Segundo o autor, um plano paralelo à base da cicatriz, foi traçado e registrado (ponto a ponto) originando a forma tridimensional da área, permitindo o cálculo do volume estimado na área definida pelo programa (Figura 9).

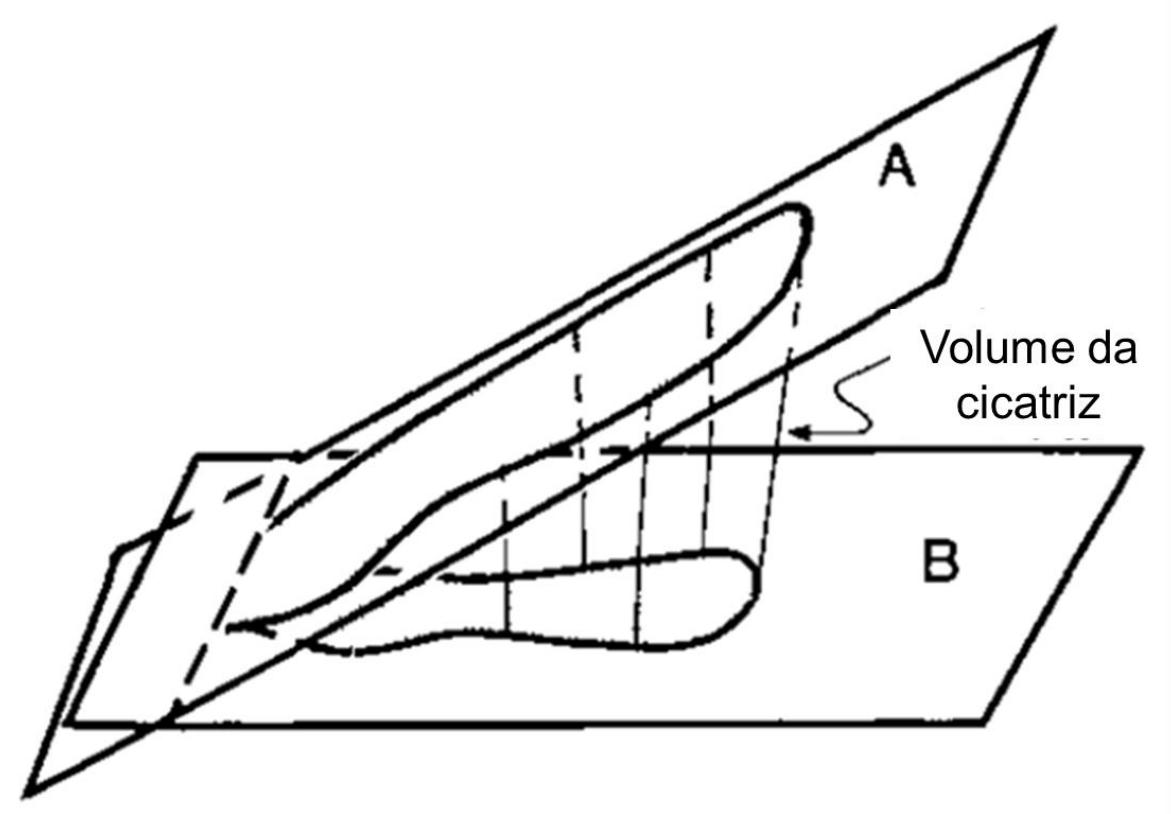

Figura 9: llustração do método usado para o cálculo de sedimentos por meio de fotografias aéreas. Fonte: Adaptado de Cannon, 1989.

Augusto Filho (1993) calculou o volume de material mobilizado admitindo que a partir de um dado evento pluviométrico crítico, os escorregamentos ocorridos em encostas de suscetibilidade muito alta podem contribuir para as corridas de massa com $50 \%$ de sedimento. Este volume de sedimentos representaria $0,5 \mathrm{~m}$ da espessura média de um escorregamento, considerando que a espessura das rupturas observadas na Serra do Mar seja igual a 1 m (AUGUSTO FILHO, 1993; WOLLE e CARVALHO, 1994).

Corominas (1996) afirma que a delimitação, incluindo a área fonte, pode superestimar o volume real do material mobilizado em cerca de 30 a $40 \%$, devido à incorporação de outros materiais durante a trajetória do movimento. No entanto, Polanco (2010) afirma que para o cálculo de vazão de pico, por exemplo, este parâmetro deve ser relacionado ao volume acumulado ao longo do escorregamento 
e não ao volume total de sedimentos depositado. Portanto, considerando que os escorregamentos apresentam uma espessura média $1 \mathrm{~m}$ para a Serra do Mar Paulista, como observado na literatura, e que os sedimentos provenientes destas cicatrizes podem contribuir para as corridas de detritos, acredita-se que à adoção de $50 \%$ da espessura média das rupturas dos escorregamentos é válida. 


\subsection{Parâmetros morfométricos e avaliação das corridas de detritos}

A morfometria da bacia hidrográfica pode fornecer informações do tamanho, forma e comprimento que são, elementos relevantes para a dinâmica e para o entendimento dos processos físicos e biológicos (CHAMBERLIN, 1982, FONSECA e AUGUSTIN, 2014).

Os parâmetros morfométricos inicialmente foram propostos e aplicados para a compreensão e para o entendimento dos processos hidrológicos e da evolução das bacias hidrográficas em meados da década de 1940. Atualmente tais parâmetros ou índices morfométricos vêm sendo aplicados na avaliação dos movimentos de massa, entre eles, os escorregamentos e as corridas de detritos (AUGUSTO FILHO, 1993; SCALLY et al., 2001; WILFORD et al., 2004; DEWITTE e DEMOULIN, 2005; CONFORTI et al., 2011; SILVEIRA et al., 2013; ROGELIS e WERNER, 2014).

$\mathrm{Na}$ tentativa de prever os fatores que levam e contribuem para a ocorrência dos movimentos de massa, diversas variáveis e suas combinações possíveis devem ser consideradas permitindo uma melhor avaliação destes fenômenos (JOHNSON et al., 1991; CHEN e YU, 2011; ARRUDA JUNIOR e LOPES, 2013; IPT/CPRM, 2014).

Portanto, os parâmetros morfométricos apresentados a seguir podem contribuir para o entendimento da dinâmica das corridas de detritos. Salienta-se que nesta seção não foram apresentados e descritos todos os parâmetros morfométricos utilizados nos estudos das bacias hidrográficas, mas apenas aqueles mais significativos para a compreensão das corridas de detritos, como observado na literatura (ARAYA MOYA, 1994; MASSAD et al., 1997; KANJI et al., 2008; IPT, 2002).

A relação de bifurcação $\left(R_{b}\right)$ está intimamente relacionada com os padrões de ramificação de uma rede de drenagem (HAJAM et al., 2013). Tal parâmetro, proposto por Horton (1945), é definido como a relação entre o número total de canais de uma determinada ordem $\left(N_{U}\right)$ e o número total dos canais de ordem imediatamente superior $\left(N_{U+1}\right)$ (HORTON, 1945; CHRISTOFOLETTI, 1969) (Equação 13): 


$$
R_{b=\frac{N_{u}}{N_{u+1}}} \ldots \ldots \ldots . . \text { Eq. } 13
$$

Sobre este parâmetro Christofoletti (1969) e Fonseca e Augustin (2014) destacam que para Horton tal índice estava associado ao relevo e à sua dissecação. Hajam et al. (2013) afirmam que altos valores para este índice estão associados a relevos menos permeáveis, ou seja, locais onde há menor percolação de água entre as camadas, e quando associados a altas declividades favorecem a ocorrência de fluxo superficial, indicando um potencial de ocorrência de inundações bruscas durante eventos extremos. Segundo Rickenmann e Zimmermann (1993), este tipo de cenário levaria à deflagração de corridas de detritos dentro do próprio canal de drenagem, não havendo necessidade de sedimentos provenientes das encostas.

O comprimento do canal principal é a distância do curso d'água entre a foz e a nascente e o comprimento total dos canais é o somatório de todos os canais da rede de drenagem da bacia hidrográfica (WILFORD et al., 2004; DASH et al., 2013).

O gradiente de canal $\left(G_{c}\right)$ é definido como a relação entre a diferença máxima de altitude entre a nascente e a foz com a extensão do respectivo canal (CHRISTOFOLETTI, 1969), indicando a declividade dos cursos d'água (ALVES e CASTRO, 2013) (Equação 14):

$$
G_{C=\frac{a_{\text {máx }}}{L}} \cdots \ldots \ldots \text { Eq. } 14
$$

Onde $a_{\text {máx }}$ é a altitude máxima e $L$ é o comprimento do canal principal.

O emprego deste parâmetro pode auxiliar na identificação de possíveis locais ou zonas de deposição de sedimentos, assim como, locais com potencial para serem áreas fonte de corridas de detritos.

O índice de sinuosidade $\left(I_{S}\right)$ proposto por Schumm (1963) é definido como a relação entre o comprimento verdadeiro do canal e o seu comprimento vetorial entre 
os extremos do mesmo $(d v)$, permitindo a identificação da sua sinuosidade (BRUBACHER et al., 2011; IPT/CPRM, 2014) (Equação 15):

$$
I_{s=\frac{L}{d v}} \cdots \cdots \ldots \text {. Eq. } 15
$$

De acordo com Brubacher et al. (2011) o maior índice deste parâmetro implicará em uma menor velocidade do escoamento, resultando em uma menor influência nas enchentes a jusante da sub-bacia.

O índice de força do canal (IFC) ou stream power index (SPI) é definido como a medida da força erosiva do fluxo de água fundamentado sobre a suposição de que a descarga é proporcional a área específica da bacia $\left(A_{s}\right)$ (MOORE et al., 1991; CONFORTI et al., 2011) (Equação 16):

$$
S P I=A_{s} \cdot \tan \beta \ldots \ldots \ldots . . . \text { Eq. } 16
$$

Onde $\tan \beta$ é a declividade da encosta, em graus.

Nefeslioglu et al. (2008) afirmam que este índice é um dos principais fatores que controlam os processos erosivos, influenciando diretamente a inclinação da encosta e a incisão do rio. Kakembo et al. (2009) observaram que este índice é um indicativo de energia potencial de arraste de sedimentos, portanto, áreas com alto valor deste índice tem grande potencial de erosão.

A área da bacia $(A)$ é definida como toda a área drenada projetada sobre um plano horizontal. A dimensão da área permite coletar grande quantidade de água precipitada, condicionando o volume da vazão da rede de drenagem (LANGBEIN, 1947; ROGELIS e WENER, 2014).

A densidade de drenagem $\left(D_{d}\right)$ é a relação entre o comprimento total dos canais ou rios $\left(L_{t}\right)$ com a área da bacia hidrográfica $(A)$ e serve como um indicador do desenvolvimento do sistema hidrográfico (HORTON, 1945; LANGBEIN, 1947). 
Portanto, o tempo necessário da vazão em uma determinada distância é diretamente proporcional ao comprimento do fluxo (LANGBEIN, 1974) (Equação 17):

$$
D_{d=\frac{L_{t}}{A}} \cdots \ldots \ldots \text { Eq. } 17
$$

Este índice está associado ao tempo de deslocamento da água, ao pico de vazão e ao potencial de inundação (ROGELIS e WENER,2014). Hajam et al. (2013) afirmam que o alto valor deste índice, em eventos de precipitação, reflete uma rápida resposta hidrológica $e$, inversamente, um baixo valor corresponde a uma resposta hidrológica lenta e gradual. Rodica et al. (2014) afirmam que um valor elevado deste índice resulta em uma maior fragmentação da encosta, permitindo maior infiltração e, consequentemente favorecendo a ocorrência dos processos geomorfológicos de encosta

A frequência de drenagem $\left(F_{s}\right)$ ou densidade de rios $\left(D_{r}\right)$ é denominada por Horton (1945) como o número de canais existentes em uma determinada bacia hidrográfica pela unidade de área da bacia (Equação 18):

$$
D_{r=\frac{N}{A}} \cdots \cdots \cdots \cdot \text { Eq. } 18
$$

Onde $N$ é o número total de rios.

Alves e Castro (2013) dizem que este parâmetro é significativo, pois representa o potencial hídrico de uma determinada área, em resposta, às condições litológicas, relevo, permeabilidade do material subsuperficial, capacidade de infiltração, cobertura vegetal e quantidade de precipitação resultante dos vários estágios da evolução da paisagem (HAJAM et al., 2013).

O índice de circularidade $\left(I_{c}\right)$ é a relação entre a área da bacia e a área do círculo de mesmo perímetro (ROGELIS e WENER, 2014). Expressa o quanto a bacia se aproxima da forma circular, determinando assim o tempo de concentração da bacia (IPT, 2002) (Equação 19): 


$$
I c=\frac{A}{A c} \ldots \ldots \ldots \text {. Eq. } 19
$$

Onde $A c$ é a área do círculo de perímetro igual ao da bacia em análise.

Este parâmetro permite determinar como será o comportamento do escoamento ao longo da bacia, ou seja, bacias com índices menores que 0,51 favorecem o escoamento e, inversamente, bacias com índices iguais ou superiores a 0,51 tendem a aumentar a probabilidade de cheias (ALVES e CASTRO, 2003). Ressalta-se que este parâmetro é a representação da transmissividade do escoamento superficial concentrado, que indica se o tempo de concentração da bacia é rápido ou lento (FONSECA e AUGUSTIN, 2014). Augusto Filho (1993) afirma que quanto mais próximo de 1 for este índice, maior será a condição favorável para a formação de corridas do tipo secundário (iniciadas no canal de drenagem).

O coeficiente de manutenção $\left(C_{m}\right)$, proposto por Schumm (1956) tem por objetivo fornecer a área mínima necessária para a manutenção de um metro de canal de escoamento (CHRISTOFOLETTI, 1969). Similar à densidade de drenagem, o valor desta constante auxilia na compreensão da erodibilidade da superfície ou nos fatores que atuam na erosão superficial e no desenvolvimento da rede de drenagem (SCHUMM, 1956) (Equação 20):

$$
C_{m}=\frac{1}{D d} * 1000 \ldots \ldots \ldots . \text { Eq. } 20
$$

Onde, $D d$ é o valor da densidade de drenagem $\left(\mathrm{m}^{2}\right)$.

A relação de relevo $\left(R_{r}\right)$ é definida como a relação entre a diferença altimétrica de uma bacia e a maior extensão da mesma, medida paralelamente a linha de drenagem principal (SCHUMM, 1956) e pode ser considerado como um indicador do intenso processo erosional que atua nas encostas da bacia (SCHUMM, 1956; HAJAM et al., 2013) (Equação 21): 


$$
R_{r=\frac{\Delta a}{L} \ldots \ldots \ldots . . . E q .} 21
$$

Onde, $\Delta a$ é a amplitude altimétrica e $L$ é o comprimento do rio principal.

Este índice pode ser aplicado, como proposto por Corominas (1996), Rickenmann (1999), Hattanji e Moriwaki (2009) para descrever a distância, a trajetória e a magnitude da corrida de detritos e é definida por Chen e Yu (2011) (Equação 22) como:

$$
R=H / D \ldots \ldots \ldots \text { Eq. } 22
$$

Onde $H$ é a diferença de elevação entre o ponto inicial e ponto final da deposição do movimento de massa e $D$ é a distância horizontal. Rickenmann (1999) e Chen e Yu (2011) afirmam que este índice pode ser usado para descrever o deslocamento da corrida de detritos entre a origem do escorregamento, ponto de ruptura, até a sua deposição.

O índice de umidade topográfica (IUT) descreve o efeito da topografia sobre o local e o tamanho das áreas fontes saturadas necessárias para a geração do fluxo superficial (runoff) (CONFORTI et al., 2011), e pode ser usado para estimar a umidade do solo, profundidade da coluna d'água e simulações hidrológicas (MUKHERJEE et al., 2013). Este índice baseia-se sobre a suposição de que a condutividade hidráulica do solo diminui exponencialmente com a profundidade do solo, de modo que o fluxo limita-se a uma camada superficial (WILSON e GALLANT, 2000).

O índice de umidade topográfica combina a área de contribuição de um determinado ponto e a declividade da encosta sendo empregado para quantificar o controle topográfico sobre os processos hidrológicos (BEVEN e KIRKBY, 1979; QUINN et al., 1991; SORENSEN et al., 2006;), bem como, para identificar a 
ocorrência dos movimentos de massa (NEFESLIOGLU et al., 2008; CHEN e YU, 2001) (Equação 23):

$$
I U T=\ln \left(\frac{A_{S}}{\tan \beta}\right) \ldots \ldots \ldots . . . E q .23
$$

Onde $A_{s}$ é a área específica da bacia $\left(\mathrm{m}^{2}\right)$ e $\tan \beta$ é a declividade da encosta em graus. 


\section{3. ÁREA DE ESTUDO: Caraguatatuba, SP}

A Serra do Mar é um conjunto de escarpas festonadas que configura a costa leste do Brasil, desde o estado de Santa Catarina até o Rio de Janeiro, abrangendo as regiões Sul e Sudeste. Sua direção geral é E-NE, acompanhando a orientação das estruturas do Escudo Atlântico (HASUl et al., 1994; ALMEIDA e CARNEIRO, 1998). No estado de São Paulo, este compartimento insere-se na unidade morfoescultural do Planalto Atlântico sendo sustentado basicamente por granitos, gnaisses, migmatitos, micaxistos e apresentando relevo bastante dissecado, com encostas íngremes e alta densidade de drenagem associadas com as falhas, fraturas e contatos litológicos (ROSS e MOROZ, 1997).

A Serra do Mar em Caraguatatuba, Litoral Norte do Estado de São Paulo, é caracterizada por duas subunidades: Serrania Costeira e Baixadas Litorâneas. A Serraria Costeira representa o front da serra, com altitudes de até 1200 metros, apresentando feições como escarpas festonadas, espigões, serras alongadas, morros paralelos e morros isolados. As Baixadas Litorâneas são representadas por relevos baixos com altitudes inferiores a 70 metros, apresentando elevações que separam pequenas planícies e enseadas, na qual se formaram as praias de bolso, dentro do contexto de costa sinuosa e em submersão (CRUZ, 1974; HASUl et al., 1994).

Cruz (1974) compartimentou o relevo do município de Caraguatatuba em três planalto, escarpa e planícies litorâneas (Figura 10). O substrato rochoso do planalto e da escarpa é composto por granitos-gnaisse, migmatitos e micaxistos (IPT, 1987; Colangelo, 2012), enquanto falhas, zonas de cisalhamento, fraturas e grandes domínios de rochas supracrustais condicionam lineamentos maiores e segmentos locais da rede de drenagem (ALMEIDA e CARNEIRO, 1998). 


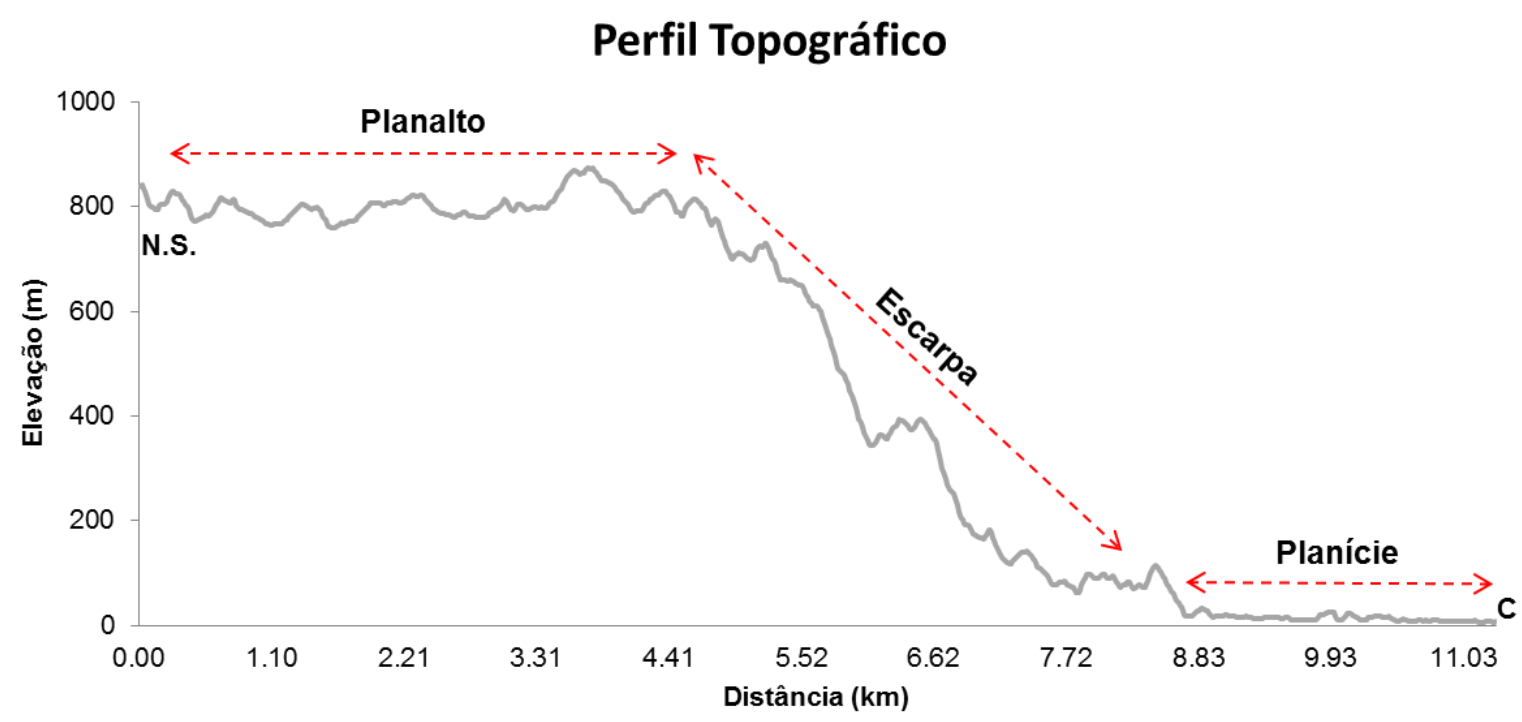

Figura 10: Perfil topográfico elaborado por meio do MDT, entre os municípios de Natividade da Serra e Caraguatatuba, em São Paulo, perfazendo uma secção da bacia do rio Santo Antônio.

O planalto apresenta, de forma predominante, relevo mamelonizado com altitudes entre 800 a 900 e acima de $900 \mathrm{~m}$, com amplitude topográfica variando entre 20 a 200m (até 400m em alguns pontos), presença de escarpas retilinizadas e com espessos mantos de regolito. A rede de drenagem nas cabeceiras, em resposta aos morros mamelonizados é do tipo dendrítica, passando a retilínea, retangular e em treliça em resposta ao arranjo estrutural, principalmente nos médios e baixos cursos (CRUZ, 1990; ROSS e MOROZ, 1997; COLANGELO, 2012).

As escarpas são áreas caracterizadas pela influência estrutural, com predominância de encostas do tipo côncavo-convexo, íngremes nas partes mais altas deste compartimento $\left(>22^{\circ}\right)$, com ocorrência de baixos níveis e patamares intermediários e rampas de desgastes, com encostas mais suaves (CRUZ, 1974; IPT, 1987). Neste compartimento a amplitude topográfica chega até $800 \mathrm{~m}$, com extensos perfis retilinizados (CRUZ, 1990; COLANGELO, 2012) e ocorrem sistemas de drenagens que formam pequenas bacias em forma de anfiteatro. Os vales, como resposta ao forte controle litológico e estrutural, apresentam formato de "V", sendo profundamente entalhados e interrompidos por soleiras, caracterizando extrema juventude do relevo (CRUZ, 1974; IPT, 1987; ALMEIDA e CARNEIRO, 1998).

A formação dos corpos de colúvio/tálus dá-se pela remoção e deslocamento dos solos, principalmente na parte superior por meio dos movimentos de massa e/ou 
por escoamento superficial, tendo na época da estação chuvosa uma remoção mais intensa (IPT, 1987; CRUZ, 1974). Segundo Cruz (1974) é possível observar uma superposição de camadas correspondentes a diferentes épocas de deposição.

Nas áreas de deposição (planícies litorâneas) são encontradas as depressões úmidas como solos húmicos, terraços fluviais e colúvio-aluviais, bem como, terraços e taludes de detritos coluviais de pé de encosta. A drenagem nestes locais segue o traçado condicionado à evolução e progressão dos depósitos (CRUZ, 1974).

Os solos apresentam-se de forma irregular nas escarpas, sendo mais espessos nas áreas de cumes e variando a espessuras delgadas ao longo das encostas, consistindo, em sua maior parte, de solos de alteração capeados por fina camada de colúvio (IPT, 1987).

Para uma determinada seção na bacia do rio Santo Antônio, na Serra de Caraguatatuba, Cruz (1974) examinou os perfis mais representativos das escarpas por meio das sondagens cedidas pela Centrais Elétricas de São Paulo (CESP) e observou que os resultados acusaram diferentes profundidades de alteração para as rochas gnáissicas ali presentes. Os movimentos de massa ocorrem, segundo Cruz (1974) nas zonas de decomposição da rocha ou rocha pouca decomposta, com espessuras entre 7,15 e $55 \mathrm{~m}$ e 8,10 e 16,50 m, respectivamente. Nestas zonas os materiais apresentam-se fissurados, fragmentados e por vezes, muito alterados, constituídos predominantemente por frações de areia (CRUZ, 1974).

O manto de alteração e/ou o colúvio apresentam espessuras entre 3 a 44 m constituídos basicamente por materiais arenosos, areno argiloso e argilo arenoso. Devido à condição topográfica e a estrutura do material acima da rocha sã, o nível freático apresenta oscilações localizando-se próximo a superfície quando da fina camada do manto de alteração ou colúvio até mesmo em grandes profundidades, localizado no contato entre a zona de decomposição e a zona da rocha pouco alterada (CRUZ, 1974). Neste estudo, o autor observou que em determinadas localidades onde as encostas são mais íngremes, o nível freático pode alcançar a rocha sã.

A oscilação do nível freático nestas encostas está de acordo com as variações de precipitação sazonais e diárias, segundo Cruz (1974). Na maior parte 
do litoral do estado de São Paulo são observadas características de clima tropical, sem estação seca bem definida, com diminuição dos volumes de precipitação durante o inverno e o aumento deste volume no verão (SELUCHI e CHOU, 2009; SANTOS e GALVANI, 2012). O efeito sazonal do regime pluviométrico, no Litoral Norte, é decorrente da influência das massas tropicais e sistemas frontais, que somados à influência topográfica, condicionam maiores valores de precipitação (SANT-ANNA NETO, 1994; BARBOSA, 2007; PELLEGATTI e GALVANI, 2010).

A vegetação na Serra do Mar caracteriza-se por uma floresta alta e com vários estratos, latifoliada, tropical, sub-úmida a superúmida. O porte arbóreo varia entre 25 a $30 \mathrm{~m}$ de altura e devido à sua distribuição escalonada nas encostas, os troncos podem apresentar entre 1 e $3 \mathrm{~m}$ de diâmetro e copas mais densas e largas (QUEIROZ NETO e OLIVEIRA, 1964; IPT, 2002).

A precipitação média anual em Caraguatatuba é de 1784 mm (SANTOS e GALVANI, 2012). Tavares et al. (2004) apontam que, de forma geral, o litoral norte possui alta variabilidade de precipitação, principalmente entre os meses de fevereiro e março. Porém, Caraguatatuba apresenta uma menor variabilidade, em relação aos demais municípios, devido a sua posição geográfica, mais recuada, que ameniza o efeito na relação da circulação atmosférica com a orografia, resultando nas sombras de chuvas (TAVARES et al., 2004).

Cruz (1974) caracterizou o litoral norte como uma das áreas mais úmidas do país, devido às águas superficiais abundantes e rede de drenagem densa e contínua, somado ao regime de chuvas torrenciais, de alta intensidade, com máximas entre 100 a $200 \mathrm{~mm}$ em 24 horas e 40 a $50 \mathrm{~mm}$ por hora e que, quando, associadas às escarpas da Serra do Mar, resulta em sérios problemas de dinâmica de vertente.

Um exemplo desta dinâmica diz respeito às precipitações, ocorridas nos meses anteriores a março de 1967 e nos dias 17 e 18 deste mesmo mês que alcançaram valores de $260 \mathrm{~mm}$ e $324,8 \mathrm{~mm}$, respectivamente (Figura 11). Consequentemente, ocorreu neste período um evento de grande magnitude com o registro de inúmeros processos de movimentos de massa nas escarpas da Serra do Mar, entre eles, os escorregamentos e as corridas de detritos (Figuras 12 e 13). 

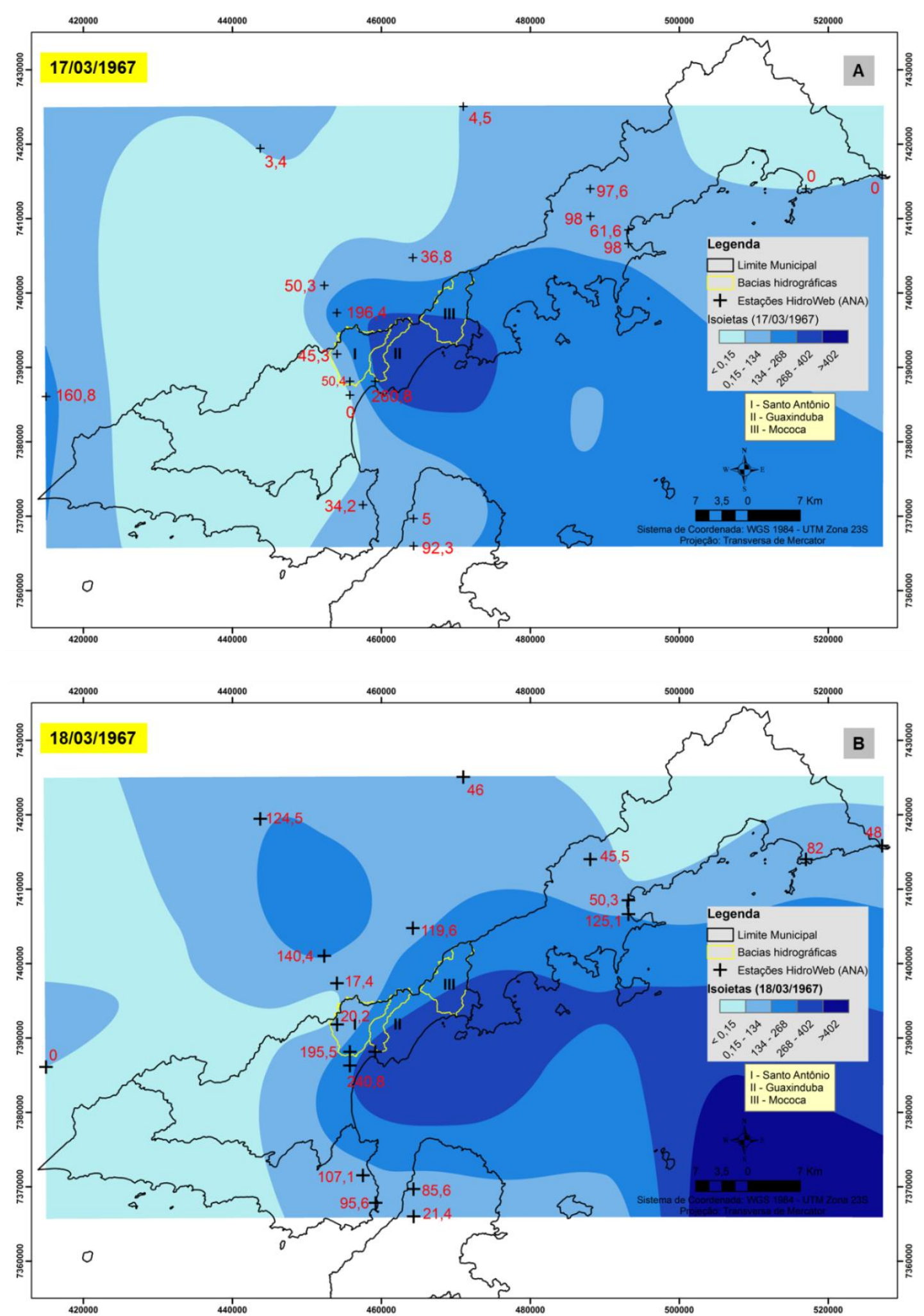

Figura 11: Mapa de isoietas ${ }^{2}$ para o evento de 1967. Os maiores valores de precipitação ocorreram sobre as bacias dos rios Santo Antônio e Mococa. Fonte dos dados: HidroWeb - ANA e Cepagri Unicamp.

\footnotetext{
${ }^{2} \mathrm{~A}$ interpolação em função de base radial (spline), interpola uma superfície a partir de pontos de varredura (estações pluviométricas), utilizando-se de uma técnica de curvatura mínima (ESRI, 2010).
} 


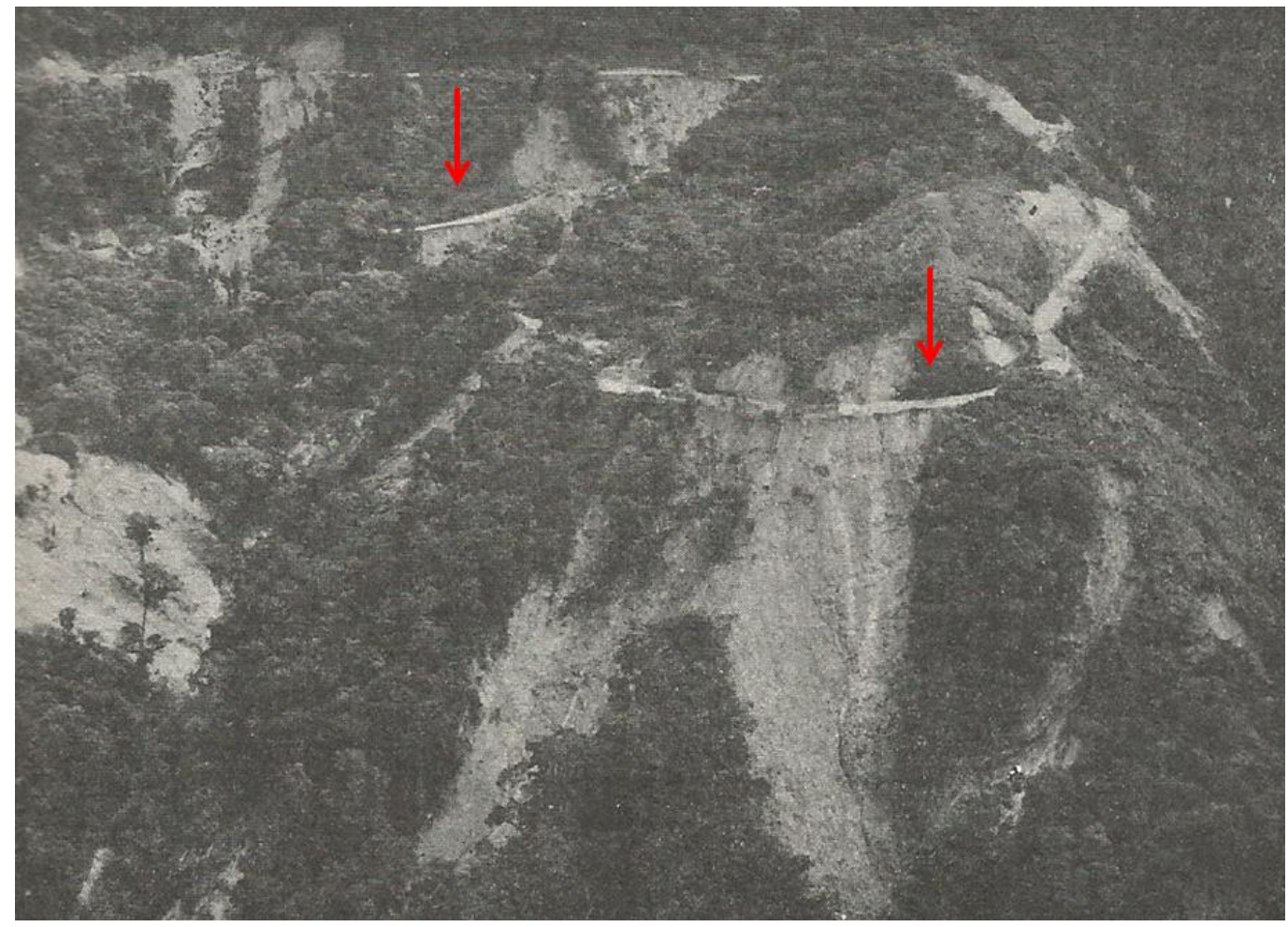

Figura 12: Cicatrizes de escorregamentos nas encostas da Serra do Mar, que atingiram a rodovia dos Tamoios (setas vermelhas) interrompendo a circulação de veículos em determinados trechos. Fonte: Cruz (1974).

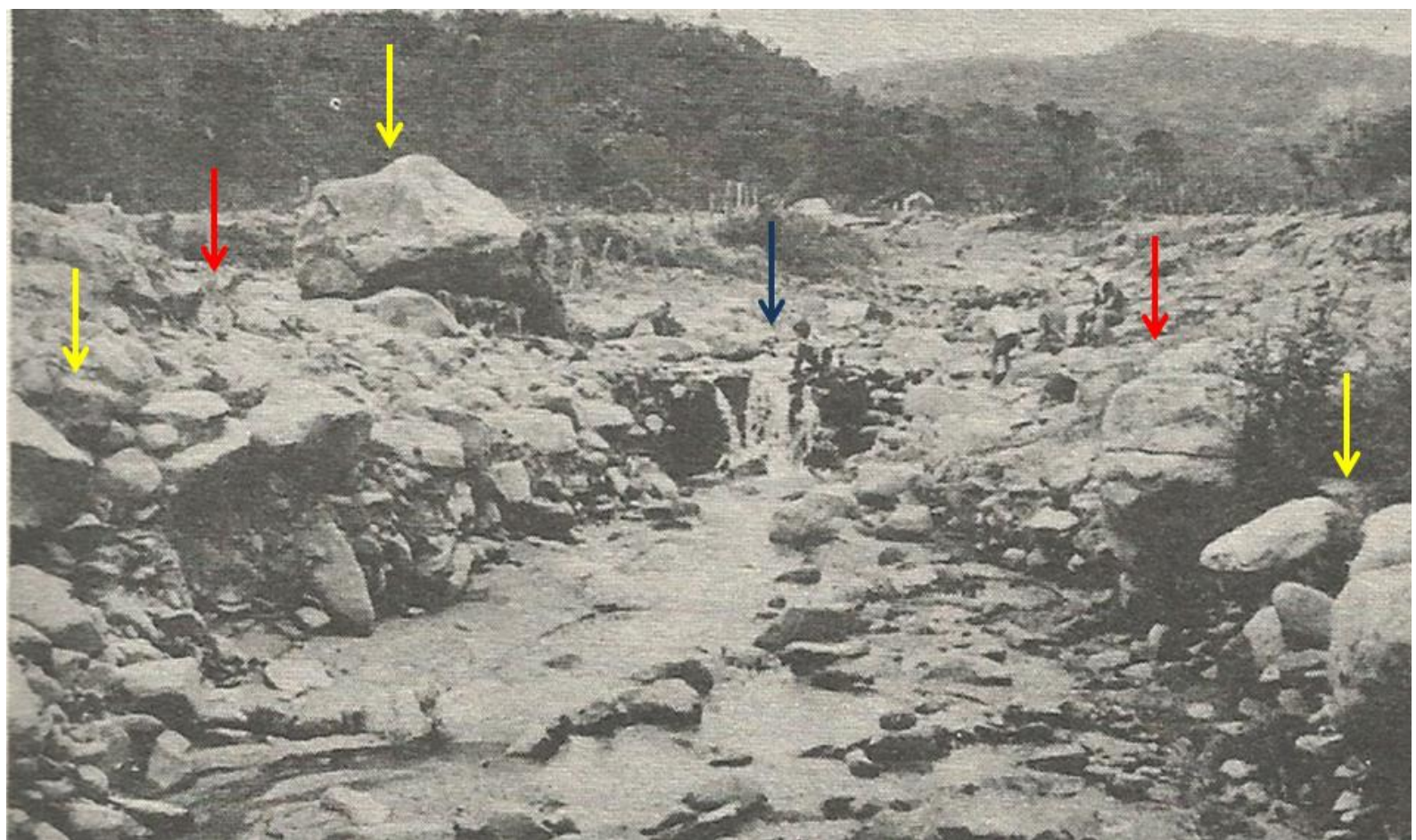

Figura 13: Arranjo e deposição dos blocos de tamanhos variados (setas amarelas) sobre as margens do canal (setas vermelhas). A seta azul indica a localização do rio. Fonte: Cruz (1974). 
Cruz (1974) relatou que os rios perderam seu leito original, vagando em uma planície de lama. A estrada da serra desapareceu impossibilitando até mesmo o reconhecimento da sua trajetória e em outras localidades as vias também foram atingidas por escorregamentos, dificultando o acesso aos bairros (CRUZ, 1974).

Para este evento, estimou-se um grande volume de sedimentos mobilizados, além disso, contabilizou-se que aproximadamente 30 mil árvores tenham descido as encostas e morros, se espalhando pela cidade e resultando na destruição de 400 casas (Figuras 14 e 15), e a ocorrência de 120 mortes de acordo com registros oficiais (CRUZ, 1974; IPT, 1987).

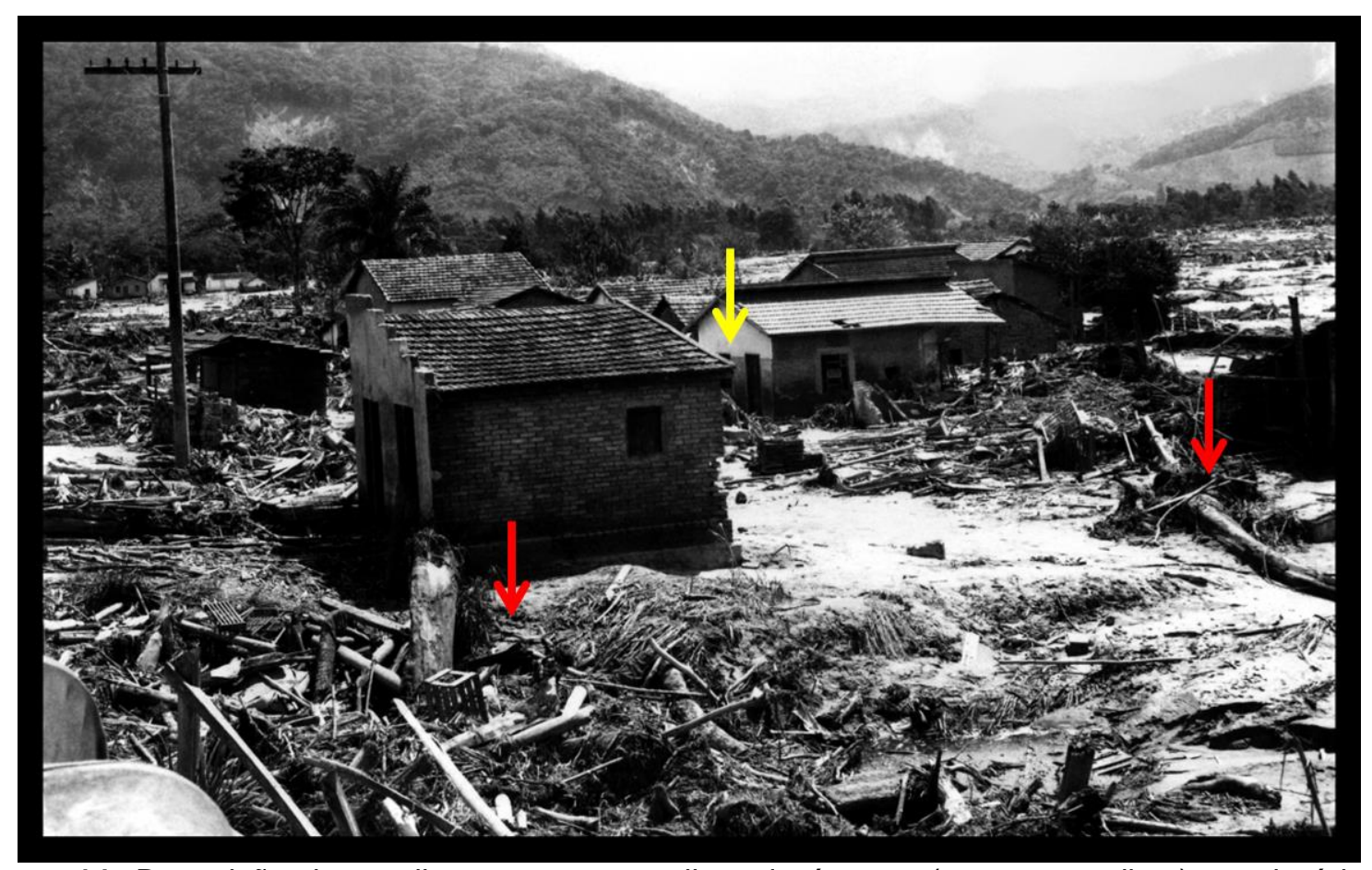

Figura 14: Deposição de entulhos, troncos e galhos de árvores (setas vermelhas) na planície da bacia. A altura da coluna da corrida de detritos pode ser observada pela seta amarela, indicando a magnitude do evento. Fonte: Arquivo Público do município de Caraguatatuba. 


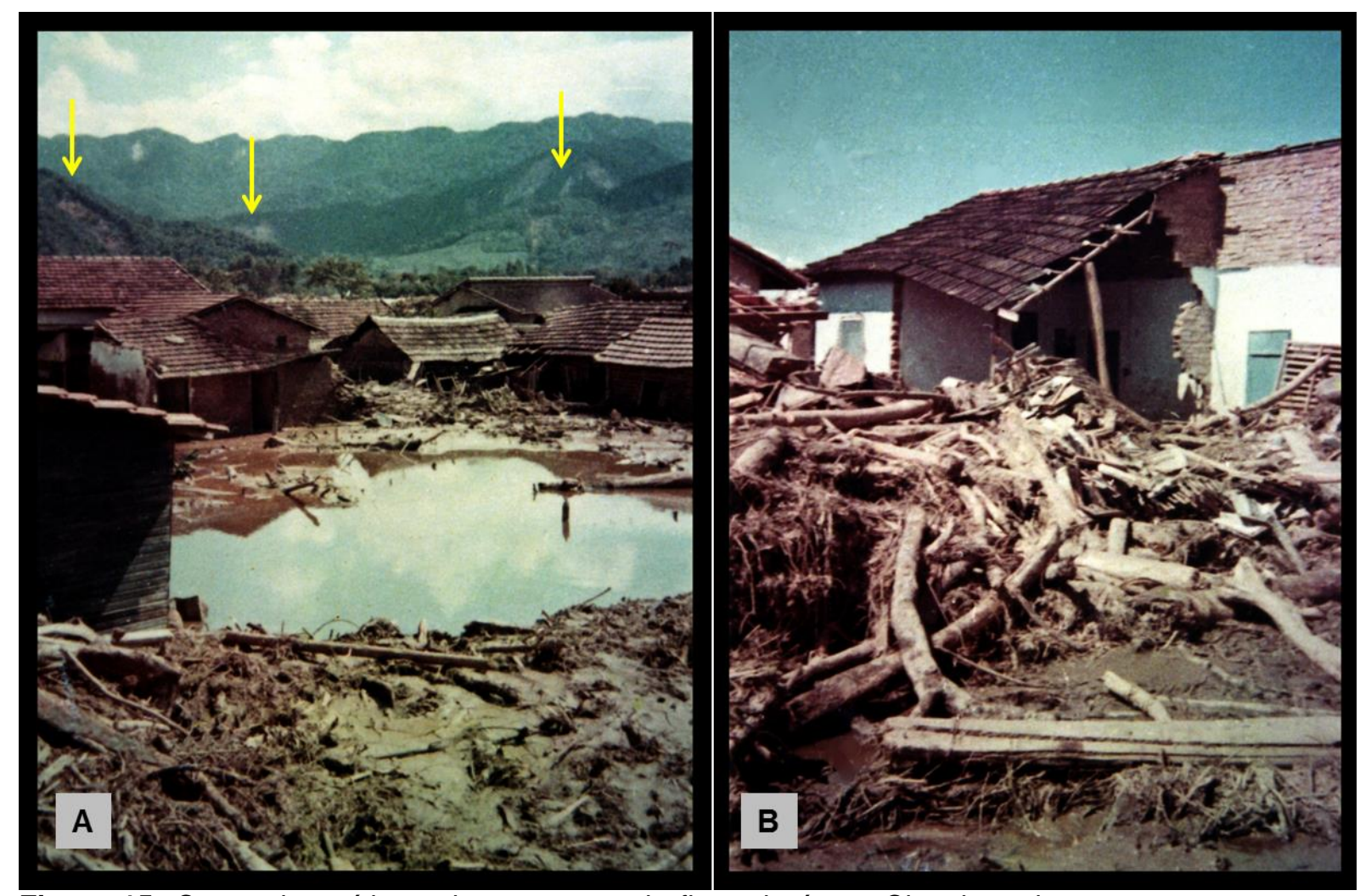

Figura 15: Casas destruídas pela passagem do fluxo de água. Cicatrizes de escorregamentos nas encostas da Serra do Mar (setas amarelas) (a). Observa-se que as casas serviram de barragem para a água e para os materiais transportados pela corrida de detritos (b). Fonte: Arquivo Público do município de Caraguatatuba.

O critério que fundamentou a escolha das bacias a serem analisadas foi a ocorrência de movimentos de massa generalizados, principalmente os escorregamentos e, consequentemente a deflagração das corridas de detritos para o evento de 1967. A magnitude do evento, o comportamento diferencial destes processos ao longo das suas encostas e nas redes de drenagem, somado a disponibilidade de material cartográfico e informações aerofotogramétricas permitiram, neste contexto, escolher as bacias do rio Santo Antônio, rio Guaxinduba e rio Mococa (Figura 16). Estas bacias deflagraram corridas de detritos com magnitudes distintas. Ressalta-se que até os dias de hoje é possível observar as cicatrizes dos escorregamentos, bem como, o crescimento urbano sobre os depósitos das corridas. 


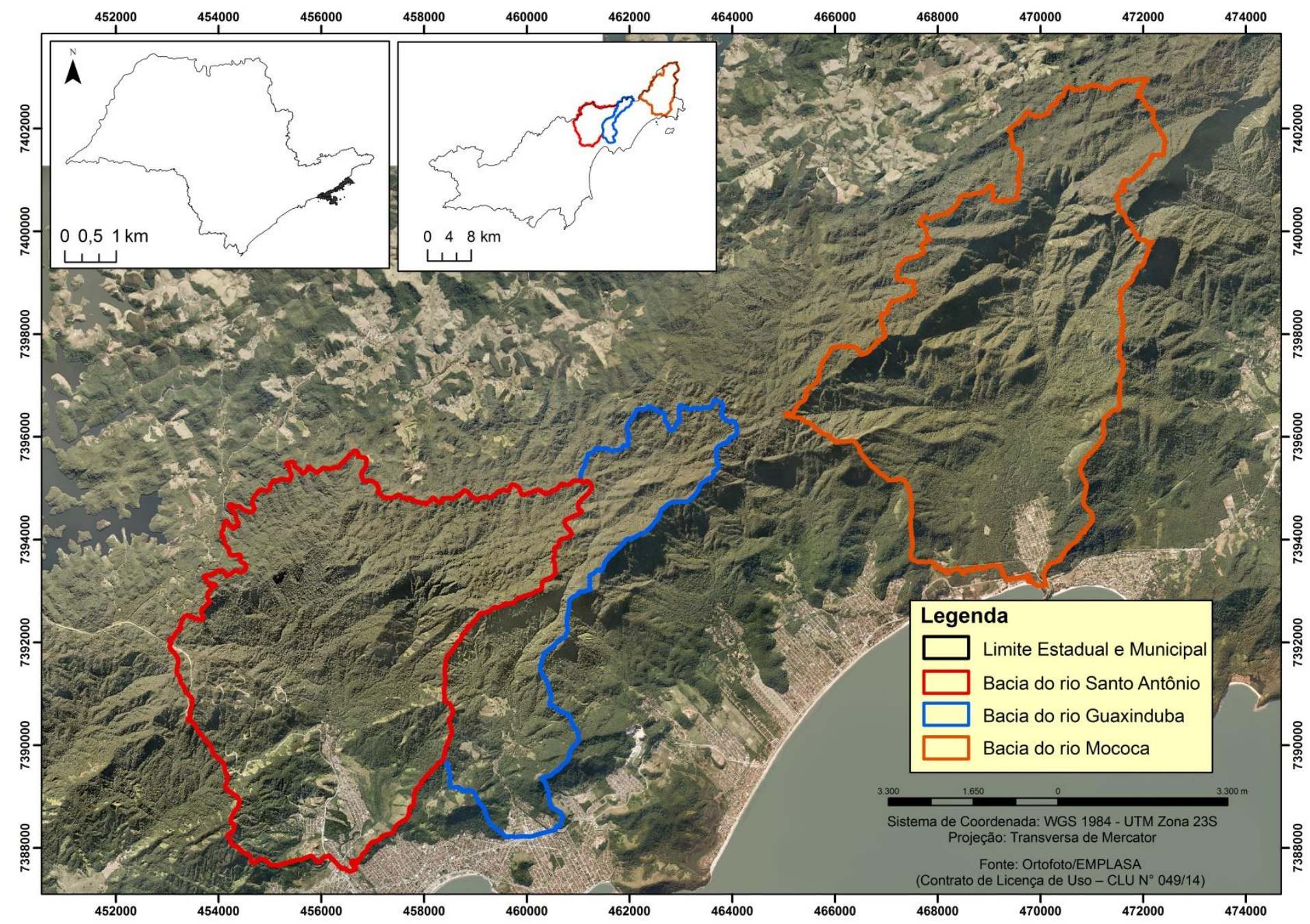

Figura 16: Mapa de localização das bacias dos rios Santo Antônio, Guaxinduba e Mococa, em Caraguatatuba-SP. 


\section{MATERIAIS E MÉTODOS}

Para alcançar o objetivo desta pesquisa - avaliar o potencial de geração de corridas de detritos em escala de bacia hidrográfica na Serra do Mar paulista, no Litoral Norte do estado de São Paulo - algumas etapas foram estabelecidas (Figura 17). A primeira refere-se à identificação das áreas fontes (escorregamentos) (4.1). A segunda etapa consiste no mapeamento e identificação dos depósitos de corridas de detritos (4.2). A terceira etapa envolve a identificação dos parâmetros e dos índices morfométricos e morfológico (4.3). Por último, procedeu-se uma sistematização (hierarquização) do potencial de geração a corridas, conforme os índices morfométricos e morfológico e os mapas dos depósitos (4.4 e 4.5).

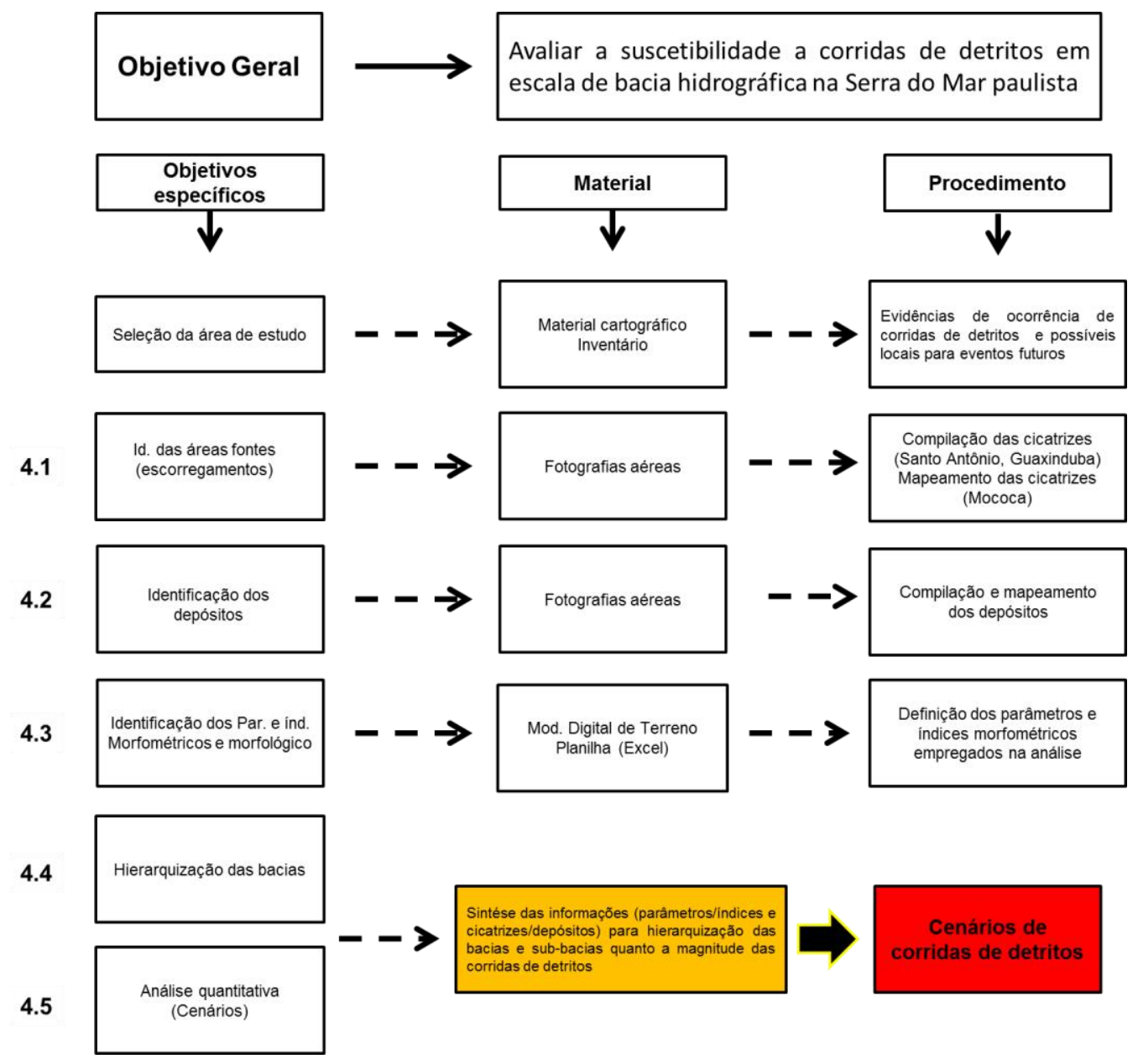

Figura 17: Fluxograma das etapas metodológicas da pesquisa. 


\subsection{Identificação das áreas fonte nas encostas}

As cicatrizes foram mapeadas utilizando-se as fotografias aéreas disponibilizadas pelo Instituto de Pesquisas Tecnológicas (IPT) referente ao ano de 1972, seis anos após o evento de 1967; e ortofotos de 2010/2011 disponibilizadas pela Empresa Paulista de Planejamento Metropolitano (Emplasa) ${ }^{3}$, ambas em escala de 1:25.000, com resolução espacial de $1,5 \mathrm{~m}^{2}$ e $1 \mathrm{~m}^{2}$, respectivamente. Adicionalmente, exceto para a bacia do rio Mococa, foi também utilizado o mapa de cicatrizes gerado por Fúlfaro et al. (1976), para o evento de 1967.

A identificação e mapeamento destes processos foram pautados na análise visual sobre as imagens, considerando os seguintes critérios: a tonalidade, pois reflete os locais onde ocorreram estes processos distinguindo-se daqueles locais onde não houve a ocorrência do processo; o tamanho, pois corresponde a extensão e dimensão da área afetada; e a posição topográfica destes processos. 0 mapeamento foi realizado em escala de trabalho de 1:2.000 minimizando assim a perda de qualidade na resolução da imagem. Assume-se, também, que a escala adotada limita a identificação de pequenas cicatrizes nas encostas analisadas (Figuras 18 e 19).

\footnotetext{
${ }^{3}$ Modelo digital de superfície de alta resolução do Levantamento Aerofotogramétrico em escala 1:25.000 (2010/2011) cedidas pela Empresa Paulista de Planejamento Metropolitano S/A - Emplasa (Contrato de Licença de Uso - CLU No 049/14).
} 

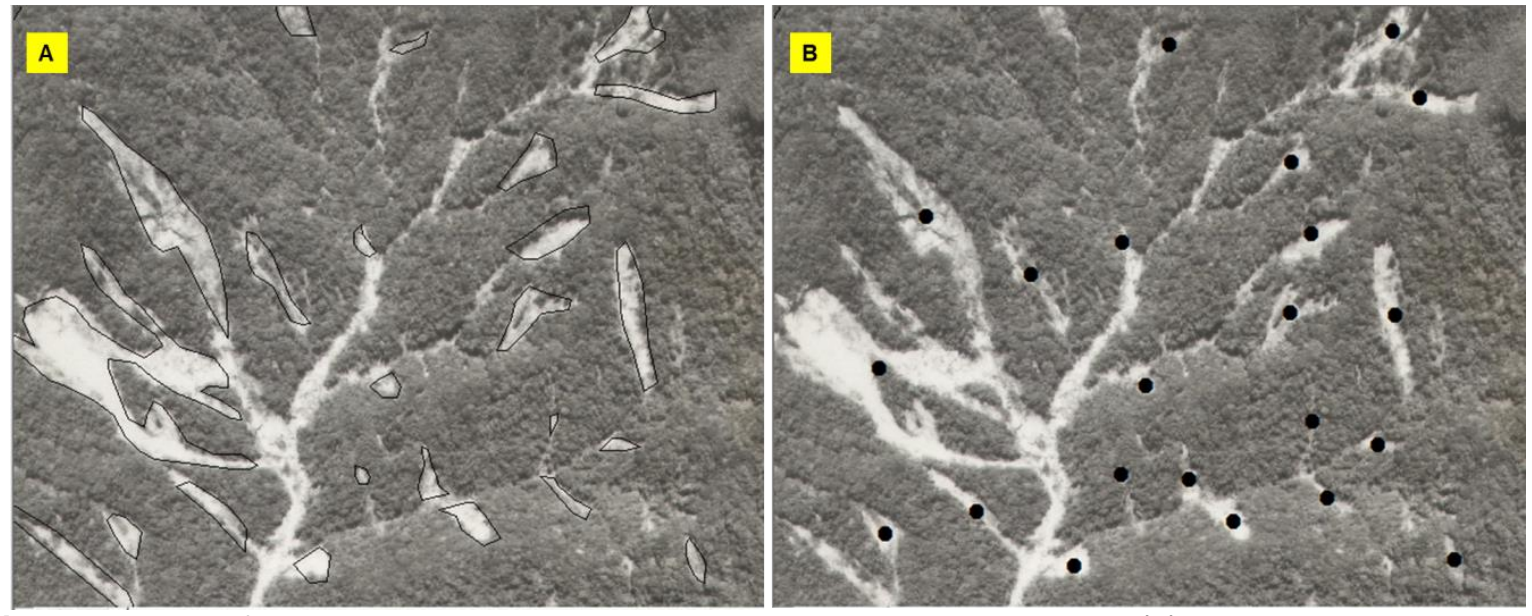

Figura 18: Identificação e delimitação das cicatrizes dos escorregamentos (a). Pontos gerados a partir da conversão do limite de cada cicatriz (b). Tais informações foram utilizadas para estimar o volume e a densidade de escorregamento por bacia e sub-bacia.
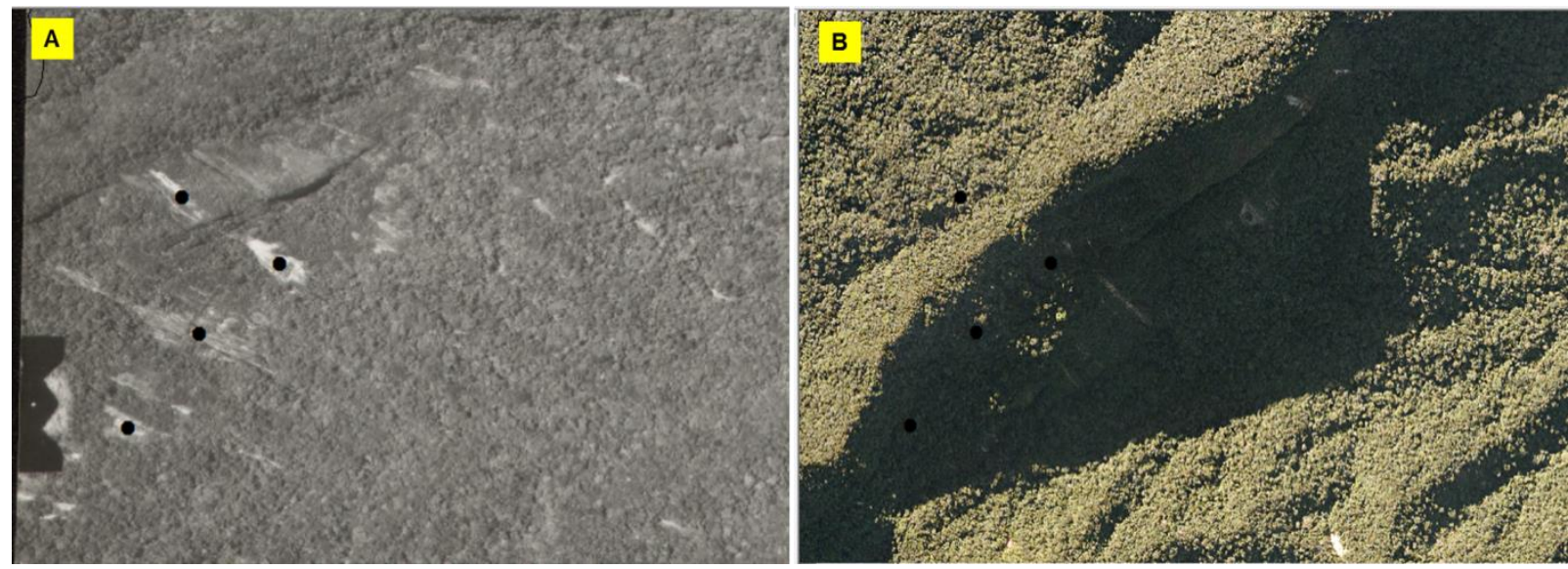

Figura 19: A identificação das cicatrizes na fotografia aérea (a) foi prejudicada pela presença de sombras na ortofoto (b), dificultando a sua delimitação, visto que a ortofoto serviu como referência para o georreferenciamento da fotografia aérea.

No mapeamento foram utilizados pontos e polígonos para obter a densidade dos escorregamentos por bacia e sub-bacia e o volume de sedimentos decorrentes destes processos, possibilitando quantificar a contribuição de cada cicatriz. Existem algumas incertezas do emprego deste método nos resultados, pois segundo Cannon (1989) e Brardinoni et al. (2002), o valor do volume pode ser superestimado ou subestimado e pode haver discrepância na delimitação do processo, necessitando, assim, a confirmação e a delimitação destas áreas em campo. Contudo, isso não invalida as análises a priori, pois em áreas de difícil acesso ou até mesmo em 
estudos de inventários destes processos, a fotointerpretação pode contribuir para o entendimento destes fenômenos.

A partir do mapeamento das cicatrizes, o próximo passo foi calcular o volume de material mobilizado em cada cicatriz. Para isso, utilizou-se como base o trabalho de Augusto Filho (1993) levando-se em consideração a delimitação da cicatriz e a espessura média das rupturas observadas. Assumiu-se a delimitação total da área afetada pelo escorregamento, não distinguindo o processo deflagrado (translacional ou rotacional) e adotando-se então o valor de $0,5 \mathrm{~m}$, o qual corresponde à espessura média de ruptura do processo (Equação 24):

$$
V_{c}=A_{c} \cdot 0,5 \ldots \ldots \ldots . \text { Eq. } 24
$$

Onde $V_{c}$ é o volume da cicatriz $\left(\mathrm{m}^{3}\right), A_{c}$ é a área da cicatriz $\left(\mathrm{m}^{2}\right)$, e 0,5 m é a espessura da ruptura.

Limitações em relação ao registro e à identificação destas feições na fotografia aérea foram observadas ao longo da confecção do mapa de cicatrizes. Devido à falta de objetos facilmente identificáveis em ambas as imagens (por exemplo, vias de circulação, edificações), o georreferenciamento das fotografias aéreas, principalmente no contato escarpa-planalto, apresentou pequeno deslocamento em relação à ortofoto. Consequentemente, a identificação de algumas cicatrizes de escorregamentos foi comprometida. Outra ressalva diz respeito às sombras presentes na ortofoto que comprometeram a identificação das cicatrizes localizadas próximas aos paredões rochosos. 


\subsection{Identificação dos depósitos de corridas de detritos}

A delimitação dos depósitos das corridas de detritos foi feita pela sobreposição do mapa geomorfológico (CRUZ, 1974), em escala de 1:40.000, e das fotografias aéreas (1973) e ortofotos (2010/2011). Para as bacias dos rios Santo Antônio e Guaxinduba também foram utilizados os depósitos mapeados por Cruz (1974) e por Dias (2014). Ressalta-se que estes materiais não contemplam a área da bacia do rio Mococa.

A identificação dos depósitos ou zonas de arraste (passagem) foi realizada para as três bacias complementando as observações realizadas por Cruz (1974) e por Dias (2014). O reconhecimento do depósito nos canais de drenagem e nas áreas planas observadas nas fotografias de 1973 deu-se pela tonalidade (em cor esbranquiçada), largura do canal e por sua deposição em zonas com declividades inferiores a $15^{\circ}$ (VANDINE, 1986).

O cálculo do volume de sedimentos das zonas de deposição e de arraste fundamentou-se nas observações de campo realizadas por Conq et al. (2015), na bacia do córrego do Príncipe, Teresópolis (RJ). Estes autores observaram que a corrida de detritos formou uma zona de deposição com espessura a partir de $2 \mathrm{~m}$. Observações a respeito deste valor de espessura também foram apontadas por Augusto Filho et al. (2005) para uma determinada região da Serra do Mar, próximo a Cubatão (SP). Os autores, determinaram o volume de sedimentos oriundos das corridas de detritos em sub-bacias localizadas no sistema viário Anchieta Imigrantes. Os depósitos, pontos iniciais e finais, foram determinados por meio do perfil da declividade do canal, utilizando-se de um mapa de declividade elaborado em ambiente SIG. Portanto, a estimativa de volume dos depósitos é dada pela Equação 25:

$$
V_{d}=A_{d} \cdot 2,0 \ldots \ldots \ldots . . \text { Eq. } 25
$$


Onde $V_{d}$ é o volume do depósito $\left(\mathrm{m}^{3}\right), A_{d}\left(\mathrm{~m}^{2}\right)$ é a área do depósito, e 2,0 m é a espessura média da deposição.

$\mathrm{Na}$ pesquisa aqui apresentada não houve medições diretas em campo dos depósitos das corridas de detritos, contudo, utilizou-se dos materiais elaborados por Cruz (1974) e por Dias (2014). Cruz (1974), por meio de fotografias aéreas da Força Aérea Brasileira, em escala de 1:25.000, executadas após o evento de Caraguatatuba (Figura 20).

Conforme Cruz (1974), a fotointerpretação permitiu identificar e delimitar as alterações ocorridas em determinadas regiões do município. Segundo a autora, tais análises permitiram realizar observações a respeito, por exemplo, do alargamento do rio Santo Antônio de 10-20 m para 60-80 m formando barrancas de erosão; a formação de um canal anastomosado devido ao entulhamento do canal, invadindo o seu antigo leito; a destruição da ponte na entrada sul e destruição parcial das áreas de loteamentos de beira-mar, recobrindo as ruas da cidade por uma camada de lama superior a 0,80 m (CRUZ, 1974). 

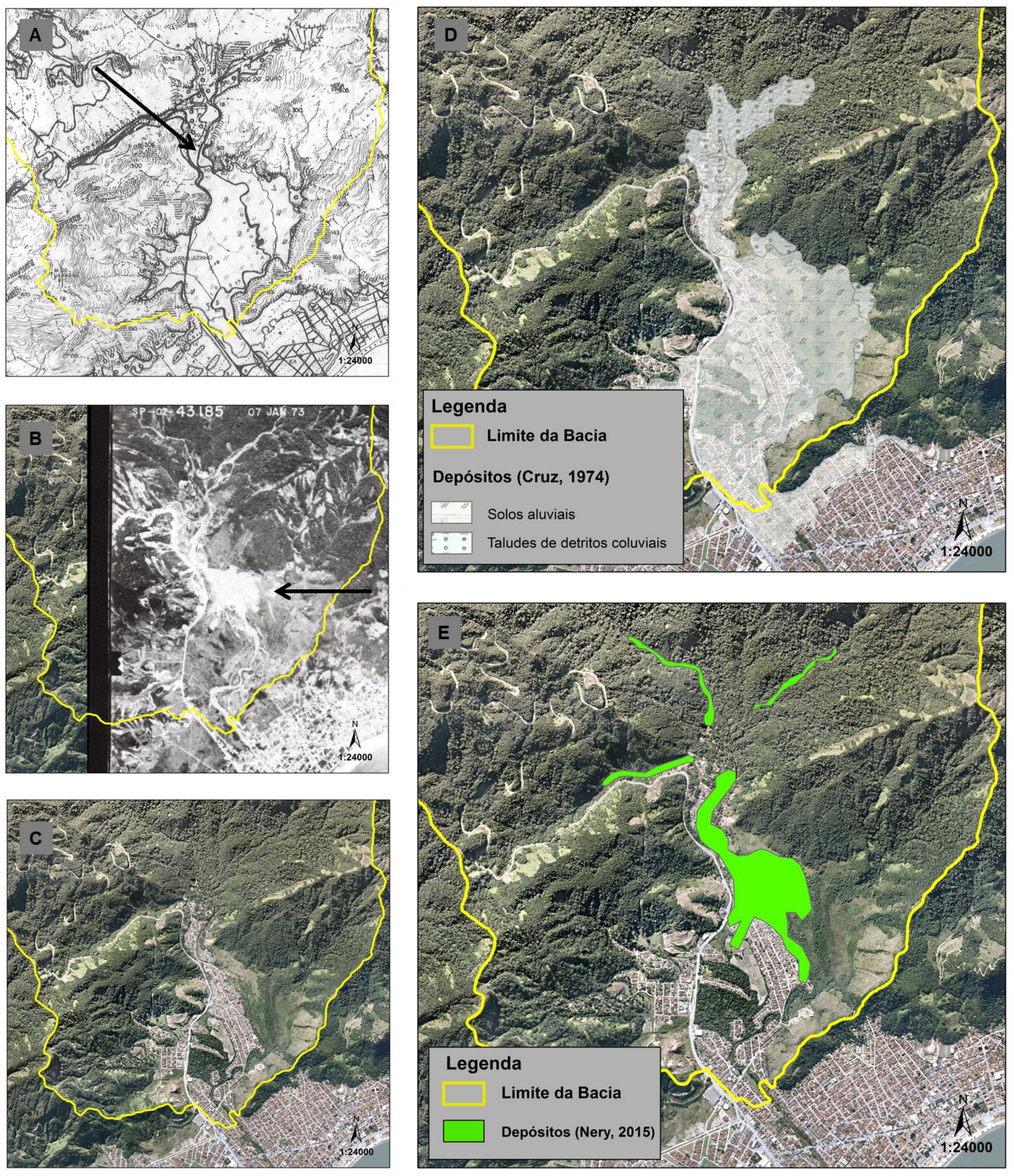

Figura 20: Mosaico das imagens utilizadas para o reconhecimento dos depósitos ou zona de arraste: (a) mapa geomorfológico (Cruz, 1972); (b) fotografia aérea (IPT, 1973); (c) ortofoto (Emplasa, 2010/2011); (d) sobreposição dos depósitos obtidos por meio da carta geomorfológica; e (e) sobreposição dos depósitos ou zonas de arraste obtido via fotografia aérea. As setas (em preto) indicam a localização dos depósitos mapeados e observados nas imagens (a e b). 
Dias (2014), com o intuito de identificar a magnitude das corridas de detritos, tendo como base o trabalho de Cruz (1974), em Caraguatatuba (SP), mapeou os depósitos das corridas de detritos nas bacias dos rios Guaxinduba e Massaguaçu levando em consideração a sua localização, as características dos depósitos (diâmetros dos blocos), a distância em relação aos cursos d'água $(50 \mathrm{~m})$, bem como a proximidade das encostas e as cotas onde se localizaram estes depósitos (Figura 21).
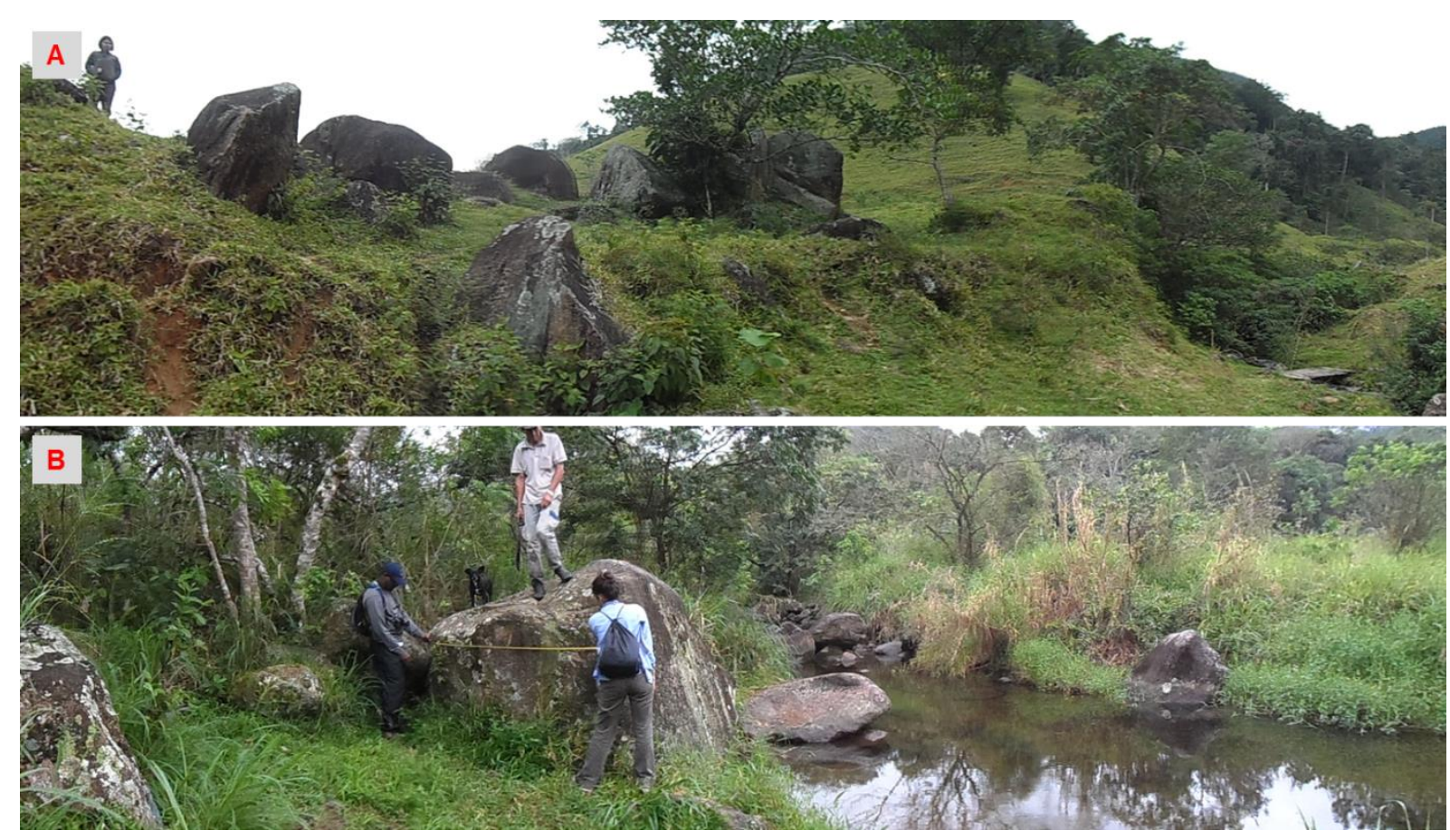

Figura 21: Encosta com presença de blocos próximos a um afluente do rio Guaxinduba (a). Medição do diâmetro dos blocos depositados em um determinado trecho nas margens do rio Guaxinduba (b). Fonte: Vivian C. Dias.

O uso de diferentes tipos de imagens pode auxiliar e minimizar a lacuna referente às não observações de campo, permitindo estimar o volume do depósito a partir da sua geometria na imagem como, por exemplo, na fotografia aérea (VAN STEIJN, 1996; HELSEN et al., 2002; JAKOB e FRIELE, 2010). Por outro lado, algumas considerações a respeito do emprego destas imagens devem ser pontuadas: 
- O intervalo de tempo entre as imagens pode ser uma limitação dificultando a identificação dos processos, principalmente no reconhecimento dos depósitos e a trajetória das corridas de detritos (PETERSON et al., 1993);

- A qualidade da imagem, bem como, a tonalidade esbranquiçada, pode induzir a delimitação de processos, mesmo em locais onde não houve a sua ocorrência;

- A falta de objetos facilmente identificáveis impossibilita um melhor ajuste das fotografias aéreas em relação a ortofoto. Neste trabalho, por exemplo, a localização de alguns depósitos foi feita com o auxílio do mapa de ângulo da encosta e a localização dos cursos d'água.

- O uso e ocupação do solo e a cobertura vegetal também limitam a interpretação destas feições, tanto nas encostas quanto nas baixadas, em que os depósitos são de difícil reconhecimento pelo método de fotointerpretação nas ortofotos. 


\subsection{Identificação dos parâmetros e índices morfométricos das bacias}

Para obter os parâmetros e índices morfométricos adotou-se o Modelo Digital de Terreno (MDT) disponibilizado pela Empresa Paulista de Planejamento Metropolitano (Emplasa), compatível com a escala de 1:25.000. O MDT foi construído por meio de ortofotos constituídas pela ortorretificação de fotografias aéreas com resolução aproximada de $45 \mathrm{~cm}$. A partir da composição destas imagens e da distribuição de pontos com coordenadas planialtimétricas e com espaçamento de, no mínimo, 15 metros, foi construído o MDT com resolução de $1 \mathrm{~m}^{2}$ (SCD-EMPLASA, 2016).

De posse do MDT e a priori da aquisição das variáveis morfométricas adotouse a rotina de remoção dos picos (peaks) e/ou o preenchimento das depressões (pits ou sinks) do modelo. Segundo Laing (2004) estas feições, pico e depressões, são decorrentes de pequenos erros nos valores de elevação ou erros causados pela resolução horizontal e vertical dos dados utilizados na criação do modelo. Assim, adotou-se a rotina de remoção com o intuito de minimizar os erros, eliminando, assim, tais feições (ZANDBERGEN, 2006; OLIVEIRA et al., 2007).

A partir da remoção dos picos e ou preenchimento das depressões do modelo utilizou-se o programa TerraHidro, para extrair a rede de drenagem, os limites da bacia e sub-bacias (Figura 22). O TerraHidro foi desenvolvido por Rosim et al. (2003) com o intuito de estudar os processos hidrológicos de forma integrada capturando, representando, armazenando, manipulando e processando no espaço e no tempo as informações do meio físico e socioambiental inerentes aos elementos espaciais em escala de bacia hidrográfica (ROSIM et al., 2008 e 2013). 


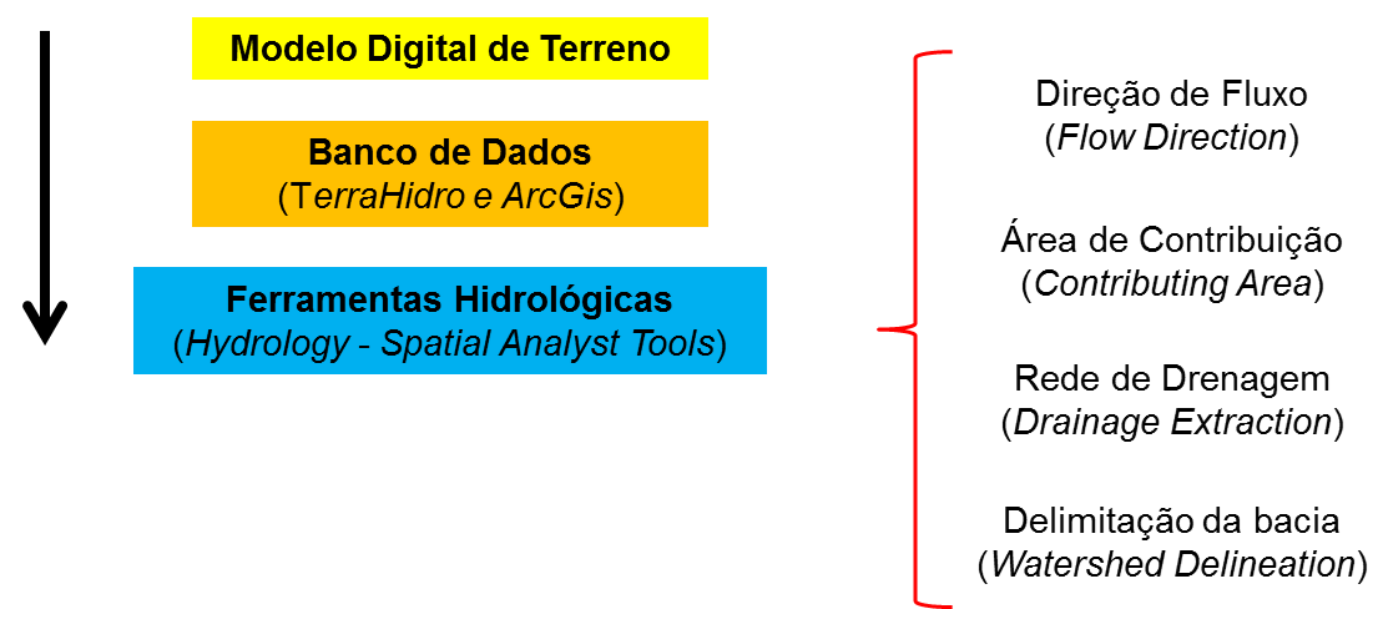

Figura 22: Fluxograma do procedimento de extração dos parâmetros no TerraHidro.

No ambiente TerraHidro, a rede de drenagem foi obtida utilizando-se do método D8, que considera apenas uma das oitos direções possíveis de escoamento para cada uma matriz (células) do MDT (O'CALLAGHAN e MARK, 1984; SILVA et al., 2010). Assim, a partir do conhecimento do gradiente de uma determinada célula, ou seja, a sua máxima inclinação descendente e a sua direção dada pela orientação do relevo, determina-se a direção do fluxo para uma única ou mais células (ROSIM et al., 2008) (Figura 23). Sendo assim, a extração da rede de drenagem foi determinada pelo valor de acúmulo do escoamento superficial resultante da análise de direção do fluxo e da área de contribuição (ROSIM et al., 2013) (Figura 24).
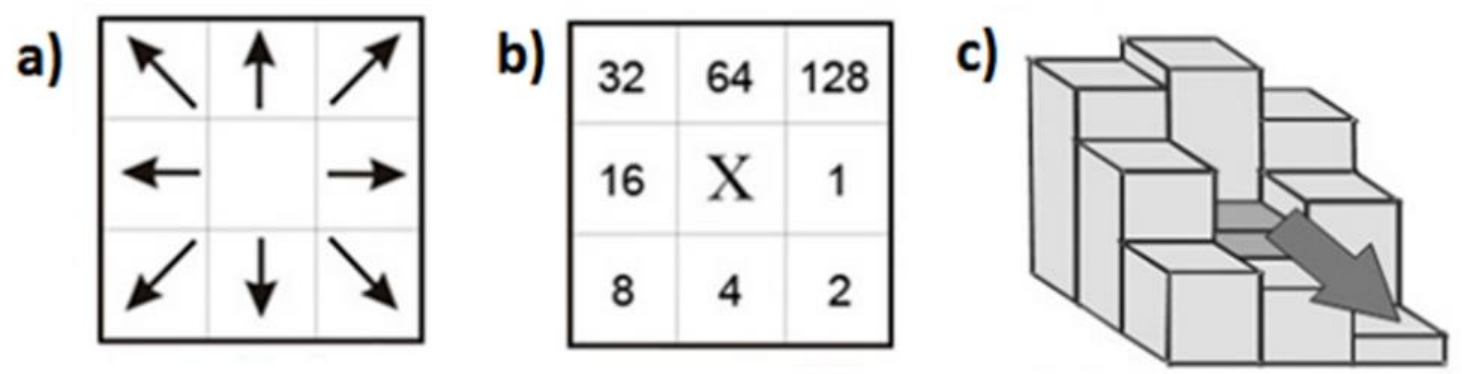

Figura 23: Esquema para determinação do fluxo contínuo, método D8: direções possíveis de um pixel (a); atribuição de códigos de direção para cada célula em volta da célula central (b; direção do escoamento para cada célula de menor cota. Fonte: Bosquilia et al. (2013). 

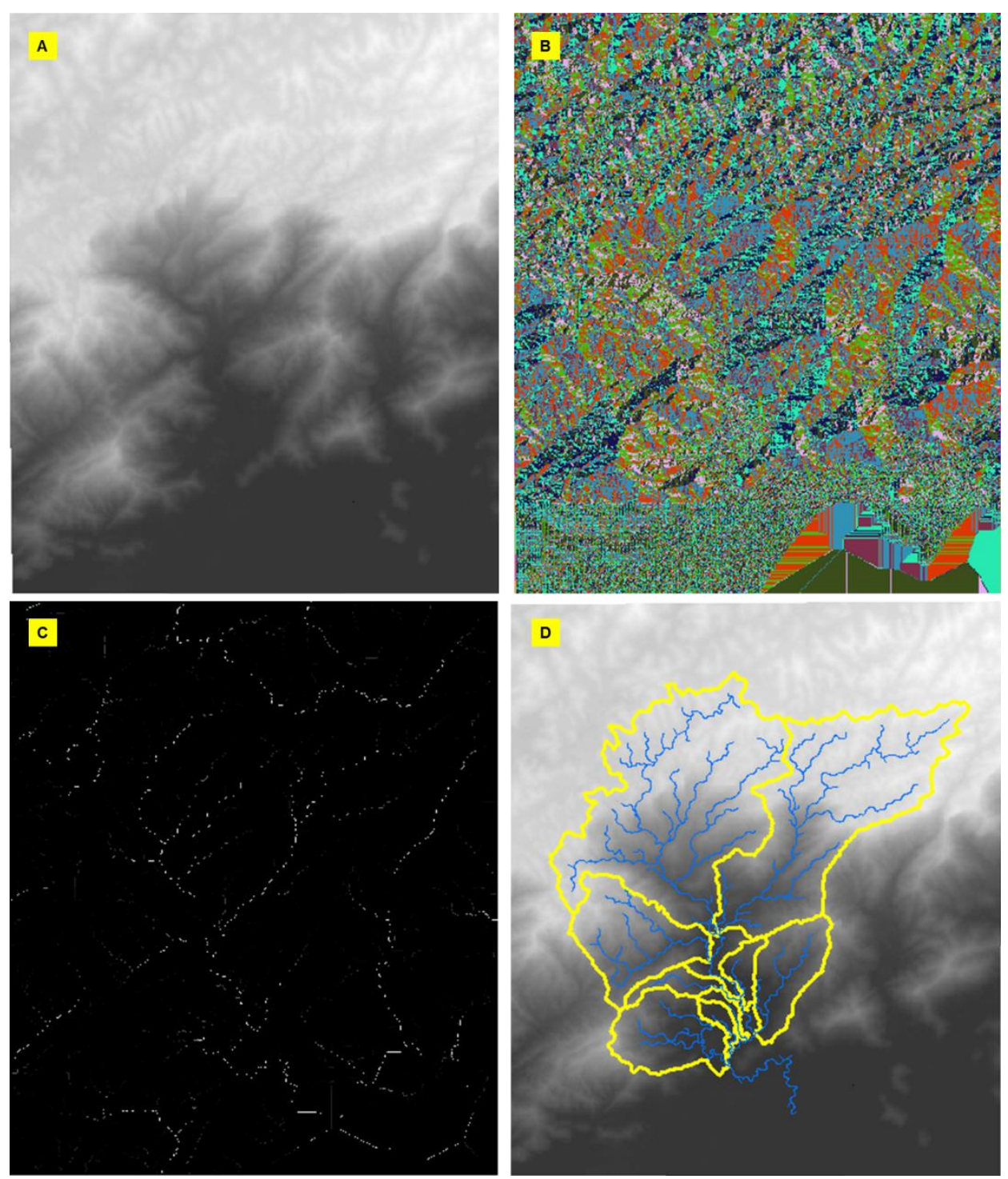

Figura 24: (a) Modelo Digital; (b) Direção de fluxo; (c) Área acumulada; e (d) rede de drenagem, bacia e sub-bacias.

Para determinar a representação da drenagem ou rede de drenagem aplicase um valor de entrada (Threshold) que, segundo Souza e Almeida (2014), serve como limiar para definir e identificar o número de células (grids) que representa a drenagem. Portanto, grids ou células em que o valor de acúmulo é superior a um determinado número, são assumidas como rede de drenagem (SALVADOR, 2007; ÁLVAREZ et al., 2012).

Para esta pesquisa foram realizados testes a partir da representação da hidrografia sobre o modelado do relevo e adotou-se a condição de valor 1000 , pois esta foi a mais representativa na caracterização da rede de drenagem. Tal 
procedimento se justifica devido à resolução do MDT, ou seja, quanto maior sua resolução espacial, maior será a quantidade de pixels na grade, logo será maior a quantidade de pixels a montante de um determinado ponto e, consequentemente maiores serão os valores de fluxo acumulado (SANTOS e FRANCISCO, 2011). Contudo, vale ressaltar que nesta pesquisa não houve verificação em campo e nem sobre a carta topográfica.

Posterior a extração da rede de drenagem executou-se a delimitação das bacias e sub-bacias a partir da identificação dos seus respectivos exutórios. Adotouse como critério de delimitação das sub-bacias, a confluência com o canal de maior ordem hierárquica, no caso, o canal principal. Esta decisão foi tomada, devido por meio da fotointerpretação e a identificação dos depósitos das corridas de detritos, para o evento 1967. Observou-se que estes processos ocorreram, em maior parte, ao longo dos canais de $3^{\circ}$ e $4^{\circ}$ ordens, próximos a confluência com o canal principal. Este procedimento resultou na identificação e na delimitação de sub-bacias de diferentes tamanhos de área para as bacias dos rios Santo Antônio, Guaxinduba e Mococa.

Salienta-se que durante as análises para a aquisição das informações das variáveis morfométricas, observou-se que o MDT da EMPLASA apresentou algumas inconsistências, dentre elas problemas relacionados à elevação. Por exemplo, em alguns trechos a altitude do mar foi identificada maior que a do continente. Além disso, observou-se que nas regiões planas das bacias analisadas, a rede de drenagem mostrou-se confusa e, que, segundo Santos e Francisco (2011), estes erros decorrem em função da menor amplitude altimétrica nestas áreas, não apresentando resultados satisfatórios, sendo necessária a correção manual com base na imagem e/ou curva de nível (PINHO et al., 2013). Estas incertezas apresentadas pelo modelo podem gerar erros nos parâmetros derivados (Wechsler, 2007), contudo, ressalta-se que os erros aqui mencionados não foram avaliados, visto que, os erros observados visualmente não foram significativos nas áreas de interesses desta pesquisa.

Por fim, a resultante desta rotina associada à acessibilidade dos Modelos Digitais de Terreno e ao seu rápido processamento em ambiente SIG, possibilitou 
estimar alguns comportamentos das corridas de detritos, tais como, a vazão de pico e o volume total de sedimentos, obtendo em associação com os modelos empíricos, o potencial de geração de corridas de detritos (volume total de sedimentos), para as bacias e sub-bacias da Serra do Mar Paulista, como observados por Augusto Filho (1993), IPT (2002) e Augusto Filho et al. (2005). 


\subsection{Hierarquização das bacias conforme os índices e a magnitude das corridas de detritos}

As informações necessárias para sistematização e hierarquização das bacias e sub-bacias na análise das corridas de detritos e o seu significado são apresentados no Quadro 1. A hierarquização das bacias quanto ao seu potencial de geração de corridas, em um primeiro momento, fundamentou-se nos aspectos mais significativos na deflagração destes processos encontrados na literatura, e pela identificação de feições nas imagens, entre eles, os escorregamentos e a presença ou ausência de depósitos.

Os parâmetros e os índices aqui empregados foram identificados como parâmetros mais significativos na deflagração das corridas de detritos nos trabalhos de Takahashi (1981), Jackson (1987), Slaymaker (1990), Jakob (1996), Wilford et al. (2004), Coe et al. (2004), Kanji et al. (2008) e Chen e Yu (2011).

A partir da escolha dos parâmetros e dos índices morfométricos, somada a ocorrência de movimentos de massa (escorregamentos e corridas de detritos), pôde se chegar a um resultado prévio da análise das sub-bacias. A determinação das bacias e das sub-bacias analisadas passou por um ranqueamento eliminando áreas que não apresentaram ocorrências, de escorregamentos e de corridas de detritos, para o ano de 1967, reduzindo o número de sub-bacias a serem analisadas (Figura 25). Portanto, o ranqueamento pode indicar baseado nos parâmetros e índices, quais sub-bacias apresentam maior magnitude na geração de corridas de detritos, permitindo assim a classificação destes processos. 
Quadro 1: Parâmetros e critérios adotados para determinar o potencial de geração de corridas nas bacias e sub-bacias selecionadas.

\begin{tabular}{|c|c|c|}
\hline \multicolumn{2}{|r|}{ Critérios } & Significado \\
\hline \multirow{7}{*}{ 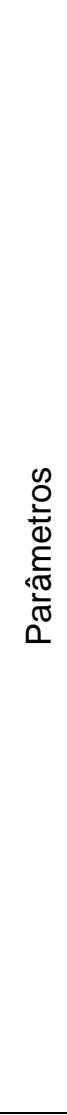 } & $\begin{array}{l}\text { Área da bacia ou sub- } \\
\text { bacia }\left(\mathrm{km}^{2}\right)\end{array}$ & $\begin{array}{c}\text { A área drenada da bacia tem alta correlação com o volume de } \\
\text { vazão e a produção de sedimentos, podendo apresentar-se como } \\
\text { um indicativo na ocorrência das corridas de detritos. }\end{array}$ \\
\hline & $\begin{array}{l}\text { Amplitude da bacia } \\
\qquad(\mathrm{m})\end{array}$ & $\begin{array}{l}\text { Responsável pela energia potencial necessária para o } \\
\text { escoamento do material mobilizado em um evento de corrida de } \\
\text { detritos. }\end{array}$ \\
\hline & Comp. do canal (km) & $\begin{array}{l}\text { Corresponde ao trecho do canal em que a corrida pode se } \\
\text { desenvolver. }\end{array}$ \\
\hline & $\begin{array}{l}\text { Área da bacia acima } \\
\text { de } 30^{\circ}(\%)\end{array}$ & Declividade crítica para a ocorrência de escorregamentos \\
\hline & $\begin{array}{l}\text { Declividade da } \\
\text { encosta }\left(^{\circ}\right)\end{array}$ & $\begin{array}{l}\text { A declividade apresenta-se como um parâmetro importante na } \\
\text { ocorrência dos escorregamentos, visto que contribui no } \\
\text { deslocamento dos sedimentos. A avaliação deste parâmetro } \\
\text { fundamenta-se na proposta de Gao (1993) por meio da } \\
\text { Concentração de Cicatrizes (CC) que é a razão do número de } \\
\text { células, de cada classe, que contém a cicatriz e o total de células } \\
\text { da bacia e o Potencial de Escorregamento (PE), que é a razão } \\
\text { do número de células, de cada classe, afetadas pelas cicatrizes e } \\
\text { o total de células dessa mesma classe. }\end{array}$ \\
\hline & $\begin{array}{c}\mathrm{N}^{\circ} \text { de } \\
\text { escorregamentos }\end{array}$ & $\begin{array}{l}\text { Sua ocorrência pode ser um indicador da ocorrência ou não de } \\
\text { corridas de detritos nas sub-bacias analisadas. }\end{array}$ \\
\hline & $\begin{array}{l}\text { Presença ou ausência } \\
\text { de depósitos }\end{array}$ & $\begin{array}{l}\text { A presença destes materiais, ao longo da rede de drenagem, pode } \\
\text { contribuir com o aumento no volume de sedimentos em eventos } \\
\text { futuros. }\end{array}$ \\
\hline \multirow{4}{*}{ 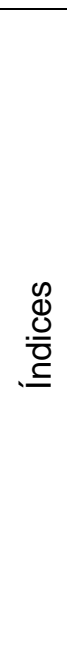 } & Índice de circularidade & $\begin{array}{l}\text { Este índice é responsável pelo comportamento do tempo de } \\
\text { escoamento dentro da bacia. Quanto mais próximo do valor da } \\
\text { unidade maior será a potencialidade de geração de cheias e, } \\
\text { consequentemente, poderá contribuir para a geração de corridas } \\
\text { de detritos. }\end{array}$ \\
\hline & $\begin{array}{l}\text { Densidade de } \\
\text { drenagem }\end{array}$ & $\begin{array}{l}\text { Pode indicar o tempo de deslocamento da água, a vazão e o } \\
\text { potencial de inundação. Em nível de sub-bacias isto pode sugerir, } \\
\text { que áreas com menor densidade de drenagem podem apresentar } \\
\text { uma baixa contribuição no deslocamento das corridas de detritos. }\end{array}$ \\
\hline & $\begin{array}{l}\text { Declividade média do } \\
\text { canal principal }\end{array}$ & $\begin{array}{l}\text { Pode auxiliar na identificação de possíveis zonas de } \\
\text { amortecimento dos materiais provenientes das encostas ou do } \\
\text { próprio canal. }\end{array}$ \\
\hline & $\begin{array}{c}\text { Densidade de } \\
\text { escorregamentos }\end{array}$ & $\begin{array}{l}\text { Número de escorregamento por unidade de área. Pode haver uma } \\
\text { relação com a ocorrência de corridas de detritos. }\end{array}$ \\
\hline
\end{tabular}



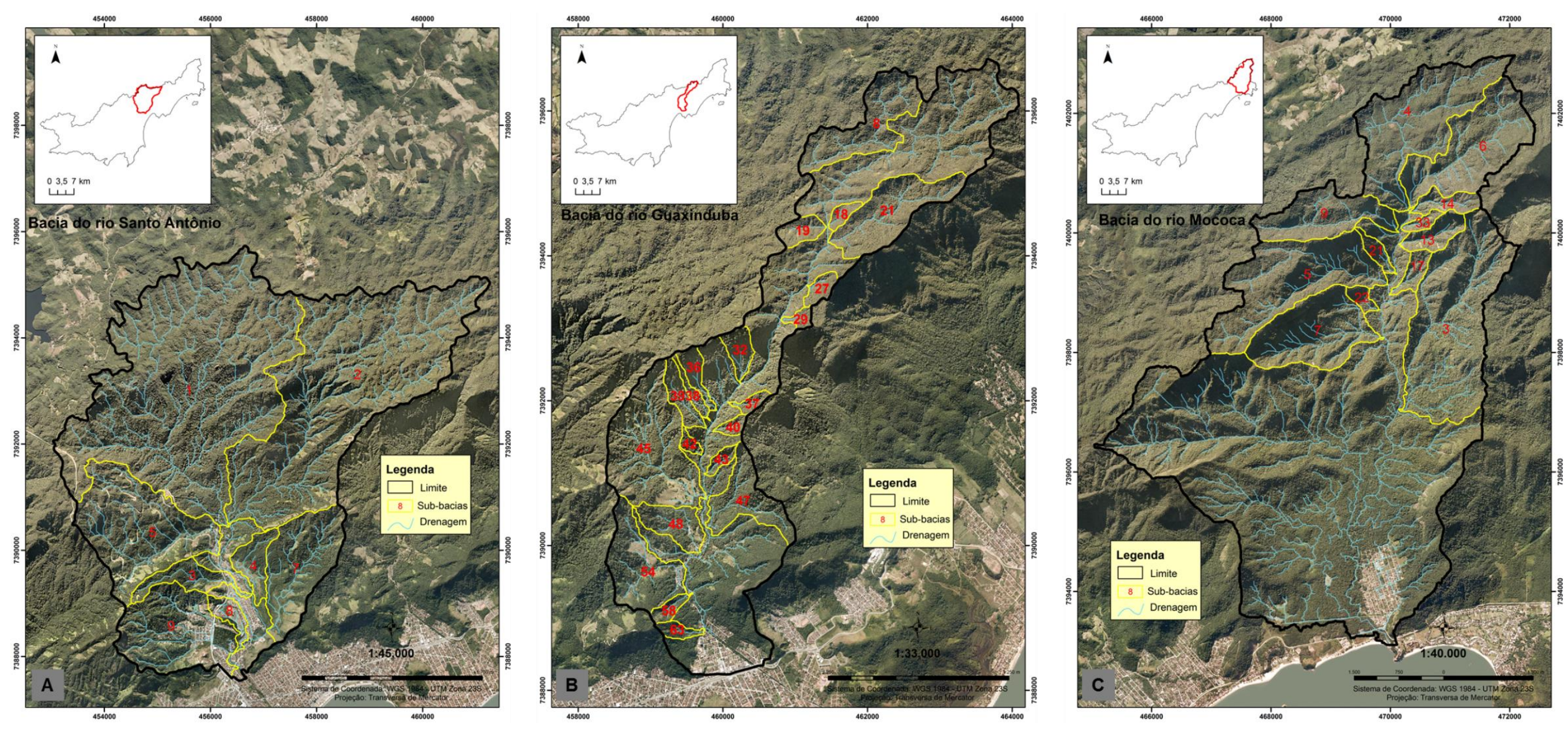

Figura 25: Mapa das bacias e suas respectivas sub-bacias selecionadas para as análises qualitativa e quantitativa: Santo Antônio (a), Guaxinduba (b) e Mococa (c). Os critérios adotados para a seleção destas sub-bacias foi a ocorrência de escorregamentos e/ou corridas de detritos. 


\subsection{Análise quantitativa do potencial de geração das corridas de detritos}

A avaliação do potencial de geração de corridas de detritos baseou-se nos critérios de ocorrência de escorregamentos e de deposição ou zona de arraste para o evento de 1967, totalizando, assim, 40 sub-bacias selecionadas para análise da vazão de pico e do volume total de sedimentos.

A obtenção dos valores de magnitude ou volume total de sedimentos ocorreu por meio do emprego do modelo empírico proposto por Takahashi (1991) (Eq. 8). A estimativa da vazão de pico das corridas de detritos foi baseada nos modelos empíricos de Araya Moya (1994) e Massad et al. (1997), Equações 3 e 2, respectivamente.

Para o caso da vazão de pico é necessário o conhecimento da concentração de sólidos $\left(c^{*}\right)$, que corresponde a fração sedimentar da corrida de detrito. Por meio de observações dos depósitos das corridas de detritos na Serra do Mar, em Cubatão, Massad et al. (1997), verificaram que a concentração de sólidos destes processos corresponde a 50\%. Neste sentido, devido à similaridade fisiográfica das bacias na Serra do Mar, acredita-se que o comportamento destes processos nas áreas em análise seja igual permitindo, assim, a adoção deste mesmo valor.

Com o objetivo de compreender o comportamento do potencial de geração de corridas e a vazão de pico de cada sub-bacia, adotaram-se dois valores de precipitação para compor cada cenário. Tais valores fundamentaram-se na análise de tempo de retorno (TR) estabelecido por IPT (2002) com base em 8 eventos de corridas de detritos na Serra do Mar, no trecho que corresponde a Baixada Santista. Neste sentido, foram propostos dois cenários de precipitação que correspondem a tempos de retorno de uma década $(60 \mathrm{~mm} / \mathrm{h})$ e de cem anos $(100 \mathrm{~mm} / \mathrm{h})$.

O Quadro 2 reúne as informações e os parâmetros necessários para a geração do modelo proposto. 
Quadro 2: Informações para obtenção das estimativas de vazão de pico e magnitude.

\begin{tabular}{|c|c|c|}
\hline Parâmetros ou Índices & Dados obtidos & Unidade \\
\hline Concentração de sólidos* & 50 & \multirow{2}{*}{$\mathrm{mm} / \mathrm{h}$} \\
\hline \multirow{2}{*}{ Precipitação (Cenário)** } & 60 & $\mathrm{Km}^{2}$ \\
\cline { 2 - 3 } & 100 & $\mathrm{~m}^{*}$ \\
\hline Área & Em ambiente SIG & $\mathrm{km}$ \\
\hline Amplitude & Em ambiente SIG & $\mathrm{km}$ \\
\hline Comprimento do rio & Em ambiente SIG & \\
\hline
\end{tabular}

*Massad et al. (1997); **IPT (2002).

Nesta pesquisa propõe-se a hierarquização do potencial de geração das subbacias em função da magnitude (volume de sedimentos), a partir de um refinamento da classificação proposta por Jakob (2005). Diferente de Fell (1994) que propôs uma classificação para movimentos de massa baseado somente no volume, Jakob (2005) utilizou-se de outros parâmetros para classificar os eventos de corridas de detritos.

A classificação de Jakob (2005) divide-se em 10 classes e baseia-se no volume, na vazão de pico e a sua área de inundação e, consequentemente, os possíveis danos esperados a partir de certo evento e de determinada magnitude (Tabela 1, pág. 25). Somente as 5 primeiras classes trazidas pelo autor foram consideradas, pois representam os casos de corridas de detritos que não estão associadas a vulcanismos.

Para o refinamento e representação das classes de Jakob (2005) e que correspondem as classes de potencial de geração de corridas, nesta pesquisa utilizou-se o método de classificação conhecido como quebras naturais (natural breaks), o qual se baseia em agrupamentos naturais intrínsecos aos dados. Sendo assim, foram gerados mapas quantitativos, representando a hierarquização do potencial de geração de corridas de detritos das sub-bacias analisadas frente a cada cenário proposto, com o auxílio do sistema ArcGIS.

Além disso, para fins de ilustração dos danos potenciais, os eventos ocorridos no Brasil registrados por Kanji et al. (2003) foram classificados com base em Jakob 
(2005), tendo como critério de seleção destes eventos aqueles que apresentarem registros da sua magnitude (volume de sedimentos). 
Tabela 2: Classificação das corridas de detritos.

\begin{tabular}{|c|c|c|c|c|c|c|c|}
\hline Classe & $V\left(\mathrm{~m}^{3}\right)$ & $Q_{b}\left(\mathrm{~m}^{3} / \mathrm{s}\right)$ & $Q_{v}\left(\mathrm{~m}^{3} / \mathrm{s}\right)$ & $B_{b}\left(\mathrm{~m}^{2}\right)$ & $B_{v}\left(\mathrm{~m}^{2}\right)$ & Características & Dano potencial \\
\hline 1 & $<10^{2}$ & $<5$ & $<1$ & $<4 \times 10^{2}$ & $<4 \times 10^{3}$ & $\begin{array}{l}\text { Ocorrem em pequenos canais, mobilizando pouco } \\
\text { material; podem deflagrar dentro do canal, por } \\
\text { escorregamento ou queda de bloco; escoamento } \\
\text { rápido em depósitos altamente permeável e com } \\
\text { baixa declividade. }\end{array}$ & $\begin{array}{l}\text { Muito localizado, podendo ocasionar a morte de } \\
\text { agentes ambientais nos pequenos talvegues; } \\
\text { danos em pequenas construções. }\end{array}$ \\
\hline 2 & $10^{2}-10^{3}$ & $5-30$ & $1-3$ & $4 \times 10^{2}-2 \times 10^{3}$ & $4 \times 10^{3}-2 \times 10^{4}$ & $\begin{array}{l}\text { Ocorrem em pequenos córregos; apresentam uma } \\
\text { menor frequência destes processos devido à falta } \\
\text { de material predisponente para cada evento; são } \\
\text { condicionados por eventos hidroclimáticos. }\end{array}$ & $\begin{array}{l}\text { Soterrar carros, destruição de pequenas } \\
\text { construções de madeira, ceifar árvores, bueiros e } \\
\text { descarrilamento de trens. }\end{array}$ \\
\hline 3 & $10^{3}-10^{4}$ & $30-200$ & $3-30$ & $2 \times 10^{3}-9 \times 10^{3}$ & $2 \times 10^{4}-9 \times 10^{4}$ & $\begin{array}{l}\text { Ocorrem em pequenas bacias hidrográficas }(<5 \\
\left.\mathrm{km}^{2}\right) \text {; período de retorno podendo abranger } \\
\text { décadas; evidências de sua ocorrência apagadas } \\
\text { com o passar do tempo (erosão ou crescimento da } \\
\text { vegetação). }\end{array}$ & $\begin{array}{l}\text { Pode destruir construções de maiores } \\
\text { dimensões, danos nas pilastras de pontes de } \\
\text { concreto, bloquear ou danificar rodovias e dutos. }\end{array}$ \\
\hline 4 & $10^{4}-10^{5}$ & $200-1500$ & $30-300$ & $9 \times 10^{3}-4 \times 10^{4}$ & $9 \times 10^{4}-4 \times 10^{5}$ & $\begin{array}{l}\text { Apresenta a mesma característica da classe } 3 \text {, } \\
\text { porém com período de retorno de } 100 \text { anos para } \\
\text { bacias hidrográficas com áreas }>5 \mathrm{~km}^{2} \text {. }\end{array}$ & $\begin{array}{l}\text { Pode destruir vilas, seções de corredores de } \\
\text { infraestruturas, pontes, podem bloquear } \\
\text { córregos. }\end{array}$ \\
\hline 5 & $10^{5}-10^{6}$ & $1500-12000$ & $300-3 \times 10^{4}$ & $4 \times 10^{4}-2 \times 10^{5}$ & $4 \times 10^{5}-2 \times 10^{6}$ & $\begin{array}{l}\text { Ocorrem em locais com abundância de áreas } \\
\text { fontes; sua ocorrência é rara; e evidências físicas } \\
\text { de eventos passados podem apenas ser } \\
\text { interpretadas por análises sedimentológicas ou } \\
\text { exposições naturais na área da trajetória. }\end{array}$ & $\begin{array}{l}\text { Pode destruir parte da cidade, destruir florestas } \\
\text { de } 2 \mathrm{~km}^{2} \text { de área, obstrução de rios e riachos }\end{array}$ \\
\hline 6 & $10^{5}-10^{6}$ & $\mathrm{~N} / \mathrm{A}$ & $3 \times 10^{3}-3 \times 10^{4}$ & $>2 \times 10^{5}$ & $2 \times 10^{6}-3 \times 10^{7}$ & & $\begin{array}{l}\text { Pode destruir cidades, obstruir vales ou construir } \\
\text { leques de várias dezenas de tamanho }\left(\mathrm{km}^{2}\right) \text {, } \\
\text { represar rios }\end{array}$ \\
\hline 7 & $10^{6}-10^{7}$ & $\mathrm{~N} / \mathrm{A}$ & $3 \times 10^{4}-3 \times 10^{5}$ & $N / A$ & $3 \times 10^{7}-3 \times 10^{8}$ & $\begin{array}{l}\text { Sem um sistema de alerta, as corridas de detritos, } \\
\text { nestes intervalos, podem causar milhares a } \\
\text { centenas de milhares de fatalidades e destruição, }\end{array}$ & $\begin{array}{l}\text { Pode destruir parte da cidade, obstruir vales ou } \\
\text { construir leques aluviais de várias dezenas de } \\
\text { tamanho }\left(\mathrm{km}^{2}\right) \text {, pode represar grandes rios }\end{array}$ \\
\hline 8 & $10^{7}-10^{8}$ & $\mathrm{~N} / \mathrm{A}$ & $3 \times 10^{5}-3 \times 10^{6}$ & $\mathrm{~N} / \mathrm{A}$ & $3 \times 10^{8}-3 \times 10^{9}$ & $\begin{array}{l}\text { em escala regional, com consequências } \\
\text { socioeconômicas de longo prazo. }\end{array}$ & $\begin{array}{l}\text { Pode destruir cidades, inundar grandes vales } \\
\left.\text { (até } 100 \mathrm{~km}^{3}\right) \text {, represar grandes rios }\end{array}$ \\
\hline $\begin{array}{c}9 \\
10\end{array}$ & $10^{8}-10^{9}$ & N/A & $3 \times 10^{6}-3 \times 10^{7}$ & $\mathrm{~N} / \mathrm{A}$ & $3 \times 10^{9}-3 \times 10^{10}$ & & Vasta e completa destruição sobre uma área de \\
\hline 10 & $>10^{9}$ & N/A & $3 \times 10^{7}-3 \times 10^{8}$ & $N / A$ & $>3 \times 10^{10}$ & & centenas de $\mathrm{km}^{2}$ \\
\hline
\end{tabular}

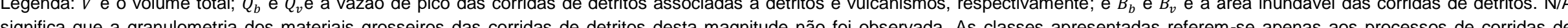
apenas aos processos de corridas de detritos, portanto, as demais classes (6 a 10) não serão abordadas nesta tabela. Fonte: Adaptado e modificado de Jakob (2005). 


\section{RESULTADOS E DISCUSSÕES}

Foram identificadas 232 cicatrizes de escorregamentos, com áreas variando entre 46 e $94.627 \mathrm{~m}^{2}$, e volume médio de sedimentos entre 2.766 e $6.348 \mathrm{~m}^{3}$ para as três bacias. A densidade de escorregamento foi de 2,8 (Santo Antônio), 2,7 (Guaxinduba) e 1,6 (Mococa) (Item 5.1).

As zonas de deposição e de arraste foram observadas nas três bacias, porém com comportamentos distintos. Evidenciou-se que tais processos foram identificados em declividades inferiores a $20^{\circ}$ e de forma distinta entre as bacias (Item 5.2).

De forma qualitativa foram expressas as análises dos parâmetros e índices morfométricos nos itens 5.3 e 5.4. No item 5.3, os parâmetros e índices morfométricos empregados indicaram comportamento distintos entre as bacias, com comportamento diferenciado na ocorrência dos processos (escorregamentos e corridas de detritos). As similaridades entre alguns parâmetros foram de acordo com a ocorrência destes processos nestas bacias, indicando a bacia do Guaxinduba mais suscetível à ocorrência das corridas de detritos.

O item 5.4 compara 20 sub-bacias dos rios Santo Antônio e Mococa, ambas com $37 \mathrm{Km}^{2}$, porém com comportamento distinto na deflagração das corridas de detritos. Na análise proposta observou-se que a avaliação do potencial de corridas foi mais plausível em escala de sub-bacias.

O item 5.5 apresenta os resultados dos modelos empíricos adotados indicando o potencial das corridas de detritos em relação ao volume de sedimentos gerados por cada sub-bacia. Já o item 5.6 aborda a classificação dos eventos registrados no Brasil e, também nas sub-bacias analisadas, indicando características e potencial de dano esperado. 


\subsection{Análise das áreas fonte (escorregamentos) para o evento de 1967}

As bacias dos rios Santo Antônio, Guaxinduba e Mococa concentraram 106, 51 e 75 cicatrizes de escorregamentos, respectivamente (Figuras 26 e 27). As estimativas de sedimentos para as bacias analisadas variaram entre 22,90 a 47.313 $\mathrm{m}^{3}$, com média de $5.961 \mathrm{~m}^{3}$ (Santo Antônio), 625 a $47.032 \mathrm{~m}^{3}$, com média de 6.348 $\mathrm{m}^{3}$ (Guaxinduba), e 192 a $34.605 \mathrm{~m}^{3}$ e média de $2.766 \mathrm{~m}^{3}$ (Mococa), conforme o Apêndice I.

Observou-se que à medida que há o aumento no valor de área da cicatriz do escorregamento há também o aumento no valor de sedimentos, como verificado por Reid e Page (2002) e Guthrie e Evans (2004a). Guzzetti et al. (2009) afirmam que o comportamento de dependência desta relação independe do ambiente climático ou fisiogeográfico e apenas dos fatores geométricos de cada cicatriz. Para estes autores, esta relação de dependência não leva em consideração as propriedades e mecanismos que deflagram estes processos. 


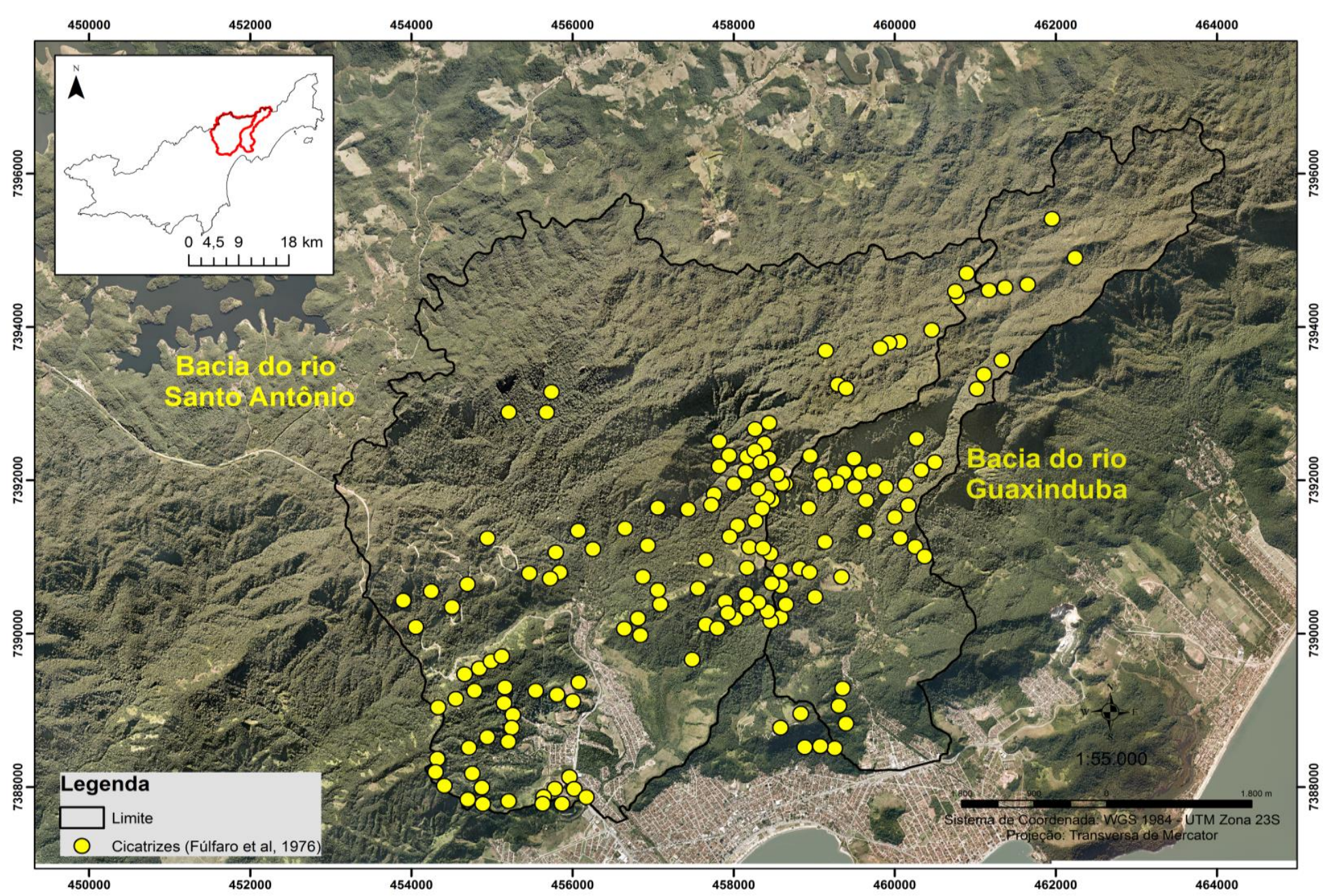

Figura 26: Mapa de cicatrizes das bacias dos rios Santo Antônio e Guaxinduba. 


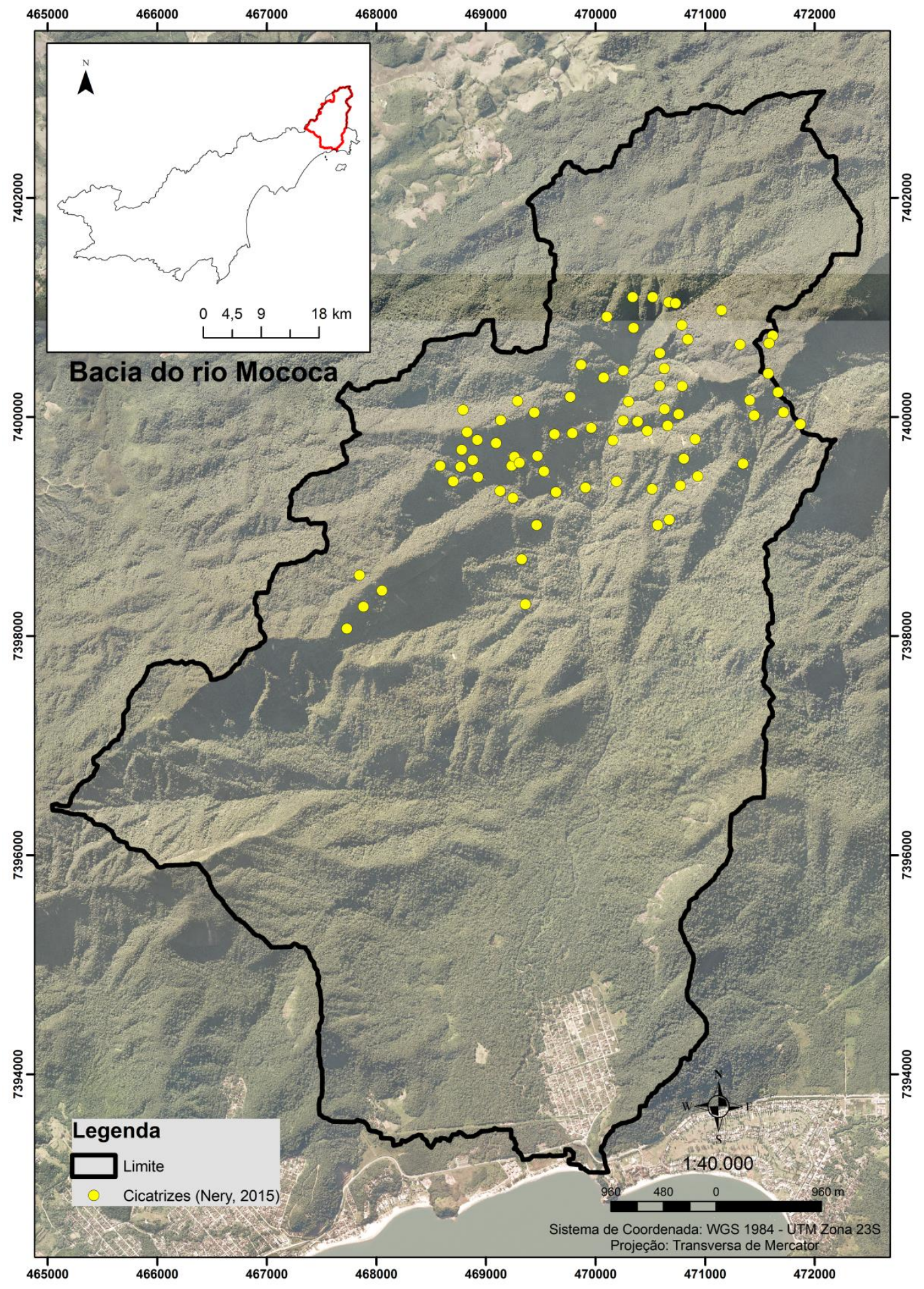

Figura 27: Mapa de cicatriz da bacia do rio Mococa. 
Em relação aos dados obtidos nesta pesquisa verificou-se na literatura, que os valores de sedimentos provenientes das cicatrizes variaram, mesmo para áreas de tamanhos aproximados. $\mathrm{O}$ emprego de métodos observados e estimados, como verificado em alguns casos, ora superestimou ora subestimou o valor de sedimentos para cada cicatriz. Os valores de espessura verificados na literatura, em sua maior parte, variaram entre 0,5 até $5 \mathrm{~m}$.

Rood (1984) afirma que em determinados casos o volume de sedimentos, para um número razoável de processos, e a extensão da ruptura obtida por fotografias aéreas e/ou medidas em campo podem ser equivalentes. A resultante entre o volume estimado e o observado para todas as rupturas pode variar, para mais ou para menos, variando em torno de $400 \mathrm{~m}^{3}$ (ROOD, 1984). Observações a respeito dessa relação foram feitas por Martin et al. (2002) que avaliaram em seu trabalho 40 de 615 escorregamentos em British Columbia e verificaram, em média, que os volumes determinados por meio de fotografias áreas foram $15 \mathrm{~m}^{3}$ inferior em relação ao volume determinado em campo. Estes resultados justificaram o emprego deste método e o valor de espessura, aqui adotado, indicando que em áreas remotas, tal método pode auxiliar na obtenção do valor estimado pelo material mobilizado.

Comparando com os resultados obtidos por Martin et al. (2002), verificou-se que os valores foram muito semelhantes. Os autores avaliaram que os volumes de sedimentos para os movimentos de massa variaram entre 217 e $16.100 \mathrm{~m}^{3}$, e os valores encontrados nesta pesquisa para 220 escorregamentos estão entre $236 \mathrm{e}$ $15.051 \mathrm{~m}^{3}$ para processos com áreas entre 472,5 e $30.102 \mathrm{~m}^{2}$. Esta aproximação de valores pode ser explicada pela espessura de ruptura adotada em ambas as pesquisas $(0,5 \mathrm{~m})$. Além disso, isso pode indicar que para o evento de 1967 , os escorregamentos com áreas de $30.000 \mathrm{~m}^{2}$ podem ter contribuído de forma mais significativa para o volume de sedimentos das corridas de detritos, visto que, feições com dimensões superiores ocorreram de forma expressiva nas bacias.

Guzzetti et al. (2009) avaliaram a relação da área dos escorregamentos em função do volume de sedimentos na Itália e verificaram que para áreas mínimas e máximas, 20 e $70.000 \mathrm{~m}^{2}$, os valores de volumes de sedimentos variaram entre 0,34 
e $29.000 .000 \mathrm{~m}^{3}$. Para áreas mínimas e máximas, 46 e $94.627 \mathrm{~m}^{2}$, de todos os escorregamentos observados, os volumes de sedimentos ficaram entre 23 e 47.313 $\mathrm{m}^{3}$.

Como observado por Guzzetti et al. (2009), há uma relação direta entre a área e o volume e, quanto maior for a área, maior será o volume de sedimentos. Entretanto, esta relação também é dependente da espessura adotada em cada feição do processo (GUZZETTI et al., 2009). Ou seja, cicatrizes de mesma área, porém, com variação na espessura, podem gerar volumes de sedimentos distintos.

A respeito desta condição, Hancox et al. (2003), verificaram que cicatrizes de áreas similares para um determinado tipo de processo, por exemplo, os escorregamentos rasos, apresentaram volumes de sedimentos distintos. De fato, quando comparado com os resultados de Guthrie e Evans (2004b) para uma área de $1.124 \mathrm{~m}^{2}$ o volume encontrado por estes autores foi de $280 \mathrm{~m}^{3}$, valor este, duas vezes abaixo daqueles encontrados para cicatrizes de áreas similares na bacia do Santo Antônio (1.057 e $1.127 \mathrm{~m}^{2}$, com volume de 529 e $563 \mathrm{~m}^{3}$, respectivamente). Isso demonstra que a espessura de ruptura encontrada por estes autores pode ter sido menor do que a adotada nesta pesquisa.

A quantidade de material disponibilizado por cada escorregamento é de difícil mensuração, como foi observado por Fúlfaro et al. (1976) para o evento de 1967 em Caraguatatuba. Tais autores verificaram que muitos destes sedimentos foram transportados para áreas mais planas ou depositados na própria encosta. Fato este também observado por Reid e Page (2002) na Nova Zelândia. Estes autores observaram tais fenômenos por meio de fotografias aéreas e em campo, e verificaram que os escorregamentos contribuíram com $25 \%$ do volume de sedimentos que alcançaram o canal. Aqui, devido à ausência de mensuração destes processos em campo, assume-se que cada cicatriz tenha contribuído entre 0,041 e $58 \%$ para as corridas de detrito deflagradas em 1967 (Figura 28). 


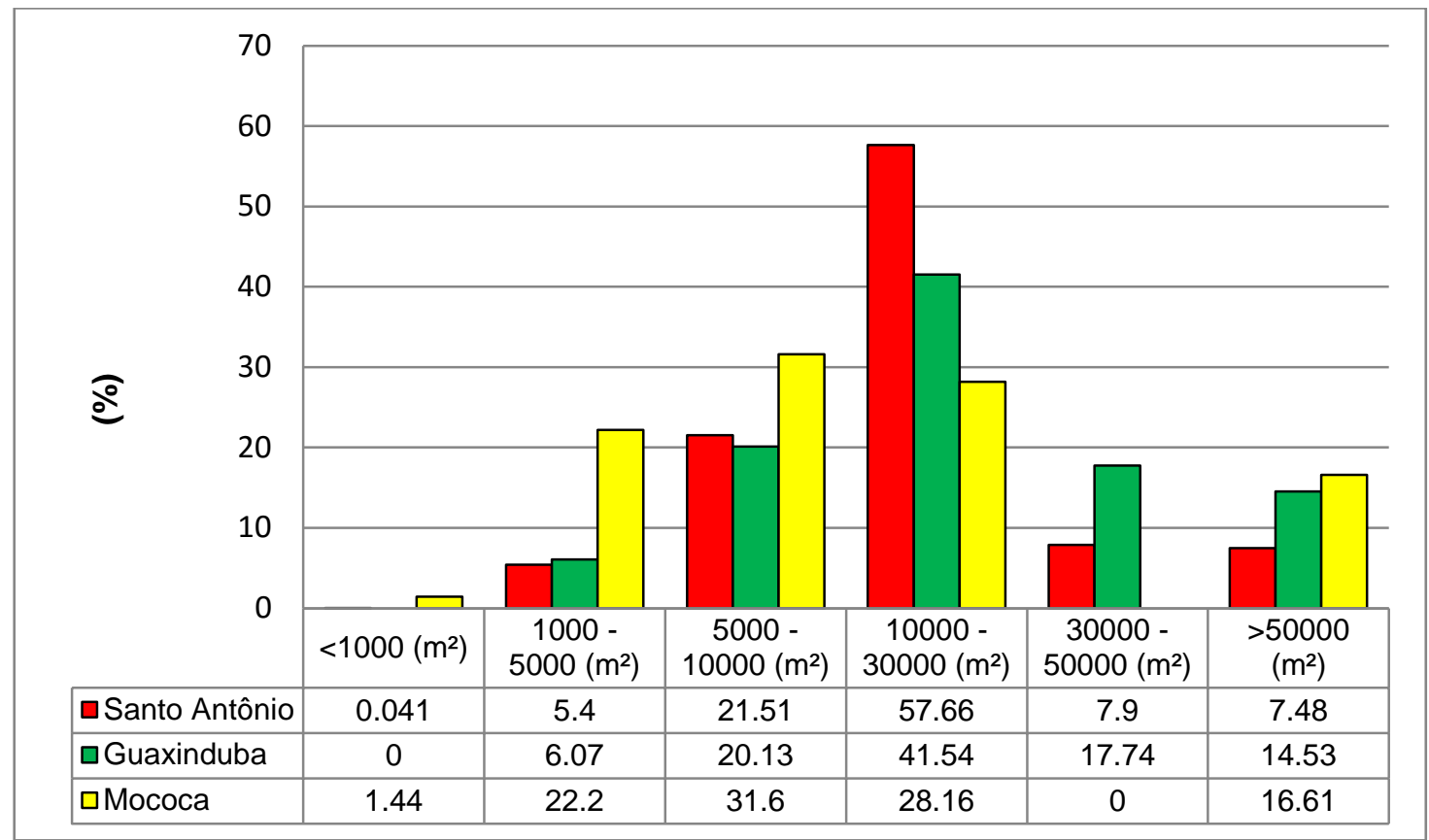

Figura 28: Gráfico apresentando a contribuição de sedimentos por área da cicatriz. Observa-se a predominância de áreas de cicatrizes entre 5000 e $30000 \mathrm{~m}^{2}$, representando valores acima de $60 \%$ : Mococa (60\%), Guaxinduba (62\%) e Santo Antônio (79\%). Cicatrizes com áreas inferiores a 1000 contribuem com menos de $1,5 \%$. 


\subsection{Reconhecimento das áreas de deposição das corridas de detritos}

As áreas delimitadas como zonas de deposição e de arraste apresentaram comportamentos distintos, ocorrendo em diferentes pontos das bacias, porém identificadas nas mesmas declividades (inferiores a $20^{\circ}$ ).

As áreas dos depósitos variaram entre 30.017 a $514.784 \mathrm{~m}^{2}$ (rio Santo Antônio), entre 3.710 a $121.418 \mathrm{~m}^{2}$ (rio Guaxinduba) e entre 2.881 a $43.027 \mathrm{~m}^{2}$ (rio Mococa). As maiores áreas de deposição foram identificadas em locais mais planos, principalmente para as bacias dos rios Santo Antônio e Guaxinduba, onde acreditase que o deslocamento do fluxo destes sedimentos tenha perdido velocidade e se espraiado e, tendo sido depositados assim sobre antigos depósitos colúvio-aluviais.

Analisando os depósitos mapeados por Cruz (1974), que totalizaram 2.461.250 $\mathrm{m}^{2}$ de área, verificou-se que estes ocuparam a maior parte da planície da bacia do rio Santo Antônio (Figura 29). Observações realizadas dias após o evento, pela autora, mostraram a deposição de grandes blocos misturados a sedimentos menos grosseiros formando depósitos entre $0,80 \mathrm{~m}$ e $5 \mathrm{~m}$ de altura nas áreas planas (CRUZ, 1974). Segundo a autora, a magnitude do evento nesta bacia foi tão alta que ela identificou no afluente da margem esquerda do rio Santo Antônio blocos com até $5 \mathrm{~m}$ de diâmetro que se deslocaram por quase $1 \mathrm{~km}$, exumando antigos depósitos colúvio-aluvionares (Figura 30). 


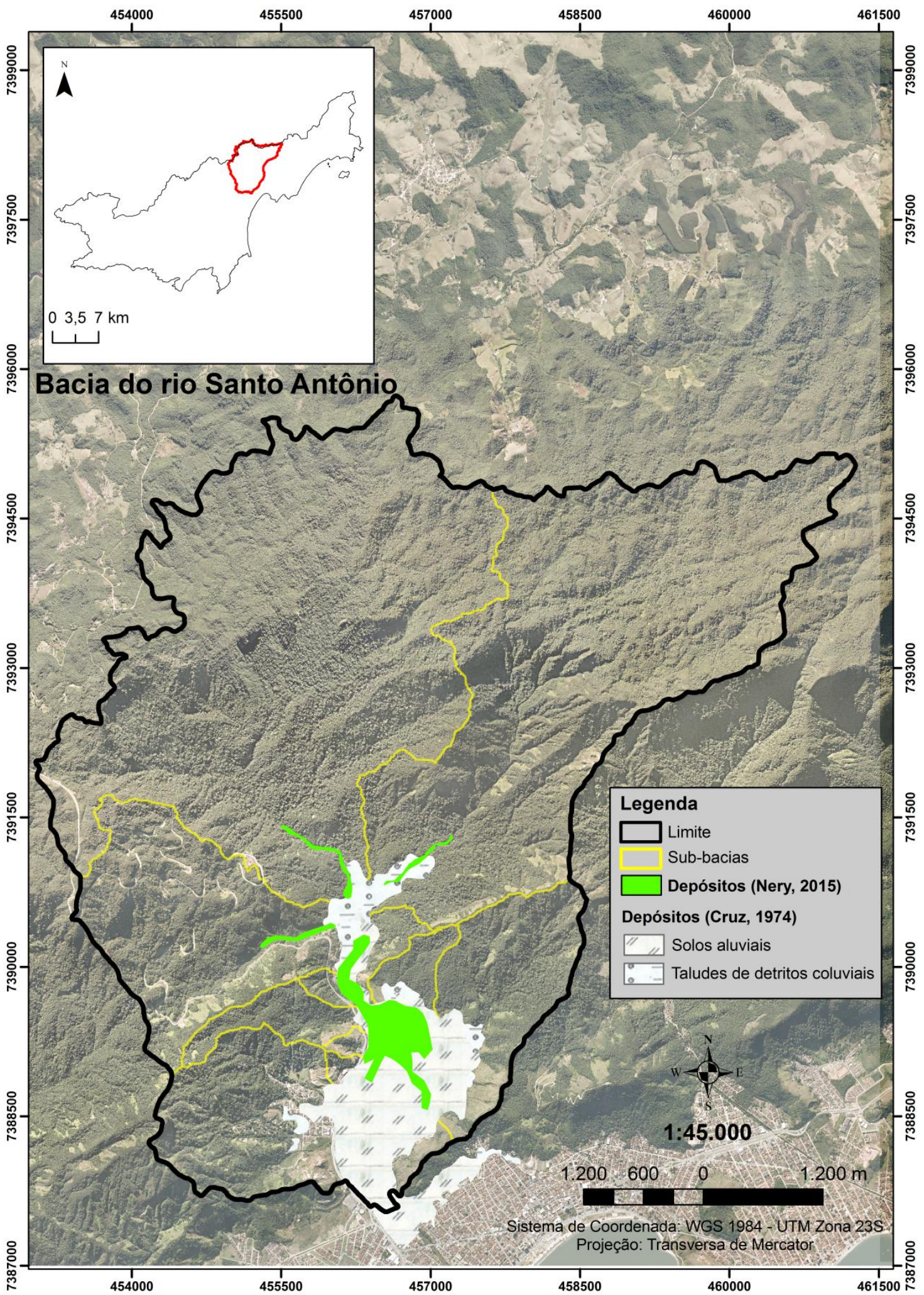

Figura 29: Mapa dos depósitos da bacia do rio Santo Antônio. 


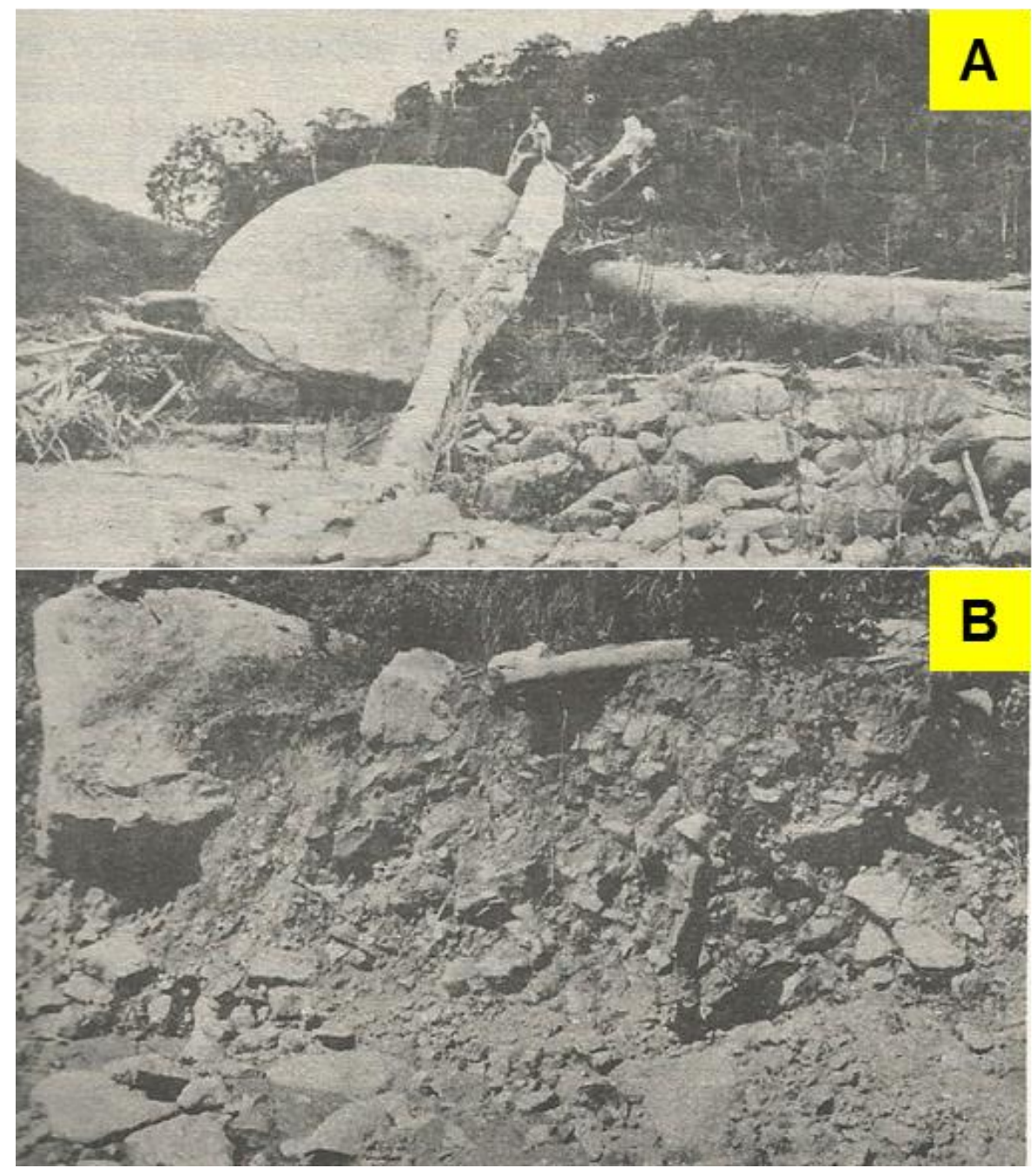

Figura 30: Blocos de tamanhos variados em um afluente do rio Santo Antônio com diâmetros de até de $5 \mathrm{~m}$ (a). A passagem da corrida exumou os depósitos mais antigos compostos, na maior parte, por blocos de diâmetros menores (b). Fonte: Olga Cruz.

A bacia do Santo Antônio, diferente das demais, apresenta dois espigões ou alvéolos, que delimitam o contato entre a região de escarpa, a área plana da bacia e a faixa litorânea (CRUZ, 1974). No primeiro, sentido a jusante da bacia, Cruz (1974) observou a presença de taludes de detritos coluviais, composto por blocos maiores, entre a encosta e o canal de drenagem. Segundo a autora, o acúmulo de blocos desta ordem de grandeza foi devido a um pequeno estrangulamento da bacia que, associado à diminuição do ângulo das encostas $\left(<20^{\circ}\right)$ e a uma menor vazão do rio, permitiu a deposição e acumulação dos sedimentos mais grosseiros neste setor da bacia. 
No entanto, a autora ressalta que a presença destes sedimentos grosseiros também, pode estar condicionada à litologia da bacia e às suas respectivas fraturas que, junto ao intemperismo químico, induziu a ocorrência de blocos individualizados (CRUZ, 1974), e somado aos diferentes níveis de ângulo da encosta pode ter contribuído, por meio do deslocamento gravitacional, para a presença destes sedimentos próximos a este estrangulamento do canal (Figura 31). Esta situação pode induzir a uma interpretação de que nem todos os blocos grosseiros ali presentes foram transportados pelas corridas, mas sim pelas sucessivas fases de ocorrência de diferentes tipos de processos, principalmente os escorregamentos.

Entre as áreas de escarpa e a faixa litorânea, onde se insere o bairro Santo Antônio, foram identificados os depósitos aluviais (CRUZ, 1974), recobrindo toda a área plana do rio, antes de desembocar no mar. Toda carga de sedimentos mais finos foi observada neste trecho. Além destes materiais, foram depositados troncos e galhos de árvores, provenientes das mais elevadas áreas da bacia, assim como ocorreu a destruição dos imóveis devido ao impacto da corrida. A magnitude do evento foi tão expressiva que, o rio Santo Antônio, teve seu canal alargado de 10 a 20 m para 60 a 80 m (Cruz, 1974), como observado na Figura 32.

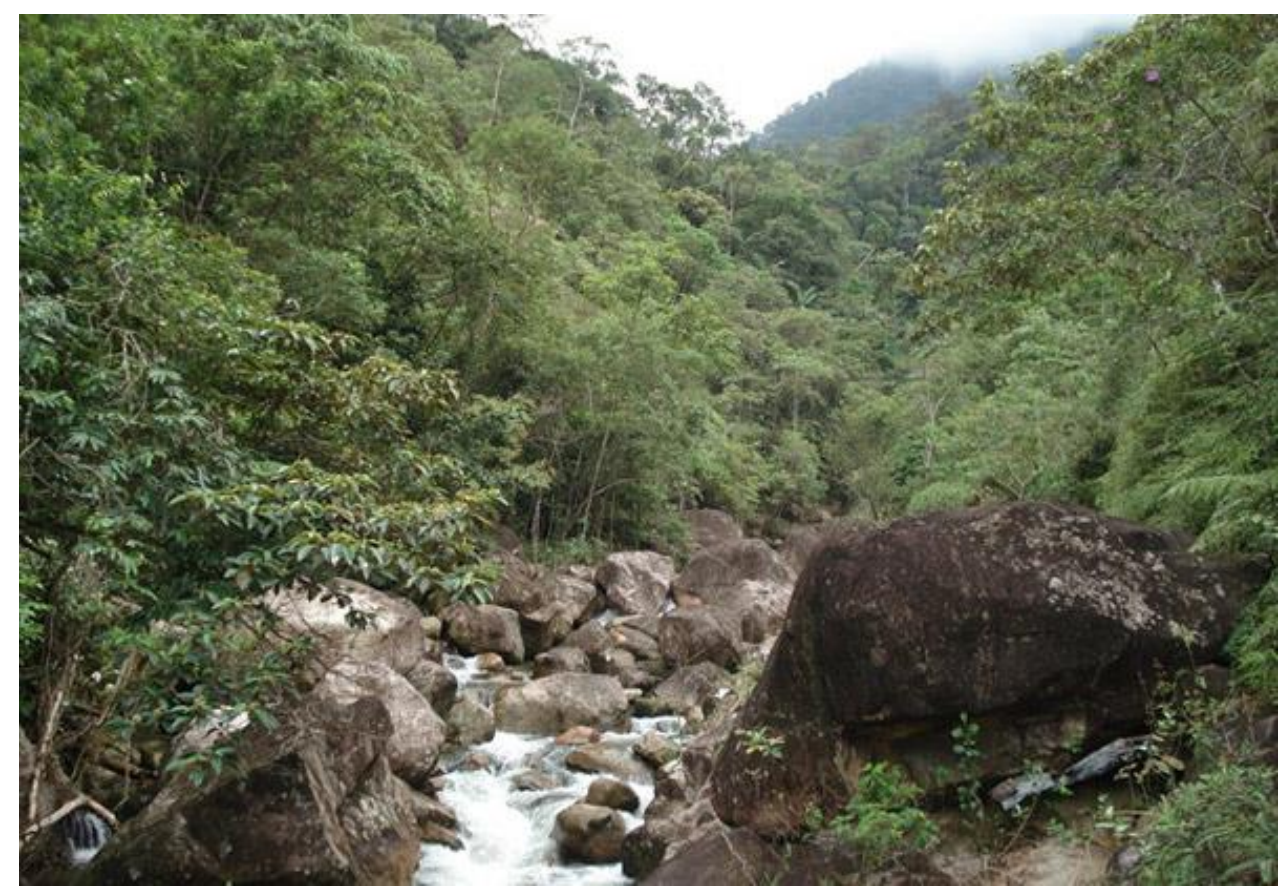

Figura 31: Depósitos de sedimentos grosseiros ao longo do rio Santo Antônio. Local próximo ao estrangulamento da drenagem, que contribui para o acúmulo destes sedimentos, como observado por Cruz (1974). Fonte: Arquivo do Parque Estadual da Serra do Mar - Núcleo Caraguatatuba. 

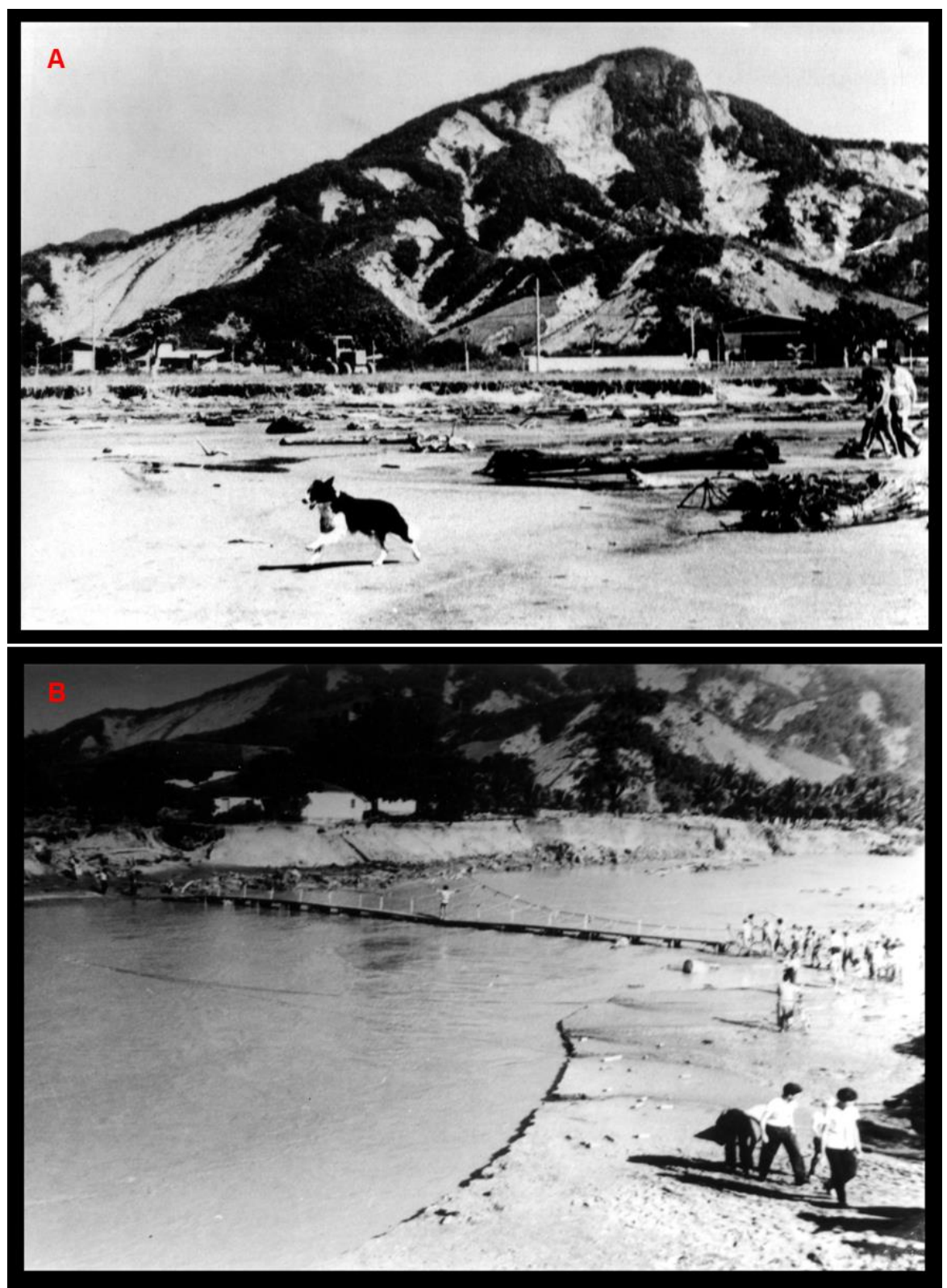

Figura 32: Bacia do rio Santo Antônio. Cicatrizes dos escorregamentos de 1967 no Morro do Tinga (a) e a planície do rio ocupada pelos sedimentos menos grosseiros das corridas de detritos (b). Observam-se troncos de árvores trazidos das partes mais altas (a), bem como o alargamento do rio demostrando a magnitude do evento (b). Fonte: Arquivo Público do município de Caraguatatuba.

As áreas de deposição mapeadas por Cruz (1974) e Dias (2014), para a bacia do rio Guaxinduba foram de 546.011 e $242.522 \mathrm{~m}^{2}$, respectivamente (Figura 33). Dias (2014) observou a presença de blocos com diâmetros variáveis $(<0,5 \mathrm{a}>2,5 \mathrm{~m})$ sendo a maior parte desta deposição localizada no centro da bacia. A disposição dos blocos de diâmetros superiores a $>1,5 \mathrm{~m}$ nas áreas planas da bacia foi 
condicionada pelas características da rede de drenagem da bacia, como observado por Dias (2014).

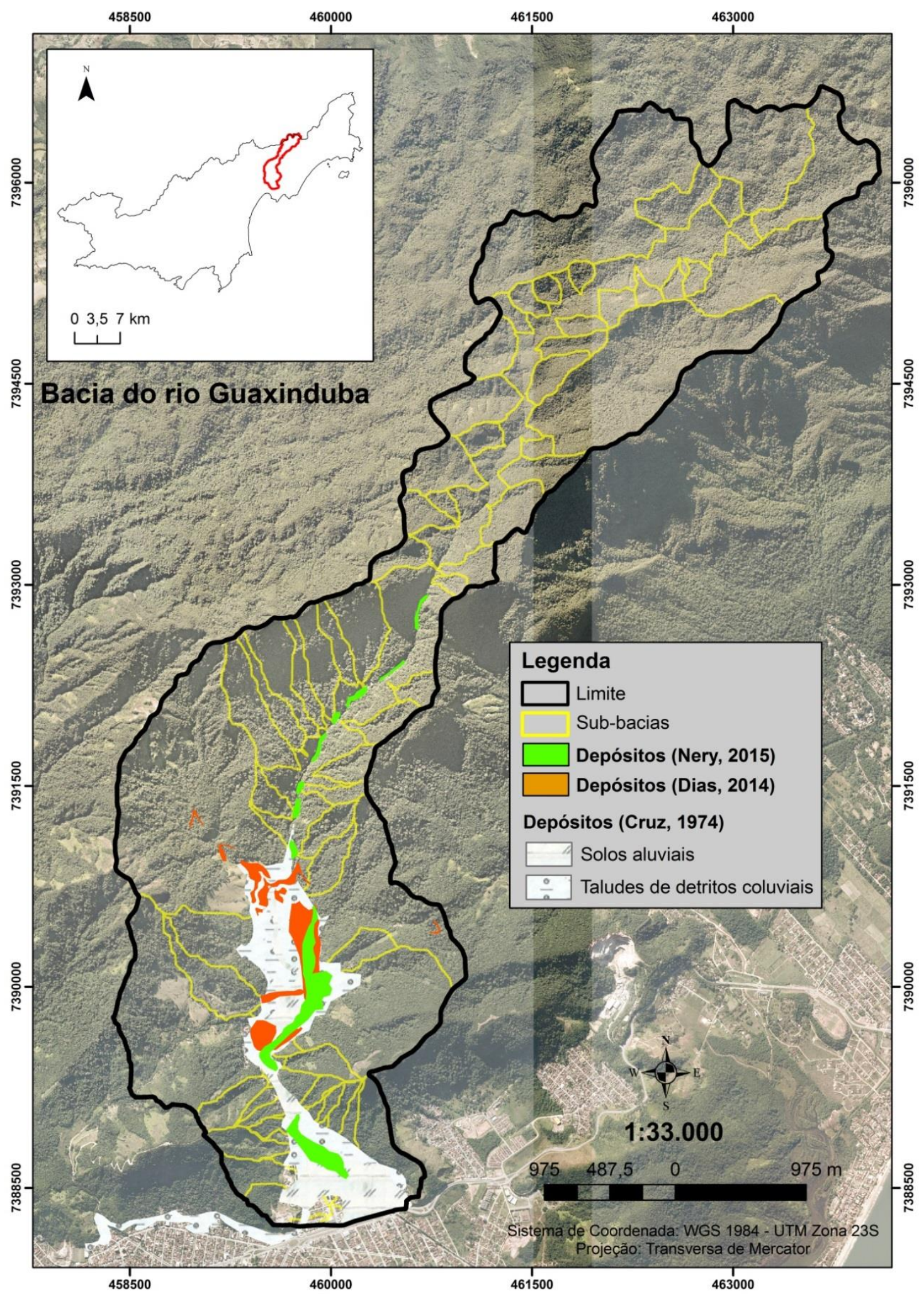

Figura 33: Mapa dos depósitos da bacia do rio Guaxinduba. 
Acredita-se que este comportamento decorreu da alta densidade de drenagem que somada à ocorrência generalizada de escorregamentos nas encostas implicou em maior concentração e escoamento de sedimentos diretamente para o canal principal. Adicionalmente, o desnível abrupto do rio na área da escarpa associado com a intensidade de precipitação, pode ter ocasionado a elevação da vazão dos rios, explicando, assim, a remobilização e o raio de alcance destes materiais mais grosseiros, ao longo e próximos aos canais de drenagem, assim como, a sua deposição nas áreas mais planas da bacia (Figura 34).

A identificação destes processos ao longo do rio principal ou dos canais, por um lado, pode indicar a presença de pequenas rupturas no canal, possibilitando a deposição destes sedimentos nestes locais. Por outro lado, podem também ser reflexo das diferentes fases de erosão do canal, decorrentes dos diferentes pulsos destes processos. De fato, o aumento da vazão do rio, em diferentes momentos, seria responsável pelos estágios de evolução da corrida (pulsos), principalmente na área da escarpa, visto que, não foram identificados depósitos ou zona de arraste acima desta região.

Diferentemente da bacia do rio Santo Antônio, a bacia do Guaxinduba, apresenta apenas um pequeno alvéolo, que segundo Cruz (1974) é recoberto por terraços coluviais e taludes de detritos onde afloram os matacões. A deposição destes materiais localiza-se em sub-bacias com amplitudes entre 280 a $720 \mathrm{~m}$ e, nas proximidades da rede de drenagem, indicando locais com alto potencial de deslocamento em condições de precipitações intensas. Os blocos mais grosseiros depositaram-se neste alvéolo não alcançando a faixa litorânea do município. 

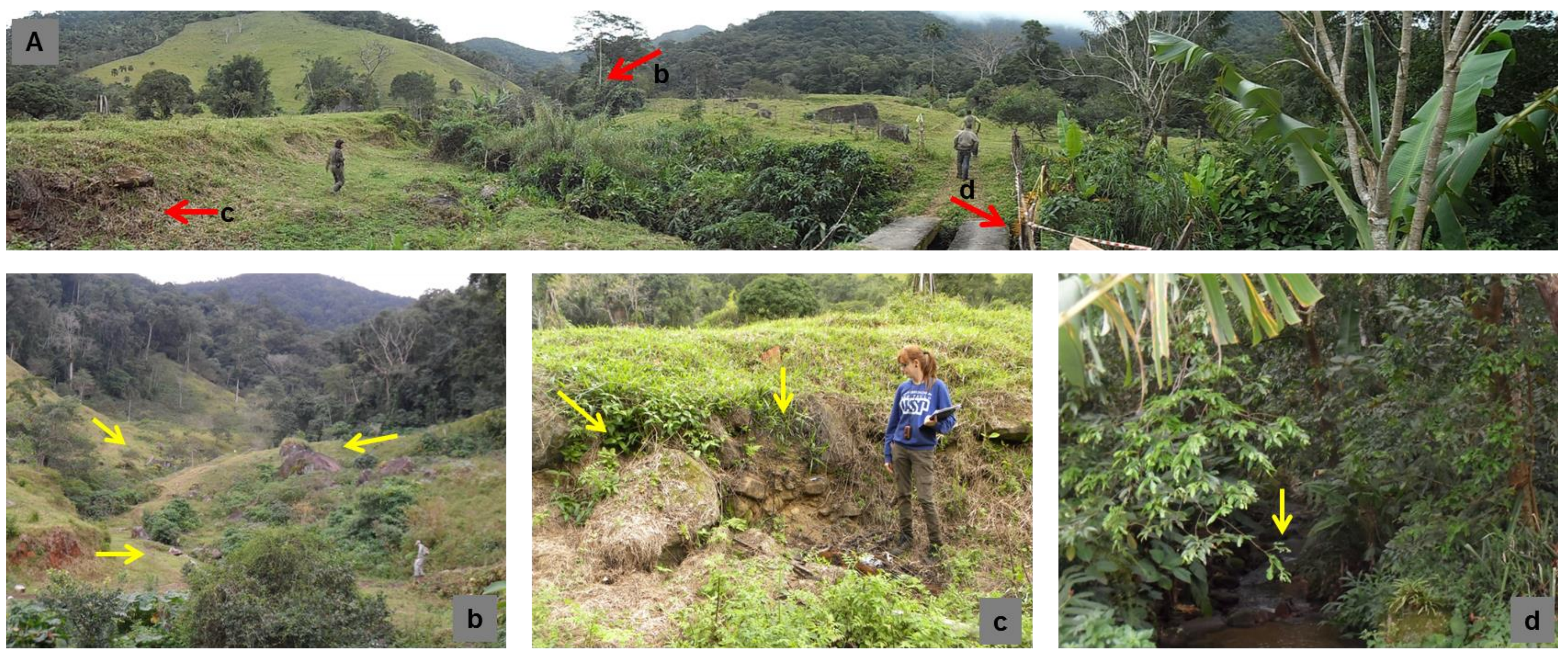

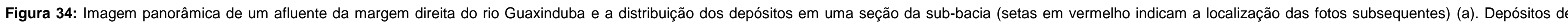

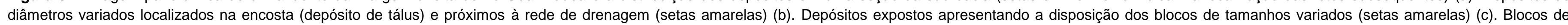
diâmetros menores depositados no leito do canal (seta amarela). Fonte: Bianca C. Vieira. 
A bacia do rio Mococa (Figura 35) apresentou comportamento distinto em relação às demais bacias analisadas. Devido à sua ocupação incipiente, notória até os dias atuais, não foi objeto de estudo para o evento de 1967, mesmo com a ocorrência de escorregamentos e corridas de detritos. O pronunciamento dos alvéolos observados por Cruz (1974) nas bacias do Santo Antônio e Guaxinduba não foram observados na bacia do Mococa.

A montante da bacia, próximos às escarpas, os depósitos concentraram-se no canal principal, ocorrendo também em canais de ordens inferiores. Muitos destes depósitos se encontram em rupturas de declive do canal possibilitando, provavelmente, o acúmulo destes sedimentos. Situação semelhante foi observada na bacia do rio Guaxinduba podendo indicar que, nesta bacia, também houve diferentes estágios de evolução da corrida de detritos.

A jusante da bacia do rio Mococa, a presença dos depósitos foi mínima em termos de área, se comparados com os depósitos das outras bacias. A Figura 36 mostra a presença destes depósitos no pé da escarpa, bem como, a sua aparente ausência, ao longo da rede de drenagem e próxima à área ocupada da bacia. Este comportamento, em relação à seleção dos sedimentos observados por Dias (2014), demonstra que as características da rede de drenagem, da declividade e os diferentes picos de vazão do rio foram determinantes na deposição destes materiais mais grosseiros próximos ao trecho de escarpa e mais finos nas áreas mais planas da bacia. 


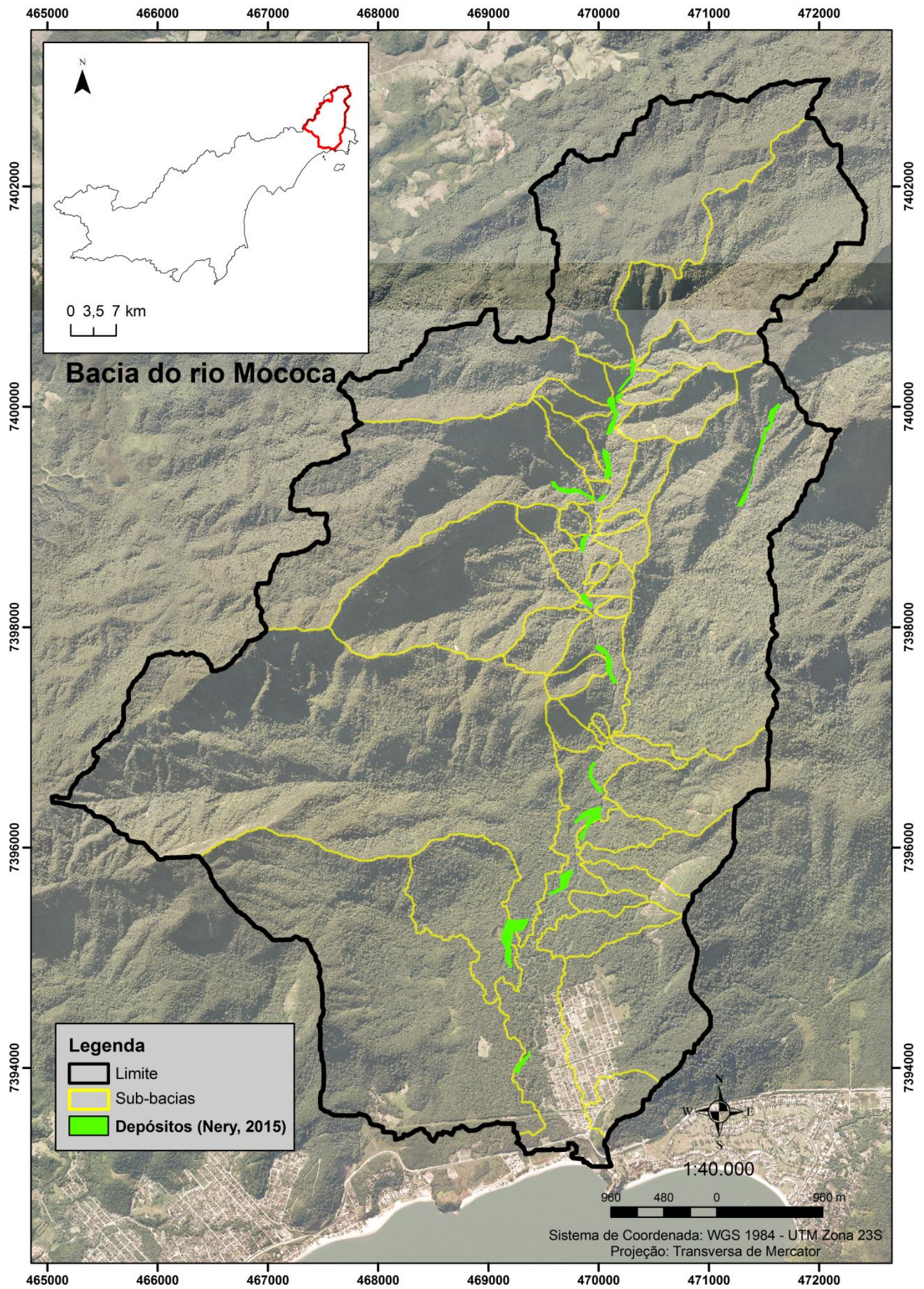

Figura 35: Mapa de depósitos da bacia do rio Mococa. 

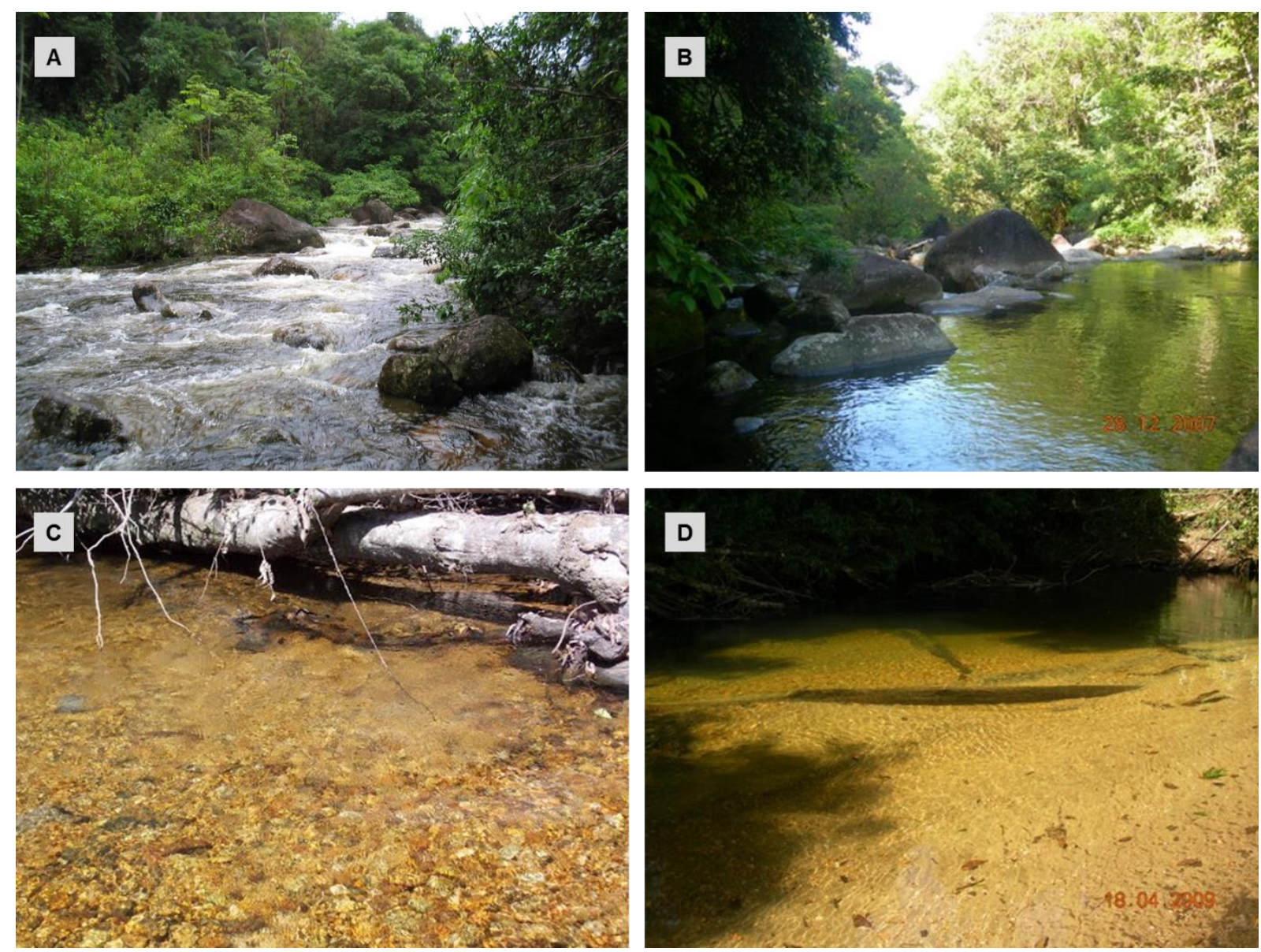

Figura 36: Depósitos de sedimentos grosseiros ao longo do rio Mococa próximo à região de escarpa ( $a$ e b). Trecho do rio Mococa próximo ao residencial Mar Verde, demonstrando a ausência aparente, de sedimentos mais grosseiros (c e d). Fonte: Panoramio

Assumindo as colocações de Augusto Filho et al (2005) e Conq et al. (2015), que consideraram que a espessura dos depósitos das corridas de detritos, em média, seria de $2 \mathrm{~m}$, calculou-se o volume para ás áreas identificadas para as bacias em análise. Desta forma, o depósito para a bacia do Santo Antônio apresentou um volume de $1.262 .926 \mathrm{~m}^{3}$, o da bacia do Guaxinduba volume de $457.590 \mathrm{~m}^{3}$ e a bacia do Mococa volume da ordem de $461.750 \mathrm{~m}^{3}$.

O total de sedimentos para as três bacias foi de $2.182 .265,52 \mathrm{~m}^{3}$, para o evento de 1967. A Figura 37 apresenta os valores estimados a partir dos dados de Cruz (1974) e Dias (2014), onde também empregou-se o valor de $2 \mathrm{~m}$ de deposição e, Fúlfaro et al. (1976). O volume de sedimentos apresentados na figura decorre, primeiramente, ao tamanho da área identificada por cada autor, o que implicaria um alto valor para esta correlação, ou seja, quanto maior a área, maior será o seu 
volume. Considera-se ainda, o tempo de identificação destes processos, visto que, o mapeamento aqui realizado deu-se a partir de fotografias aéreas tomadas 6 anos após o evento, ou seja, muito do material sedimentar ou as áreas de deposição observados por Cruz (1974) e Fúlfaro et al. (1976) não foi identificada. Além disso, a adoção de uma espessura média para toda área mapeada pode influenciar, mesmo sabendo que a deposição não apresenta o mesmo comportamento em toda a sua extensão.

Independentemente do método empregado para a estimativa destes depósitos, por fotointerpretação ou em campo, os resultados mostraram a magnitude deste evento, decorrente do período chuvoso de 1966-1967 ao longo da faixa leste do sudeste brasileiro, culminando em inúmeros escorregamentos. Estes somados ao escoamento concentrado e difuso e ao aumento da vazão dos rios facilitou o transporte dos sedimentos ao longo da rede de drenagem destas bacias, originando uma paisagem caótica, como observado por Domingues et al. (1971) e Cruz (1974).

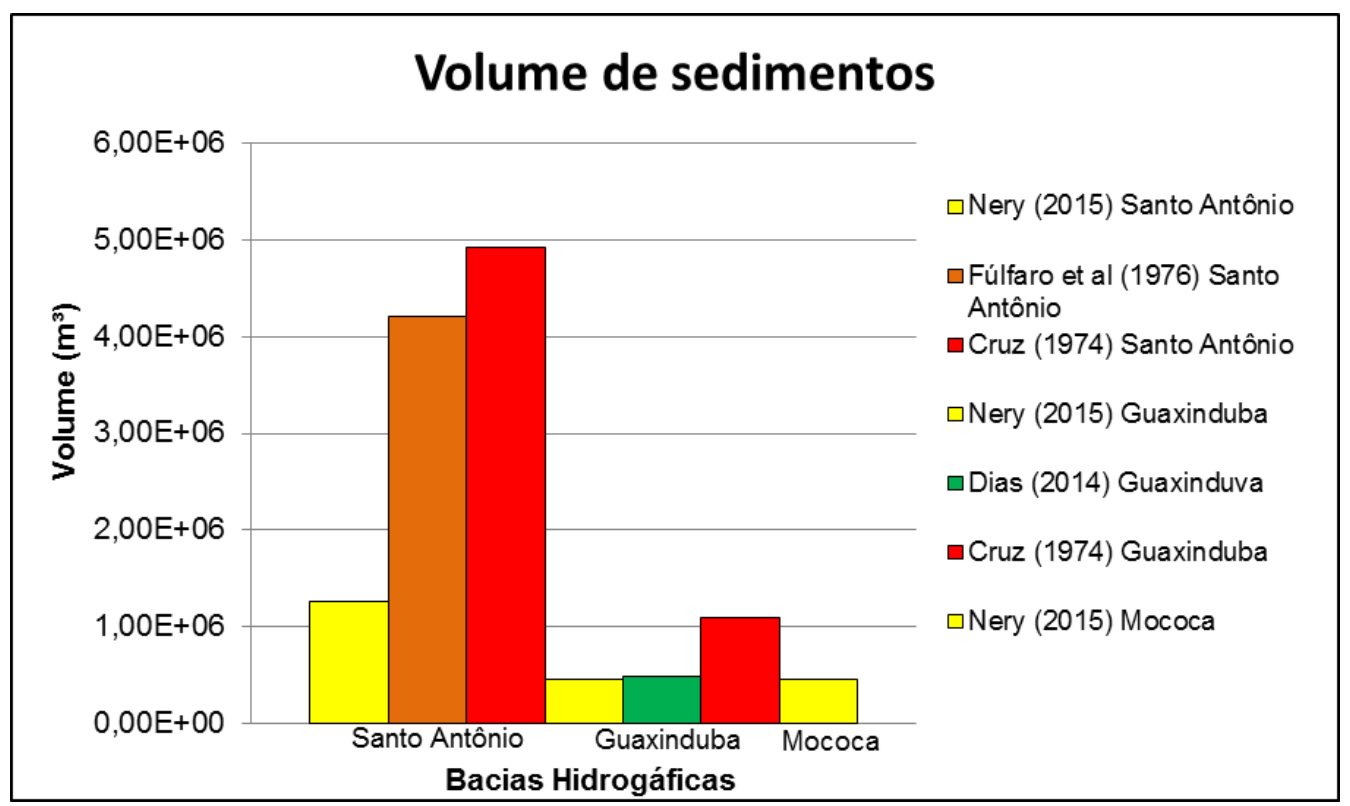

Figura 37: Volume de sedimentos para as bacias analisadas. Os valores observados indicam a magnitude do evento para a bacia do Santo Antônio. Inversamente, a bacia do Mococa apresentou valores de sedimentos próximos aos valores observados para a bacia do Guaxinduba. 
Analisando os resultados do volume de sedimentos dos depósitos e das cicatrizes, como por exemplo para as sub-bacias do rio Santo Antônio (1, 2 e 5), observou-se que os escorregamentos deflagrados nestas sub-bacias podem ter contribuído entre $26 \%$ a $86 \%$ com o volume de sedimentos das corridas de detritos. Entre os resultados encontrados, destaca-se o caso da sub-bacia 2, onde verificouse a maior concentração de escorregamentos (43), com um volume na ordem de $228.362 \mathrm{~m}^{3}$, mas com um volume de deposição de apenas $60.034 \mathrm{~m}^{3}$, resultando na menor contribuição para as corridas (no caso, 26\%). Tal situação implica que nem todos os escorregamentos deflagrados nesta sub-bacia contribuíram no fornecimento de sedimentos para as corridas de detritos.

Esta situação também foi observada na bacia do rio Mococa, onde os escorregamentos podem ter contribuído com valores entre $23 \%$ a $73 \%$ no volume de sedimentos das corridas. Como observado para a sub-bacia 2 do rio Santo Antônio, a sub-bacia 5 (rio Mococa) mostrou o mesmo comportamento, ou seja, uma maior contribuição no volume de sedimentos dos escorregamentos $\left(43.520 \mathrm{~m}^{3}\right)$, porém com um depósito das corridas de detritos na ordem de $31.959 \mathrm{~m}^{3}$, resultando em uma diferença de $73 \%$.

Como apontado e também verificado por Fúlfaro et al. (1976), nem todo o escorregamento na Serra do Mar contribui com a dinâmica das corridas, podendo estes sedimentos depositarem-se na própria encosta ou até mesmo nos canais de drenagem. Estes depósitos podem servir de barragem para os sedimentos provenientes das regiões a montante da bacia para um determinado evento no futuro. Contudo, estas barragens naturais, quando associadas aos sedimentos provenientes das encostas e da rede de drenagem, em condições hidroclimatológicas extremas, podem se romper. Consequentemente, esta situação pode potencializar a dinâmica das corridas e, assim aumentar a magnitude destes fenômenos. Acredita-se, portanto, que a distribuição espacial e o volume de precipitação para os dias do evento podem ter favorecido o comportamento dos movimentos de massa nas bacias, contribuindo com a magnitude deste. 


\subsection{Identificação dos parâmetros e índices morfométricos e morfológico das bacias}

A Tabela 3 apresenta os parâmetros e índices morfométricos. As bacias apresentaram áreas entre $19 \mathrm{~km}^{2}$ (Guaxinduba) e $37 \mathrm{~km}^{2}$ (Santo Antônio e Mococa, cada uma) indicando uma alta probabilidade de áreas fontes de materiais. Alguns autores, como Jackson (1987) e Slaymaker (1990) apontaram que as bacias mais propensas à ocorrência de corridas de detritos variam entre $0,1 \mathrm{a} 12 \mathrm{~km}^{2}$ de área.

Tabela 3: Parâmetros e índices morfométricos e morfológicos das bacias.

\begin{tabular}{cccc}
\hline Parâmetros & Santo Antônio & Guaxinduba & Mococa \\
\hline Área da bacia $\left(\mathrm{km}^{2}\right)$ & 37,0 & 19,0 & 37,2 \\
Amplitude $(\mathrm{m})$ & 910 & 970 & 1070 \\
Comprimento total da drenagem $(\mathrm{km})$ & 140 & 59 & 159 \\
Comprimento do rio principal $(\mathrm{km})$ & 12,3 & 11,2 & 13.4 \\
Declividade média do canal principal $\left({ }^{\circ}\right)$ & 3,85 & 4,56 & 4,25 \\
Densidade de drenagem $\left(\mathrm{km}^{2} / \mathrm{km}^{2}\right)$ & 3,8 & 3,1 & 4,2 \\
Índice de circularidade (adimensional) & 0,41 & 0,21 & 0,37 \\
Área total da bacia acima de 30 $(\%)$ & 32,42 & 33,97 & 37,15 \\
Ângulo médio das encostas $\left({ }^{\circ}\right)$ & 25 & 25 & 25 \\
$\mathrm{~N}^{\circ}$ de escorregamentos & 106 & 51 & 75 \\
Densidade de escorregamentos $\left(\# / \mathrm{km}^{2}\right)$ & 2,8 & 2,7 & 1,6 \\
\hline
\end{tabular}

O entendimento sobre a ocorrência das corridas de detritos em grandes bacias, segundo Mizuyama (1982) só podem ser compreendidas em escalas de subbacias (geralmente áreas inferiores a $1 \mathrm{~km}^{2}$ ), pois a relação entre a produção e a vazão dos sedimentos ocorrem quase de forma igualitária. Ou seja, uma parcela destes sedimentos é depositada nestas áreas formando os leques aluviais e o restante escoa e deposita-se mais a jusante (MIZUYAMA, 1982). Neste contexto, os sedimentos que escoam das grandes bacias, em relação ao total de sedimentos produzidos pelas suas sub-bacias é consideravelmente menor, principalmente os sedimentos mais grosseiros (MIZUYAMA, 1982).

Jackson (1987) exemplifica que bacias maiores em uma determinada seção apresentam maior largura média e um decréscimo da declividade média do canal em relação às bacias menores. Consequentemente, esta condição diminui o 
deslocamento dos sedimentos mais grosseiros para as áreas mais planas da bacia predominando assim os sedimentos mais finos (JACKSON, 1987). Esta situação fora bem exemplificada na bacia do rio Santo Antônio, pela forma de deposição dos sedimentos observados por Cruz (1974), que verificou uma maior concentração de sedimentos finos entre o primeiro e segundo alvéolo.

Sobre a ocorrência de corridas de detritos em bacias superiores a $10 \mathrm{~km}^{2}$, Jakob (1996), em estudos realizados no sudeste da Columbia Britânica, observou que estes processos podem ocorrer também devido à mudança abrupta da declividade, principalmente na parte mais a jusante do canal e/ou decorrente da barragem natural de sedimentos que, durante a deflagração de um escorregamento ou por meio de vazões de pico elevadas do canal, levou a ocorrência destes processos. Acredita-se que esta situação ocorreu nas bacias analisadas, visto as observações ou relatos destas deposições de sedimentos grosseiros associadas à ruptura da rede de drenagem.

Por mais que a área da bacia seja um parâmetro significativo, esta variável não pode ser empregada como único critério para distinguir bacias com ou sem ocorrência de corridas de detritos, como observado por Jakob (1996). No entanto, a área da bacia contribui para as características da vazão e produção de sedimentos e, podem dar a dimensão do evento.

O deslocamento das corridas de detritos depende também da amplitude da bacia, pois quanto maior for o seu valor, maior será a energia potencial para o escoamento do material (IPT, 2002). A ocorrência de diferentes processos morfodinâmicos, entre eles, as corridas de detritos e as inundações, associados à amplitude, foram encontradas em outras regiões do mundo, entre elas, Argentina, Itália, Taiwan. Sub-bacias com amplitudes entre 310 e $731 \mathrm{~m}$ associadas à ocorrência de corridas de detritos foram observadas por Melelli e Tamarelli (2004), na região de Úmbria, Itália. Chen e Yu (2011) observaram a ocorrência de corridas de detritos associadas a bacias e sub-bacias com amplitudes entre 882 e 1761 na parte central e norte de Taiwan. Perucca e Angilieri (2011) observaram que devido amplitude de 3895 m, a bacia Del Molle, Argentina, apresentou alto potencial a ocorrência de processos de enxurradas/inundações bruscas. 
A amplitude para as bacias analisadas variou entre 900 (Guaxinduba e Santo Antônio) e 1070 m (Mococa), apresentando-se como um bom indicativo do potencial para o escoamento superficial e para o transporte de sedimentos, principalmente em eventos extremos. Nestas condições, quando associadas a altas declividades e altos índices de densidade de drenagem, acredita-se que haveria uma maior vazão dos rios (BRUBACHER et al., 2011), contribuindo diretamente para um maior escoamento dos sedimentos, podendo alcançar maiores distâncias ao longo da rede de drenagem.

As bacias dos rios Santo Antônio e Mococa apresentaram uma rede de drenagem entre 140 e $159 \mathrm{~km}$, respectivamente. O total deste parâmetro para a bacia do rio Guaxinduba representou quase a metade $(59 \mathrm{~km})$. Foram identificados os seguintes comprimentos dos rios principais: $11 \mathrm{~km}$ (Guaxinduba), $12 \mathrm{~km}$ (Santo Antônio) e 13 km (Mococa). Para IPT (2002), esta situação reflete em uma maior presença de depósitos ao longo da rede de drenagem, consequentemente maior seria o volume de sedimentos disponível para a remobilização em eventos futuros. Esta situação decorre do aumento e da diminuição da vazão dos rios, na qual, contribui para a remobilização e deposição destes sedimentos ao longo da drenagem.

Esta mesma situação foi observada por Jakob (1996) que verificou que quanto maior for o comprimento da drenagem, maior o armazenamento de sedimentos nestes canais. Observações realizadas por Santi et al. (2008) em 9 bacias na Califórnia, Colorado e Utah, para 46 corridas de detritos, demonstraram que a produção de sedimentos variou entre 0,30 a $9,93 \mathrm{~m}^{3}$ por cada metro de comprimento do canal, gerando volumes entre 174 e $59.281 \mathrm{~m}^{3}$. Neste sentido, o maior comprimento e inclinação dos canais analisados nesta pesquisa levaram a maior taxa de erosão e de deposição e, consequentemente aumentou a vazão e o volume de sedimentos, aumentando o impacto do evento.

A declividade média do canal, segundo Augusto Filho (1993), influencia a capacidade de erosão e a mobilização do material depositado ao longo da rede de drenagem. Assim, quanto maior for à declividade média, maior será o fluxo da corrente e, consequentemente, maior será o potencial de geração de corridas. Neste 
sentido, os canais principais das bacias tenderam a uma maior probabilidade de acúmulo de sedimentos, visto que as declividades dos canais variaram entre $3^{\circ}$ e $5^{\circ}$ e, assim, podem se transformar em possíveis áreas fontes em eventos futuros. Conforme nos explicitam Neetleton et al. (2005), de fato a extensão e a declividade do canal podem levar à ocorrência de zonas de deposição e de erosão ao longo do canal, podendo variar com a intensidade dos diferentes estágios da inundação. Para tais autores, tal situação é decorrente da forma, do padrão e da presença de barramentos, naturais ou artificiais, ao longo da rede de drenagem que influenciam no volume e na trajetória destes sedimentos.

Em relação à densidade de drenagem, as bacias apresentaram um alto índice de densidade de drenagem, entre 3 e $4\left(\mathrm{~km} / \mathrm{km}^{2}\right)$ configurando, segundo Yildiz (2004), bacias de resposta hidrológica rápida quando associadas a eventos de precipitação, servindo, segundo Hasegawa et al. (2013), como um bom indicativo para identificar aquelas mais propensas à ocorrência das corridas de detritos.

Hasegawa et al. (2013) estudaram os escorregamentos rasos e as corridas de detritos no sudoeste do Japão. Observaram que tais processos em bacias com altos valores de densidade de drenagem necessitam de um menor índice de precipitação e, inversamente, bacias com baixa densidade de drenagem necessitam de um maior índice de precipitação para a deflagração das corridas de detritos. Esta situação, por um lado, pode indicar que as corridas de detritos em bacias com alto valor de densidade de drenagem tendem a ser deflagradas no próprio canal de drenagem. Por outro lado, a deflagração destes processos em bacias com baixo valor de densidade de drenagem dependeria da ocorrência de outros processos, no caso, os escorregamentos.

Perucca e Angilieri (2011) observaram que valores altos de densidade de drenagem podem levar a ocorrência de fluxo concentrado superficial, incrementando, conforme Brubacher et al. (2013), o efeito de enchentes. Segundo Jackson (1987), tais fluxos quando associado à deflagração de corridas de detritos transportam grande quantidade de sedimentos em um curto espaço de tempo. Para este autor, sem a ocorrência de precipitação intensa, somada a deflagração destes processos, seriam necessários muitos anos de erosão e de transporte de volume de 
sedimentos para igualar-se a quantidade de materiais provenientes das corridas de detritos. Neste sentido, os depósitos encontrados nas áreas planas das bacias do Santo Antônio e do Guaxinduba podem servir como testemunho do comportamento deste índice para o transporte destes sedimentos.

Quanto ao índice de circularidade os valores foram inferiores a 0,5, podendo apontar para um maior tempo de concentração do escoamento dentro destas bacias e indicando baixa possibilidade de elevação dos canais, como pontuado por De Matauco (2004). Portanto, por meio deste índice, tais bacias não apresentariam condições de deflagração das corridas de detritos iniciadas nestes canais. Essas observações estão de acordo com as observações feitas por Augusto Filho (1993). Segundo o autor, as bacias mais favoráveis a ocorrência das corridas de detritos seriam aquelas com índices próximos a 1 devido ao menor tempo de concentração.

No entanto, há uma incerteza em relação a este índice, visto que, em condições de precipitação intensa e de longa duração há o aumento do nível do canal, remobilizando o material depositado (RICKENMANN e ZIMMERMANN, 1993). Casos como este foram observados na Suíça por Conedera et al. (2003) que evidenciaram a ocorrência de corrida de detritos em uma bacia com índice de 0,34 após precipitação intensa. Sterling e Slaymaker (2007) observaram a ocorrência de corridas de detritos, na Columbia Britânica, em bacias com índices entre 0,15 e 0,5 associadas a elevados índices de precipitação diários, em um período de 30 anos. No norte e centro de Taiwan, Chen e Yu (2011), observaram a ocorrência destes processos em bacias com índice de forma entre 0,26 a 2,07 decorrentes de precipitações intensas, após a passagem de tufões. Da mesma forma, o evento de 1967 em Caraguatatuba foi caracterizado por precipitações intensas (aproximadamente 600 mm em 48 horas), ratificando a baixa influência do índice de circularidade em corridas de detritos em eventos de grande magnitude.

A respeito do ângulo da encosta, houve variação entre $<30^{\circ} \mathrm{a}>50^{\circ}$, com média de $25^{\circ}$. O intervalo entre $30^{\circ}$ a $40^{\circ}$ foi a segunda classe que mais concentrou escorregamentos para as bacias do Mococa (30\%), Guaxinduba (29\%) e Santo Antônio (28\%). Lan et al. (2004) observaram que este intervalo (30 e $40^{\circ}$ ) foi a segunda classe mais afetada pelos escorregamentos em seu estudo, com $0,6 \%$, na 
bacia do rio Xiaojiang, sudoeste da China. Assim como, nas bacias aqui estudadas este valor para as classes acima de $50^{\circ}$ apresentou decréscimo para este índice.

Em geral, a Serra do Mar apresenta predomínio de declividades entre $30^{\circ}$ a $40^{\circ}$ (IPT, 1986), e de acordo com Uehara et al. (2008) e Gramani (2013), locais acima de $30^{\circ}$ são mais propensos à ocorrência dos escorregamentos e corridas de detritos na Serra do Mar. No entanto, Cruz (1990) observou a ocorrência de escorregamentos para as escarpas da Serra do Mar, em Caraguatatuba, em encostas a partir de $22^{\circ}$. Porém ocorrências destes processos, associados a intervalos inferiores a estes, representaram apenas $2 \%$ para o evento de 1967 . Um baixo índice para este intervalo também foi observado por Shahabi et al. (2012) que não identificaram ocorrência de escorregamentos para ângulos inferiores a $22^{\circ}$, na bacia de Zab, sudoeste de Azerbaijão. Na Serra do Mar Paranaense, Silveira et al. (2013) identificaram que encostas superiores a $30 \%\left(17^{\circ}\right)$, associadas a cota altimétrica superiores a $400 \mathrm{~m}$, tendem a ser mais suscetíveis a deflagração de corridas de detritos e escorregamentos.

Encostas superiores a $30^{\circ}$ representam 37\% da bacia do Mococa, 33\% do Guaxinduba e 32\% do Santo Antônio. As bacias (Figuras 38 e 39) apresentaram alto índice de Concentração de Cicatrizes (CC) para os ângulos inferiores a $30^{\circ}$, principalmente para as bacias do Santo Antônio e Guaxinduba, com 51\% e 48\%, respectivamente. A bacia do Mococa apresentou índice de 35\%. Resultado similar foi observado por Coe et al. (2004) na Guatemala, onde $96 \%$ dos escorregamentos ocorreram entre $16^{\circ}$ a $44^{\circ}$, sendo o maior percentual (11\%) associado ao intervalo de $26^{\circ}$ a $28^{\circ}$.

Acredita-se que o elevado índice para esta classe $\left(<30^{\circ}\right)$ decorreu do método adotado na delimitação destas feições, o qual contribui para a inserção de cicatrizes nessas declividades inferiores, superestimando a concentração para estas classes. Exemplo desta situação foi o morro do Jaraguá, no sudoeste da bacia do rio Santo Antônio, onde o processo ocorreu por toda encosta, abrangendo os diferentes intervalos. 

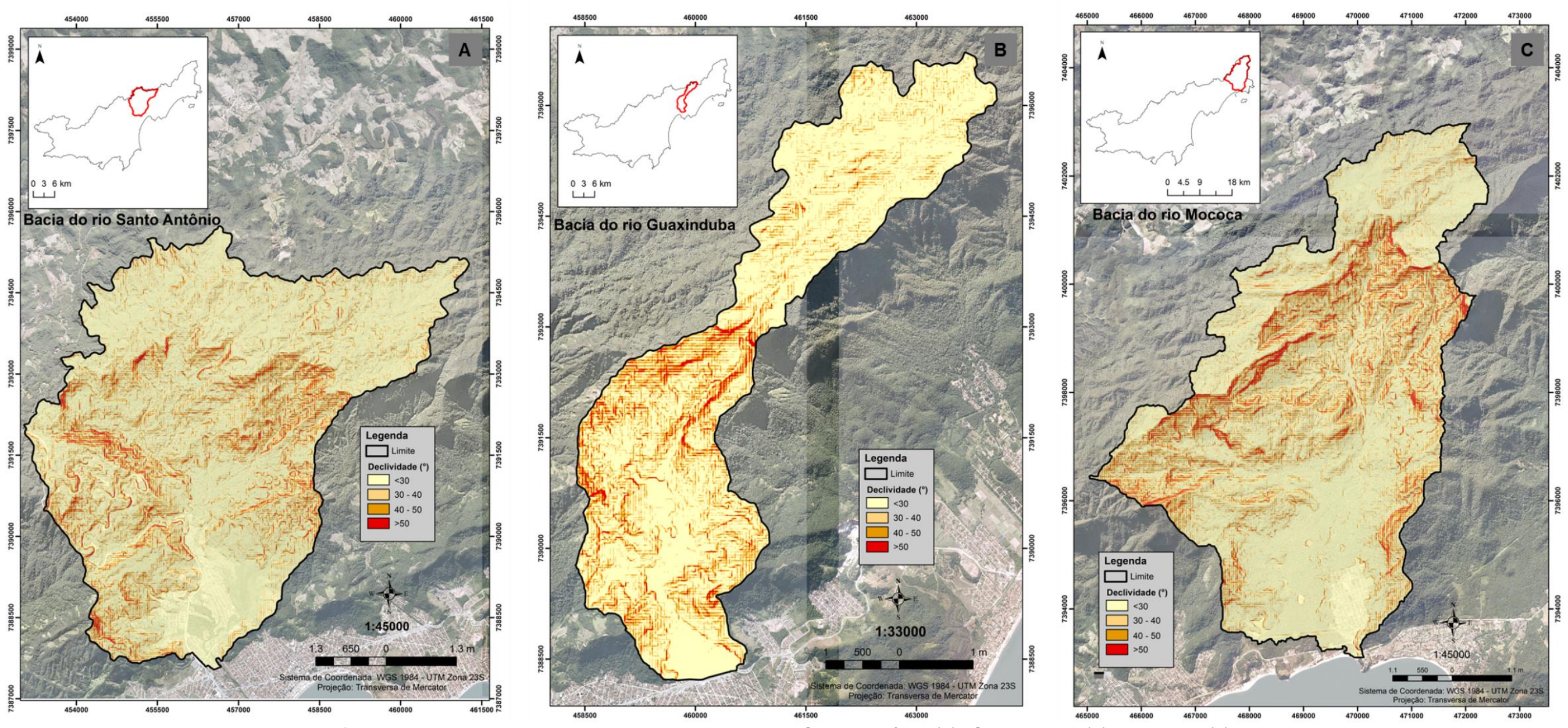

Figura 38: Mapa de declividade das bacias dos rios Santo Antônio (a), Guaxinduba (b) e Mococa (c). 


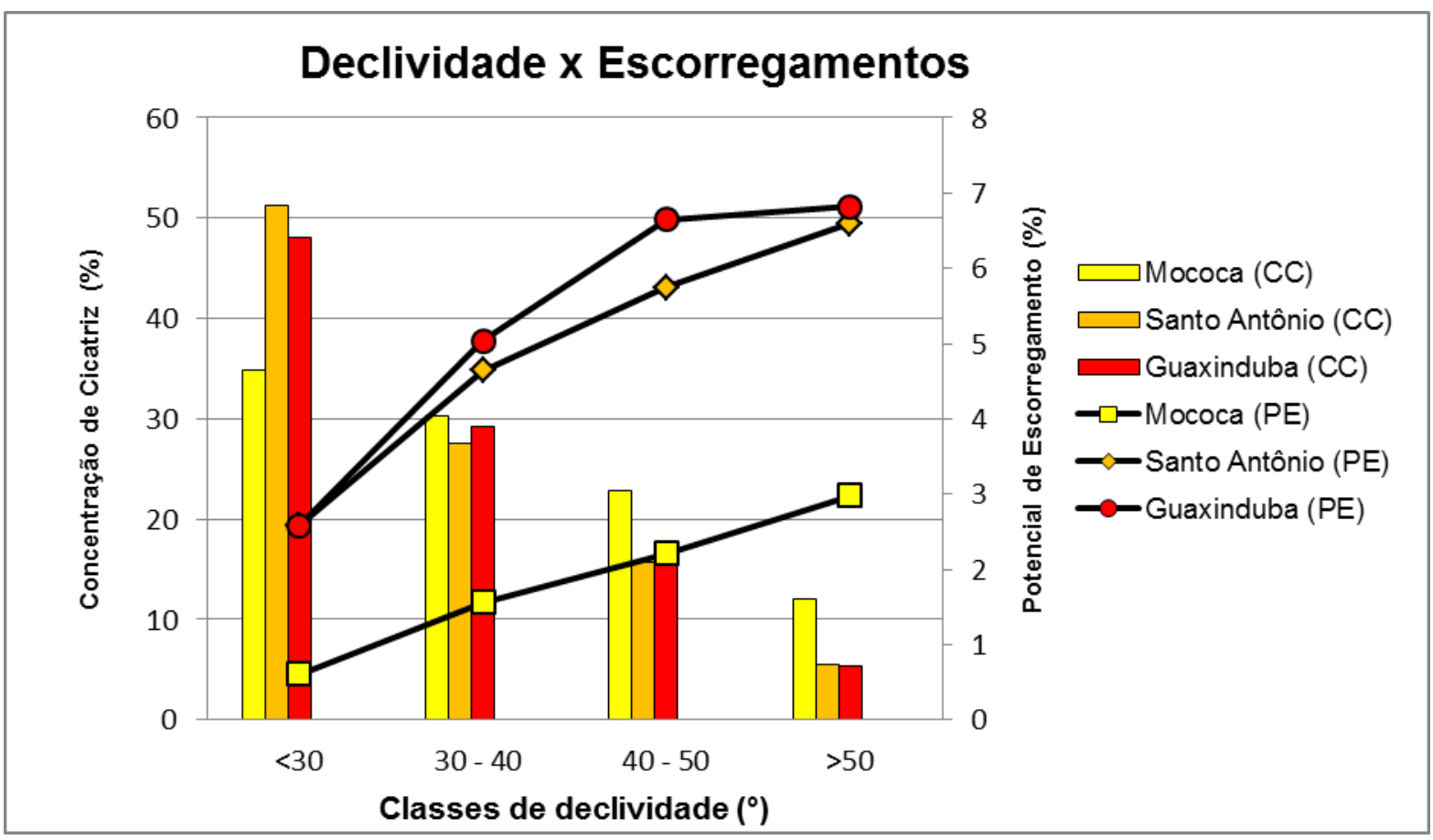

Figura 39: Gráfico apresentando a distribuição dos escorregamentos em relação às classes de declividades. Os escorregamentos concentraram-se entre os intervalos de 15 a $45^{\circ}$, com o potencial de escorregamento entre as classes de 15 a $60^{\circ}$.

Quanto aos valores de Potencial de Escorregamentos (PE) (Figura 39) os resultados obtidos apresentaram uma correlação positiva deste índice com a declividade, com a curva se estabilizando após o intervalo $>50^{\circ}$, como também foi observado por Dymond et al. (2006). Estes autores verificaram na Nova Zelândia, que a probabilidade de ocorrência de escorregamentos aumentou de forma quase linear e constante até o intervalo de $60^{\circ}$, com posterior declínio. O maior valor obtido para esta análise, por estes autores, foi de $1,8 \%$ associado a encostas com declividades de $50^{\circ}$.

Para os intervalos superiores a $50^{\circ}$ os valores variam entre $3 \%$ a $7 \%$. Contudo, estes intervalos para a Serra do Mar são áreas restritas, onde a espessura do solo tende a ser rasa ou onde ocorrem afloramentos rochosos (AUGUSTO FILHO et al., 2005), e consequentemente apresentariam baixa probabilidade de ocorrência dos escorregamentos que contribuíssem para as corridas de detritos.

De fato, devido à ocorrência generalizada de escorregamentos em várias encostas ou pelo método adotado, acredita-se que isso tenha influenciado nos altos 
valores dos índices CC e PE independentemente de serem as classes mais propensas à deflagração dos escorregamentos.

Em geral, os parâmetros e índices morfométricos permitiram observar características que podem indicar o potencial de cada bacia na ocorrência das corridas de detritos. As bacias do Santo Antônio e Mococa apresentaram as maiores dimensões de área, permitindo assim uma maior captação de água precipitada em relação à bacia do Guaxinduba. Quando associado ao índice de densidade de drenagem e em condições de precipitações intensas e/ou prolongadas, as bacias do Santo Antônio e Mococa podem apresentar uma maior vazão de escoamento do que a bacia do Guaxinduba, permitindo assim um maior deslocamento destes sedimentos.

No entanto, mesmo que estas bacias apresentem um maior tempo de concentração de escoamento, como observado pelo índice de circularidade, acredita-se que a bacia do Guaxinduba responderia de forma mais rápida em relação às bacias do Santo Antônio e Mococa. Isto se deve a uma menor rede de drenagem, a uma menor extensão do canal principal e devido a sua dimensão de área, o que permitiria uma concentração rápida de água, aumentando a vazão dos rios e, assim contribuindo para um escoamento instantâneo destes sedimentos. Além disso, o percentual de encostas acima de $30^{\circ}$ seria outro fator preponderante em apontar a bacia do Guaxinduba como mais suscetível à ocorrência das corridas de detritos, mesmo esta apresentando o segundo maior valor para este parâmetro.

Acredita-se, que dadas às particularidades de cada bacia e a configuração e distribuição da precipitação, as informações encontradas podem indicar que um ou outro parâmetro, e/ou índice, seja mais significativo para a ocorrência de corridas de detritos, mas ao mesmo tempo tais variáveis só podem ser compreendidas de forma conjunta na ocorrência destes processos, e não de forma isolada. 


\subsection{Análise comparativa das bacias do Santo Antônio e Mococa}

As bacias dos rios Santo Antônio e Mococa, bacias com áreas similares, apresentaram comportamentos diferenciados quanto à ocorrência das corridas de detritos $^{4}$. A hierarquização destas bacias referentes aos parâmetros e aos índices morfométricos, somada à ocorrência de escorregamentos e de corridas de detritos, permitiu identificar 8 de 9 sub-bacias do rio Santo Antônio e 12 de 36 sub-bacias do rio Mococa para esta análise (Tabelas 4 e 5) (Figura 40).

Tabela 4: Parâmetros e índices das sub-bacias do rio Santo Antônio

\begin{tabular}{ccccccccc}
\hline Parâmetros & $1^{*}$ & $2^{*}$ & 3 & 4 & $5^{*}$ & 7 & 8 & 9 \\
\hline Área da bacia $\left(\mathrm{km}^{2}\right)$ & 13,8 & 10,9 & 0,69 & 0,59 & 3,91 & 2,35 & 0,35 & 2,85 \\
Amplitude $(\mathrm{m})$ & 810 & 790 & 380 & 310 & 750 & 340 & 10 & 570 \\
Comp. total da drenagem $(\mathrm{km})$ & 50,0 & 46,2 & 3,34 & 2,74 & 14,9 & 10,2 & 2,12 & 10,5 \\
Comp. do rio principal $(\mathrm{km})$ & 8,26 & 8,21 & 2,72 & 1,48 & 3,66 & 2,95 & 1,32 & 2,60 \\
Decliv. Média do canal principal $\left(^{\circ}\right)$ & 5,05 & 6,04 & 5,66 & 8,78 & 10,37 & 6,36 & 0,43 & 8,08 \\
Densidade de drenagem $\left(\mathrm{km} / \mathrm{km}^{2}\right)$ & 3,62 & 4,21 & 4,80 & 4,59 & 3,82 & 4,35 & 6,14 & 3,67 \\
Índice de circularidade & 0,30 & 0,34 & 0,23 & 0,39 & 0,48 & 0,56 & 0,33 & 0,54 \\
Zona de arraste $(\mathrm{km})$ & 1,8 & 0,91 & $\mathrm{n} / \mathrm{o}$ & $\mathrm{n} / \mathrm{o}$ & 0,81 & $\mathrm{n} / \mathrm{o}$ & $\mathrm{n} / \mathrm{o}$ & $\mathrm{n} / \mathrm{o}$ \\
\hline
\end{tabular}

Depósitos ou zonas de arraste identificados nas sub-bacias $\left(^{*}\right) ;$ n/o= não observado.

Tabela 5: Parâmetros e índices das sub-bacias do rio Mococa.

\begin{tabular}{|c|c|c|c|c|c|c|c|c|c|c|c|c|}
\hline Parâmetro & $3^{*}$ & 4 & $5^{*}$ & 6 & 7 & 9 & 13 & 14 & 17 & 21 & 22 & 33 \\
\hline Área da bacia $\left(\mathrm{km}^{2}\right)$ & 4,0 & 3,0 & 2,8 & 2,3 & 2 & 1,3 & 0,4 & 0,3 & 0,2 & 0,2 & 0,1 & 0,1 \\
\hline Amplitude (m) & 860 & 620 & 730 & 600 & 770 & 560 & 570 & 510 & 370 & 600 & 340 & 430 \\
\hline Comp. T. da drenagem $(\mathrm{km})$ & 16,7 & 11,4 & 10,8 & 8,4 & 8,4 & 4,3 & 1,4 & 1,3 & 1,2 & 0,9 & 0,5 & 0,6 \\
\hline Comp. do rio principal (km) & 4,2 & 4,5 & 3,8 & 3,4 & 2,4 & 2,7 & 1,1 & 1,2 & 0,8 & 0,7 & 0,4 & 0,5 \\
\hline Decliv. Méd. do canal princ. $\left({ }^{\circ}\right)$ & 9,1 & 6,8 & 10,0 & 8,5 & 11,8 & 10,6 & 16,2 & 20,4 & 15,3 & 12,2 & 12,0 & 20,8 \\
\hline Den. de drenagem $\left(\mathrm{km} / \mathrm{km}^{2}\right)$ & 4,07 & 3,87 & 3,79 & 3,71 & 4,33 & 3,18 & 3,48 & 3,82 & 5,27 & 5,09 & 3,38 & 5,24 \\
\hline Índice de circularidade & 0,48 & 0,34 & 0,39 & 0,40 & 0,61 & 0,37 & 0,56 & 0,41 & 0,47 & 0,39 & 0,58 & 0,46 \\
\hline Zona de arraste (km) & 1,02 & $\mathrm{n} / \mathrm{o}$ & 0,47 & $\mathrm{n} / \mathrm{o}$ & $\mathrm{n} / \mathrm{o}$ & $\mathrm{n} / \mathrm{o}$ & $\mathrm{n} / \mathrm{o}$ & $\mathrm{n} / \mathrm{o}$ & $\mathrm{n} / \mathrm{o}$ & $\mathrm{n} / \mathrm{o}$ & $\mathrm{n} / \mathrm{o}$ & $\mathrm{n} / \mathrm{o}$ \\
\hline
\end{tabular}

Depósitos ou zonas de arraste identificados nas sub-bacias $\left(^{*}\right) ; n / 0=$ não observado.

\footnotetext{
${ }^{4}$ Os dados a respeito das sub-bacias do rio Guaxinduba podem ser visualizados no Apêndice II.
} 

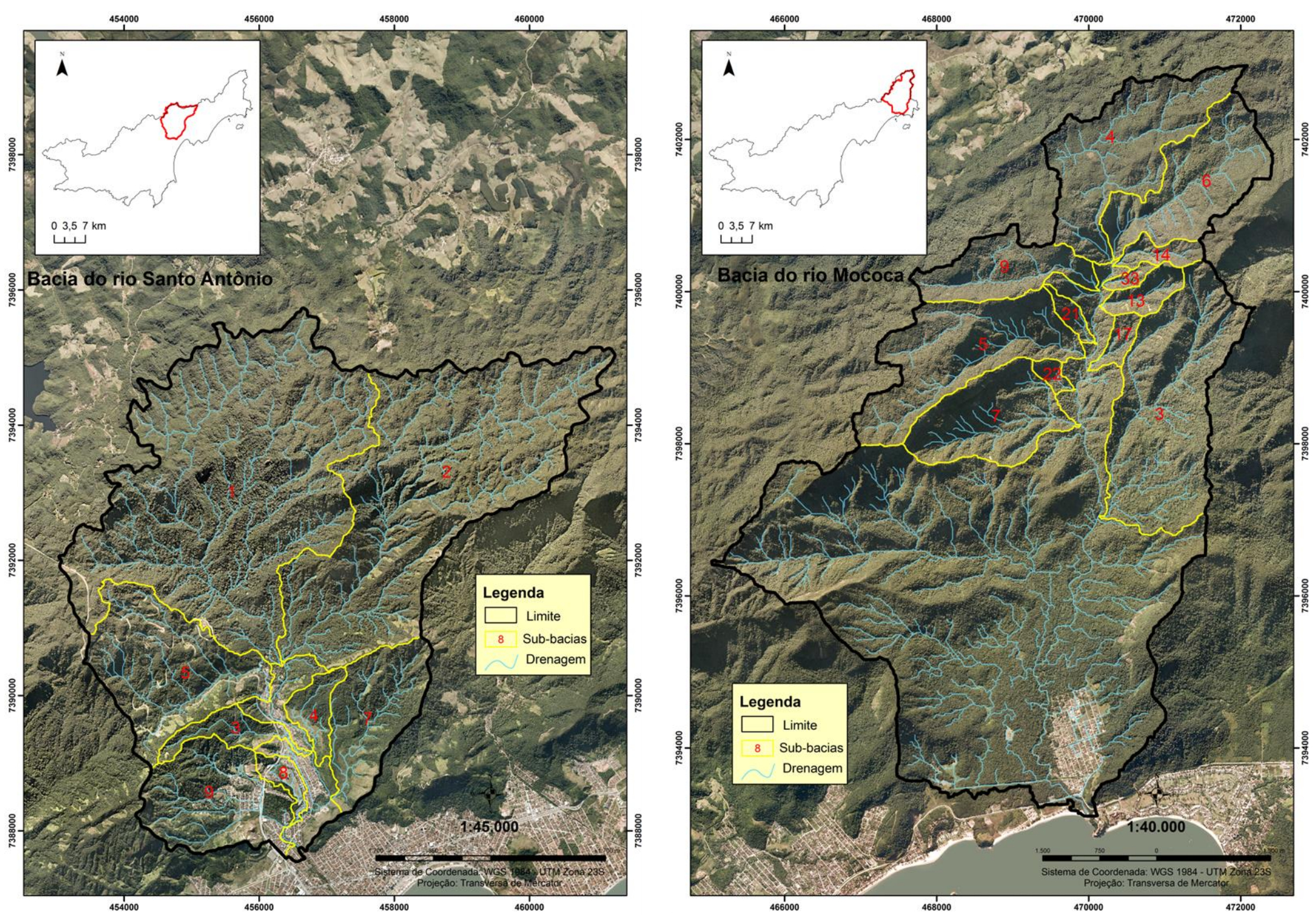

Figura 40: Mapa de localização e identificação das sub-bacias dos rios Santo Antônio e Mococa para análise qualitativa das corridas de detritos. 
Ressaltando, conforme observado na literatura, as bacias ou sub-bacias mais propensas às corridas de detritos apresentam áreas inferiores a $10 \mathrm{~km}^{2}$ (MIZUYAMA, 1982) e amplitudes superiores a 500 m (JACKSON, 1987). Augusto Filho (1993), salienta que bacias favoráveis a ocorrência destes processos iniciadas nos canais de drenagem, devem apresentar índice de circularidade próximo a 1.

Nesta lógica, apenas a sub-bacia 1 do rio Santo Antônio não seria propensa a ocorrência destes processos, por apresentar área de $14 \mathrm{~km}^{2}$. Contudo, assim como nas sub-bacias 2 e 5, para a bacia do Santo Antônio e 3 e 5 para a bacia do Mococa, foi observada a ocorrência de corrida de detritos na sub-bacia 1, corroborando com Jakob (1996), que aponta que bacias desta ordem de grandeza também possuem maior probabilidade a este tipo de processo. De fato, como observado por Chang e Chien (2007), a ordem de grandeza das bacias ou subbacias acarreta uma quantidade de armazenamento de chuva que, pode contribuir para a ocorrência destes processos, principalmente em eventos de precipitação intensa.

A amplitude pode indicar o potencial de deslocamento do material proveniente das encostas ou do próprio canal de drenagem. Para a bacia do Mococa houve uma variação entre 340 e $860 \mathrm{~m}$ e, para a bacia do Santo Antônio entre 10 e $810 \mathrm{~m}$. A sub-bacia 8 do rio Santo Antônio apresentou o menor valor de amplitude $(10 \mathrm{~m})$, indicando um baixo potencial de deslocamento destes sedimentos. As sub-bacias 2 e 5 (Santo Antônio) e 3 e 5 (Mococa) apresentaram valores superiores a 500 m, corroborando com os resultados obtidos por Jackson (1987), em que bacias com amplitudes superiores a $500 \mathrm{~m}$ e com áreas inferiores a $12 \mathrm{~km}^{2}$, apresentam maior probabilidade para a deflagração das corridas de detritos. Observou-se também que este comportamento não ocorreu em outras sub-bacias sob as mesmas condições, como as sub-bacias 9 (Santo Antônio), 4, 6, 7, 9, 13, 14 e 21 (Mococa).

Os resultados indicaram que as sub-bacias do rio Mococa apresentaram maior potencial em relação às da bacia do rio Santo Antônio. Ou seja, sub-bacias com uma resposta mais rápida, quando associadas a eventos de precipitação intensa, podem ser favorecidas pelo maior escoamento e aumento de sedimentos para os afluentes e canal principal. 
O comprimento total da rede de drenagem variou entre 2 e $50 \mathrm{~km} \mathrm{e} \mathrm{o}$ comprimento do rio principal entre 1 e $8 \mathrm{~km}$ para as sub-bacias do rio Santo Antônio. Para as sub-bacias do rio Mococa o comprimento total da rede de drenagem variou entre 0,5 e $16,7 \mathrm{~km}$ e o comprimento do rio principal entre 0,4 e 4,5 km.

Sabe-se que quanto maior for à extensão da drenagem, maior será 0 escoamento e maior será a probabilidade de transporte e de acúmulo de sedimentos em seu leito (IPT, 2002). Santi et al. (2008) observaram que os afluentes contribuíram com 54\% de sedimentos para o canal principal. Marston et al. (1997) afirmaram que, em eventos extremos, os sedimentos provenientes destas subbacias para o canal principal podem aumentar, apresentando variação no tamanho destes sedimentos que são incorporados no canal principal aumentando, assim, o impacto do processo.

Diferentemente das demais sub-bacias, onde houve a identificação destes processos e o seu deslocamento até o canal principal, esta situação não foi observada para a sub-bacia 3 (Mococa). Isto decorre devido a presença de rupturas ao longo do canal que podem favorecer a atenuação dos deslocamento da corrida de detritos.

Em relação às mensurações (zonas de deposição e arraste), as sub-bacias 1, 2 e 5 do rio Santo Antônio representaram 1,18 km, 0,91 km e 0,81km, respectivamente; e para as sub-bacias do Mococa $1,02 \mathrm{~km}$ (3) e 0,47 km (5). Isto significa que estes processos, em relação ao canal principal de cada sub-bacia, ocorreram entre $11 \%$ a $24 \%$ da extensão destes canais, indicando um alto volume de sedimentos para deslocamentos inferiores a $2 \mathrm{~km}$. Isso implica também, em uma maior agradação de sedimentos nestes canais, bem como, a exposição de antigos depósitos que podem servir como futuras áreas fontes. Além disso, tais depósitos servem de registros sobre a dinâmica destes processos nas bacias e sub-bacias da Serra do Mar.

As declividades médias dos canais das sub-bacias do Santo Antônio apresentaram valores de $5^{\circ}(1), 6^{\circ}$ (2) e $10^{\circ}(5)$, e para as sub-bacias do Mococa entre $9^{\circ}(3)$ e $10^{\circ}(5)$. No entanto, as sub-bacias $9,7,22,21,17,13,14$ e 33 (Mococa) são as mais propensas à remobilização e transporte, visto que, quanto 
maior a inclinação do canal, maior será a capacidade de retrabalhamento destes materiais (IPT, 2002; TIE, 2014).

Slaymaker (1990) observou que canais com ângulos entre $10^{\circ}$ e $25^{\circ}$ representaram zonas de transporte/erosão e os intervalos entre $5^{\circ}$ e $12^{\circ}$, zonas de deposição. Uma das causas da ocorrência destes processos nestes canais com baixos ângulos pode ser explicada pela densidade de drenagem destas sub-bacias, que somada à intensidade de precipitação, aumentaria a vazão de pico (descarga) destes canais e, assim, contribuiria para o deslocamento destes materiais, independente do seu tamanho, fato este comprovado por Day (1983).

Em relação ao índice de circularidade, os maiores valores estão associados às sub-bacias 7 e 9 (Santo Antônio) e 7, 13 e 22 (Mococa), indicando que teriam menor tempo de concentração favorecendo o escoamento mais rápido destas bacias, porém nenhuma ocorrência de corridas de detritos foi observada nestas subbacias. Como observado no capítulo anterior este parâmetro quando associado a eventos de grande intensidade de precipitação podem não responder de forma positiva na deflagração das corridas de detritos, mesmo quando apresentam outras características que apontem, que tais sub-bacias são suscetíveis a estes processos, por exemplo, a amplitude, o comprimento e a declividade do canal.

Christopher et al. (2010) e Sarma et al. (2013), estudando as bacias Onithsa (Nigégira) e Umtrew (Índia), respectivamente, observaram que bacias com valores inferiores a 0,5 apresentaram baixos valores de vazão, não favorecendo ao escoamento concentrado e rápido. No entanto, as sub-bacias aqui analisadas onde ocorreram as corridas de detritos, apresentaram índices entre 0,3 e 0,5 e com densidade de drenagem entre 3,5 e 4. Hajam et al. (2013) afirmaram que este parâmetro pode determinar o tempo de deslocamento do fluxo e, consequentemente o controle do escoamento da água e dos sedimentos. De fato, isso pode explicar a ocorrência destes processos nestas sub-bacias, que somado à intensidade de precipitação, contribuiria para a elevação destes rios, permitindo escoar todos os sedimentos, provenientes das encostas e, principalmente do próprio canal.

Acredita-se, portanto, que a escala de sub-bacia se mostra mais plausível na análise da ocorrência destes processos, sendo possível observar que a amplitude, e 
a densidade de drenagem explicariam a ocorrência destes processos. Ou seja, altas amplitudes e altos índices de densidade de drenagem, somado a precipitação intensa, podem explicar a ocorrência das corridas de detritos nestas sub-bacias.

5.5 Hierarquização das bacias: potencial de corridas de detritos 
Foram analisadas 40 sub-bacias quanto ao potencial de geração de corridas de detritos: Santo Antônio (8), Guaxinduba (20) e Mococa (12), conforme Apêndices III a V.

Em relação à vazão de pico, observou-se que quanto maior for o seu valor, maior será o volume de sedimentos do evento (Figuras 41 a 43). Esta condição refletiu com o aumento da precipitação, ou seja, com os valores adotados para os cenários (60 mm/h e $100 \mathrm{~mm} / \mathrm{h}$ ). Em outras palavras, o aumento da erosão do canal tende a aumentar com o aumento do escoamento superficial e, consequentemente tenderia a aumentar a vazão das corridas de detritos. Além disso, com o seu término, conduziria ao armazenamento, na recarga de sedimentos no leito do canal, podendo aumentar a magnitude em um evento futuro (RICKENMANN et al., 2003). Neste sentido, acredita-se que bacias com alto índice de densidade podem proporcionar uma maior vazão apresentando, assim, maior probabilidade de cheias e, consequentemente deslocar os materiais presentes no canal. 

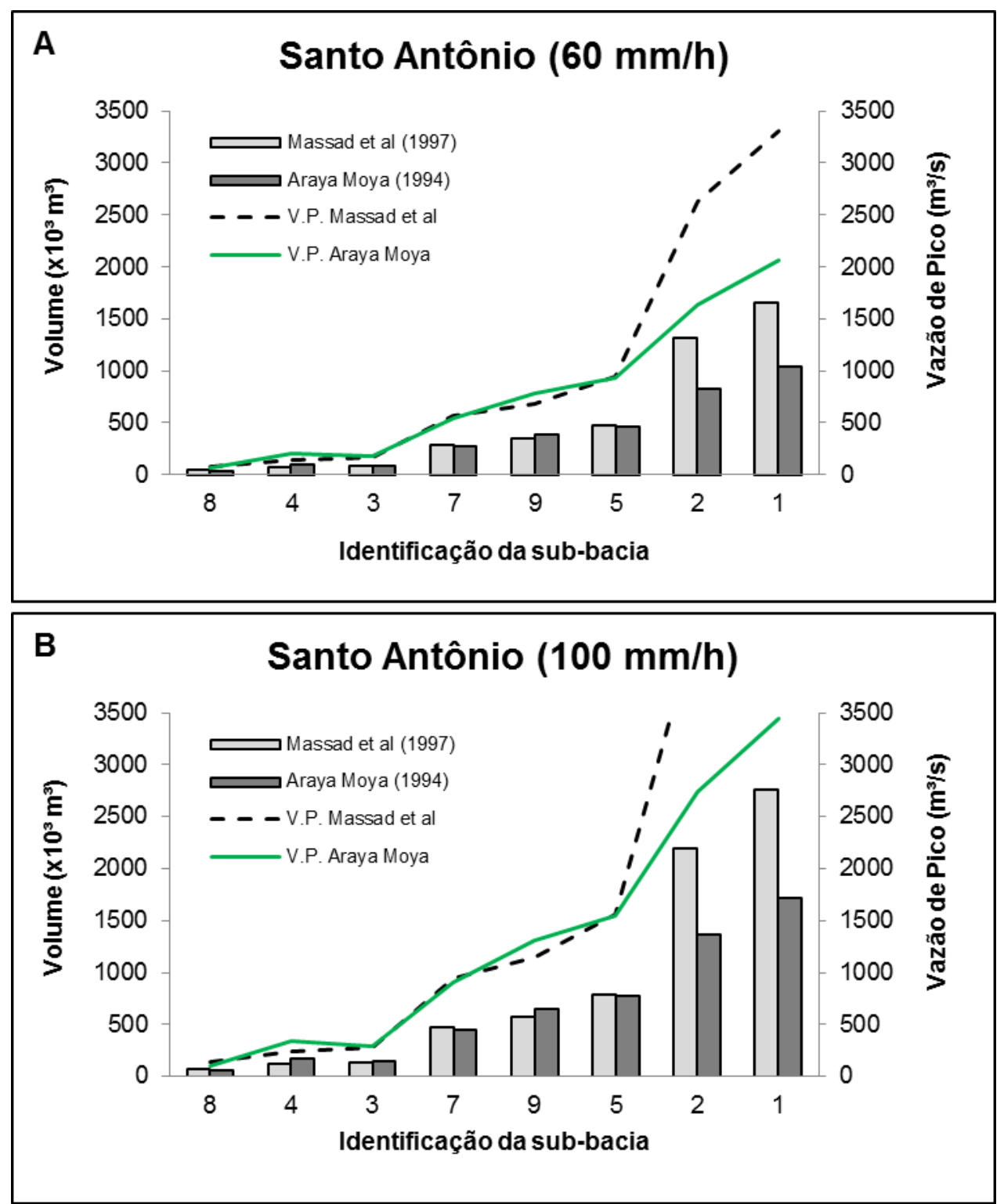

Figura 41: Gráfico de vazão de pico em função do volume de sedimentos para os cenários de 60 $\mathrm{mm} / \mathrm{h}$ (a) e $100 \mathrm{~mm} / \mathrm{h}$ (b). Observou-se que com o aumento da área da bacia há o aumento da vazão de pico e consequentemente, o aumento do volume de sedimentos para as sub-bacias do rio Santo Antônio. 

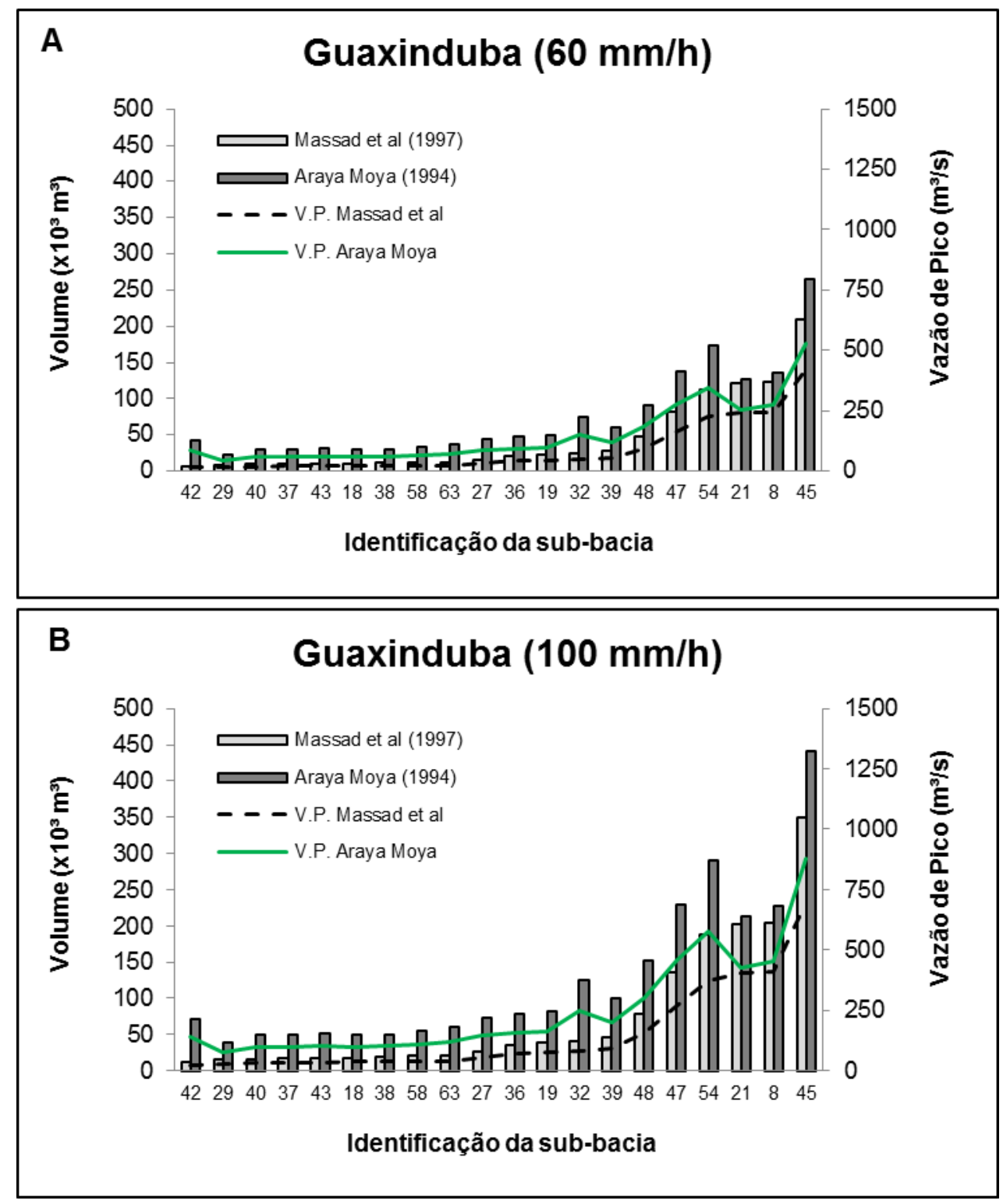

Figura 42: Gráfico de vazão de pico em função do volume de sedimentos para os cenários de 60 $\mathrm{mm} / \mathrm{h}$ (a) e $100 \mathrm{~mm} / \mathrm{h}$ (b). Observou-se que com o aumento da área da bacia há o aumento da vazão de pico e consequentemente, o aumento do volume de sedimentos para as sub-bacias do rio Guaxinduba. 

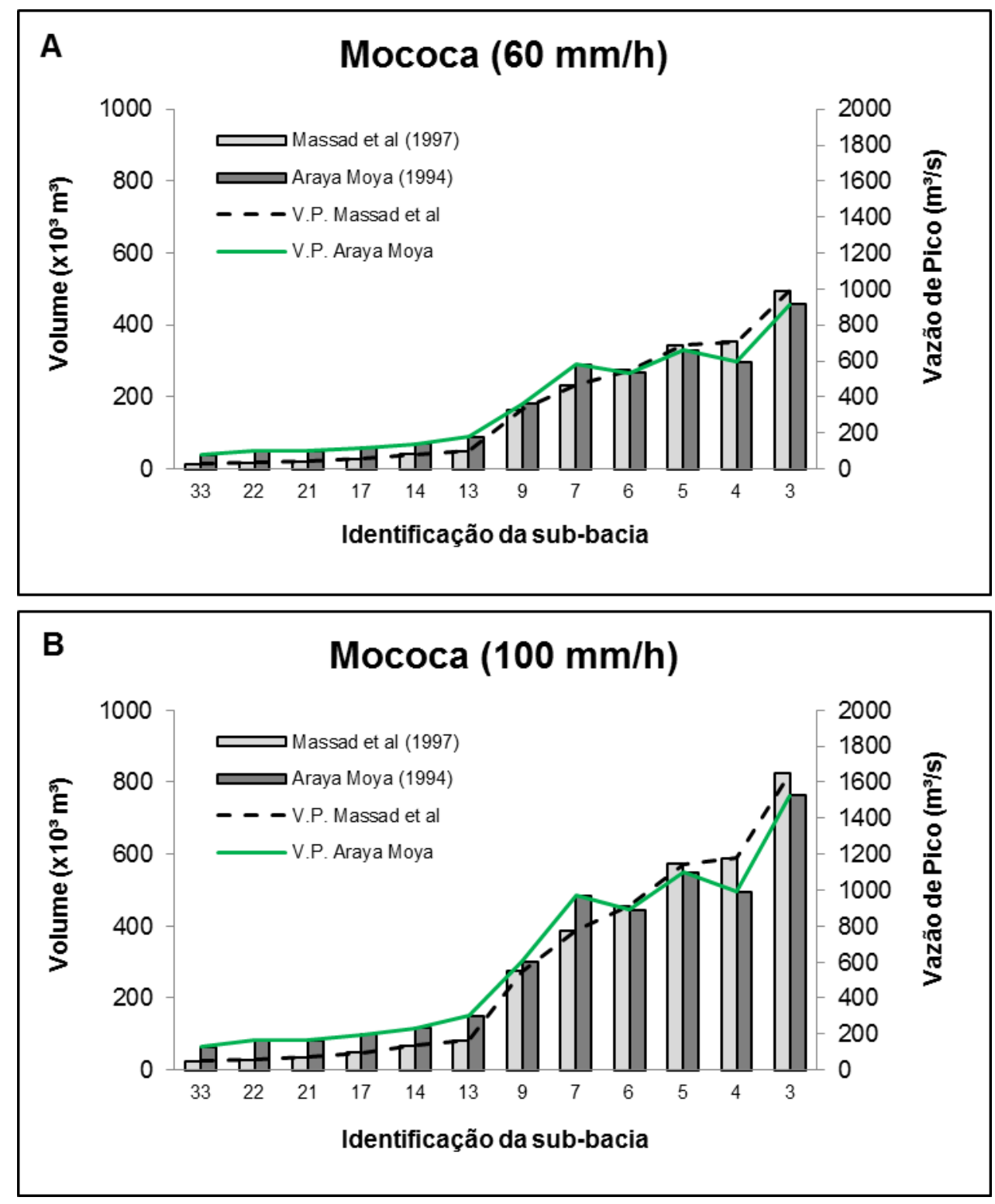

Figura 43: Gráfico de vazão de pico em função do volume de sedimentos para os cenários de 60 $\mathrm{mm} / \mathrm{h}$ (a) e $100 \mathrm{~mm} / \mathrm{h}$ (b). Observou-se que com o aumento da área da bacia há o aumento da vazão de pico e consequentemente, o aumento do volume de sedimentos para as sub-bacias do rio Mococa.

$\mathrm{Na}$ literatura casos relacionados às intensidades de precipitação e de vazões de pico são observados em diferentes regiões do mundo. Aqui se verificou que a intensidade de precipitação e a ordem de grandeza das sub-bacias influenciaram nos valores de vazão de pico das corridas de detritos.

A vazão de pico para ambas as formulações em relação ao cenário de 60 $\mathrm{mm} / \mathrm{h}$, para as sub-bacias com áreas inferiores $0,30 \mathrm{~km}^{2}$, geraram valores entre $14 \mathrm{e}$ 
$92 \mathrm{~m} 3 / \mathrm{s}$ para as sub-bacias do rio Guaxinduba $(42,29,40,37,46,18,38,58,63,27$, 36, 19, 32 e 39) (Figura 44); e entre 29 e $119 \mathrm{~m}^{3} / \mathrm{s}$ para as sub-bacias do rio Mococa $(33,22,21$ e 17) (ver figura 40, pág. 107). Valores de vazão de pico próximos a estes para uma bacia com área de $0,30 \mathrm{~km}^{2}$ foram encontrados por Berti et al. (1999), nos Alpes italianos, decorrentes de uma intensidade de 25 mm em 35 min que ocasionou uma corrida de detritos com vazão entre 23 e $71 \mathrm{~m}^{3} / \mathrm{s}$. Mesmo que bacias inferiores a $0,30 \mathrm{~km}^{2}$ tendem a apresentarem um menor escoamento estas podem ser capazes de transportar volumes de sedimentos significativos. Além disso, mesmo que estas áreas apresentem menores vazões, estes sedimentos podem alcançar mais rapidamente o canal principal destas bacias permitindo o barramento do canal e/ou potencializando o deslocamento destes sedimentos neste canal.
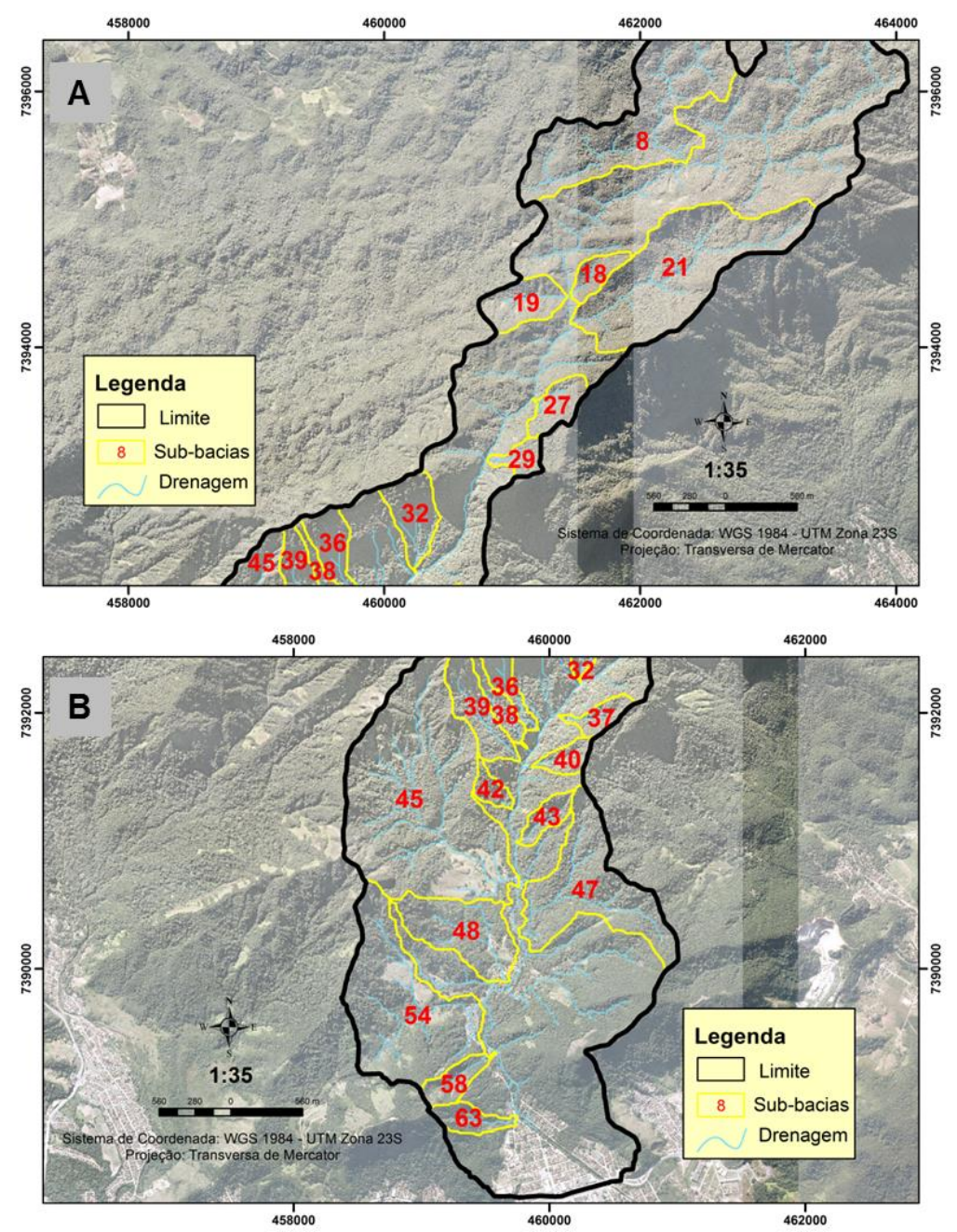

Figura 44: Localização e identificação das sub-bacias do rio Guaxinduba, destacando as sub-bacias com áreas inferiores a $0,30 \mathrm{~km}^{2}(42,29,40,37,46,18,38,58,63,27,36,19,32$ e 39) e que geraram baixos valores de vazão de pico. 
Hurlimann et al. (2003) para 4 eventos de corridas de detritos ocorridas nas bacias Schipfenbach $\left(1,80 \mathrm{~km}^{2}\right)$ e Illbach $\left(10,5 \mathrm{~km}^{2}\right)$, Alpes suíços, após precipitação de $56 \mathrm{~mm} / \mathrm{h}$, encontraram a vazão de pico entre 70 e $125 \mathrm{~m} / \mathrm{s}$, respectivamente. Os valores encontrados por estes autores associam-se aos dados obtidos para 0 cenário de $60 \mathrm{~mm}$ e para sub-bacias com áreas inferiores a $0,40 \mathrm{~km}^{2}$. Estes valores de vazão, como observado anteriormente, produzem menores volumes de sedimentos, podendo indicar que houve pouca erosão do canal e/ou até mesmo a não contribuição de escorregamentos que contribuíssem para o aumento deste volume, fato este confirmado pelos autores.

Kanji et al. (2008) observaram na bacia do rio das Pedras (2,64 km²), Cubatão (SP), valores de vazão de pico entre 630 e $780 \mathrm{~m}^{3} / \mathrm{s}$ para uma precipitação de 60 $\mathrm{mm} / \mathrm{h}$. Estes valores foram similares aos resultados para as sub-bacias com áreas entre 2 e 3 km², (ex. sub-bacias 9 do rio Santo Antônio; 5 e 4 do rio Mococa): 590 e $782 \mathrm{~m}^{3} / \mathrm{s}$, respectivamente.

A vazão de pico destas bacias e o volume de sedimentos gerados assemelham-se aos valores obtidos para o evento que paralisou a refinaria Presidente Bernardes, em Cubatão no ano 1994, com $300.000 \mathrm{~m}^{3}$ (KANJl et al., 2003). Estes valores de vazão e de volume de sedimentos podem causar danos, como os apontados acima.

Sub-bacias com áreas superiores a $10 \mathrm{~km}^{2}$ (encontradas na bacia do rio Santo Antônio) geraram vazão de pico superiores a $1.640 \mathrm{~m} 3 / \mathrm{s}$ para o cenário de 60 $\mathrm{mm} / \mathrm{h}$, diferente daqueles obtidos por Tang et al. (2011), que observaram precipitação de $77,3 \mathrm{~mm} / \mathrm{h}$ sobre duas bacias com áreas de $25,75 \mathrm{~km}^{2}$ e $16,14 \mathrm{~km}^{2}$, em que as corridas de detritos apresentaram vazão de pico entre 1.358 e 572 m³/s, respectivamente. Mesmo apresentando áreas inferiores a estas duas bacias, acredita-se que as sub-bacias aqui analisadas contribuíram de forma mais significativa no escoamento destes processos, gerando maiores volumes de sedimentos. Por mais que os valores fossem estimados, pode ter ocorrido um maior retrabalhamento destes materiais, fato este observado na fotointerpretação destes processos nas sub-bacias em questão e comprovados por Cruz (1974) e Fúlfaro et 
al. (1976), que identificaram grande quantidade de material remobilizado para o evento de 1967.

Observou-se, em relação ao cenário de $100 \mathrm{~mm} / \mathrm{h}$, que os valores de vazão representaram $60 \%$ a mais em relação ao cenário de $60 \mathrm{~mm} / \mathrm{h}$. Este acréscimo implicou em um maior escoamento de sedimentos nestas sub-bacias e bacias e, consequentemente aumentaram a possibilidade de causar maiores impactos. Como observado na literatura, por mais que a intensidade de precipitação seja importante na ocorrência das corridas de detritos (Hurlimann et al., 2003; Gramani, 2013) a precipitação acumulada apresenta-se como fundamental na deflagração destes processos (KOBIYAMA et al., 2010).

Observações a respeito da importância da precipitação em relação à vazão dos rios foram realizadas por Perucca e Angilieri (2001) em estudos na bacia Del Molle, Argentina, em condições não saturadas e de pré-saturação do solo. Por meio da modelagem matemática, observaram para um cenário de $52 \mathrm{~mm} / \mathrm{h}$ os valores de vazão entre 269,4 e 962,8 m³/s para ambas as condições e, para o cenário de 40 $\mathrm{mm} / \mathrm{h}$, entre 111,8 e $621,7 \mathrm{~m} 3 / \mathrm{s}$, respectivamente. Tais considerações, somada às características da bacia permitem afirmar que a intensidade de precipitação, assim como a precipitação acumulada, tem papel fundamental no escoamento destes fluxos, principalmente nos deslocamentos destes sedimentos.

Portanto, acredita-se que os eventos aqui analisados foram decorrentes dos 5 meses de precipitação entre os anos de 1966 e 1967 no litoral norte do estado, principalmente no município de Caraguatatuba. Consequentemente, nesta situação pode-se considerar que todos os solos das sub-bacias se encontravam em estado de pré-saturação e/ou totalmente saturados, contribuindo definitivamente para a deflagração e para a ocorrência destes processos.

Assumindo estas condições, os valores mínimos e máximos obtidos para uma precipitação de $60 \mathrm{~mm} / \mathrm{h}$ na bacia do Santo Antônio, para ambas as formulações, gerou vazões de pico na ordem de 83,18 e 65,05 m³/s e 3.312 e 2.067 m³. Nesta mesma condição, mínimos e máximos, para a bacia do Guaxinduba, os valores foram 14,67 e $85,86 \mathrm{~m}^{3} / \mathrm{s}$ e 418,82 e $528,85 \mathrm{~m}^{3} / \mathrm{s}$, respectivamente. Em relação à 
bacia do Mococa, estes valores, mínimos e máximos, variaram entre 29,30 e 77,89 $\mathrm{m}^{3} / \mathrm{s}$ e 989,47 e $915,54 \mathrm{~m}^{3} / \mathrm{s}$, respectivamente.

Analisando o cenário de $100 \mathrm{~mm} / \mathrm{h}$, os valores mínimos e máximos, em relação à vazão de pico, para a bacia do Santo Antônio representam 139 e 108 m³/s e, 5.521 e $3.446 \mathrm{~m}^{3} / \mathrm{s}$; para a bacia do Guaxinduba representaram 24,45 e $143 \mathrm{~m} 3 / \mathrm{s}$ e, 698 e 881 m³/s e; para a bacia do Mococa foram de 49 e $130 \mathrm{~m}^{3} / \mathrm{s}$ e, 1.649 e $1.525 \mathrm{~m}^{3} / \mathrm{s}$, respectivamente. Mesmo que decorrentes de precipitações heterogêneas nestas bacias, cada sub-bacia apresentou comportamento diferenciado, mas no conjunto os processos ocorridos em cada uma delas permitiram elucidar a magnitude (volume de sedimentos) do evento nestas bacias. Além disso, foi possível verificar que sub-bacias com maiores amplitude e comprimento de canal geraram maiores valores de vazão de pico e, portanto, maiores volumes de sedimentos. Tal análise corrobora os pressupostos de Jackson (1987), o qual afirma que bacias com amplitudes superiores a $500 \mathrm{~m}$ tendem apresentar maior potencial energético para transportar estes sedimentos.

Os parâmetros morfométricos utilizados apresentaram resultados distintos entre as sub-bacias. Observou-se que as áreas superiores a $3 \mathrm{~km}^{2}$ foram mais significativas, com maiores volumes de sedimentos, podendo aumentar o potencial de geração de corridas, como verificado para as bacias dos rios Santo Antônio e Mococa (Figuras 45 e 47). Inversamente, sub-bacias com áreas inferiores a $1 \mathrm{~km}^{2}$ tendem a produzir menos sedimentos, como observado na bacia do Guaxinduba (Figura 46). No entanto, acredita-se que sub-bacias com ordem de grandeza inferior a $1 \mathrm{~km}^{2}$ e grandes amplitudes podem contribuir de forma mais significativa, devido ao escoamento mais rápido destes sedimentos ao longo da rede de drenagem.

Observou-se que sub-bacias com áreas inferiores a $1 \mathrm{~km}^{2}$ para o cenário de $60 \mathrm{~mm} / \mathrm{h}$, geraram volumes máximos próximos a $120 \mathrm{mil} \mathrm{m}^{3}$, em relação ao cenário de $100 \mathrm{~mm} / \mathrm{h}$, foram próximos a $190 \mathrm{mil} \mathrm{m³}$.

Sub-bacias com até $3 \mathrm{~km}^{3}$ para o cenário de $60 \mathrm{~mm} / \mathrm{h}$, geraram volumes máximos na ordem de $350 \mathrm{mil} \mathrm{m}^{3} \mathrm{e}$, de $590 \mathrm{mil} \mathrm{m}^{3}$ para o cenário de $100 \mathrm{~mm} / \mathrm{h}$. Áreas superiores a $3 \mathrm{~km}^{2}$ geraram volumes superiores a $450 \mathrm{mil} \mathrm{m}^{3}$, com valores 
máximos de 1,7 milhão para o cenário de $60 \mathrm{~mm} / \mathrm{h}$ e, para o cenário de $100 \mathrm{~mm} / \mathrm{h}$ acima 770 mil até 2,7 milhões de $\mathrm{m}^{3}$ (Figuras 42 a 44).

Nos cenários propostos (60 a $100 \mathrm{~mm} / \mathrm{h}$ ) houve um aumento de $60 \%$ do volume total de sedimentos, para ambos os modelos empregados, Araya Moya (1994) modificada e Massad et al., (1997). Esta situação também foi observada por Gartner et al. (2008) para as corridas de detritos no oeste dos Estados Unidos, onde observaram que a precipitação total do evento teve grande influência sobre o volume gerado por estes processos.
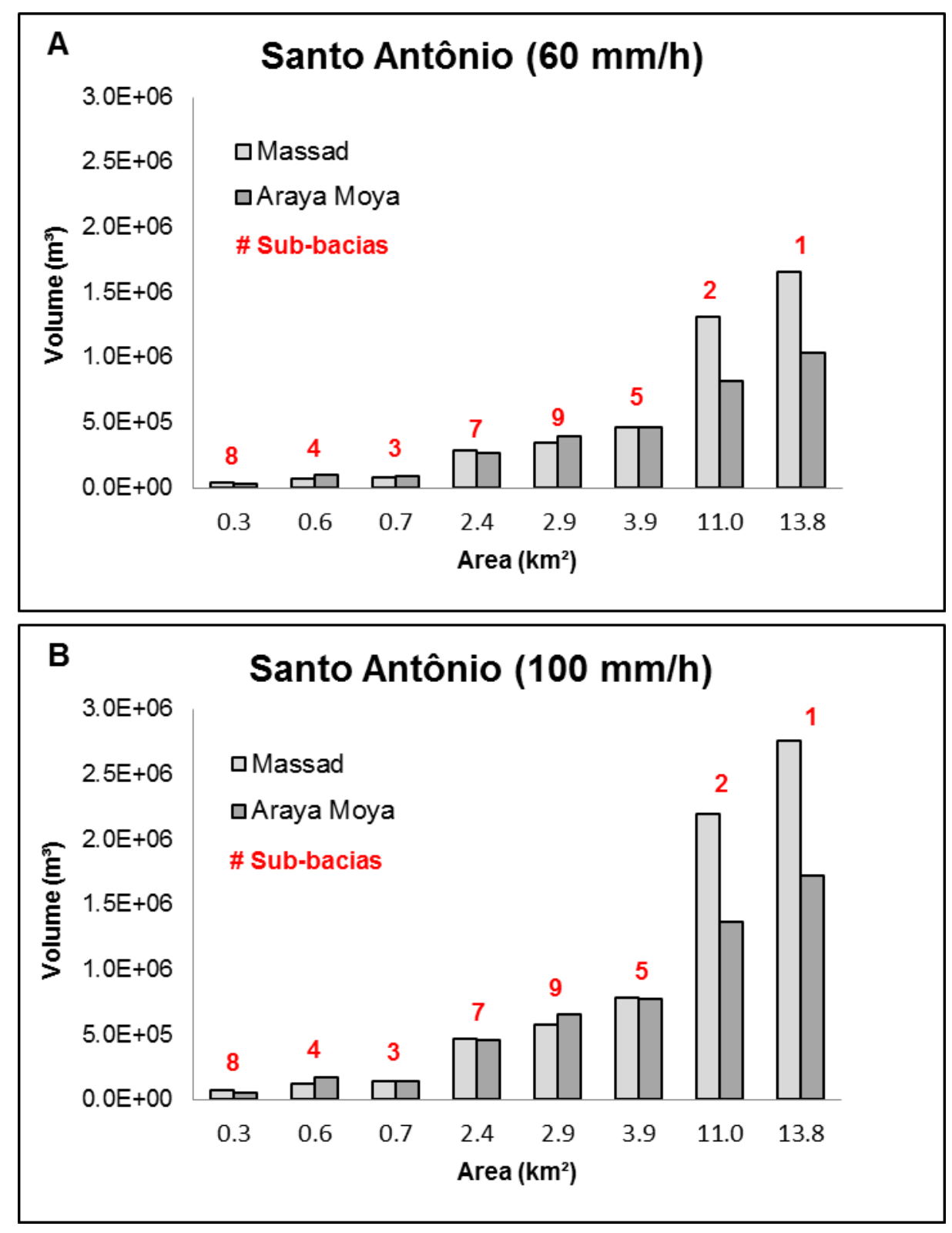

Figura 45: Gráfico de volume total de sedimentos. Observa-se que há uma tendência de aumento do volume em função da área da bacia. Entre os cenários (a) e (b) este aumento de volume foi de $60 \%$. 

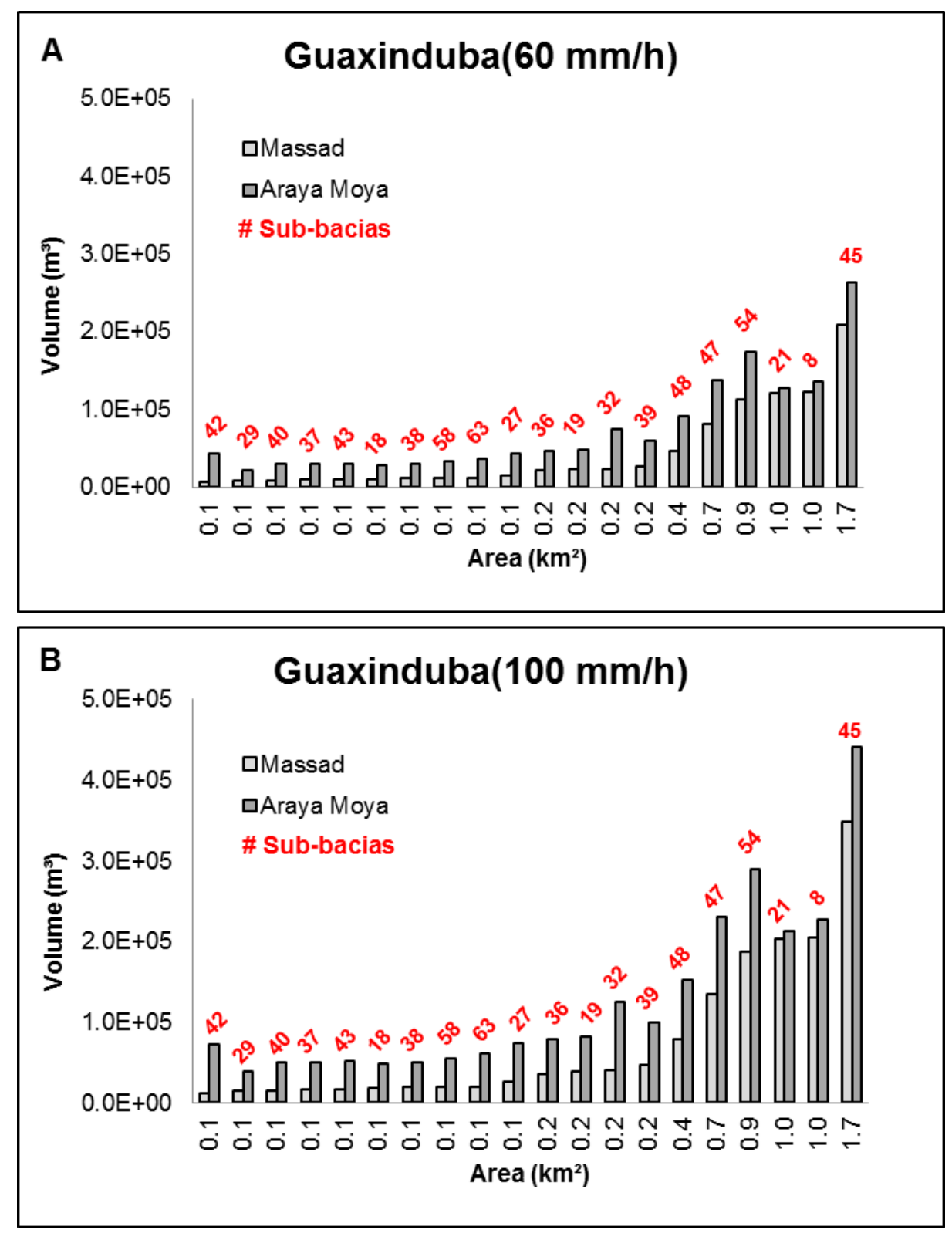

Figura 46: Gráfico de volume total de sedimentos. Observa-se que áreas inferiores a $1 \mathrm{~km}^{2}$ apresentaram comportamento similar para ambos os cenários (a) e (b). O modelo de Araya Moya (1994) apresentou-se mais sensível para esta bacia, podendo indicar maior influência da amplitude nestas sub-bacias. 

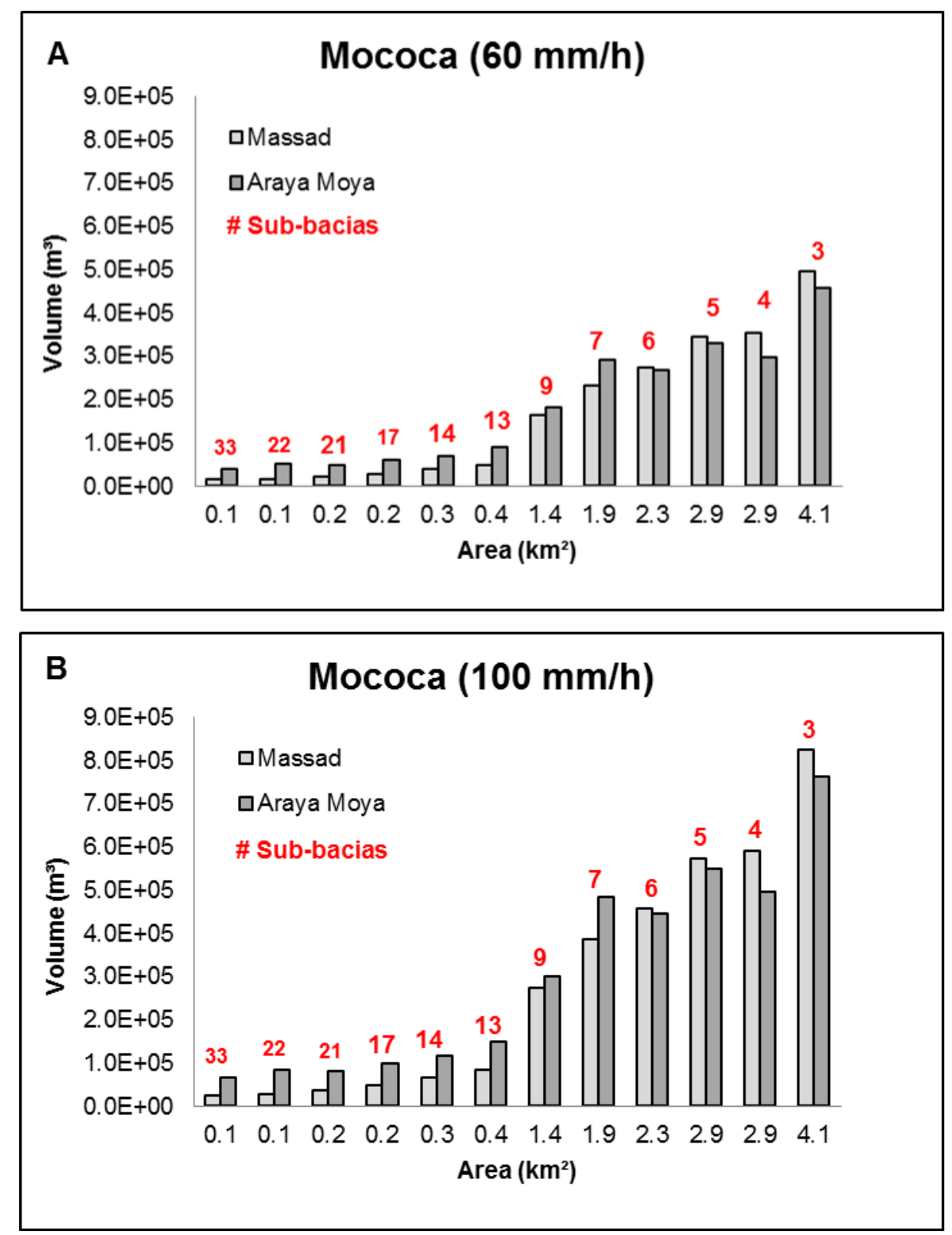

Figura 47: Gráfico de volume total de sedimentos. Observa-se comportamento distinto, em ambos os cenários (a) e (b), em relação aos modelos adotados. Para sub-bacias entre 0,1 a 1,9 km o modelo de Araya Moya (1994) foi mais sensível; enquanto para sub-bacias entre 2,3 a 4,1 km² o modelo mais sensível foi o de Massad et al. (1997).

Comparando os volumes de sedimentos para as sub-bacias de menor e maior área para a bacia do Santo Antônio, em relação ao cenário de $60 \mathrm{~mm} / \mathrm{h}$, os seguintes valores foram obtidos (considerando ambos os modelos): entre $41.591 \mathrm{e}$ $32.528 \mathrm{~m}^{3}$ (área de 0,35 km²) e 1.656,303 e 1.033,689 m³ (área de 13,8 km²). Em relação ao cenário de $100 \mathrm{~mm} / \mathrm{h}$, estes valores representaram: 69.319 e $54.213 \mathrm{~m}^{3}$ (área de 0,35 km²); e 2.760,505 e 1.722,815 m³ (área de 13 km²) (Figura 45). 
A bacia do Guaxinduba apresentou uma maior concentração de sub-bacias com áreas inferiores a $1 \mathrm{~km}^{2}$, com uma forte influência da amplitude e do comprimento do canal que variou entre 60 e $720 \mathrm{~m}$ e 0,12 e 2,35 km, respectivamente, para ambos os cenários.

O volume para a menor área desta bacia resultou em valores 2 a 6 vezes inferiores para o modelo de Massad et al. (1997) em relação ao modelo de Araya Moya (1994). No entanto, para as sub-bacias com áreas de $1 \mathrm{~km}^{2}$ o volume de sedimentos não apresentou o mesmo comportamento, com valores próximos para ambas formulações (Figura 46).

A diferença entre os volumes de sedimentos para áreas inferiores a $1 \mathrm{~km}^{2}$ também foi observada para a bacia do rio Mococa (Figura 47), contudo, a variação foi menor em relação à bacia do rio Guaxinduba. Os volumes para a menor e a maior área (cenário de $60 \mathrm{~mm} / \mathrm{h}$ ) foram de 14.652 e $38.946 \mathrm{~m}^{3}$ e 494.733 e 457.768 , respectivamente. Em relação a estas mesmas áreas, para o cenário de $100 \mathrm{~mm}$, os valores de volume foram 24.420 e $64.911 \mathrm{~m}^{3}$ e 824.555 e $762.948 \mathrm{~m}^{3}$, respectivamente.

Rickenmann e Zimmermann (1993) estudaram as corridas de detritos no Vale Varuna, Alpes, em 1987, e verificaram que os volumes de sedimentos foram na ordem de 100 a $100.000 \mathrm{~m}^{3}$, em uma área $5 \mathrm{~km}^{3}$. Em comparação com as subbacias 5 (Santo Antônio) e 3 (Mococa), ambas com aproximadamente 4 km², os volumes de sedimentos foram superiores a $400.000 \mathrm{~m}^{3}$.

Como observado à magnitude do evento pode estar associada à disponibilidade de sedimentos, tanto na encosta quanto no canal (RICKENMANN e ZIMMERMANN, 1993). Analisando a sub-bacia 3 (Mococa), área com corridas de detritos, acredita-se que a maior contribuição de sedimentos foi decorrente do próprio canal, pois os escorregamentos contribuíram com apenas com $12.496 \mathrm{~m}^{3}$.

IPT (2002) simulou dois cenários para obter volumes de sedimentos para três sub-bacias do Rio Grande em Ubatuba (SP). Para uma sub-bacia com área de 1,9 $\mathrm{km}^{2}$, os volumes de sedimentos observados variaram, para o cenário de $60 \mathrm{~mm} / \mathrm{h}$, entre 114.233 e $190.388 \mathrm{~m}^{3}$; e para o cenário de $100 \mathrm{~mm} / \mathrm{h}$, entre 111.199 e 185.332 $\mathrm{m}^{3}$. As sub-bacias 45 (bacia do Guaxinduba) e 7 (bacia do Mococa), com áreas 
similares, registraram o dobro de volume para os mesmos cenários. Mesmo utilizando os mesmos modelos empíricos, os resultados apresentam-se distintos e estes podem estar relacionados à entrada de dados nestas equações.

Melelli e Taramelli (2004) analisaram 11 sub-bacias, na Itália, com áreas entre 1 e $3 \mathrm{~km}^{2}$ e os volumes de sedimentos obtidos variaram entre 2.000,000 a $32.000 .000 \mathrm{~m}^{3}$, contribuindo com $64 \%$ do volume. Comparando com as sub-bacias da mesma ordem de grandeza, para ambos os cenários, as sub-bacias do Santo Antônio contribuíram entre 14\% e 21\%, Guaxinduba, entre 50\% e 35\% e Mococa entre $67 \%$ e $62 \%$. Estes resultados indicaram que para uma precipitação de 60 $\mathrm{mm} / \mathrm{h}$ as sub-bacias do Guaxinduba e Mococa contribuíram com um maior volume de sedimentos. Para o cenário de $100 \mathrm{~mm} / \mathrm{h}$ apenas a bacia do Mococa apresentou condições de produção de sedimentos para tais sub-bacias.

Avaliando os principais eventos de corrida de detritos entre 1976 e 1996 nas bacias e sub-bacias próximas ao Pólo Industrial de Cubatão, Kanji et al. (2008) estimaram o volume de sedimentos e observaram que, para as bacias e sub-bacias entre 0,80 e $4 \mathrm{~km}^{2}$ de área, o volume variou entre 14.000 a $158.000 \mathrm{~m}^{3}$. Verificou-se que os valores obtidos para estas áreas foram inferiores quando comparadas com as sub-bacias similares em área: 3 e 5 (Santo Antônio), 54 (Guaxinduba) e 3 (Mococa). Observa-se que, os resultados obtidos para estas sub-bacias foram 6 a 8 vezes maiores para áreas similares a $0,80 \mathrm{~km}^{2}$ e 3 vezes a mais para áreas similares a $4 \mathrm{~km}^{2}$, em relação aos valores obtidos por Kanji et al. (2008). Esta diferença nos resultados, mesmo empregando os mesmos modelos empíricos, decorreu do emprego de valores distintos de intensidade de precipitação, uma vez que estes autores utilizaram índices de $18 \mathrm{~mm} / \mathrm{h}$ e $39 \mathrm{~mm} / \mathrm{h}$ (ao invés de $60 \mathrm{~mm} / \mathrm{h}$, como utilizado neste estudo) gerando um menor valor de sedimentos paras estas bacias e sub-bacias.

Portilla et al. (2010) estudaram as corridas de detritos no Pirineus (Espanha), mensurando o volume para o ano de 2008, que variou entre 1.000 a $26.000 \mathrm{~m}^{3}$ para bacias com áreas entre 0,2 a $8,2 \mathrm{~km}^{2}$. Os autores observaram que a magnitude do evento foi proporcional ao aumento da área da bacia, como também verificado por D’Agostino e Marchi (2001), nos Alpes italianos. Realmente, esta suposição mostra- 
se coerente, visto que, o volume de sedimentos, em ambos os cenários, apresentou esta tendência para todas sub-bacias analisadas neste trabalho, em relação à fórmula empírica de Massad et al. (1997).

Chen e Chuang (2014), estudando as corridas de detritos no sudeste de Taiwan, observaram volumes entre 50.000 e $100.000 \mathrm{~m}^{3}$ (sub-bacia com área de 0,083 km²), 800.000 e 1.100,000 m³ (sub-bacia com área de 0,297 km²) e 600 e $10.000,000 \mathrm{~m}^{3}$ (sub-bacia com área de 0,341 km²). O volume de sedimentos gerado por estas sub-bacias foi decorrente de uma precipitação de $103 \mathrm{~mm} / \mathrm{h}$ e de 1200 $\mathrm{mm} / 24 \mathrm{~h}$. Tal condição era esperada para um tempo de retorno acima de 200 anos. O maior volume de sedimentos observado para as sub-bacias analisadas foi de $2.760,505 \mathrm{~m}^{3}$, associado ao cenário de $100 \mathrm{~mm} / \mathrm{h}$ (tempo de retorno para 100 anos).

Em relação às sub-bacias onde foram identificadas zonas de deposição e de arraste, sub-bacias 1, 2 e 5 (Santo Antônio) e 3 e 5 (Mococa) (Figura 48), pode-se correlacionar os volumes de sedimentos provenientes das cicatrizes e das zonas de deposição e de arraste em relação aos volumes obtidos pelos modelos empíricos.

Quanto a bacia do Santo Antônio, o volume de sedimentos da zona de deposição e de arraste para a sub-bacia 1 foi de 171,558 $\mathrm{m}^{3}$ e, quando comparado com as formulações para o cenário de $60 \mathrm{~mm} / \mathrm{h}$, estes volumes representaram cerca de $10 \%\left(1.656,303 \mathrm{~m}^{3}\right)$ e $16 \%\left(1.033,689 \mathrm{~m}^{3}\right)$. Para o cenário de $100 \mathrm{~mm}$ estes volumes representaram $6 \%\left(2.760,505 \mathrm{~m}^{3}\right)$ e $10 \%\left(1.722,815 \mathrm{~m}^{3}\right)$.

Estes volumes para a sub-bacia $2\left(275.941 \mathrm{~m}^{3}\right)$ representaram para o cenário de $60 \mathrm{~mm} / \mathrm{h} 21 \%\left(1.317,273 \mathrm{~m}^{3}\right)$ e $34 \%\left(820.803 \mathrm{~m}^{3}\right)$; e para o cenário de $100 \mathrm{~mm} / \mathrm{h}$, representaram 13\% $\left(2.195,456 \mathrm{~m}^{3}\right)$ e $20 \%\left(1.368,005 \mathrm{~m}^{3}\right)$. Para a sub-bacia 5 $\left(138,503 \mathrm{~m}^{3}\right)$ estes volumes representaram 30\% (469.377 e $\left.452.747 \mathrm{~m}^{3}\right)$, para o cenário de $60 \mathrm{~mm}$; e 18\% (782.295 e $\left.771.245 \mathrm{~m}^{3}\right)$, para o cenário de $100 \mathrm{~mm}$.

Quanto a bacia do Mococa, estes volumes de sedimentos, para o cenário de $60 \mathrm{~mm} / \mathrm{h}$, representaram 15\% (494.733 m³) e 16\% (457.769 m³); e para o cenário de $100 \mathrm{~mm} / \mathrm{h}$, representaram $9 \%\left(824.555 \mathrm{~m}^{3}\right)$ e $10 \%\left(762.948 \mathrm{~m}^{3}\right)$, em relação à subbacia $3\left(76.757 \mathrm{~m}^{3}\right)$. Estes volumes de sedimentos para a sub-bacia $5\left(68.483 \mathrm{~m}^{3}\right)$, em relação ao cenário de $60 \mathrm{~mm} / \mathrm{h}$, representou 20\% (343.772) e 21\% (329.265 m³); e $12 \%\left(572.954 \mathrm{~m}^{3}\right)$ e $12 \%\left(548.775 \mathrm{~m}^{3}\right)$, para o cenário de $100 \mathrm{~mm} / \mathrm{h}$. 


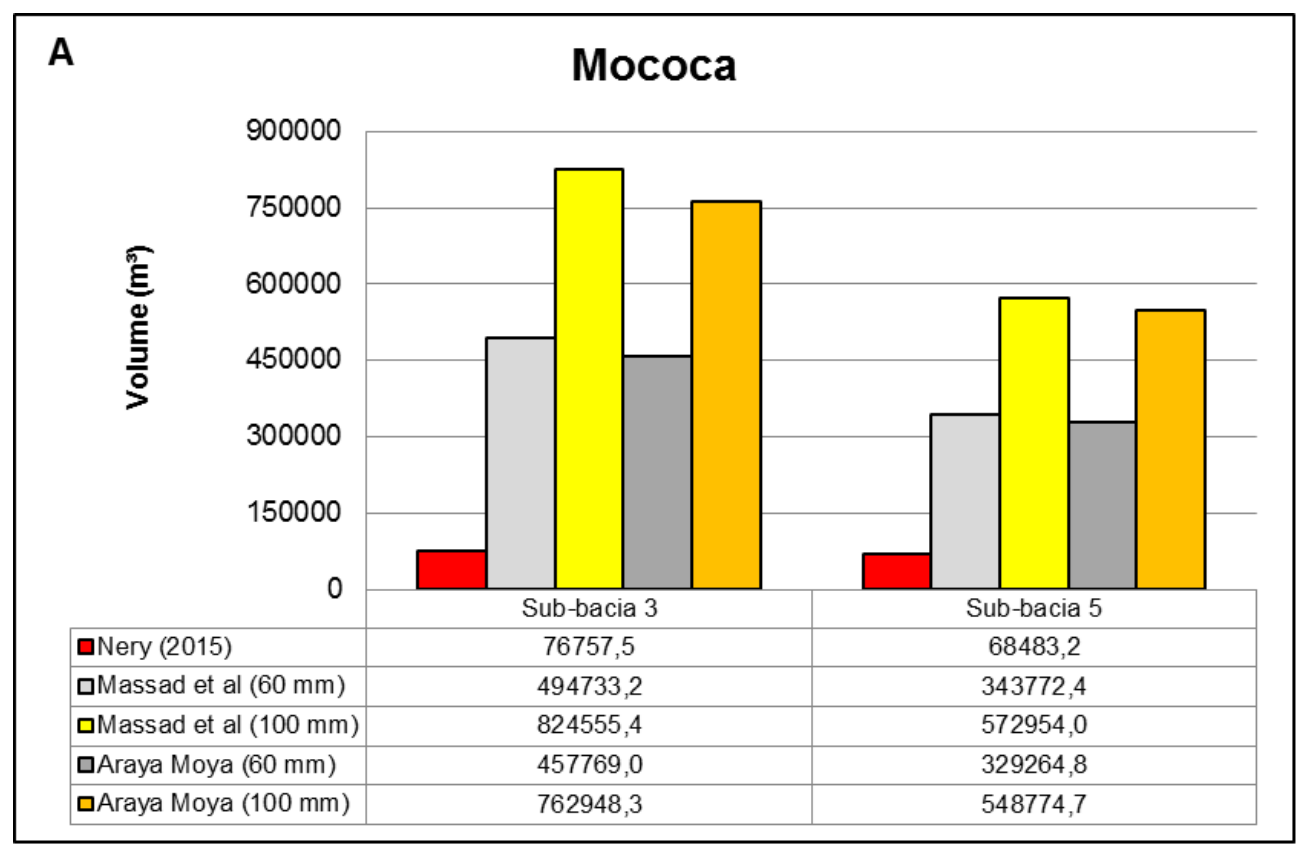

B

Santo Antônio

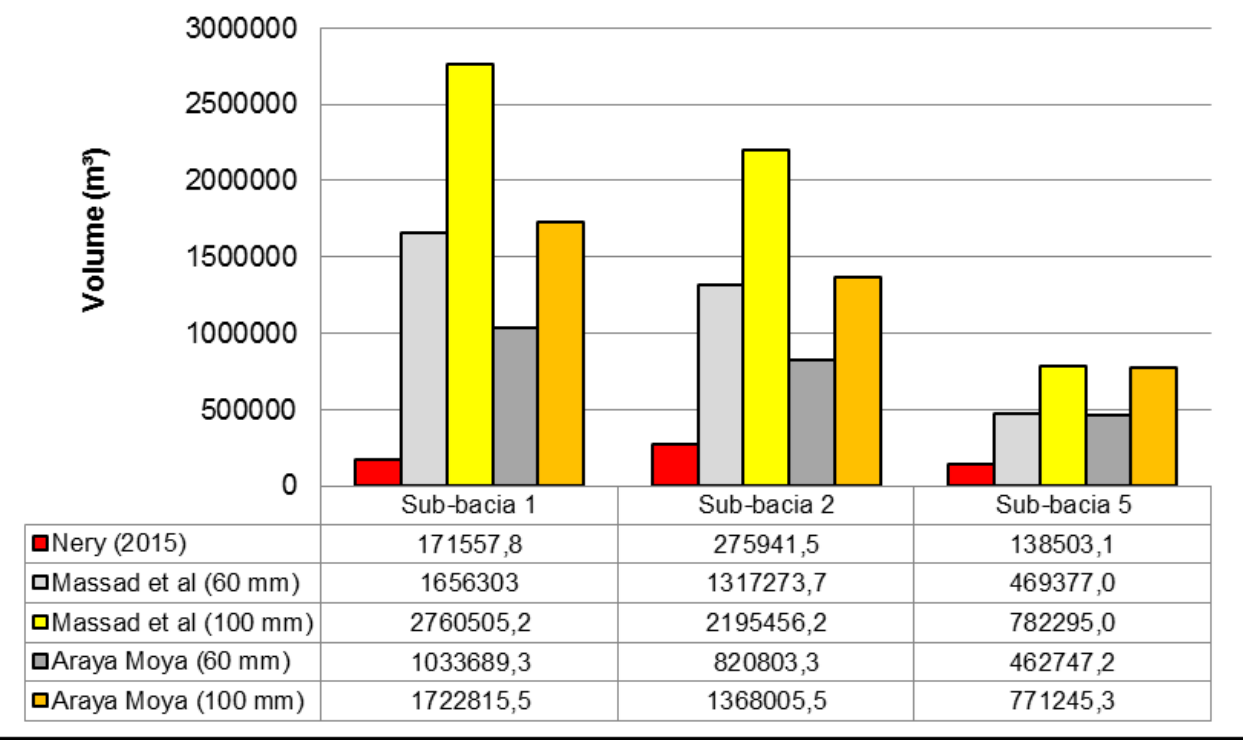

Figura 48: Gráfico de volume de sedimentos (cicatrizes e depósitos) em função dos modelos empíricos para bacias do Mococa (a) e Santo Antônio (b). Os resultados obtidos mostraram por meio das cicatrizes e depósitos que estes representaram até $30 \%$ do volume gerado quando comparados com as formulações.

A partir destes dados, observou-se que os sedimentos provenientes dos escorregamentos e das zonas de deposição e de arraste foram inferiores quando comparados aos modelos empíricos de Araya Moya (1994) e Massad et al. (1997).

Acredita-se, que esta diferenciação de valores possa ter sido decorrente do método de mapeamento das cicatrizes dos escorregamentos empregado na 
identificação destes processos. Ou seja, assumiu-se neste trabalho um único valor de espessura de ruptura $(0,5 \mathrm{~m})$, não diferenciando os diferentes escorregamentos na bacia. Entretanto, mesmo assumindo apenas a área de ruptura destes processos, estes valores ainda seriam inferiores.

Além disso, esta diferenciação entre estes valores de volumes de sedimentos também pode ter decorrido devido as características dos modelos empíricos aplicados. Observou-se que o emprego de diferentes métodos para estimar a vazão de pico e o volume pode induzir a superestimação destes, como também observado por Wrachien e Mambretti (2001). Estes valores superestimados dos modelos empíricos utilizados aqui podem ser decorrentes, por exemplo, do valor de concentração de sólidos e da intensidade de precipitação, ou até mesmo sobre os parâmetros morfométricos adotados por tais modelos. Quando comparadas às pesquisas aqui apresentadas, um exemplo desta situação ficou evidenciada nos estudos realizados pelo IPT (2002) e por Kanji et al. (2008) que aplicaram os mesmos modelos para a Serra do Mar e obtiveram resultados 2 a 6 vezes menores do que os resultados apresentados neste trabalho.

Os modelos empíricos mostraram-se de fácil aplicação, porém apresentaram limitações. O modelo de Araya Moya (1994) incorpora parâmetros da bacia importantes na deflagração e dinâmica das corridas de detritos, porém foi calibrado para uma região de diferente aspecto fisiogeográfico da Serra do Mar. Além disso, foi ajustado para uma precipitação acumulada em 24 horas não incorporando, portanto, a precipitação que antecede o evento. Acredita-se que para uma melhor aplicação deste modelo há necessidade de calibrá-lo considerando as características dos processos e das bacias e sub-bacias onde ocorrem, adequandoo para a realidade brasileira.

O modelo de Massad et al. (1997) foi proposto com base em casos nacionais, porém considera apenas a área da bacia, não incorporando outros aspectos do relevo que podem contribuir na dinâmica destes processos. Um aspecto importante neste modelo é a inclusão da intensidade de precipitação que antecede o evento e que vem demostrando ser um fator importante na deflagração das corridas de detritos no Brasil. 
Acredita-se que a integração de outras variáveis nos modelos existentes atualmente pode contribuir na estimativa do volume de sedimentos das corridas de detritos. Como observado por D'Agostino e Marchi (2001), muitos dos fatores geológicos, geomorfológicos, hidrológicos e uso do solo que contribuem na deflagração e na magnitude das corridas de detritos não são considerados nestes modelos empíricos. Para estes autores, o emprego de métodos empíricos para estimar o volume de sedimentos (magnitude) das corridas de detritos é o primeiro passo para o zoneamento de áreas propensas a ocorrência destes processos. 


\subsection{Classificação quanto à magnitude do evento}

Por meio dos resultados obtidos nesta pesquisa, somado aos eventos registrados por Kanji et al. (2003) na Tabela 1, foi possível classificar a magnitude (volume de sedimentos) dos eventos ocorridos no Brasil com base na classificação proposta por Jakob (2005) conforme Tabela 2.

O volume total de sedimentos gerados por estes processos para as subbacias analisadas do rio Santo Antônio, para os cenários de $60 \mathrm{~mm} / \mathrm{h}$ e $100 \mathrm{~m} / \mathrm{h}$ foram entre 3.198.867,86 a 4.265.546,04 $\mathrm{m}^{3}$ e 5.331.446,43 a 7.109.243,40 $\mathrm{m}^{3}$, respectivamente. Para a bacia do Guaxinduba, estes volumes variaram, para os cenários de $60 \mathrm{~mm} / \mathrm{h}$ e $100 \mathrm{~mm} / \mathrm{h}$, entre 889.762,04 a 1.491.486,43 $\mathrm{m}^{3}$ e $1.499 .603,40$ a 2.485.810,72 $\mathrm{m}^{3}$, respectivamente. Estes totais de sedimentos para a bacia do Mococa variaram entre 2.032.345,44 a 2.178.333,06 $\mathrm{m}^{3}$ para o cenário de $60 \mathrm{~mm} / \mathrm{h}$ e, entre $3.387 .242,40$ a $3.630 .555,10 \mathrm{~m}^{3}$ para o cenário de $100 \mathrm{~mm} / \mathrm{h}$.

Baseado na classificação de Jakob (2005), os eventos analisados neste estudo, considerando toda a sua magnitude, foram inseridos na classe 5 , tendo como características a ocorrência destes processos em locais com abundância de áreas fontes, ocorrendo de forma rara e, passíveis de serem interpretados pela exposição dos materiais em sua trajetória ou por análises sedimentológicas.

O quadro 3 mostra a hierarquização das sub-bacias em relação ao volume de sedimentos gerados em função dos modelos empíricos adotados. A fim de adaptar a classificação de Jakob (2005) para os resultados obtidos em relação ao potencial de geração de corridas (volume de sedimentos) destas bacias, buscou-se um melhor refinamento da hierarquização das sub-bacias.

As Figuras 49, 50 e 51 trazem os mapas de potencial de geração a corridas de detritos para as sub-bacias dos rios Santo Antônio, Guaxinduba e Mococa, com base nos cenários de 60 e $100 \mathrm{~mm} / \mathrm{h}$, segundo os modelos de Araya Moya (1994) e Massad et al. (1997). 
Quadro 3: Correlação entre as classes de Jakob (2005) e Nery (2015).

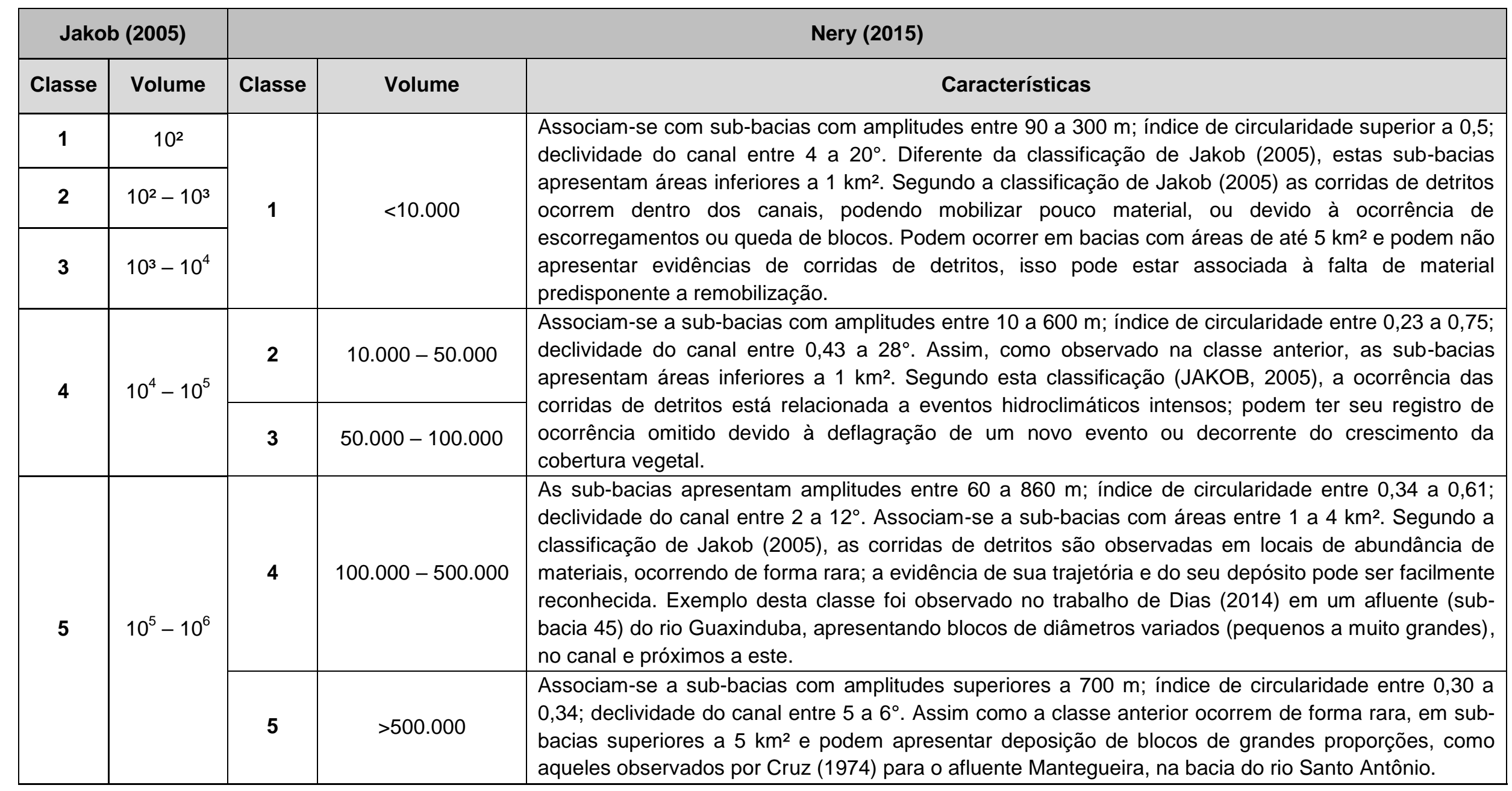

Fonte: elaborado por Nery (2015). 

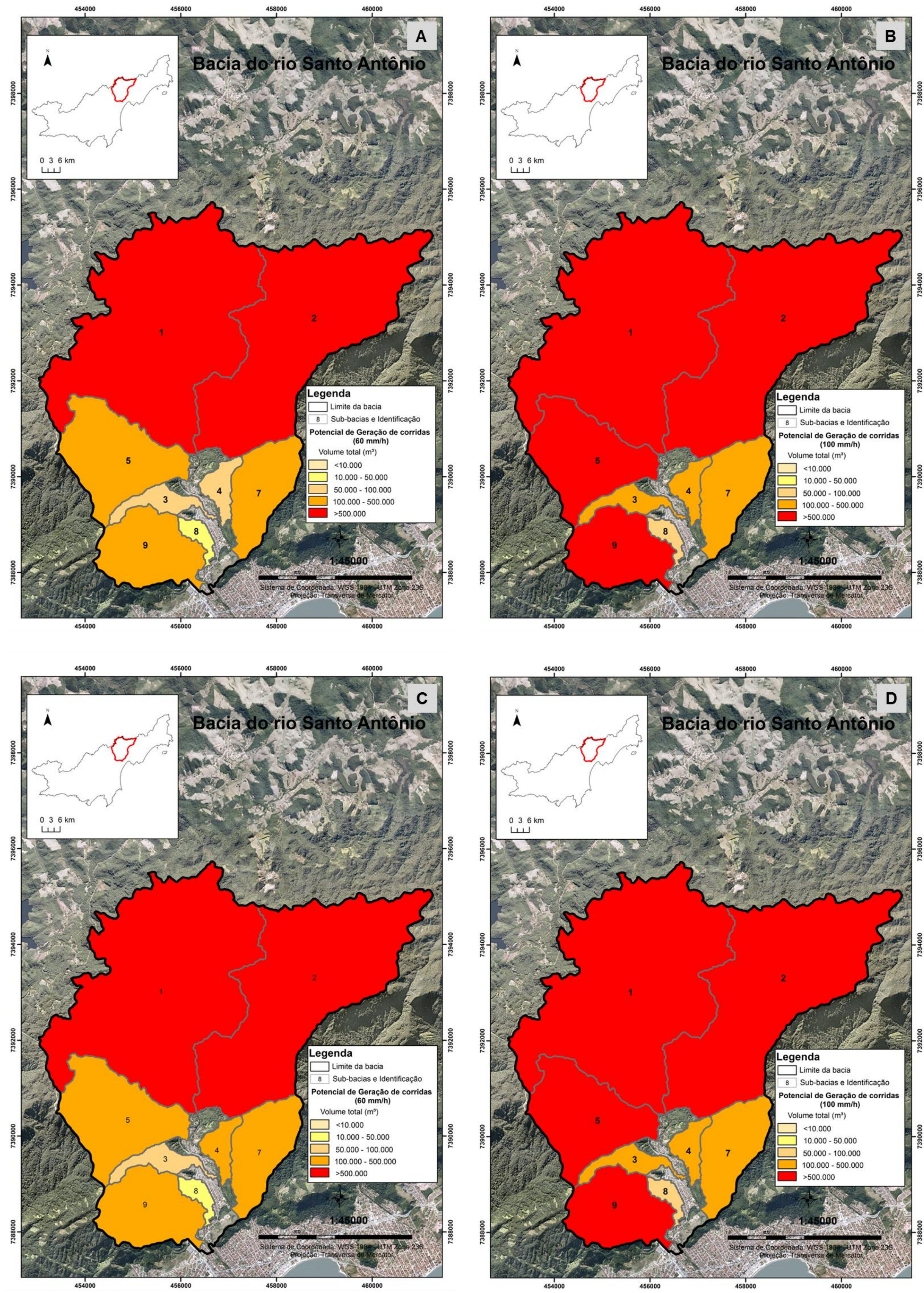

Figura 49: Mapa de potencial de geração de corridas de detritos para as sub-bacias do rio Santo Antônio. Figuras (a) e (b) representam os cenários de 60 $\mathrm{mm} / \mathrm{h}$ e $100 \mathrm{~mm} / \mathrm{h}$ para o modelo de Massad et al. (1997); (c) e (d) representam os cenários de $60 \mathrm{~mm} / \mathrm{h}$ e $100 \mathrm{~mm} / \mathrm{h}$ para o modelo de Araya Moya (1994). 

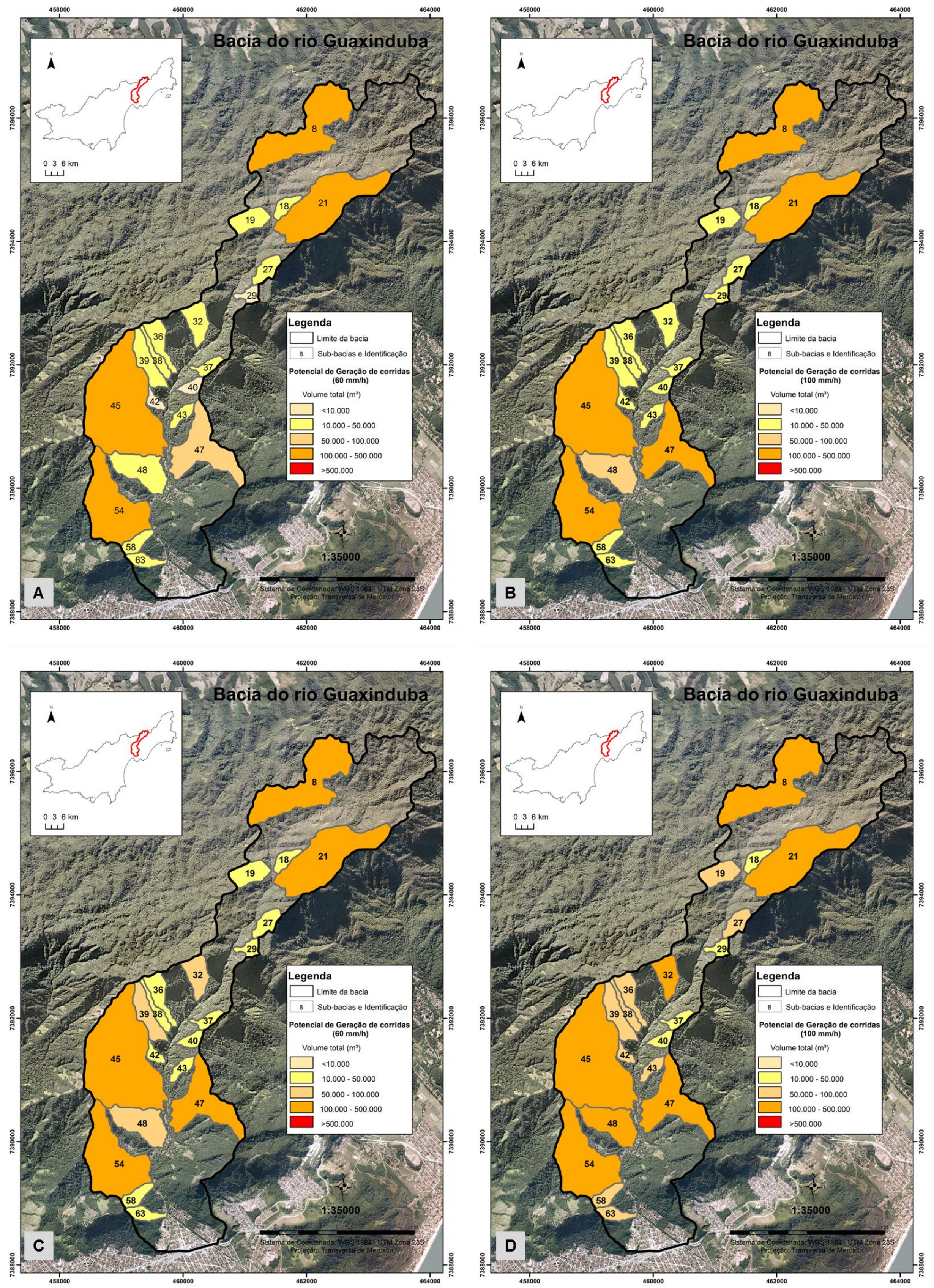

Figura 50: Mapa de potencial de geração de corridas de detritos para as sub-bacias do rio Guaxinduba. Figuras (a) e (b) representam os cenários de 60 $\mathrm{mm} / \mathrm{h}$ e $100 \mathrm{~mm} / \mathrm{h}$ para o modelo de Massad et al. (1997); (c) e (d) representam os cenários de $60 \mathrm{~mm} / \mathrm{h}$ e $100 \mathrm{~mm} / \mathrm{h}$ para o modelo de Araya Moya (1994). 

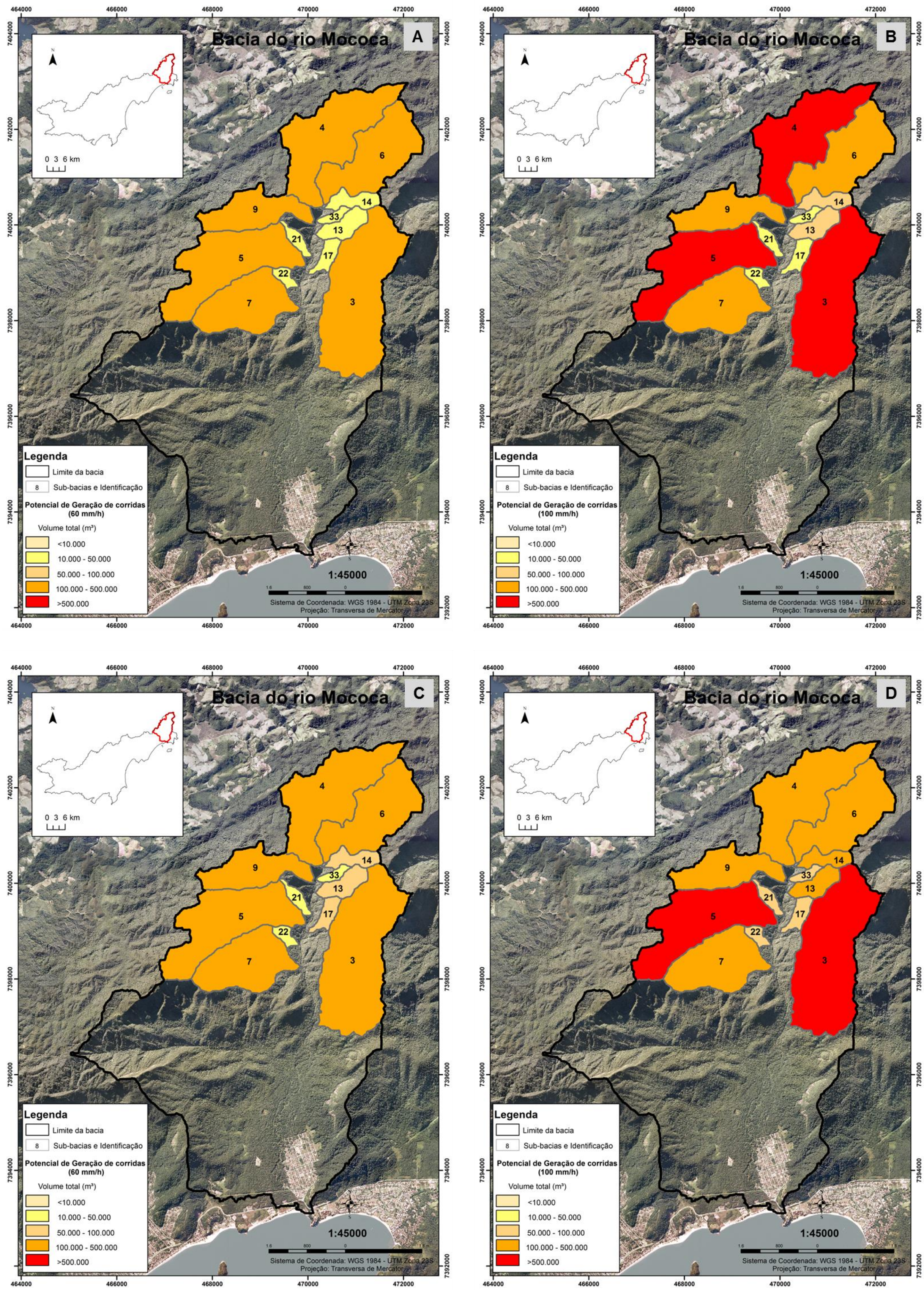

Figura 51: Mapa de potencial de geracão de corridas de detritos para as sub-bacias do rio Mococa. Figuras (a) e (b) representam os cenários de $60 \mathrm{~mm} / \mathrm{h}$ e $100 \mathrm{~mm} / \mathrm{h}$ para o modelo de Massad et al. (1997); (c) e (d) representam os cenários de 60 mm/h e $100 \mathrm{~mm} / \mathrm{h}$ para o modelo de Araya Moya (1994). 
De forma geral, as sub-bacias dos rios Santo Antônio e Mococa, em relação aos cenários propostos, inserem-se nas classes de 2 a 5 dos mapas, com volumes de sedimentos entre 10.000 a $>500.000 \mathrm{~m}^{3}$ e correspondem, em relação à classificação de Jakob (2005) as classes 4 e $5\left(10^{4}\right.$ a $\left.10^{6} \mathrm{~m}^{3}\right)$. Estas classes caracterizam-se pela ocorrência destes processos com período de retorno de várias décadas, para sub-bacias inferiores a $5 \mathrm{~km}^{2}$, ou tempo de retorno de 100 anos para sub-bacias superiores a $5 \mathrm{~km}^{2}$; os registros destes processos podem ser perdidos devido a outros processos erosivos ou devido ao crescimento da cobertura vegetal; e podem ocorrer de forma rara sendo interpretados pela exposição natural dos seus materiais e/ou da sua trajetória.

Ressalta que para estas sub-bacias, valores inferiores a $10.000 \mathrm{~m}^{3}$ não foram observados. Além disso, os valores obtidos neste trabalho para algumas destas subbacias foram superiores ao valor limite referente à classe $5\left(10^{6} \mathrm{~m}^{3}\right)$, proposta por Jakob (2005).

A bacia do rio Guaxinduba apresentou comportamento distinto quanto à magnitude destes processos. As sub-bacias foram hierarquizadas entre as classes 1 a 4 dos mapas (<10.000 a $\left.500.000 \mathrm{~m}^{3}\right)$, correspondendo às classes 1 a $5\left(10^{2}\right.$ a $10^{6}$ $\mathrm{m}^{3}$ ) de Jakob (2005), indicando a ocorrência destes processos em pequenos canais, mobilizando pouco material. As corridas de detritos podem ocorrer dentro do próprio canal ou devido à ocorrência de escorregamentos e queda de blocos; associadas a tempo de retorno de décadas até 100 anos e seu registro pode ou não ser interpretados ao longo de sua trajetória, dependendo do estágio de desenvolvimento da cobertura vegetal ou da reativação destes processos.

Analisando os casos nacionais contemplados na Tabela 1, os eventos da Refinaria Presidente Bernardes, em Cubatão (SP), e nas bacias do Quitite e Papagaio, no Maciço da Tijuca, no Rio de Janeiro (RJ), foram inseridos na classe 4 (volumes $=10^{4}-10^{5}$ ) segundo a classificação de Jakob (2005), onde possíveis danos associam-se a destruição de obras de grandes dimensões, pilastras de pontes, bloqueando ou danificando rodovias, dutos e vilas ou bairros. No primeiro evento, a infraestrutura da refinaria foi danificada pela inundação em suas instalações que paralisaram suas atividades operacionais; no segundo, centenas de 
casas foram destruídas levando a ocorrência de uma vítima (KANJl et al., 2003). Segundo a classificação, eventos desta magnitude são esperados para precipitações com período de retorno de 100 anos.

No entanto, estes processos vêm ocorrendo dentro de um período de 10 anos, mesmo não apresentando a mesma magnitude. Este é o caso da Refinaria Presidente Bernardes, em Cubatão (SP). Após a construção de infraestruturas para o controle de corridas deflagradas em 1994, o evento de 1996 neste local necessitou apenas de limpeza das áreas atingidas. Mesmo assim, dado o volume observado este evento foi inserido na classe 3 (volumes $=10^{3}-10^{4}$ ). No segundo evento, muitas casas foram atingidas, contabilizando uma vítima (KANJI et al., 2003).

Os eventos ocorridos nas bacias dos rios Cachoeira em 1976, em Cubatão (SP) e na Rodovia Anchieta (SP), em 1999, foram inseridos na classe 4 de Jakob (2005). Estes eventos ocasionaram a inundação do Pólo Industrial de Cubatão, interrupção da operação do polo e do tráfego, interrompendo a circulação entre o planalto e a faixa litorânea (KANJI et al., 2003). Estes danos corroboram as características desta classe, implicando para eventos futuros, perdas econômicas e danos socioambientais irreparáveis.

A classe 5 (volumes $=10^{5}-10^{6}$ ) apresenta como possíveis danos a destruição parcial de uma cidade, isolando e impossibilitando o acesso a estas áreas, obstrução de rios e córregos, destruição parcial de florestas (JAKOB, 2005). Nesta classe inserem-se os eventos da Serra das Araras (RJ), Caraguatatuba (SP), Grota Funda (SP), Timbé do Sul (SC/RS) e Lavrinhas (SP), todos com volume de sedimentos superiores $1.000,000 \mathrm{~m}^{3}$. Estes eventos, no total, causaram mais de 1360 mortos, destruição de casas, danos em vias de circulação (rodovias e ferrovias) e perdas associadas à agricultura e criação de gado, obstrução de rios e córregos (KANJl et al., 2003).

As informações aqui obtidas podem auxiliar no planejamento destas subbacias, pois segundo D'Agostino e Marchi (2001) o conhecimento sobre o volume de sedimentos (magnitude) que cada uma destas unidades pode gerar é o primeiro passo para o zoneamento destas áreas propensas a ocorrência das corridas de detritos. 


\section{CONCLUSÕES}

O presente trabalho demonstrou que $\mathrm{O}$ uso de parâmetros e índices morfométricos pode contribuir na avaliação do potencial de geração (volume de sedimentos) das corridas de detritos, comprovando a hipótese desta pesquisa. A confirmação da hipótese foi realizada por meio de análises qualitativa e quantitativa destes processos. Desta forma, tanto o objetivo principal quanto os objetivos específicos foram alcançados.

Devido à dificuldade de mensurar estes processos em campo, bem como, a sua análise temporal, procedimentos indiretos foram empregados nesta pesquisa. $O$ primeiro consistiu na fotointerpretação e no reconhecimento das formas resultantes destes processos por meio de fotografias aéreas; e o segundo na aplicação de modelos empíricos para avaliar o potencial de geração das corridas de detritos.

Houve dificuldade no georreferenciamento das fotografias aéreas de 1973 devido à ausência de objetos facilmente identificáveis que permitissem um melhor ajustamento das imagens. Além disso, devido à forma em que estes processos ocorreram, impossibilitando a sua identificação e a sua delimitação, utilizou-se de outras fontes de informações para compor o banco de dados. Aqui foi assumido que todos os escorregamentos contribuíram com $50 \%$ de sedimentos para as corridas de detritos.

O Modelo Digital de Terreno apresentou incoerências, porém, observou-se que as mesmas não propagaram erros relevantes para a análise final. No entanto, ressalta-se que para uma análise mais complexa, por exemplo, aplicação de modelos dinâmicos, será necessária outra avaliação para minimizar as inconsistências que poderão surgir durante a construção do modelo digital.

Os resultados obtidos para a análise qualitativa apontam que o entendimento da dinâmica das corridas de detritos só será possível se interpretarmos a sua ocorrência de forma conjunta. Os parâmetros morfométricos para as bacias do Santo Antônio, Guaxinduba e Mococa apresentaram comportamento similares, com exceção da área da bacia, total da rede de drenagem e do índice de circularidade. 
Os maiores tempos de concentração destas bacias, somados ao comprimento do canal e aos baixos valores de declividade média do canal, indicam maior probabilidade de acúmulo de sedimentos ao longo da calha do rio. No entanto, acredita-se que em eventos extremos este tempo de concentração diminua e juntamente com o alto índice de densidade de drenagem favoreça a um escoamento mais rápido.

Estas informações permitem concluir que a bacia do rio Guaxinduba apresenta características que revelam uma maior suscetibilidade a ocorrência das corridas de detritos, respondendo de forma muito mais rápida às alterações das dinâmicas hidrológicas, escoando com mais facilidade os sedimentos provenientes dos escorregamentos e, consequentemente das corridas de detritos.

Em relação à ocorrência das corridas de detritos em bacias de dimensões similares (Santo Antônio e Mococa), observou-se uma melhor compreensão na deflagração destes processos em escala de sub-bacias. As sub-bacias, onde houve a ocorrência destes processos, apresentaram áreas entre 1 e 13 km² e amplitudes superiores a $500 \mathrm{~m}$, estando de acordo com as características observadas na literatura. Estas sub-bacias apresentaram densidade de drenagem variando entre 3,62 e 4,21 podendo indicar alta capacidade de transporte de sedimentos. Neste contexto, as sub-bacias do Mococa apresentaram características de maior suscetibilidade à ocorrência das corridas de detritos.

A respeito dos métodos empíricos, 40 sub-bacias foram selecionadas para a avaliação do potencial de geração de corridas de detritos: Santo Antônio (8), Guaxinduba (20) e Mococa (12). Observou-se que houve o acréscimo da vazão de pico, assim como, do volume de sedimentos em relação ao aumento da área das sub-bacias. Além disso, notou-se que houve um aumento de cerca de $60 \%$ do volume de sedimentos em relação aos cenários de 60 e 100 mm/h. Sub-bacias de mesma ordem de grandeza responderam de forma similar, resultando em valores equivalentes para a vazão de pico e o volume de sedimentos.

Avaliando os modelos utilizados observou-se que a adição de variáveis torna a análise do modelo mais sensível. Esta variação entre os modelos decorre da utilização de mais de uma variável no modelo de Araya Moya (1994) devido às 
diferenças no comprimento do canal e da variação altimétrica (amplitudes) das subbacias de mesma ordem de grandeza. Acredita-se que a inserção (input) de mais variáveis no modelo pode acarretar em valores distintos na magnitude das corridas de detritos. Portanto, o modelo proposto por Araya Moya (1994) respondeu de forma mais significativa, em sua maior parte, para sub-bacias com áreas inferiores a $2 \mathrm{~km}^{2}$ e o modelo proposto por Massad et al. (1997) foi mais representativo para subbacias com áreas superiores a $3 \mathrm{~km}^{2}$.

Os parâmetros e os índices morfométricos mostraram-se, em sua maior parte, plausíveis na avaliação das corridas de detritos e, apresentam-se como boas ferramentas de análise a respeito destes processos. Contudo, salienta-se que entre estas variáveis, o índice de circularidade foi o que apresentou menor importância na análise, não contribuindo, de fato, para a ocorrência das corridas de detritos.

As principais vantagens deste método associam-se ao baixo custo de sua aplicação, tendo como base um Modelo Digital de Terreno com boa resolução e o processamento destes dados em ambiente SIG. No entanto, o método envolve uma complexidade inerente aos diferentes critérios que podem ser adotados no uso destes parâmetros e índices morfométricos, rem informações (dados) diferenciados.

Uma primeira tentativa de hierarquizar, de forma qualitativa, o potencial de geração destas sub-bacias em função da magnitude (volume de sedimentos) foi apresentada. Propostas de trabalhos futuros concernem em uma melhor avaliação dos critérios adotados por estes modelos empíricos. Além disso, para uma melhor análise, as observações de campo e/ou inclusão de outros parâmetros morfométricos podem contribuir para a validação destes modelos.

Acredita-se que ferramentas, como aquelas empregadas neste trabalho, possam auxiliar no planejamento das áreas onde ocorrem as corridas de detritos, minimizando assim, o impacto destes processos. Os resultados obtidos podem servir de base para estudos futuros, levando a construção de formulações que considerem outros aspectos do meio físico (geológicos e geomorfológicos) e ambiental. Por fim, acredita-se que os resultados alcançados possam contribuir junto aos sistemas de monitoramento e alerta por meio dos diferentes setores administrativos (público e/ou privado). 


\section{REFERÊNCIAS BIBLIOGRÁFICAS}

ALEOTTI, P.; CHOWDHURY, R. Landslides hazard assessment: summary review and new perspectives. Bull Eng. Geol. Env/Springer-Verlag, no 58, p. 21-44, 1999.

ALMEIDA, F.F.M. e CARNEIRO, C. D. R. Origem e Evolução da Serra do Mar. Revista Brasileira de Geociências, p. 135-150, 1998

ALVES, J. M. P., CASTRO, P. T. A. Influência de feições geológicas na morfologia da bacia do rio do Tanque (MG) baseada no estudo de parâmetros morfométricos e análise de padrões de lineamentos. Revista Brasileira de Geociências, v 33 (2), p. 117-124, 2003

ANDERSON, S. A.; SITAR, N. Analysis of rainfall-induced debris flows. Journal of Geotechnical Engineering, v. 121 (7), p. 544-552, 1995

ARAYA MOYA, V. Genesis de aluviones en la costa de zonas deserticas. In: I Simposio Panamericano de Deslizamientos, 1994, Guayaquil, Equador. Anais, Guayaquil. p. 186-200.

ARRUDA JUNIOR, E. R.; LOPES, E. S. S. Análise morfométrica em sub-bacias hidrográficas para monitoramento do risco potencial a corridas de massa (debris flows) na região serrana do Rio de Janeiro. In: Congresso Brasileiro de Geologia de Engenharia e Ambiental, 14., 2013, Rio de Janeiro. Anais, Rio de Janeiro,: ABGE, 2013. 1 CD Rom

AUGUSTO FILHO, O. O estudo das corridas de massa em regiões serranas tropicais: um exemplo de aplicação no município de Ubatuba, SP. In: Congresso Brasileiro de Geologia de Engenharia, 7., 1993, Poços de Caldas. Anais, Poços de Calda: ABGE, 1993, vol. 2, p. 63-72

AUGUSTO FILHO, O.; VIRGILI, J. C. Estabilidade de taludes. In: OLIVEIRA, A. M. S., BRITO, S. N. A. (Eds.) Geologia de engenharia. São Paulo: ABGE, p. 243-269 1998

AUGUSTO FILHO, O.; MAGALHÃES, F. S.; GRAMANI, M. F. Mass movement's susceptibility map of a highway system using GIS technology: a case study in Brazil. In: Geoline, 2005, Lyon, França, p. 11

AVELAR, A. S.; LACERDA, W. A.; COELHO NETO, A. L. Mecanismos de iniciação de fluxos detríticos no maciço da Tijuca, Rio de Janeiro (RJ): o caso da encosta do Soberbo. Revista Brasileira de Geomorfologia, 7, p. 73-83, 2006

ÁlvareZ, M. L. P.; ÁlVAREZ, D.; ÁlVAREZ, H. S.; MORAES, L. R. S.; SANTOS, M. E. P. Delimitação das bacias hidrográficas e de drenagem natural da cidade de Salvador. Revista Interdisciplinar de Gestão Social, v. 1(1), p. 107-129, 2012

BARBOSA, J. P. M. Estudo sobre a evolução dos eventos extremos de precipitação no setor Paulista da Serra do Mar. In: XVII Simpósio Brasileiro de Recursos Hídricos, São Paulo. p. 1-21, 2007

BARLOW, J.; MARTIN, Y.; FRANKLIN, S. E. Detecting translational landslide scars using segmentation of Landsat ETM+ and DEM data in the northern Cascade Mountains, British Columbia. Can, J. Remote Sensing, v. 29, p. 510-517, 2003 
BENDA, L. E.; CUNDY, T. W. Predicting deposition of debris flows in mountain channels. Journal Can. Geotech, 27, p. 409-417, 1990

BENDA, L.; VELDHUISEN, C.; BLACK, J. Debris flows as agents of morphological heterogeneity at low-order confluences, Olympic Mountains, Washington. Geological Society of America, v. 115 (9), p. 1110-1121, 2003

BERTI, M.; GENEVOIS, R.; SIMONI, A.; TECCA, P. R. Field observations of a debris flow event in the Dolomites. Geomorphology, v. 29, p. 265-274, 1999

BEVEN, K. J.; KIRKBY, M. J. A physically based, variable contributing area model of basin hydrology. Hydrological Sciences, v. 24, p. 43-69, 1979

BINI, G. M. P. Análise dos movimentos de massa nas microbacias fluviais: Saltinho, Belchior baixo, Sertão e Porto Arraial - Gaspar - Santa Catarina. 2012. p. 165. Dissertação (Mestrado em Geografia) - Centro de Filosofia e Ciências Humanas, Universidade Federal de Santa Catarina, Florianópolis, 2012

BOSQUILIA, R. W. D.; FIORIO, P. R.; BARROS, P. P. S.; MARTINS, J. A.; DUARTE, S. N. Comparação entre modelos de mapeamento automático de drenagens utilizando SIG. In: XV Simpósio Brasileiro de Sensoriamento Remoto - SBSR, Foz do Iguaçu, Paraná, Brasil, 13 a 18 de Abril de 2013, INPE, p. 5872-5879

BOVIS, M. J.; JAKOB, M. The role of debris supply conditions in predicting debris flow activity. Earth Surface Processes and Landforms, v. 24, p. 1039-1054, 1999

BRASIL. Lei $n^{\circ}$ 12.608, de 10 de abril de 2012. Institui a Política Nacional de Proteção e Defesa Civil - PNPDEC; dispõe sobre o Sistema Nacional de Proteção e Defesa Civil -SINPDEC e o Conselho Nacional de Proteção e Defesa Civil CONPDEC; autoriza a criação de sistema de informações e monitoramento de desastres; altera as Leis n ${ }^{\text {os }} 12.340$, de $1^{\circ}$ de dezembro de 2010,10.257, de 10 de julho de 2001, 6.766, de 19 de dezembro de 1979, 8.239, de 4 de outubro de 1991, e 9.394, de 20 de dezembro de 1996; e dá outras providências. Disponível em: http://www.planalto.gov.br/ccivil_03/_Ato2011-2014/2012/Lei/L12608.htm. Acessado em: agosto de 2015

BRUBACHER, J. P.; OLIVEIRA, G. G.; GUASSELLI, L. A. Suscetibilidade de enchentes a partir da análise das variáveis morfométricas na bacia hidrográfica do rio dos Sinos-RS. Anais XV Simpósio Brasileiro de Sensoriamento Remoto SBSR, Curitiba-PR, Brasil, 30 de Abril de 2011, INPE, p. 1279-1286

BUDETTA, P. Rockfall-induced impact force causing a debris flow on a volcanoclastic soil slope: a case study in southern Italy. Natural Hazards and Earth System Sciences, v.10, p.1995-2006, 2010

CAINE, N. The rainfall intensity - duration control of shallow landslides and debris flows. Geografiska Annaler., v. 62 A (1-2), p. 23-27, 1980

CAMPBELL, R. H. Soil slips, debris flows, and rainstorms in the Santa Monica Mountains and vicinity, southern California. U. S. Geological Survey Professional Paper, 851, p. 51, 1975

CANNON, S. H. An evaluation of the travel-distance potential of debris flows. Utah Department of Natural Resources, Miscellaneous Publication, v. 89 (2), p.41, 1989 
CHAMBERLIN, T. W. Basin morphometry data and data base. Ministry of Environment, Province British Columbia. APD Technical Paper 11. p. 15, 1982

CHANG, T. C.; CHIEN, Y. H. The application of genetic algorithm in debris flows prediction. Environmental Geology, v. 53, p. 339-347, 2007

CHEN, C. Y.; Yu, F. C. Morphometric analysis of debris flows and their source areas using GIS. Geomorphology, 129, p. 387-397, 2011

CHEN, C. Y.; LEE, W. J. Topographic features and the initiation of debris flows. Disponível: hhtp://www.interpraevent.at/palm-cms/upload files/Publikationnen/Tagungsbeitraege/2010. p. 69-79, 2010

CHRISTOFOLETTI, A. Análise morfométrica de bacias hidrográficas. Notícia Geomorfológica, v. 9, n. 18, p. 35-64, 1969

CHRISTOPHER, O.; IDOWU, A. O,; OLUGBENGA, A. S. Hydrological analysis of Onitsha north east drainage basin using geoinformatic techniques. World Applied Sciences Journal, v. 11 (10), p. 1297-1302, 2010

CHURCHILL, R. R. Aspect-induced differences in hillslope processes. Earth Surface Processes and Landforms, v. 7, p. 171-182, 1982

COE, J.A.; GODT, J. W.; BAUM, R. L.; BUCKNAM, R. C.; MICHAEI, J. A. Landslide susceptibility from topography in Guatemala. In: Lacerda, W. A.; Ehrlich, M.; Fontura, S. A. B.; Sayão, A. S. F. (Eds). Landslides: Evaluation and Stabilization, London, Taylor \& Francis Group, v 1, p. 69-78, 2004

COLANGELO, A. C. Os parâmetros de resistência ao cisalhamento e a estabilidade das encostas no Planalto de Paraíbuna e Serra de Caraguatatuba. Revista do Departamento de Geografia - USP, volume especial 30 anos, p. 112-129, 2012

CONEDERA, M.; PETER, L.; MARXER, P.; FORSTER, F.; RICKENMANN, D.; RE, $L$. Consequences of forest fires on the hydrogeological response of mountain catchments: A case study of the Riale Buffaga, Ticino, Switzerland. Earth Surface Processes and Landforms, v. 28, p. 117-129, 2003

CONFORTI, M.; AUCELLI, P. P. C.; ROBUSTELLI, G.; SCARCIGLIA, F. Geomorphology and GIS analysis for mapping gully erosion susceptibility in the Turbolo stream catchment (Northern Calabria, Italy). Natural Hazard, v. 56, p. 881898, 2011

CONQ, M.; SILVEIRA, C. S.; DOURADO, F. Processos geomorfológicos e danos derivados da corrida de detritos de janeiro de 2011 na bacia do córrego do Príncipe, Teresópolis - Região Serrana do Rio de Janeiro. Ciência e Natura, v. 37 (1), p. 93103, p. 2015

COROMINAS, J. The angle of reach as a mobility index for small and large landslides. Canadian Geotechnical Journal, v. 33, p. 260-271, 1996

COSTA, J. E. Physical geomorphology of debris flows. In Costa, J. E., and Fleisher, J. P., eds., Developments and applications of geomorphology, New York: Springer-Verlag. p. 268-317, 1984

COUSSOT, P.; MEUNIER, M. Recognition, classification and mechanical description of debris flows. Earth-Science Reviews, v. 40, p. 209-227, 1996 
CRUZ, O. A Serra do Mar e o Litoral na área de Caraguatatuba - SP. 1972. p. 181. Tese (Doutorado em Geografia) - Faculdade de Filosofia, Letras e Ciências Humanas, Universidade de São Paulo, São Paulo, 1974

CRUZ, O. Contribuição geomorfológica ao estudo de escarpas da Serra do Mar. Revista do Instituto Geológico, vol. 11 (1), p. 9-20, 1990

DAI, F. C.; LEE, C. F. Landslide characteristics and slope instability modeling using GIS, Lantau Island, Hong Kong. Geomorphology, v. 42, p. 213-228, 2002

DASH, P.; AGGARWAL, S. P.; VERMA, N. Correlation based morphometric analysis to understand drainage basin evolution: a case study of Sirsa river basin, Western Himalaya, India. Geography series, v. 59 (1), p. 35-58, 2013

DAVIES, T. R.; PHILLIPS, C. J.; PEARCE, A. J.; ZHANG, X. B. Debris flow behavior - an integrated overview. Erosion, Debris Flows and Environment in Mountain Regions. IAHS Publ., n209, p. 217-225, 1992

DAY, D. G. Drainage density variability and drainage basin outputs. Journal of Hydrology, v. 22 (1), p. 3-17, 1983

DE MATAUCO, A. I. G. Análisis morfométrico de la cuenca y de la red de drenaje del río Zadorra y sus afluentes aplicado a la peligrosidad de crecidas. Boletín de la Asociación de Geógrafos, v. 38, p. 311-329, 2004

DEWITTE, O.; DEMOULIN, A. Morphometry and kinematics of landslides inferred from precise in West Belgium. Natural Hazards and Earth System Sciences, v. 5, p. 259-265, 2005

DIAS, V. C. Análise da influência dos parâmetros morfológicos e morfométricos na geração de corridas de detritos em Caraguatatuba (SP). 2014, p. 73. TGI (Monografia em Geografia) - Faculdade de Filosofia, Letras e Ciências Humanas, Departamento de Geografia, Universidade de São Paulo, São Paulo, 2014

DOMINGUES, A. J. P.; LIMA, G. R.; ALONSO, M. T. A.; BULHÔES, M. G. Serra das Araras: os movimentos coletivos do solo e aspectos da flora. Revista Brasileira de Geografia $33(3)$, p. 3-50, 1971

DYMOND, J. R.; AUSSEIL, A. G.; SHEPHERD, J. D.; BUETTNER, L. Validation of a region-wide model of landslide susceptibility in the Manawatu-Wanganui region of New Zealand. Geomorphology, v. 74, p. 70-79, 2006

D'AGOSTINO, V.; MARCHI, L. Debris flow magnitude in the Eastern Italian Alps: Data collection and Analysis. Physics and Chemistry of the Earth, v. 26 (9), p. 657663, 2001

ELLEN, S. D.; FLEMING, R. W.; LEE, H. J. Mobilization of debris flows from shallow slides. Erosion and Sedimentation in the Pacific Rim. Proceedings the Corvallis Symposium, August, 1987. IAHS Publ., n 165, p. 243-244, 1987

ELLEN, S. D.; MARK, R. K.; CANNON, S. H.; KNIFONG, D. L. Map of debris-flow hazard in the Honolulu District of Oahu, Hawaii. United States Geological Survey Open-File Report 93-213, p. 24, 1993 
EMPRESA PAULISTA DE PLANEJAMENTO METROPOLITANO S/A. Sistema de Compartilhamento de Dados Geoespaciais da Emplasa, p. 9. Disponível em: http://www.scd.emplasageo.sp.gov.br/Contents/Documentos/SCD-

Informacoes\%20sobre\%20os\%20produtos\%20do\%20SCM.pdf. Acesso em: $17 / 01 / 2016$

ESRI 2012. ArcGIS Desktop: Release 10. Redlands, CA: Environmental Systems Research Institute.

FANNIN, R.J.; ROLLERSON, T. P. Debris flows: some physical characteristics and behavior. Canadian Geotechnical Journal. Vol. 30, p. 71-81, 1992

FANNIN, J.; BOWMAN, E. T. Debris flows - entrainment, deposition and travel distance. Geotechnical News, v. 25 (4), p. 3-6, 2008

FELL, R. Landslide risk assessment and acceptable risk. Canadian Geotechnical Journal, v. 31(2), p. 261-272, 1994

FLORIS, M.; ALPAOS, A. D.; SQUARZONI, C.; GENEVOIS, R.; MARANI, M. Recent changes in rainfall characteristics and their influence on thresholds for debris flow triggering in the Dolomitic area of Cortina d'Ampezzo, north-eastern Italian Alps. Natural Hazards and Earth System Sciences, v. 10, p. 571-580, 2010

FONSECA, B. M.; AUGUSTIN, C. H. R. R. Análise morfométrica de bacias de drenagem e sua relação com a estrutura geológica, Serra do Espinhaço MeridionalMG. Revista Brasileira de Geomorfologia, vol. 15, n², p. 153-172, 2014

FULFARO, V.; PONÇANO, W. L.; BISTRICHI, C. A.; STEIN, D. P. Escorregamentos de Caraguatatuba: expressão atual, e registro na coluna sedimentar da planície costeira adjacente. In: Congresso Brasileiro de Geologia de Engenharia, 1976. Anais... Rio de Janeiro: ABGE, 1976. v. 2, p. 341-350

GAO, J. Identification of topography setting conducive to landsliding from DEM in Nelson Country, Virginia, U.S.A. Earth Surface Processes and Landforms, v. 18, p. 579-591, 1993

GARBRECHT, J.; MARTZ, L. Grid size dependency or parameters extracted from Digital Elevation Models. Computers \& Geosciences, v. 20 (1), p. 85-87, 1994

GARTNER, J. E.; CANNON, S. H.; SANTI, P. M.; DEWOLFE, V. G. Empirical models to predict the volumes of debris flows generated by recently burned in the western U.S. Geomorphology, v. 96, p. 339-354, 2008

GLADE, T. Linking debris-flow hazard assessments with geomorphology. Geomorphology, 66, p. 189-213, 2005

GODT, J. W.; COE, J. A. Alpine debris flows triggered by a 28 July 1999 thunderstorm in the central Front Range, Colorado. Geomorphology, v. 84, p. 8097, 2007

GOMES, R. A. T. Modelagem de previsão de movimentos de massa a partir da combinação de modelos de escorregamentos e corridas de massa. 2006. p. 180. Tese (Doutorado em Geografia) - Instituto de Geociência, Universidade Federal do Rio de Janeiro, Rio de Janeiro, 2006. 
GRAMANI, M. F. Caracterização Geológico-Geotécnica das Corridas de Detritos ("Debris Flows") no Brasil e Comparação com Alguns Casos Internacionais. (2001). p. 372. Dissertação (Mestrado em Engenharia) - Escola Politécnica, Universidade de São Paulo, São Paulo, 2001.

GRAMANI, M. F. A corrida de detritos (debris flow) no ribeirão Cágado, Serra do Mar, município de Cubatão, SP. In: VI Conferência Brasileira de Encostas, 2013. Anais...Angra dos Reis, Rio de Janeiro: COBRAE, 2013. p. 88-95

GUIDICINI, G.; NIEBLE, C. M. Estabilidade de Taludes Naturais e de Escavação. São Paulo: Editora da USP, 1976. p. 216.

GUTHRIE, R. H.; EVANS, S. G. Analysis of landslide frequencies and characteristics in natural system, Coastal British Columbia. Earth Surface Processes and Landforms, v. 29, p. 1321-1339, 2004a

GUTHRIE, R. H.; EVANS, S. G. Magnitude and frequency of landslides triggered by a storm event, Loughborough Inlet, British Columbia. Natural Hazards and Earth System Sciences, v. 4, p. 475-483, 2004b

GUZZETTI, F.; ARDIZZONE, F.; CARDINALI, M.; ROSSI, M.; VALIGI, D. Landslide volume and landslide mobilization rates in Umbria, central Italy. Earth and Planetary Science Letters, v. 279, p. 222-229, 2009

GUZZETTI, F.; MONDINI, A. C.; CARDINALI, M.; FIORUCCI, F.; SANTANGELO, M.; CHANG, K. T. Landslide inventory maps: new tools for an old problem. Earth Science Reviews, v. 112, p. 42-66, 2012

HAJAM, R. A.; HAMID, A.; BHAT, S. Application of morphometric analysis for geohydrological studies using geo-spatial technology - A case study of Vishav drainage basin. Hydrology Current Research, vol 4, n³, p. 1-12, 2013

HANCOX, G. T.; COX, S.; TURNBULL, I. I.; CROZIER, M. J. (2003). Reconnaissance studies of landslides and other ground damage caused by the Mw 7.2 Fiordland earthquake of 22 August 2003. Institute of Geological e Nuclear Sciences, science report 2003/30. 32 p

HASEGAWA, S.; NONOMURA, A.; NAKAI, S.; DAHAL, R. K. Drainage density as rainfall induced landslides susceptibility index in small catchment area. International Journal Lands and Environmental, v. 1(1), p. 27-28, 2013

HASUI, Y.; MIOTO, J. A.; MORALES, N. Geologia do Pré-Cambriano. In: FALCONI, F. F.; JUNIOR, A. N. (Org.), Solos do Litoral de São Paulo. São Paulo: ABMS, 1994. p. 41-67.

HATTANJI, T.; MORIWAKI, H. Morphometric analysis of relic landslides using detailed landslide distribution maps: implications for forecasting travel distance of future landslides. Geomorphology, 103, p. 447-454, 2009

HAVENITH, B.H.; STROM, A.; CACERES, F.; PIRARD, E. Analysis of landslides susceptibility in the Suusamyr region, Tien Shan: statistical and geotechnical approach. Landslide, no 3, p. 39-50, 2006 
HELSEN, M. M.; KOOP, P. J. M.; STEIJN, H. V. Magnitude-frequency relationship for debris flows on the fan of the Chalance torrent, Valgaudemar (French Alps). Earth Surface Processes and Landforms, v. 27, p. 1299-1307, 2002

HORTON, R. E. Erosional development of streams and their drainage basins: hydrophsysical approach to quantitative morphology. Geological Society of America Bulletin, $n^{\circ}$ 56, p. 257-370, 1945.

HURLIMANN, M.; RICKENMANN, D.; GRAF, C. Field and monitoring data of debrisflow events in the Swiss Alps. Canadian Geotechnical Journal, v. 40, 161-175, 2003

IKEYA, H. A method of designation for area in danger of debris flow. Erosion and Sediment Transport in Pacific Rim Steeplands, I. A. M. S., n 132, p. 576-588, 1981.

INSTITUTO DE PESQUISA TECNOLÓGICAS DO ESTADO DE SÃO PAULO. Estudos das instabilizações de encosta da Serra do Mar na região de Cubatão objetivando a caracterização do fenômeno "corrida de lama" e da prevenção dos seus efeitos. São Paulo, 1987. Relatório 26.258, volume 1.

INSTITUTO DE PESQUISA TECNOLÓGICAS DO ESTADO DE SÃO PAULO. Instabilidade das encostas da Serra do Mar voltadas ao parque industrial de Cubatão (SP): diagnose, soluções e ações de emergência. São Paulo, 1986

INSTITUTO DE PESQUISA TECNOLÓGICAS DO ESTADO DE SÃO PAULO. Reconhecimento, caracterização e monitoramento de locais potencialmente sujeitos a instabilizações na Serra do Mar na área de influência dos diversos Sistemas de Captação e Abastecimento de Água e de Tratamento de Esgoto. São Paulo, 2002. Relatório 59.123.

INSTITUTO DE PESQUISAS TECNOLOGICAS DO ESTADO DE SÃO PAULO, SERVIÇO GEOLOGICO DO BRASIL. Cartas de suscetibilidade a movimentos de massa e inundações: 1:25.000. Nota explicativa. São Paulo, 2014 Publicação IPT, 3016

IVERSON, R. M.; REID, M. E.; LAHUSEN, R. G. Debris-flow mobilization from landslides. Annu. Rev. Earth Planet, SCi, 25, p. 85-138, 1997.

JACKSON, L. E. Debris flows hazard in the Canadian Rocky Mountains. Geological Survey of Canada, Paper 86-11, p. 20, 1987

JAKOB, M. Morphometric and geotechnical controls of debris flow: frequency and magnitude in southern British Columbia. (1996). p. 242. Tese (Doutorado em Filosofia) - Departamento de Geografia, Universidade de Columbia Britânica, Canadá

JAKOB, M. A size classification for debris flows. Engineering Geology, v.79, p. 151161,2005

JAKOB, M.; FRIELE, P. Frequency and magnitude of debris flows on Chekeye river,

British Columbia. Geomorphology, v. 114, p. 382-395, 2010

JOHNSON, P. A.; McCUEN, R. H.; HROMADKA, T. V. Magnitude and frequency of debris flows. Journal of Hydrology, v. 123, p. 69-82, 1991 
JONES, F. O. Landslides of Rio de Janeiro and the Serra das Araras Escarpment, Brazil. U. S. Geological Survey Professional Paper, 697, p. 42, 1973

KAKEMBO, V; XANGA,W. W.; ROWNTREE, K. Topographic thresholds in gully development on the hillslopes of commnual areas in Ngqushwa local municipally, Eastern Cape, South Africa. Geomorphology, v. 110, p. 188-194, 2009

KANJI, M. A.; MASSAD, F.; CRUZ, P. T. Debris Flows in Areas of Residual Soils: Occurrence and Characteristics. In: International Workshop on Occurrence and Mechanism of Flows in Natural Slopes and Earthfills, 2003, Sorrento. International Workshop on Occurrence and Mechanism of Flows in Natural Slopes and Earthfills. Napoles : Associacione Geotecnica Italiana, 2003. v. 2. p. 1-9

KANJI, M. A.; CRUZ, P. T.; MASSAD, F. Debris flow affecting the Cubatão Oil Refinery, Brazil. Landslides, vol. 5, p. 71-82, 2008

KOBIYAMA, M.; GOERL, R. F.; CORRÊA, G. P.; MICHEL, G. P. Debris flow occurrences in Rio dos Cedros, Southern Brazil: meteorological and geomorphic aspects. WIT Transactions on Engineering Sciences, vol. 67, p. 77-88, 2010.

KOBIYAMA, M.; MOTA, A. A.; GRISON, F.; GIGLIO, J. N. Landslide influence on turbidity and total solids in Cubatão do Norte river, Santa Catarina, Brazil. Natural Hazards, vol. 59, p. 1077-1086, 2011.

KOBIYAMA, M.; MICHEL, G. P. Bibliografia dos trabalhos de fluxos de detritos ocorridos no Brasil no período de 1949-2014. Trabalho Técnico GPDEN, n 01, p. 15,2014

LAING, B. R. Integrating drainage enforcement into existing raster digital elevation models. (2004). p. 31. Dissertação (Mestrado em Geografia) Departamento de Geografia, Universidade de Saskatchewan, Canadá

LAN, H. X.; ZHOU, C. H.; WANG, L. J.; ZHANG, H. Y.; LI, R. H. Landslide hazard spatial analysis and prediction using GIS in the Xiaojiang watershed, Yunnam, China. Engineering Geology, v. 76, p. 109-128, 2004

LANGBEIN, W. B. Topographic characteristics of drainage basins. Geological Survey water-supply, v. 968-C, p. 125-157, 1947

LAWSON D. E. Mobilization, movement and deposition of active subareal sediment flows, Matanuska glacier, Alaska. Journal of Geology, vol. 90, p. 279-300, 1982. Doi: 0022-1376/82/9003-00651.00

LEROI, E.; ROUZEAU, O.; SCANVIC, J. Y.; WEBBER, C. C.; CUERVOS, G. V. Remote sensing and GIS technology in landslide hazard mapping in the Colombian Andes. Episodes, v. 15 (1), p. 32-35, 1992

LIMA, I. F. O fluxo gravitacional de massa do Vieira, Teresópolis - RJ, Megadesastres de 2011: Descrição e Classificação. In: VI Conferência Brasileira de Encostas, 2013. Anais...Angra dos Reis, Rio de Janeiro: COBRAE, 2013. p. 139-144

LINDSAY, J.; CREED, I. F. Sensitivity of digital landscapes to artifact depressions in remotely-sensed DEMs. Photogramametric Engineering and Remote Sensing, v. 71 (9), p. 1029-1036, 2005 
LOPES, E. S. S. Modelagem especial dinâmica em Sistema de Informação Geográfica: Uma aplicação ao estudo de movimentos de massa em uma Região da Serra do Mar Paulista. (2006), p. 314.Tese (Doutorado em Geociências e Meio Ambiente) - Instituto de Geociências e Ciências Exatas, Universidade Estadual Paulista, Rio Claro, 2006

MANTOVANI, F.; SOETERS, R.; VAN WESTEN, C.J. Remote sensing techniques for landslide studies and hazard zonation in Europe. Geomorphology, v. 15, p. 213225, 1996

MARCHI, L.; D'AGOSTINO, V. Estimation of debris-flow magnitude in the Eastern Italian Alps. Earth Surface Processes and Landforms, v. 29, p. 207-220, 2004

MARCHI, L; FONTANA, G. D. GIS morphometric indicators for the analysis of sediment dynamics in mountain basins. Environmental Geology, v. 48, p. 218-228, 2005

MARTIN, Y,; ROOD, K.; SCHWAB, J. W.; CHURCH, M. Sediment transfer by shallow landsliding in the Queen Charlotte islands, British Columbia. Canadian Journal of Earth Sciences, v. 39, p. 189-205, 2002

MARSTON, R. A.; FRITZ, D. E.; NORDBERG, V. The impact of debris torrents on subtrates of mountain streams. Géomorphologe: Relief, processus, environnement, v. 1, p. 21-32, 1997

MASSAD, F., CRUZ, P. T., KANJI, M. A., ARAUJO FILHO, H. A. Comparison between estimated and measured debris flows discharges and volume of sediments. In: 2nd Panamerican Symposium on Landslide e $2^{\circ}$ Congresso Brasileiro de Estabilidade de Encosta - COBRAE, 1997 ABMS/ABGE, Rio de Janeiro, 1997: p. 213-222

MELELLI, L.; TARAMELLI, A. An example of debris-flow hazard modeling using GIS. Natural Hazard and Earth System Sciences, v. 4, p. 374-358, 2004

MIZUYAMA, T. Analysis of sediment yield and transport data for erosion control works. Recent Developments in the Explanation and Prediction of Erosion and Sediment Yield. Proceedings Exeter Symposium, July: 82, IAHS Publ., $\mathrm{n}^{\circ}$ 137, p. 177-182, 1982

MONTGOMERY, D. R.; DIETRICH, W. E.; TORRES, R.; ANDERSON, S. P.; HEFFNER, J. T.; LOAGUE, K. Hydrologic response of a steep, unchanneled valley to natural and applied rainfall. Water Resources Research, vol. 33, n¹, p. 91-109, 1997

MOORE, I. D.; GRAYSON, R. B.; LADSON, A. R. Digital terrain modeling: A review of hydrological, geomorphological, and biological applications. Hydrological Processes, vol. 5, p. 3-30, 1991

MOREIRA, S. M. Frequency of debris flows and rockfall along the Mendoza river valley (Central Andes), Argentina: Associated risk and future scenario. Quaternary International, v. 458, p. 110-121, 2006

MOTTA, H. P. G. Avaliação de corridas de detritos para a previsão de eventos futuros (2014). p. 254. Tese (Doutorado em Engenharia) - COPPE, Universidade Federal do Rio de Janeiro, Rio de Janeiro, 2014. 
MUKHERJEE, S.; MUKHERJEE, S.;GARG, R. D.; BHARDWAJ, A.; RAJU, P. L. N. Evaluation of topographic index in relation to terrain roughness and DEM grid spacing. Journal System Sciences, v. 122 (3), p. 869-886, 2013

NEFESLIOGLU, H. A.; DUMAN, T. Y.; DURMAZ, S. Landslide susceptibility mapping for a part of tectonic Kelkit Valley (Eastern Black Sea region of Turkey). Geomorphology, v. 94, p. 401-418, 2008

NETTLETON, M. I.; MARTIN, S.; HENCHER, S.; MOORE, R. (2005). Debris flow types and mechanisms. In: Winter, M. G.; Macgregor, F.; Shackman (Eds). Press. Scottish road network Landslides study summary report, Scottish, p. 1-19.

NIKOLAEVA, E.; WALTER, T. R.; SHIRZAEI, M.; ZSCHAU, J. Landslide observation and volume estimation in central Georgia based on L-band InSAR. Natural Hazards and Earth System Sciences, v. 14, p. 675-688, 2014

OLIVEIRA, S. N.; CARVALHO JÚNIOR, O. A.; SILVA, T. M.; GOMES, R. A. T.; MARTINS, E. S.; GUIMARÃES, R. F.; SILVA, N. C. Delimitação automática de bacias de drenagens e análise multivariada de atributos morfométricos usando Modelo Digital de Elevação Hidrologicamente corrigido. Revista Brasileira de Geomorfologia, v. 8 (1), p. 3-21, 2007

O'CALLAGHAN, J. F.; MARK, D. M. The extraction of drainage networks from Digital Elevation Data. Computer vision, graphics, and image processing, v. 28, p. 323344,1984

O'LOUGHLIN, E. M. Saturation regions in catchments and their relations to soil and topographic properties. Journal of Hydrology, 53, p. 229-246, 1981

PELFINI, M.; SANTILLI, M. Frequency of debris flows and their relation with precipitation: A case study in the Central Alps, Italy. Geomorphology, v. 101, p. 721 730, 2008

PELLEGATTI, C. H. G.; GALVANI, E. Avaliação da precipitação na Serra do Mar-SP em eventos de diferentes intensidade e duração. GEOUSP - Espaço e Tempo, São Paulo, № 27, pp. 147 - 158, 2010

PELLERIN, J.; DUARTE, G. M.; SCHEIBE, L. F.; MENDONÇA, M.; BUSS, M. D.; MONTEIRO, M. A. Timbé do Sul - Jacinto Machado: Avaliação preliminar da extensão da catástrofe de 23-24/12/1995. Geosul, v. 12 (23), p. 71-86, 1997

PERUCCA, L. P.; ANGILIERI, Y. E. Morphometric characterization of del Molle Basin applied to the evaluation of flash foods hazard, Iglesia Department, San Juan, Argentina. Quaternary International, v. 233, p. 81-86, 2011

PETERSON, D. M.; ELEN, S. D.; KNIFONG, D. L. Distribution of past debris flows and other rapid slope movements from natural hillslopes in the Honolulu District of Oahu, Hawaii. United States Geological Survey Open-File Report 93-514, p. 32, 2 pls, 1993

PIERSON, T. H. Piezometric response to rainstorms in forested hillslope drainage depressions. Journal of Hydrology: v. 19, number 1, p. $1-9,1980$.

PINHO, G. M.; FRANCISCO, C. N.; SALGADO, C. M. Análise espacial dos movimentos de massa em Nova Friburgo/RJ: o caso do desastre natural de janeiro de 2011. Tamoios, v. 9 (1), p. 16-27, 2013 
POLANCO, L. S. E. Correlações empíricas para fluxo de detritos. (2010). p. 126. Dissertação (Mestrado em Engenharia) - COPPE, Universidade Federal do Rio de Janeiro, Rio de Janeiro, 2010.

PORTILLA, M.; CHEVALIER, G.; HURLIMANN, M. Description and analysis of the debris flows occurred during 2008 in the Eastern Pyrenees. Natural Hazard and Earth System Sciences, v. 10, p. 1635-1645, 2010

QUEIROZ NETO, J. P.; OLIVEIRA, J. B. (1964). Solos do Litoral. Instituto Agronômico de Campinas.

QUINN, P.; BEVEN, K.; CHEVALLIER, P.; PLANCHON, Q. The prediction of hillslope flow paths for distributed hydrological modeling using Digital Terrain Models. Hydrological Processes, vol. 5, p. 59-79, 1991

REID, L. M.; PAGE, M. J. Magnitude and frequency of landsliding in a large New Zealand catchment. Geomorphology, v. 49, p. 71/88, 2002

RICkENMANN, D.; ZIMMERMANN, M. The 1987 debris flows in Switzerland: documentation and analysis. Geomorphology, v.8, p. 175-189, 1993

RICKENMANN, D. Empirical relationships for debris flows. Natural Hazards, v. 19, p. 47-77, 1999

RICKENMANN, D.; WEBER, D.; STEPANOV, B. (2003). Erosion by debris flows in field and laboratory experiments. In: Rickenmann D, Chen C (eds) Proceedings of 3rd Int. Conf. on Debris-Flow Hazards Mitigation. Millpress, Davos, pp 883- 894

RITTER, D. F.; KOCHEL, R. C.; MILLER, J. R. Process Geomorphology. Dubuque: Ed. William C. Brown Pub., p. 546, 1955

RODICA, J.; DIRJA, M.; BADESCU, G.; HOBLE, A. Drainage density by spatial analysis. Agriculture - Science and Practice, v. 1(2), p. 180-184, 2014

ROGELIS, M. C.; WERNER, M. Regional debris flow susceptibility analysis in mountains peri-urban areas through morphometric and land cover indicators. Natural Hazards and Earth system Sciences, v. 14, p. 3043-3064, 2014

ROOD, K. M. An aerial photograph inventory of the frequency and yield of mass wasting on the Queen Charlotte Islands, British Columbia. BC Ministry of Forests, Land Management Report, 34, p. 65, 1984

ROSIM, S; MONTEIRO, A. M. V.; RENNO, C.M.; SOUZA, R. C. M.; SOARES, J. V. TerraHidro - Uma plataforma computacional para o desenvolvimento de aplicativos para a análise integrada de recursos hídricos. In: Simpósio Brasileiro de Sensoriamento Remoto, XI, 2003, Belo Horizonte. Anais do Simpósio Brasileiro de Sensoriamento Remoto, Belo Horizonte, 2003, p. 2589-2596

ROSIM, S.; MONTEIRO, A. M. V.; RENNO, C. D.; OLIVEIRA, J. R. F. Uma ferramenta open source que unifica representações de fluxo local para apoio à gestão de recursos hídricos no Brasil. Informática Pública, v. n. 1, p. 29-49, 2008

ROSIM, S.; OLIVEIRA, J. R. F.; JARDIM, A. C.; NAMIKAWA, L. B.; RENNO, C. D. TerraHidro: A distributed hydrology modelling system with high quality drainage extraction. In: The Fifth International Conference on Advanced Geographic 
Information Systems, Applications, and Services, Nice, França. GEOProcessing 2013, Nice, França, 2013, p. 161-167

ROSS, J. L. S.; MOROZ, I. C. Mapa Geomorfológico do Estado de São Paulo. Laboratório de Geomorfologia. São Paulo: Departamento de Geografia - FFLCH USP/Laboratório de Cartografia Geotécnica - Geologia Aplicada - IPT/FAPESP (Fundação do Amparo à Pesquisa do Estado de São Paulo), 1997. (Mapas e Relatórios)

SAKAI, R. O. Estudo do impacto de debris flows: caso da bacia do rio Santo Antônio em Caraguatatuba (Brasil) (2014). p. 236. Dissertação (Mestrado em Engenharia) - Escola Politécnica, Universidade de São Paulo, São Paulo, 2014.

SALVADOR, E. D. Roteiro para geração de carta de drenagens e delimitação de bacias hidrográficas a partir de MNT no ArcGis 9.X. São Paulo: CPRM, 2007, p. 9

SANTI, P. M.; DE WOLFE, V. G.; HIGGINS, J. D.; CANNON, S. H.; GARTNER, J. E. Sources of debris flow material in burned areas. Geomorphology, 96, p. 310-321, 2008)

SANTOS, L. C. S.; FRANCISCO, C. N. Avaliação dos Modelos Digitais de Elevação aplicados à extração automática de redes de drenagem. In: Simpósio Brasileiro de Sensoriamento Remoto - SBSR, XV, 2011, Curitiba. Anais do Simpósio Brasileiro de Sensoriamento Remoto, Curitiba, 2011, p. 1311-1318

SANTOS, D. D.; GALVANI, E. Caracterização sazonal das precipitações no município de Caraguatatuba - SP, entre os anos de 1943 a 2004. Revista GEONORTE, Edição Especial 2, vol. 1, n5, p. 1196-1203, 2012.

SANT'ANNA NETO, J. L. Dinâmica Atmosférica e o Caráter Transicional do Clima na Zona Costeira Paulista. Revista do Departamento de Geografia (USP), São Paulo, v. 8, p. 35-49, 1994.

SARMA, P. K.; SARMAH, K.; CHETRI, P. K.; SARKAR, A. Geospatial study on morphometric characterization of Umtrev river basin of Meghalaya, India. International Journal of Water Resources and Environmental Engineering, v. 5 (8), p. 489-498, 2013

SCALLY, F.; SLAYMAKER, O.; OWENS, I. Morphometric controls and basin response in the Cascade mountains. Geografiska Annaler, vol. 83, p. 117-130, 2001

SCHUMM, S.A. Evolution of drainage systems and slopes in badlands at Perth Amboy, New Jersey. Bulletin of the Geological Society of America, vol. 67, p. 597-646, 1956

SELUCHI, M. E.; CHOU, S. C. Synoptic patterns associated with landslide events in the Serra do Mar, Brazil. Theoretical and Applied Climatology, v. 98, p. 67-77, 2009

SESTINI, M. F.; FLORENZANO, T. G. Caracterização de cicatrizes de deslizamentos por processamento de dados TM Landsat em Caraguatatuba-SP. São Paulo, USP, Geol. USP Sér. Cient. v.4, n.2, p. 57-69, outubro de 2004 
SHAHABI, H.; AHMAD, B. B.; KHEZRI, S. Landslide susceptibility mapping using Image Satellite and GIS technology. International Journal of Engineering Research \& Technology, v. 1 (6), p. 5, 2012

SIDLE, R. C.; PEARCE A. J.; O'LOUGHLIN C. L. Hillslope stability and land use. Washington, D. C.: Water resources monograph series (11), p. 140, 1985.

SILVA, J. S.; LEITE, E. P. F.; GADELHA, A. G. Utilização de software livre na extração de atributos hidrológicos. In: Simpósio Brasileiro de Ciências Geodésicas e Tecnologias da Geoinformação, III, 2010, Recife. Anais...Recife: SBCGTG, 2010. p. 01-09

SILVEIRA, C. T.; FIORI, A. P.; FERREIRA, A. M.; GÓIS, J. R.; DE MIO, G.; SILVEIRA, R. M. P.; MASSULINI, N. E. B.; LEONARDI, T. M. H. Emprego de atributos topográficos no mapeamento da susceptibilidade a processos geoambientais na bacia do rio Jacareí, Paraná. Revista Sociedade e Natureza, vol. 25 (3), p. 623-639, 2013

SLAYMAKER, $O$. The distinctive attributes of debirs torrents. Hydrological Sciences, v. 33 (6), p. 567-573, 1988

SMALL, R. J. The study of landforms: a textbook of geomorphology. Cambridge University Press, 1970. p.486.

SORENSEN, R.; ZINKO, U.; SEIBERT, J. On the calculation of the topographic wetness index: evaluation of different methods based on field observations. Hydrology an Earth System Sciences, v. 10, p. 101-112, 2006

SOUZA, J. O. P.; ALMEIDA, J. D. M. Modelo digital de elevação e extração automática de drenagem: dados, métodos e precisão para estudos hidrológicos e geomorfológicos. Boletim de Geografia, Maringá, v. 32 (2), p. 134-149, 2014

STERNBERG, H. O. Enchentes e movimentos coletivos do solo no Vale do Paraíba em dezembro de 1948 - Influência da exploração destrutiva das terras. Revista Brasileira de Geografia 11 (2), p. 223-261, 1979

TAKAHASHI, T. Estimation of potential debris flows and their hazardous zones: soft countermeasures for a disaster. Journal of Natural Disaster Science, vol. $3, n^{\circ} 1$, p. 57-89, 1981.

TAKAHASHI, T. Debris flow. Rotterdam; Brookfield Published for the International Association for Hydraulic Research by A.A. Balkema: 1991, p. 164

TANG, C.; RENGERS, N.; VAN ASCH, TH. W. J.; YANG, Y. H.; WANG, G. F. Triggering conditions and depositional characteristics of a disastrous debris flow event in Zhouqu city, Gansu Province, northwestern China. Natural Hazards and Earth system Sciences, v. 11, p. 2903-2912, 2011

TAVARES, R.; SANT'ANNA NETO, J. L.; TOMMASSELLI, J. T. G.; PRESSINOTTI, M. M. N.; SANTORO, J. Análise da variabilidade temporal e espacial das chuvas associada aos movimentos de massa no Litoral Norte Paulista. In: Simpósio Brasileiro de Desastres Naturais, 1., 2004, Florianópolis. Anais... Florianópolis: GEND/UFSC, 2004. p. 680-696. (CD ROM)

TIE, Y. Topographic features of debris flows gullies in Moxi basin, southwestern of China. Journal of Geoscience and Environment Protection, v. 2, p. 27-34, 2014 
TOMINAGA, L. K. Avaliação de metodologias de análise de risco a escorregamentos: Aplicação de um ensaio em Ubatuba, SP. (2007). p. 207. Tese (Doutorado em Geografia) - Faculdade de Filosofia, Letras e Ciências Humanas, Universidade de São Paulo, São Paulo, 2007

UEHARA, K.; HISHITANI, H.; TESUKA, Y.; MASSAD, F.; KANJI, M. A.; CRUZ, P. T.; FILHO, H. A. A. Environment effects os debris flows in Cubatão, São Paulo, Brazil. In: Symposium Brazil-Japan 2008 in Economy, Science and Techonological Innovation, 2008, São Paulo. Anais...São Paulo: SBPNA: Associação Brasil-Japão de Pesquisadores, 2008, p. 6 (CD-ROM)

VANDINE, D. F. Debris flows and debris torrents in the Southern Canadian Cordillera. Canadian Geotechnical Journal, v. 22, p. 44-68, 1985

VANDINE, D. F. Debris flow control structures for forest engineering. Res. Br., B. C. Min. For., Victoria, B. C., Work, Pap. 08/1996, p. 75, 1996

VAN STEIJN, H. Debris-flow magnitude-frequency relationships for mountainous regions of Central and Northwest Europe. Geomorphology, v. 15, p. 259-273, 1996

VAN WESTEN, C. J. Application of Geographic Information System to Landslide Hazard Zonation. Enschede, The Netherlands: ITC Publication, 1993. p. 245.

WECHSLER, S. P. Uncertainties associated with digital elevation models for hydrologic applications: a review. Hydrological Earth System Sciences, v. 11, p. 1481-1500, 2007

WIECZOREK, G. F. Effect of rainfall intensity and duration on debris flows in central Santa Cruz Mountains, California. Geological Society of America: Reviews in Engineering Geology, vol. 7, p. 93-104, 1987.

WILFORD, D. J.; SAKALS, M. E.; INNES, J. L.; SIDLE, R. C.; BERGERUD, W. A. Recognition of debris flow, debris flood and flood hazard through watershed morphometrics. Landslides, vol. 1, p. 61-66, 2004

WILSON, J. P.; GALLANT, J. C.(2000). Digital Terrain Analysis. In: Wilson, J. P.; Gallant, J.C. (Eds), Terrain Analysis: Principles and Aplication. John Wiley \& Sons, New York, p. 1-27

WOLLE, C. M.; CARVALHO, C. S. Taludes Naturais. In: FALCONI, F. F.; JUNIOR, A. N. (Org.), Solos do Litoral de São Paulo. São Paulo: ABMS, 1994. p. 180-203.

WRACHIEN, D.; MAMBRETTI, S. Assessment of debris flow magnitude in small catchments of the Lombardy alps: the Val Gola case study. Agricultural Sciences, v. 2(1), p. 9-15, 2011

YILDIZ, O. An investigation of the effect of dranaige density on hydrologic response. Turkish Journal Engineering Environment Sciences. V. 28, p. 85-94, 2004

ZARUBA, Q.; MENCL, V. Landslides and their control. Amsterdam: Elsevier, 1976. p. 205.

ZNAMENSKY, D. V. Corridas de lama e detritos nas vertentes e calhas como processos de escoamento bifásico. In: Congresso Brasileiro de Mecânica dos Solos e Engenharia Geotécnica - COBRAMSEG, XVII, 2014, Goiânia. Anais do 
Congresso Brasileiro de Mecânica dos Solos e Engenharia Geotécnica, Goiânia, 2014, p. 21

ZIMMERMANN, M. Debris flows 1987 in Switzerland: geomorphological and meteorological aspects. Hydrology in Mountains Regions. II Artificial Reservoirs; Water and Slopes. (Proceedings of two Lausanne Symposia, August 1990): IAHSPubl. № 194,1990 


\section{APÊNDICES}

Apêndice 1: Número de escorregamentos e volume de sedimentos $\left(\mathrm{m}^{3}\right)$

\begin{tabular}{|c|c|c|c|c|c|c|}
\hline & \multicolumn{2}{|c|}{ Santo Antônio } & \multicolumn{2}{|c|}{ Mococa } & \multicolumn{2}{|c|}{ Guaxinduba } \\
\hline & Área $\left(\mathrm{m}^{2}\right)$ & Volume (50\%) & Área $\left(\mathrm{m}^{2}\right)$ & Volume (50\%) & Área $\left(\mathrm{m}^{2}\right)$ & Volume $(50 \%)$ \\
\hline 1 & 45,8 & 22,9 & 383,1 & 191,6 & 1250,3 & 625,1 \\
\hline 2 & 90,1 & 45,0 & 472,5 & 236,3 & 2271,1 & 1135,6 \\
\hline 3 & 384,1 & 192,1 & 661,1 & 330,6 & 2884,1 & 1442,1 \\
\hline 4 & 2123,1 & 1061,5 & 775,3 & 387,7 & 3343,6 & 1671,8 \\
\hline 5 & 2413,0 & 1206,5 & 779,5 & 389,8 & 3807,8 & 1903,9 \\
\hline 6 & 2420,9 & 1210,4 & 945,3 & 472,7 & 3878,7 & 1939,3 \\
\hline 7 & 2532,3 & 1266,1 & 947,5 & 473,8 & 4008,2 & 2004,1 \\
\hline 8 & 2819,1 & 1409,5 & 999,1 & 499,6 & 4058,1 & 2029,1 \\
\hline 9 & 2828,1 & 1414,1 & 1057,3 & 528,7 & 4201,5 & 2100,8 \\
\hline 10 & 2976,5 & 1488,2 & 1126,7 & 563,4 & 4750,9 & 2375,5 \\
\hline 11 & 3054,8 & 1527,4 & 1178,2 & 589,1 & 4824,8 & 2412,4 \\
\hline 12 & 3174,0 & 1587,0 & 1178,2 & 589,1 & 5701,1 & 2850,6 \\
\hline 13 & 3488,0 & 1744,0 & 1191,0 & 595,5 & 5732,3 & 2866,2 \\
\hline 14 & 3524,8 & 1762,4 & 1240,2 & 620,1 & 6111,6 & 3055,8 \\
\hline 15 & 3711,2 & 1855,6 & 1243,2 & 621,6 & 6246,3 & 3123,1 \\
\hline 16 & 3766,1 & 1883,1 & 1280,2 & 640,1 & 6442,3 & 3221,1 \\
\hline 17 & 3832,1 & 1916,0 & 1317,2 & 658,6 & 6681,0 & 3340,5 \\
\hline 18 & 3931,7 & 1965,8 & 1333,2 & 666,6 & 6757,1 & 3378,5 \\
\hline 19 & 4141,0 & 2070,5 & 1337,1 & 668,6 & 6882,1 & 3441,1 \\
\hline 20 & 4311,1 & 2155,5 & 1467,3 & 733,7 & 6904,8 & 3452,4 \\
\hline 21 & 4347,6 & 2173,8 & 1491,9 & 746,0 & 7260,7 & 3630,3 \\
\hline 22 & 4415,5 & 2207,8 & 1512,1 & 756,1 & 7349,7 & 3674,8 \\
\hline 23 & 4420,8 & 2210,4 & 1552,4 & 776,2 & 7715,4 & 3857,7 \\
\hline 24 & 5049,4 & 2524,7 & 1630,8 & 815,4 & 7805,2 & 3902,6 \\
\hline 25 & 5058,7 & 2529,3 & 1680,1 & 840,1 & 7894,7 & 3947,4 \\
\hline 26 & 5082,2 & 2541,1 & 1769,7 & 884,9 & 7923,4 & 3961,7 \\
\hline 27 & 5188,0 & 2594,0 & 1879,6 & 939,8 & 8595,3 & 4297,7 \\
\hline 28 & 5463,0 & 2731,5 & 1917,2 & 958,6 & 8802,9 & 4401,4 \\
\hline 29 & 5699,7 & 2849,9 & 1917,4 & 958,7 & 9555,0 & 4777,5 \\
\hline 30 & 5715,6 & 2857,8 & 1962,4 & 981,2 & 10342,9 & 5171,5 \\
\hline 31 & 5886,3 & 2943,2 & 2056,4 & 1028,2 & 10883,2 & 5441,6 \\
\hline 32 & 6038,5 & 3019,3 & 2063,1 & 1031,6 & 11184,8 & 5592,4 \\
\hline 33 & 6085,5 & 3042,8 & 2160,6 & 1080,3 & 11289,7 & 5644,9 \\
\hline 34 & 6148,5 & 3074,2 & 2400,9 & 1200,5 & 11443,6 & 5721,8 \\
\hline 35 & 6242,1 & 3121,0 & 2568,4 & 1284,2 & 11611,5 & 5805,8 \\
\hline
\end{tabular}




\begin{tabular}{|c|c|c|c|c|c|c|}
\hline & & & & & & Continuação \\
\hline 36 & 6310,2 & 3155,1 & 2730,7 & 1365,4 & 12441,5 & 6220,8 \\
\hline 37 & 6578,7 & 3289,3 & 2903,2 & 1451,6 & 12591,7 & 6295,8 \\
\hline 38 & 6604,7 & 3302,3 & 3073,6 & 1536,8 & 12945,8 & 6472,9 \\
\hline 39 & 6620,7 & 3310,4 & 3186,3 & 1593,2 & 15346,8 & 7673,4 \\
\hline 40 & 6816,7 & 3408,3 & 3259,4 & 1629,7 & 15533,9 & 7766,9 \\
\hline 41 & 6902,0 & 3451,0 & 3423,6 & 1711,8 & 16196,6 & 8098,3 \\
\hline 42 & 7074,9 & 3537,5 & 3740,4 & 1870,2 & 17221,7 & 8610,9 \\
\hline 43 & 7084,4 & 3542,2 & 3804,7 & 1902,4 & 18484,0 & 9242,0 \\
\hline 44 & 7229,2 & 3614,6 & 4062,7 & 2031,4 & 19054,1 & 9527,0 \\
\hline 45 & 7437,3 & 3718,7 & 4178,4 & 2089,2 & 19407,3 & 9703,6 \\
\hline 46 & 7443,0 & 3721,5 & 4557,4 & 2278,7 & 20432,1 & 10216,1 \\
\hline 47 & 7524,3 & 3762,1 & 4662,3 & 2331,2 & 22548,0 & 11274,0 \\
\hline 48 & 7603,9 & 3801,9 & 4996,4 & 2498,2 & 30102,5 & 15051,2 \\
\hline 49 & 7628,8 & 3814,4 & 5035,4 & 2517,7 & 36684,6 & 18342,3 \\
\hline 50 & 7771,6 & 3885,8 & 5233,7 & 2616,9 & 48060,3 & 24030,1 \\
\hline 51 & 7893,7 & 3946,9 & 5262,1 & 2631,1 & 94064,9 & 47032,5 \\
\hline 52 & 8236,5 & 4118,2 & 5630,1 & 2815,1 & - & - \\
\hline 53 & 8444,6 & 4222,3 & 5841,2 & 2920,6 & - & - \\
\hline 54 & 8612,1 & 4306,0 & 6085,8 & 3042,9 & - & - \\
\hline 55 & 8778,6 & 4389,3 & 6424,8 & 3212,4 & - & - \\
\hline 56 & 8957,9 & 4479,0 & 6435,9 & 3218,0 & - & - \\
\hline 57 & 9111,7 & 4555,9 & 6485,9 & 3243,0 & - & - \\
\hline 58 & 9134,8 & 4567,4 & 6519,3 & 3259,7 & - & - \\
\hline 59 & 9188,6 & 4594,3 & 6813,8 & 3406,9 & - & - \\
\hline 60 & 9243,7 & 4621,9 & 7175,1 & 3587,6 & - & - \\
\hline 61 & 9999,2 & 4999,6 & 7230,7 & 3615,4 & - & - \\
\hline 62 & 10394,4 & 5197,2 & 7911,1 & 3955,6 & - & - \\
\hline 63 & 10524,8 & 5262,4 & 7953,2 & 3976,6 & - & - \\
\hline 64 & 11062,3 & 5531,1 & 7981,0 & 3990,5 & - & - \\
\hline 65 & 11122,4 & 5561,2 & 8303,4 & 4151,7 & - & - \\
\hline 66 & 11206,2 & 5603,1 & 9195,8 & 4597,9 & - & - \\
\hline 67 & 11238,3 & 5619,1 & 9576,1 & 4788,1 & - & - \\
\hline 68 & 11372,0 & 5686,0 & 11165,7 & 5582,9 & - & - \\
\hline 69 & 11678,0 & 5839,0 & 12074,6 & 6037,3 & & - \\
\hline 70 & 11700,7 & 5850,3 & 13317,3 & 6658,7 & - & - \\
\hline 71 & 11754,9 & 5877,4 & 13716,7 & 6858,4 & - & - \\
\hline 72 & 12124,9 & 6062,5 & 15007,3 & 7503,7 & - & - \\
\hline 73 & 12224,4 & 6112,2 & 22436,9 & 11218,5 & - & - \\
\hline 74 & 13497,5 & 6748,7 & 29111,9 & 14556,0 & - & - \\
\hline 75 & 13820,1 & 6910,1 & 68921,0 & 34460,5 & & - \\
\hline 76 & 15151,8 & 7575,9 & - & - & - & - \\
\hline 77 & 16006,7 & 8003,3 & - & - & - & - \\
\hline
\end{tabular}


Conclusão

\begin{tabular}{|c|c|c|c|c|c|c|}
\hline 78 & 16221,1 & 8110,6 & - & - & - & - \\
\hline 79 & 16300,7 & 8150,3 & - & - & - & - \\
\hline 80 & 16410,0 & 8205,0 & - & - & - & - \\
\hline 81 & 16528,1 & 8264,0 & - & - & - & - \\
\hline 82 & 16760,9 & 8380,4 & - & & - & - \\
\hline 83 & 17678,6 & 8839,3 & - & - & - & - \\
\hline 84 & 17812,5 & 8906,2 & - & - & - & - \\
\hline 85 & 18072,5 & 9036,3 & - & - & - & - \\
\hline 86 & 18289,7 & 9144,8 & - & - & - & - \\
\hline 87 & 18749,6 & 9374,8 & - & - & - & - \\
\hline 88 & 19820,6 & 9910,3 & - & - & - & - \\
\hline 89 & 19831,6 & 9915,8 & - & - & - & - \\
\hline 90 & 19946,0 & 9973,0 & - & - & - & - \\
\hline 91 & 20793,4 & 10396,7 & - & - & - & - \\
\hline 92 & 23079,7 & 11539,9 & - & - & - & - \\
\hline 93 & 23119,8 & 11559,9 & - & - & - & - \\
\hline 94 & 24128,0 & 12064,0 & - & - & - & - \\
\hline 95 & 24228,0 & 12114,0 & - & - & - & - \\
\hline 96 & 24830,9 & 12415,5 & - & - & - & - \\
\hline 97 & 25125,0 & 12562,5 & - & - & - & - \\
\hline 98 & 26629,8 & 13314,9 & - & - & - & - \\
\hline 99 & 26834,1 & 13417,1 & - & - & - & - \\
\hline 100 & 26923,4 & 13461,7 & - & - & - & - \\
\hline 101 & 27415,5 & 13707,7 & - & - & - & - \\
\hline 102 & 28241,0 & 14120,5 & - & - & - & - \\
\hline 103 & 32907,4 & 16453,7 & - & - & - & - \\
\hline 104 & 33160,3 & 16580,2 & - & - & - & - \\
\hline 105 & 33796,2 & 16898,1 & - & - & - & - \\
\hline 106 & 94626,7 & 47313,4 & - & - & - & - \\
\hline Total & 1263781,1 & 631890,5 & 414901,1 & 207450,6 & 647511,3 & 323755,7 \\
\hline Média & 11922,5 & 5961,2 & 5532,0 & 2766,0 & 12696,3 & 6348,2 \\
\hline
\end{tabular}

O valor de $50 \%(0,5 \mathrm{~m})$ corresponde a espessura média das rupturas observadas na Serra do Mar em relação aos escorregamentos rasos $(1 \mathrm{~m})$ 
Apêndice 2: Parâmetros e índices das sub-bacias do rio Guaxinduba

\begin{tabular}{|c|c|c|c|c|c|c|c|}
\hline $\begin{array}{c}\text { Sub- } \\
\text { bacias }\end{array}$ & $\begin{array}{l}\text { Área } \\
\left(\mathrm{km}^{2}\right)\end{array}$ & Ampl.(m) & $\begin{array}{l}\text { Comp. total dos rios } \\
(\mathrm{km})\end{array}$ & $\begin{array}{l}\text { Comp. do rio } \\
\text { principal (km) }\end{array}$ & $\begin{array}{l}\text { Decl. Méd. do talvegue } \\
\text { principal }\left({ }^{\circ}\right)\end{array}$ & $\begin{array}{l}\text { Den. de Drenagem } \\
\left(\mathrm{km} / \mathrm{km}^{2}\right)\end{array}$ & $\begin{array}{c}\text { Í. de } \\
\text { circularidade }\end{array}$ \\
\hline 8 & 1.02 & 60 & 4.24 & 1.30 & 2.6 & 4.14 & 0.344 \\
\hline 18 & 0.09 & 90 & 0.32 & 0.32 & 3.6 & 3.56 & 0.582 \\
\hline 19 & 0.19 & 120 & 0.59 & 0.54 & 1.1 & 3.07 & 0.748 \\
\hline 21 & 1.01 & 220 & 3.62 & 2.21 & 3.4 & 3.57 & 0.472 \\
\hline 27 & 0.13 & 100 & 0.43 & 0.31 & 11.0 & 3.30 & 0.589 \\
\hline 29 & 0.08 & 90 & 0.36 & 0.36 & 12.4 & 4.81 & 0.513 \\
\hline 32 & 0.20 & 530 & 0.85 & 0.46 & 27.6 & 4.19 & 0.595 \\
\hline 36 & 0.18 & 570 & 0.92 & 0.83 & 24.6 & 5.18 & 0.372 \\
\hline 37 & 0.08 & 320 & 0.41 & 0.41 & 23.5 & 4.89 & 0.427 \\
\hline 38 & 0.10 & 590 & 0.67 & 0.67 & 16.7 & 6.71 & 0.235 \\
\hline 39 & 0.23 & 600 & 1.19 & 0.88 & 22.8 & 5.15 & 0.407 \\
\hline 40 & 0.08 & 300 & 0.35 & 0.35 & 20.4 & 4.55 & 0.576 \\
\hline 42 & 0.06 & 240 & 0.12 & 0.12 & 4.9 & 1.96 & 0.492 \\
\hline 43 & 0.08 & 280 & 0.38 & 0.38 & 16.3 & 4.50 & 0.503 \\
\hline 45 & 1.75 & 720 & 7.50 & 2.36 & 11.3 & 4.30 & 0.582 \\
\hline 47 & 0.68 & 360 & 2.77 & 1.13 & 9.6 & 4.10 & 0.332 \\
\hline 48 & 0.39 & 380 & 1.67 & 0.93 & 9.2 & 4.24 & 0.562 \\
\hline 54 & 0.94 & 460 & 3.83 & 1.43 & 11.4 & 4.09 & 0.516 \\
\hline 58 & 0.10 & 320 & 0.48 & 0.48 & 16.1 & 4.72 & 0.480 \\
\hline 63 & 0.10 & 330 & 0.41 & 0.41 & 16.2 & 4.03 & 0.476 \\
\hline
\end{tabular}


Apêndice 3: Parâmetros e modelos empíricos da vazão de pico e do volume total de sedimentos para as sub-bacias do rio Santo Antônio.

\begin{tabular}{|c|c|c|c|c|c|c|c|c|c|c|c|}
\hline \multirow{2}{*}{$\begin{array}{l}\text { Sub- } \\
\text { Bacia }\end{array}$} & \multirow{2}{*}{$\begin{array}{l}\text { Área } \\
\left(\mathrm{km}^{2}\right)\end{array}$} & \multirow[b]{2}{*}{ Ampl. (m) } & \multirow{2}{*}{$\begin{array}{c}\text { C. Principal } \\
(\mathbf{k m})\end{array}$} & \multicolumn{4}{|c|}{ Massad et al. (1997) } & \multicolumn{4}{|c|}{ Araya Moya (1994) } \\
\hline & & & & $\begin{array}{l}\mathrm{VP}(60 \\
\mathrm{mm} / \mathrm{h})\end{array}$ & $\begin{array}{c}\text { VP (100 } \\
\mathrm{mm} / \mathrm{h})\end{array}$ & $\begin{array}{l}\mathrm{VT}(60 \\
\mathrm{mm} / \mathrm{h})\end{array}$ & $\begin{array}{l}\text { VT (100 } \\
\mathrm{mm} / \mathrm{h})\end{array}$ & $\begin{array}{l}\text { VP. (60 } \\
\mathrm{mm} / \mathrm{h})\end{array}$ & $\begin{array}{l}\mathrm{VP}(100 \\
\mathrm{mm} / \mathrm{h})\end{array}$ & $\begin{array}{l}\mathrm{VT}(60 \\
\mathrm{mm} / \mathrm{h})\end{array}$ & $\begin{array}{l}\mathrm{VT}(100 \\
\mathrm{mm} / \mathrm{h})\end{array}$ \\
\hline 8 & 0,35 & 10 & 1,33 & 83 & 138 & 41591 & 69318 & 65 & 108 & 32528 & 54213 \\
\hline 4 & 0,60 & 310 & 1,49 & 143 & 238 & 71579 & 119298 & 201 & 335 & 100550 & 167584 \\
\hline 3 & 0,70 & 380 & 2,73 & 167 & 278 & 83509 & 139182 & 171 & 286 & 85881 & 143135 \\
\hline 7 & 2,36 & 340 & 2,96 & 565 & 942 & 282788 & 471314 & 542 & 905 & 271454 & 452423 \\
\hline 9 & 2,86 & 570 & 2,61 & 686 & 1143 & 343124 & 571873 & 782 & 1304 & 391216 & 652026 \\
\hline 5 & 3,91 & 750 & 3,66 & 938 & 1564 & 469377 & 782295 & 925 & 1542 & 462747 & 771245 \\
\hline 2 & 10,98 & 790 & 8,22 & 2634 & 4390 & 1317273 & 2195456 & 1641 & 2736 & 820803 & 1368005 \\
\hline 1 & 13,80 & 810 & 8,26 & 3312 & 5521 & 1656303 & 2760505 & 2067 & 3446 & 1033689 & 1722815 \\
\hline
\end{tabular}

Legenda: VP= vazão de pico $\left(\mathrm{m}^{3} / \mathrm{s}\right) ; \mathrm{VT}=$ volume total $\left(\mathrm{m}^{3}\right)$. 
Apêndice 4: Parâmetros e modelos empíricos da vazão de pico e do volume total de sedimentos para as sub-bacias do rio Guaxinduba.

\begin{tabular}{|c|c|c|c|c|c|c|c|c|c|c|c|}
\hline \multirow{2}{*}{$\begin{array}{l}\text { Sub- } \\
\text { Bacia }\end{array}$} & \multirow{2}{*}{$\begin{array}{l}\text { Área } \\
\left(\mathrm{km}^{2}\right)\end{array}$} & \multirow[b]{2}{*}{ Ampl. (m) } & \multirow{2}{*}{$\begin{array}{c}\text { C. Principal } \\
(\mathbf{k m})\end{array}$} & \multicolumn{4}{|c|}{ Massad et al. (1997) } & \multicolumn{4}{|c|}{ Araya Moya (1994) } \\
\hline & & & & $\begin{array}{l}\mathrm{VP}(60 \\
\mathrm{mm} / \mathrm{h})\end{array}$ & $\begin{array}{l}\text { VP (100 } \\
\mathrm{mm} / \mathrm{h})\end{array}$ & $\begin{array}{l}\mathrm{VT}(60 \\
\mathrm{mm} / \mathrm{h})\end{array}$ & $\begin{array}{l}\text { VT }(100 \\
\mathrm{mm} / \mathrm{h})\end{array}$ & $\begin{array}{l}\text { VP. }(60 \\
\mathrm{mm} / \mathrm{h})\end{array}$ & $\begin{array}{c}\mathrm{VP}(100 \\
\mathrm{mm} / \mathrm{h})\end{array}$ & $\begin{array}{l}\mathrm{VT}(60 \\
\mathrm{mm} / \mathrm{h})\end{array}$ & $\begin{array}{l}\mathrm{VT}(100 \\
\mathrm{mm} / \mathrm{h})\end{array}$ \\
\hline 42 & 0,06 & 240 & 0,12 & 15 & 24 & 7333 & 12223 & 86 & 143 & 42931 & 71553 \\
\hline 29 & 0,08 & 90 & 0,36 & 18 & 30 & 9054 & 15090 & 46 & 76 & 22790 & 37984 \\
\hline 40 & 0,08 & 300 & 0,35 & 18 & 31 & 9225 & 15375 & 60 & 100 & 29887 & 49813 \\
\hline 37 & 0,08 & 320 & 0,41 & 20 & 34 & 10057 & 16761 & 60 & 100 & 29902 & 49838 \\
\hline 43 & 0,08 & 280 & 0,38 & 20 & 34 & 10129 & 16882 & 62 & 103 & 30983 & 51640 \\
\hline 18 & 0,09 & 90 & 0,32 & 22 & 36 & 10865 & 18108 & 59 & 98 & 29335 & 48891 \\
\hline 38 & 0,10 & 590 & 0,67 & 24 & 40 & 11925 & 19875 & 60 & 101 & 30177 & 50296 \\
\hline 58 & 0,10 & 320 & 0,48 & 24 & 41 & 12196 & 20326 & 66 & 110 & 33038 & 55064 \\
\hline 63 & 0,10 & 330 & 0,41 & 24 & 41 & 12196 & 20326 & 73 & 122 & 36459 & 60765 \\
\hline 27 & 0,13 & 100 & 0,31 & 31 & 52 & 15589 & 25982 & 88 & 146 & 43932 & 73219 \\
\hline 36 & 0,18 & 570 & 0,83 & 42 & 71 & 21329 & 35548 & 94 & 157 & 47157 & 78595 \\
\hline 19 & 0,19 & 120 & 0,54 & 46 & 77 & 23157 & 38596 & 98 & 163 & 48988 & 81647 \\
\hline 32 & 0,20 & 530 & 0,46 & 48 & 81 & 24376 & 40626 & 150 & 250 & 74984 & 124973 \\
\hline 39 & 0,23 & 600 & 0,88 & 56 & 93 & 27752 & 46253 & 120 & 200 & 59908 & 99847 \\
\hline 48 & 0,39 & 380 & 0,93 & 95 & 158 & 47313 & 78855 & 182 & 303 & 91017 & 151695 \\
\hline 47 & 0,68 & 360 & 1,13 & 162 & 270 & 81112 & 135187 & 276 & 459 & 137831 & 229719 \\
\hline 54 & 0,94 & 460 & 1,43 & 225 & 374 & 112249 & 187082 & 347 & 579 & 173693 & 289489 \\
\hline 21 & 1,01 & 220 & 2,21 & 243 & 406 & 121732 & 202886 & 255 & 425 & 127398 & 212331 \\
\hline 8 & 1,02 & 60 & 1,30 & 246 & 409 & 122764 & 204607 & 273 & 456 & 136649 & 227748 \\
\hline 45 & 1,75 & 720 & 2,36 & 419 & 698 & 209408 & 349014 & 529 & 881 & 264422 & 440704 \\
\hline
\end{tabular}

Legenda: VP= vazão de pico $\left(\mathrm{m}^{3} / \mathrm{s}\right) ; \mathrm{VT}=\operatorname{volume}$ total $\left(\mathrm{m}^{3}\right)$. 
Apêndice 5: Parâmetros e modelos empíricos da vazão de pico e do volume total de sedimentos para as sub-bacias do rio Mococa.

\begin{tabular}{|c|c|c|c|c|c|c|c|c|c|c|c|}
\hline \multirow{2}{*}{$\begin{array}{l}\text { Sub- } \\
\text { Bacia }\end{array}$} & \multirow{2}{*}{$\begin{array}{l}\text { Área } \\
\left(\mathrm{km}^{2}\right)\end{array}$} & \multirow{2}{*}{$\begin{array}{l}\text { Ampl. } \\
\text { (m) }\end{array}$} & \multirow{2}{*}{$\begin{array}{c}\text { C. Principal } \\
(\mathbf{k m})\end{array}$} & \multicolumn{4}{|c|}{ Massad et al. (1997) } & \multicolumn{4}{|c|}{ Araya Moya (1994) } \\
\hline & & & & $\begin{array}{l}\mathrm{VP}(60 \\
\mathrm{mm} / \mathrm{h})\end{array}$ & $\begin{array}{l}\mathrm{VP}(100 \\
\mathrm{mm} / \mathrm{h})\end{array}$ & $\begin{array}{l}\mathrm{VT}(60 \\
\mathrm{mm} / \mathrm{h})\end{array}$ & $\begin{array}{l}\text { VT (100 } \\
\mathrm{mm} / \mathrm{h})\end{array}$ & $\begin{array}{l}\mathrm{VP} .(60 \\
\mathrm{mm} / \mathrm{h})\end{array}$ & $\begin{array}{l}\mathrm{VP}(100 \\
\mathrm{mm} / \mathrm{h})\end{array}$ & $\begin{array}{l}\text { VT (60 } \\
\mathrm{mm} / \mathrm{h})\end{array}$ & $\begin{array}{c}\mathrm{VT}(100 \\
\mathrm{mm} / \mathrm{h})\end{array}$ \\
\hline 33 & 0,12 & 430 & 0,55 & 29 & 489 & 14652 & 24420 & 78 & 130 & 38947 & 64911 \\
\hline 22 & 0,14 & 340 & 0,42 & 334 & 56 & 16785 & 27975 & 100 & 166 & 49820 & 83034 \\
\hline 21 & 0,18 & 600 & 0,77 & 42 & 70 & 21035 & 35058 & 99 & 164 & 49262 & 82104 \\
\hline 17 & 0,24 & 370 & 0,80 & 57 & 95 & 28538 & 47563 & 119 & 198 & 59355 & 98925 \\
\hline 14 & 0,33 & 510 & 1,23 & 80 & 134 & 40186 & 66976 & 138 & 231 & 69237 & 115395 \\
\hline 13 & 0,41 & 570 & 1,17 & 99 & 165 & 49478 & 82463 & 179 & 299 & 89747 & 149578 \\
\hline 9 & 1,37 & 560 & 2,76 & 328 & 547 & 164211 & 273686 & 361 & 602 & 180587 & 300979 \\
\hline 7 & 1,93 & 770 & 2,44 & 464 & 774 & 232188 & 386979 & 582 & 970 & 290858 & 484764 \\
\hline 6 & 2,28 & 600 & 3,47 & 547 & 912 & 273484 & 455807 & 533 & 888 & 266468 & 444114 \\
\hline 5 & 2,86 & 730 & 3,82 & 688 & 1146 & 343772 & 572954 & 658 & 1097 & 329265 & 548775 \\
\hline 4 & 2,94 & 620 & 4,53 & 707 & 1178 & 353283 & 588806 & 594 & 990 & 297016 & 495027 \\
\hline 3 & 4,12 & 860 & 4,27 & 989 & 1649 & 494733 & 824555 & 915 & 1526 & 457769 & 762948 \\
\hline
\end{tabular}

Legenda: VP= vazão de pico $\left(\mathrm{m}^{3} / \mathrm{s}\right) ; \mathrm{VT}=$ volume total $\left(\mathrm{m}^{3}\right)$ 